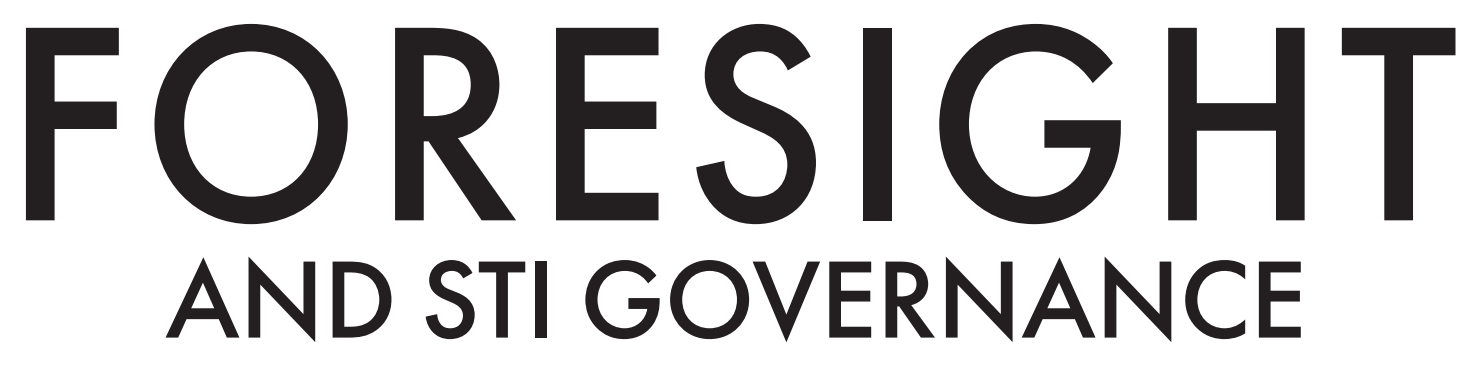

JOURNAL OF THE NATIONAL RESEARCH UNIVERSITY HIGHER SCHOOL OF ECONOMICS

ISSN 2500-2597

2017

Vol.11 No 3

(B)

SPECIAL ISSUE

INNOVATION ENTREPRENEURSHIP IN TRANSFORMATION ECONOMIES

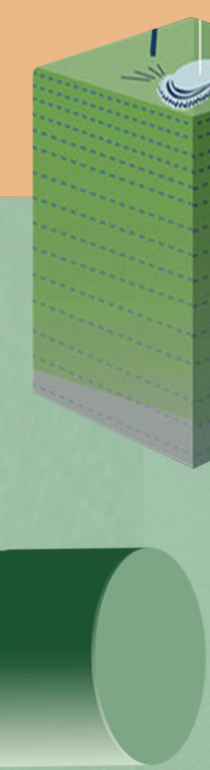




\section{FORESIGHT AND STI GOVERNANCE}

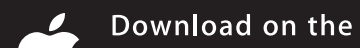 App Store}
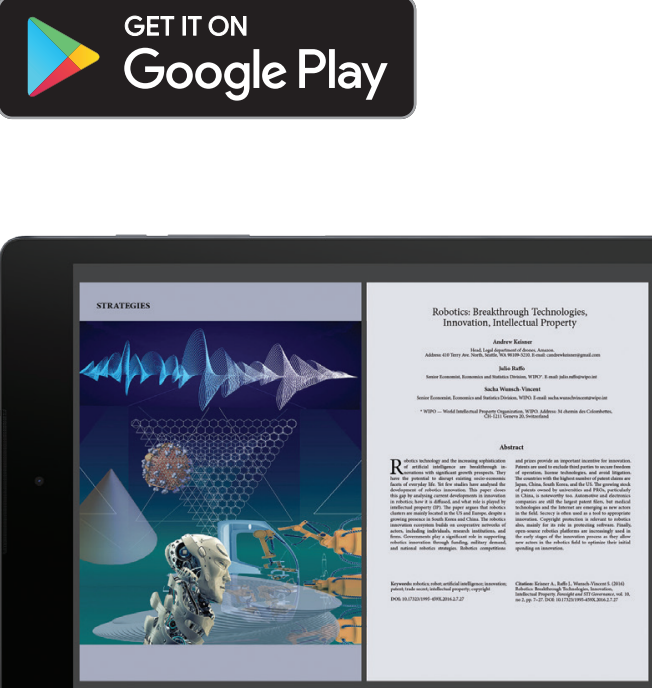


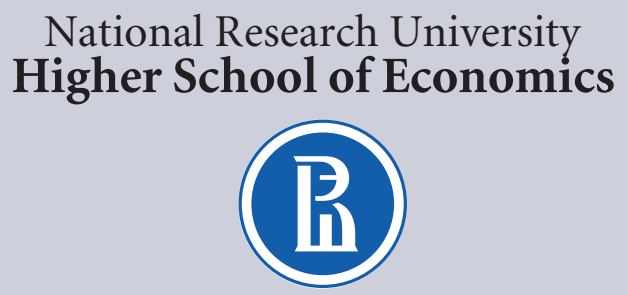

Institute for Statistical Studies and Economics of Knowledge

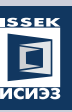

Editor-in-Chief — Leonid Gokhberg, First Vice-Rector, HSE, and Director, ISSEK, HSE, Russian Federation

Deputy Editor-in-Chief - Alexander Sokolov, HSE, Russian Federation

\section{EDITORIAL BOARD}

Tatiana Kuznetsova, HSE, Russian Federation Dirk Meissner, HSE, Russian Federation Yury Simachev, HSE, Russian Federation Thomas Thurner, HSE, Russian Federation, and University of Cape Town, South Africa

Executive Editor - Marina Boykova Development Manager - Nataliya Gavrilicheva Literary Editors - Yakov Okhonko, Caitlin Montgomery Proofreaders - Ekaterina Malevannaya, Designer - Mariya Salzmann

Layout - Mikhail Salazkin

\section{Address:}

National Research University Higher School of Economics 20, Myasnitskaya str., Moscow, 101000, Russia

Tel: +7 (495) 621-40-38

E-mail: foresight-journal@hse.ru

http://foresight-journal.hse.ru/en/

Periodicity - quarterly

ISSN 2500-2597

ISSN 2312-9972 (online)

ISSN 1995-459X (Russian print version)

\section{Publisher:}

National Research University

Higher School of Economics

(c) National Research University

Higher School of Economics, 2017

\section{EDITORIAL COUNCIL}

Igor Agamirzyan, HSE, Russian Federation Andrey Belousov, Administration of the President of the Russian Federation

Cristiano Cagnin, Center for Strategic Studies and Management (CGEE), Brasil

Elias Carayannis, George Washington University, United States

Mario Cervantes, Directorate for Science, Technology and Industry, OECD

Charles Edquist, Lund University, Sweden

Ted Fuller, University of Lincoln, UK

Luke Georghiou, University of Manchester, United Kingdom

Karel Haegeman, EU Joint Research Centre (JRC)

Attila Havas, Institute of Economics, Hungarian Academy of Sciences

Michael Keenan, Directorate for Science, Technology and Industry, OECD

Alexander Khlunov, Russian Science Foundation Andrey Klepach, Bank for Development and Foreign Economic Affairs, Russian Federation

Mikhail Kovalchuk, National Research Centre "Kurchatov Institute», Russian Federation

Yaroslav Kuzminov, HSE, Russian Federation

Carol S. Leonard, HSE, Russian Federation, and

University of Oxford, United Kingdom

Jonathan Linton, HSE, Russian Federation, and University of Sheffield, United Kingdom

Ian Miles, HSE, Russian Federation, and University of Manchester, United Kingdom

Rongping Mu, Institute of Policy and Management, Chinese Academy of Sciences

Fred Phillips, Yuan Ze University, Taoyuan, Taiwan

Wolfgang Polt, Joanneum Research, Austria

Ozcan Saritas, HSE, Russian Federation, and University of Manchester, United Kingdom

Klaus Schuch, Centre for Social Innovation, Austria

Nicholas Vonortas, HSE, Russian Federation, and George Washington University, United States

Angela Wilkinson, University of Oxford, United Kingdom 


\section{ABOUT THE JOURNAL}

Foresight and STI Governance (formerly Foresight-Russia) is an open access journal established by the National Research University Higher School of Economics (HSE) and administered by the HSE Institute for Statistical Studies and Economics of Knowledge (ISSEK), located in Moscow, Russia. The mission of the journal is to support the creation of Foresight culture through the dissemination of the best national and international practices of future-oriented innovation development. It also provides a framework for discussing S\&T trends and policies.

\section{TOPICAL COVERAGE:}

- Foresight methodologies

- Results of Foresight studies

- Long-term priorities for social, economic and S\&T development

- S\&T and innovation trends and indicators

- S\&T and innovation policies

- Strategic programmes of innovation development at national, regional, sectoral and corporate levels

- State-of-the-art methods and best practices of S\&T analysis and Foresight.

\section{TARGET AUDIENCE:}

Research scholars, university professors, policy-makers, businessmen, expert community, post-graduates, undergraduates and others who are interested in S\&T and innovation analyses, Foresight and policy issues.

The topical coverage of the journal makes it a unique Russian language title in its field. Foresight and STI Governance is published quarterly and distributed in Russia and abroad.

\section{INDEXING AND ABSTRACTING}

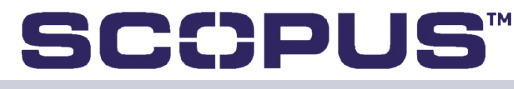

RUSSIAN SCENCECCITATION INDEX WEB OF SCIENCE

Scopus SJR Ranking - Q2 (since 2016)

Category: Business, Management and Accounting (miscellaneous)

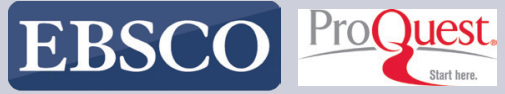

CLIBRARY.RU CYBERLENIIIKA

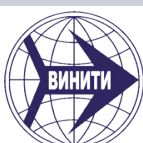

OAJI $\begin{aligned} & \text { Open Academic } \\ & \text { Journals Index }\end{aligned}$

(D) ULRICHSWEB"

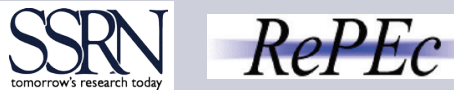




\section{CONTENTS}

\section{Vol. 11 No 32017}

\section{EDITORIAL}

6

Alexander Chepurenko

Innovation Enterpreneurship in Transition Economies: Problems and Outlook

PEOPLE'S ENTREPRENEURIAL ACTIVITY: SOURCES AND PATTERNS

11

Alexander Chepurenko

Entrepreneurial Activity in Post-Socialist Countries: Methodology and Research Limitations

Karina Bogatyreva, Galina Shirokova

From Entrepreneurial Aspirations to Founding a Business: The Case of Russian Students

37

Alina Sorgner

The Automation of Jobs: A Threat for Employment or a Source of New Entrepreneurial Opportunities?

\section{TECHNOLOGICAL ENTREPRENEURSHIP: FACTORS OF GROWTH}

\section{0}

Przemysław Zbierowski

The Aspirations of New Technology-Based Firms in CEE and CIS Countries

61

Elif Kalayci

Stakeholder Relationships in the Framework of R\&D-based Startups: Evidence from Turkey

\section{1}

Olga Obraztsova, Tatiana Poliakova, Ekaterina Popovskaya

The Choice of Funding Sources for Start-Ups in a Transitional Economy:

The Ability to Predict in a National Context

\section{INNOVATION IN COMPANIES}

83

Victoria Golikova, Boris Kuznetsov

Suboptimal Size: Factors Preventing the Growth of Russian Small and Medium-Sized Enterprises

94

Ian Miles, Veronika Belousova, Nikolay Chichkanov

Innovation Configurations in Knowledge-Intensive Business Services

103

Jana Hojnik, Mitja Ruzzier, Tatiana Manolova

Eco-Innovation and Firm Efficiency: Empirical Evidence from Slovenia 


\title{
Innovation Enterpreneurship in Transition Economies: Problems and Outlook
}

\author{
Alexander Chepurenko \\ Professor, Faculty of Social Sciences; and Head, Department of Economic Sociology, achepurenko@hse.ru
}

National Research University Higher School of Economics, 11, Myasnitskaya str., Moscow 101000, Russian Federation.

Citation: Chepurenko A. (2017) Innovation Enterpreneurship in Transition Economies: Problems and

Outlook. Foresight and STI Governance, vol. 11, no 3, pp. 6-9. DOI: 10.17323/2500-2597.2017.3.6.9

$\mathrm{T}$

his issue of the journal is dedicated to the various aspects of entrepreneurial development in countries with transitional economies. The specific features of entrepreneurship during the transition to a market economy are analyzed. Such features include the institutional environment that determines the socioeconomic and political contexts of entrepreneurial activities, sets the structure of incentives, and defines specific business strategies. In some cases, the relevant institutions' activities result in the emergence of predominantly productive entrepreneurship, in others, there are unproductive or even destructive processes [Baumol, 1990]. Thus, various national ecosystems are created, which affect innovation activities, labor markets, and people's involvement in entrepreneurship in a variety of ways.

Despite the fact that an impressive body of literature on the specific features of entrepreneurship in the former socialist countries has emerged over the past 20-25 years, a certain shortage of comparative empirical analysis still exists. This is due to the limited availability of reliable, representative data and a lack of validated concepts that might explain the increasingly divergent entrepreneurial ecosystem development paths for various former members of the so-called socialist bloc.

The papers in this issue advance a critical analysis of a popular thesis according to which the so-called "path dependence effect" is at the core of the country-specific evolution of entrepreneurial ecosystems in post-socialist nations. Over the course of the quarter of a century that has passed since the collapse of the socialist system in Central and Eastern European (CEE) countries and the former Soviet Union new opportunities have arisen there along with new institutional traps. They reflect the "design" of the systemic transformation, and describe the state of entrepreneurship in each of these countries. Furthermore, the authors confirm the argument that, in addition to the obvious differences in economic development levels, the state and the rate of entrepreneurial evolution in the countries under consideration are affected by numerous socio-cultural factors. As a consequence, countries with comparable per capita GDP figures may be very different in terms of their entrepreneurial development, or vice versa, they may be quite close to each other in this respect despite having significantly different general economic indicators.

Any entrepreneurial activity can be measured at the start-up stage, when potential challenges and opportunities are defined. The first group of papers in the issue analyze the sources of, reasons for, and patterns of entrepreneurial activity in the post-socialist region. The paper by Alexander Chepurenko "Entrepreneurial Activity in European Post-Socialist Countries: Methodology and Research Limits" considers approaches to classifying CEE countries into structurally and contextually defined groups. The paper analyzes the principles underlying such a taxonomy and proposes and justifies its new, original methodology. Two "axes" are put forward to typologize entrepreneurial ecosystems: the level of entrepreneurial activity and the quality of framework conditions for its development. The first indicator is determined by the motivational structure of entrepreneurship, and the second, by the difference between the share of nascent entrepreneurs, and that of people who ceased their 
business activities over the relevant period. Based on these two indicators measured by the Global Entrepreneurship Monitor (GEM), the paper identifies several clusters of CEE countries. Despite various limitations, this approach allows one to uncover empirically based differences between national entrepreneurship ecosystems and highlights the need to design government policies adapted to specific national contexts.

The paper by Karina Bogatyreva and Galina Shirokova analyzes the factors affecting the entrepreneurial activities of students, who due to their age and specific professional knowledge, have great potential to establish innovative entrepreneurial firms. On the basis of a sample comprising 32 Russian universities, the authors assess how factors like belonging to a business-owning family, support provided by the university entrepreneurial environment, and the level of development of the regional institutions affect the successful completion of the aspirations - to - start-up stage. The study is based on the planned behavior theory and the embeddedness perspective. It uses data from the Global University Entrepreneurial Spirit Students' Survey (GUESSS) conducted in 2013-2014. It was found that coming from a business-owning family tends to negatively affect potential entrepreneurs' probability of founding a start-up. On the contrary, there is a significant positive correlation between the level of development of the regional institutional environment for entrepreneurship and students' decision to set up a new venture. The pattern previously detected in advanced market economies was confirmed in the Russian context as well: without a smoothly operating regional entrepreneurial ecosystem, many aspirations to establish innovative start-ups simply cannot be realized. Accordingly, there is a need to review the interactions between key elements of the regional innovation process: start-up firms, intra-university innovation infrastructure, and the system of institutions responsible for promoting an innovation-based economy.

Alina Sorgner's paper is focused on the challenges faced by entrepreneurship due to the prospects for automation and the replacement of human labor at mass production facilities, which advanced economies will encounter as they move into the new technological paradigm. Various scenarios for employees who are going to lose their jobs due to automation are analyzed, such as becoming unemployed, changing professions, or becoming entrepreneurs. On the basis of data from the German longitudinal project, Socio-Economic Panel Data, the author concludes that representatives of more "secure" professions are more likely to opt for self-employment or establishing new companies than those whose jobs are likely to be cut. In other words, the overall growth of entrepreneurship will be achieved not due to necessity-driven entrepreneurs (i.e., those forced to make this choice by an unfavorable labor market situation), but rather by those motivated by the opportunities offered by new emerging technologies. However, this conclusion primarily applies to advanced market economies. In post-socialist countries where many framework conditions (ranging from the population's attitudes toward entrepreneurship to the actual institutional conditions for entrepreneurial activities) are distinctly different, the situation may therefore be quite different. An upsurge of necessity-driven entrepreneurship is quite probable there, similar to what happened at the beginning of the systemic transformation, however, this time it will be primarily caused not by social but technological trends. Confirming or refuting these hypotheses would require an analysis of the technological entrepreneurship segment in such countries, its specific features and development trends given that the degree of technological entrepreneurs' participation in the entrepreneurial ecosystem and the institutional maturity may significantly affect the prospects for the next wave of high-tech start-ups.

A special section of the journal, "Technological entrepreneurship: growth factors", is devoted to analyzing the aforementioned segments in developing economies. Przemysław Zbierowski's paper opens it. Based upon GEM data for 2013-2015 for Russia, Hungary, Romania, Poland, Lithuania, Latvia, Estonia, Czech Republic, and Kazakhstan, the author analyzes technological entrepreneurs' expectations and intentions regarding growth, entering external markets, and innovation strategies, furthermore he assesses their contribution to economic and social development. Radical differences were discovered between the above countries, both regarding the share of high-tech companies in the overall group of early entrepreneurs and in terms of expectations for growth, expansion to foreign markets, and innovation activities. Notably, Russia had the lowest values for almost all these indicators, while "leadership" is shared by several countries. Despite the limitations imposed by the GEM methodology, the results of the study allowed us to conclude that in the medium term, new high-tech companies' contributions to various transitional economies would probably be different, while the differences between country-specific aspects of entrepreneurship are likely to keep growing. Developing effective political recommendations will not be possible without taking the relevant national contexts into consideration. 
On the basis of case studies concerning technological entrepreneurship in Turkey, Elif Kalayc1 analyzes the development of networks between the founders of innovative start-up companies and their relevant potential stakeholders. The latter primarily includes family members and the government institutions responsible for supporting and promoting entrepreneurship. The author demonstrates that amid the specific socioeconomic conditions of a country like Turkey, family may significantly impede the development of innovative entrepreneurship. They might do so due to fears of the risks their relatives who decide to go into such businesses might face due to unstable institutional conditions. This observation can also be applied to post-socialist countries whose relevant framework conditions are similar to those of Turkey. The obvious contradictions between the mentality of employees (guided by causal considerations) and the effective logic of an entrepreneur can lead to the collapse of a start-up even at an early stage of its life cycle. Adopting an ethical and passionate approach to business from the very start helps bring an entrepreneur's social network into the circle of stakeholders supporting their project. The author's results partially contradict, but at the same time supplement the data previously published in the literature. The entrepreneur's family and the team they put together do not always serve as sources of help and support. Furthermore, in certain societal contexts, they can either stop the entrepreneur from launching the new venture or cause its failure. In such cases, having a sound basic idea and being able to involve members of one's social network in the business project become particularly important.

The paper by Olga Obraztsova, Tatiana Poliakova, and Ekaterina Popovskaya is devoted to an important issue: the assessment of the effects of various mechanisms for funding start-ups. In the majority of transitional economies, the entrepreneurs' own resources and so-called "love capital" (money provided by family or friends on non-market terms) serve as the main funding sources for start-up firms, which limits their opportunities for growth. In an attempt to find out what conditions would prompt early-stage entrepreneurs to more actively use borrowed resources, the authors analyzed a sample comprised of more than 2,000 observations made as part of the GEM project on the macroeconomic market parameters in Russia and six CEE countries. This paper demonstrates that, depending on the national context, different combinations of external factors and internal attitudes affect start-up entrepreneurs' ability to obtain funding from official sources. For example, in Croatia and Bosnia and Herzegovina such opportunities are significantly reduced due to related risks, which, on the other hand, are outweighed by highly innovative business ideas. This is also true for Latvia, where (as in Russia) favorable conditions for starting one's own business play a no less important, positive role. In Slovenia and Romania, the promotion of a positive image of entrepreneurship by the media is critically important. Post-socialist countries vary significantly not only in terms of their entrepreneurial activity, but also regarding the list and the nature of conditions that affect the available opportunities to borrow financial resources. Therefore, flexible national entrepreneurship promotion policies are needed. In some cases, promoting a more positive image of such activities in the media or increasing the financial and economic know-how of potential entrepreneurs seems to be enough, while in others systemic factors turn out to be more important, such as favorable conditions for establishing a new business or the innovativeness of the idea behind the start-up.

As companies mature, their links with the entrepreneurial ecosystem become more extensive and diverse. Specific features of this process in post-socialist countries are poorly understood. The materials presented in the third section, "Small and medium entrepreneurship", help one learn more about them. The chapter is opened by a paper by Victoria Golikova and Boris Kuznetsov, who assess external and internal factors limiting the growth of Russian small and medium firms. The data collected through an international survey of companies on the basis of a compatible methodology allowed the authors to conclude that compared with the EU, Russia has a higher share of small and medium production companies striving to step up the scale of their operations, but find they are unable to do so. The main reason is a lack of resources including skilled personnel, advanced equipment and extensive business networks. Insufficient access to external markets also hinders growth. The economic situation in the regions where the companies are located also plays a role: the higher the per capita GRP, the more satisfied companies are with the scale of their operations. Finally, the quality of the business climate matters as well (in particular, the level of corruption): only companies who know how to survive in an unfavorable environment can grow to the size they would consider sufficient. This may explain why Russia has fewer small and medium production companies able to successfully compete on the market compared with EU countries. A kind of vicious circle emerges: high administrative barriers result in higher transaction costs and smaller firms are more vulnerable to administrative pressure. The authors point out the institutional trap into which small production firms fall in regions where unstable or unfavorable framework 
conditions for entrepreneurship prevail. Therefore, without a qualitative change of the institutional environment, all measures to provide targeted support, including attempts to attract investments "manually", engaging private business in public procurement, etc., would not work. Thus, small and medium firms cannot create new high-quality jobs and innovations in the Russian and other similar economies.

The paper by Ian Miles, Veronika Belousova, and Nikolay Chichkanov analyzes the various innovation activities of companies providing knowledge-intensive business services. The study was based on data collected for 477 Russian companies belonging to this sector. Several clusters were identified: non-innovative companies, organizationally oriented innovators, marketingoriented innovators, technological innovators, non-technological innovators, and companies with a diversified innovative profile. The classification is based upon prevailing innovation types, the correlation between demand for knowledge-intensive services and customers' innovation activity level, and the degree of services' customization. The larger the company, the more diversified its innovation activities tend to be. And vice versa, smaller firms tend to be concentrated in the noninnovative cluster. This means that large-scale innovation activity requires financial stability, the application of advanced innovation management techniques, and other similar assets which small firms usually lack. At the same time, it is small and start-up companies that often create breakthrough innovations and advance social entrepreneurship.

Jana Hojnik, Mitja Ruzzier, and Tatiana Manolova studied the correlation between the application of various "green" innovations and firms' efficiency on the basis of data about more than 200 Slovenian companies. They established that the level of companies' innovation activity directly affects their inclination to use green technologies and make green products. Various eco-innovation types make different contributions to overall business efficiency: organizational innovations work well at all firms, while process innovations generate results only at more innovative companies. The results obtained by the authors suggest that companies should more actively use more advanced ecoinnovations. However, keeping in mind the conclusions arrived at by V. Golikova and B. Kuznetsov, this holds true for countries with successfully functioning entrepreneurial ecosystems. In other socioeconomic contexts, the growth of companies' productivity may be affected by other factors.

\section{References}

Baumol W.J. (1990) Entrepreneurship: Productive, Unproductive, and Destructive. Journal of Political Economy, vol. 98 , no 5, pp. 893-921. 


\section{PEOPLE'S ENTREPRENEURIAL ACTIVITY: SOURCES AND PATTERNS}

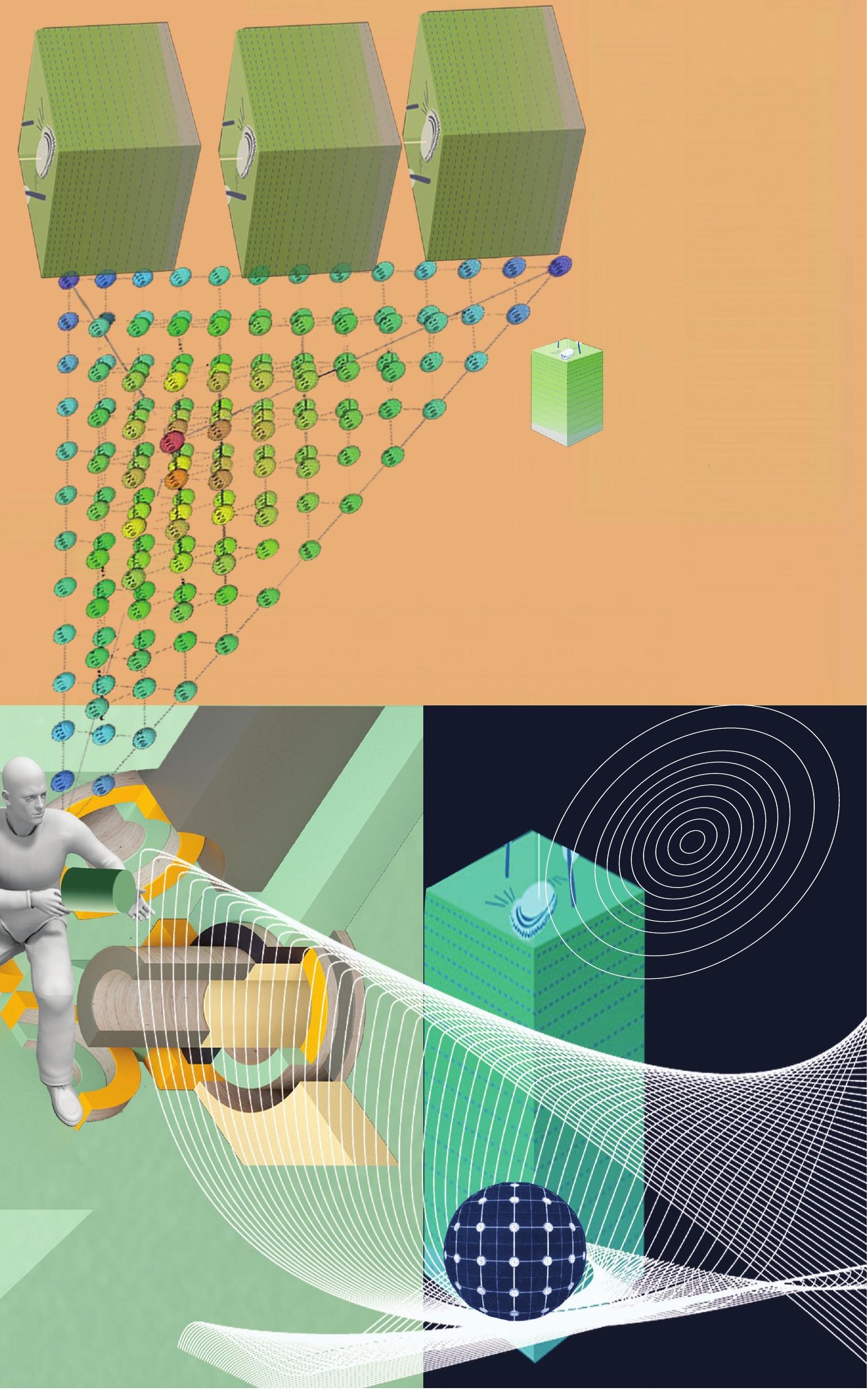




\title{
Entrepreneurial Activity in Post-Socialist Countries: Methodology and Research Limitations
}

\author{
Alexander Chepurenko \\ Professor, Faculty of Social Sciences; and Head, Department of Economic Sociology, achepurenko@hse.ru \\ National Research University Higher School of Economics, 11, Myasnitskaya str., Moscow 101000, Russian Federation.
}

\begin{abstract}
$\mathrm{T}$ The subject of this article is the entrepreneurial activity of the population residing in the post-socialist countries of Central and Eastern Europe (CEE), and its goal is to identify different types of ecosystems of entrepreneurship in these countries by means of analyzing entrepreneurial activity in various countries/groups of countries considered in the context of their societal and economic development. Empirically this article is based upon data from the Global Entrepreneurship Monitor (GEM). On the basis of an analysis of the strengths and weaknesses of existing approaches in the relevant literature to the taxonomy of business ecosystems, using a set of key country-level indicators of the GEM for 2011, this article proposes a taxonomy for entrepreneurship ecosystems
\end{abstract}

Abstract

\section{Keywords:}

entrepreneurship ecosystem;

entrepreneurial activity;

Central and Eastern Europe;

entrepreneurship theory. based on two «axes» - the quality of entrepreneurial activity (high, average, below average) and the state of the entrepreneurial framework conditions in the respective countries (favorable, average, below average). The result is a clustering of CEE countries' entrepreneurship ecosystems, where the worst cluster consists solely of Bosnia and Herzegovina, and the best contains the Czech Republic. Russia belongs to a cluster with mid-level indicators along both axes. The results might be used to implement a more focused policy promoting entrepreneurship and support for small businesses, which must move away from generalized schemes towards concrete policy concepts taking into account the resources and limitations of each of the selected types of entrepreneurship ecosystems.
Citation: Chepurenko A. (2017) Entrepreneurial Activity in Post-Socialist Countries: Methodology and Research Limitations. Foresight and STI Governance, vol. 11, no 3, pp. 11-24. DOI: 10.17323/2500-2597.2017.3.11.24 


\section{The emergence of entrepreneurship during the early stages of systemic transformation}

One of the major aims of the process of systemic transformation in the former Socialist countries in the late 1980s - early 1990s was the promotion of private entrepreneurship as a key tool for transitioning to a market economy [Kornai, 1992; Dallago, 1997; Blanchard, 1998; McMillan, Woodruff, 2002; et al.]. The international organizations that provided consulting and financial support for designing and establishing new institutions, along with the majority of national experts in Central and Eastern European (CEE) countries and the former USSR republics, assumed that entrepreneurship would emerge and become embedded in more or less the same forms, relying on similar legal principles and institutional prerequisites. All these factors were supposed to emerge along with the establishment of suitable socioeconomic conditions [Sachs, 1996; Gros, Steinherr, 2004] and the transfer of international experience, primarily that of the US and the EU.

The challenges entrepreneurs in the post-socialist countries faced during the initial stage of systemic transformation in most cases were common among them all [Kornai, 1992; Sachs, 1996; Johnson et al., 2000; Aidis, 2005a, 2005b]. However, by the mid to late 1990s, it became clear that these countries had split into two groups: transitional economies (i.e., those relatively successful in creating the conditions and prerequisites for the emergence of an entrepreneurial ecosystem) [Smallbone, Welter, 2002; et al.], and those that lagged in this process. The different levels of performance of said entrepreneurship ecosystems were mostly determined by their previous development experiences (path dependence).

It turned out that the average level of entrepreneurial dynamics in these countries was lower than expected at the early stage of the systemic transformation [Scase, 1997]. Moreover, experts noted that in most of these economies, privatization did not lead to the emergence of increased opportunities for new "Schumpeterian" entrepreneurship based on the formerly public assets [Kontovorich, 1999; Black et al., 2000; Earle, Sakova, 2000; Chilosi, 2001; Puffer, McCarthy, 2001; Manolova et al., 2008; Hashi, Krasniqi, 2011]. Furthermore, in many countries privatization in effect amounted to assets being seized by the former "nomenklatura" or by large multinational corporations supported by the new political elite. In other words, the phenomenon of so-called "predatory entrepreneurship" became a prominent feature of the initial stage of systemic transformation [Feige, 1997; Scase, 2003; Spicer et al., 2000].

Contrary to the large companies that emerged due to a "top-down" redistribution of formerly public assets between political entrepreneurs making use of their informal connections with decision-makers in many CIS countries [Boycko et al., 1997; Rehn, Taalas, 2004], the "bottom-up" spontaneous entrepreneurship, mostly represented by micro- and small businesses or solo entrepreneurs, had to rent the assets required to successfully operate their businesses from the state.

By the second half of the 1990s, it was generally accepted that countries transitioning to the new socioeconomic system were not homogeneous. Experts began to differentiate between the former Soviet republics, on the one hand, and the CEE and Baltic countries, on the other. After several of the latter were integrated into the EU, this division was accepted in the literature. A comparative analysis of the institutional environments and specific features of entrepreneurship in both groups of countries focused primarily on the following aspects (Table 1).

\section{From a common past to a different present}

By the early 2000s it became evident in the literature that the CEE and Baltic countries had achieved notable progress in their systemic transition to an entrepreneurial economy compared with the former republics - the members of the Commonwealth of Independent States (CIS) [Smallbone, Welter, 2002] ${ }^{1}$. Even in historically and geographically close countries, a basic indicator such as Total Early-Stage Entrepreneurial Activity (TEA) varies significantly (Figure 1).

Notably, the average TEA in post-socialist countries is higher than in the "older" EU member states. A possible explanation is the base effect: in such new market economies, market entry barriers and competition remain low, therefore it is easier to establish and run imitative (as opposed to innovative) businesses. It should be kept in mind that a significant part of entrepreneurial activity in post-socialist countries still is necessity-driven [Earle, Sakova, 2001] (Figure 2).

Compared with other EU economies covered by the GEM, the entrepreneurs in post-socialist countries have more modest ambitions regarding growth and new markets, preferring to do business on markets where they already are present; they do not try attract new groups of customers and consumers. However, there are certain differences in this regard as well (Figure 3).

\footnotetext{
More localized (geographically or in terms of foreign policy) clusters of post-social countries are also suggested, such as the Visegrad Group or the Black Sea Basin countries (including non-socialist Greece and Turkey). Some researchers also insist upon the need to view former the Yugoslav republics separately, given that Yugoslavia had market socialism as opposed to the planned, state-run economy [Szerb, Trumbull, 2015].
} 


\section{Table 1. Varying conditions for the development of entrepreneurship in CEE countries} and the former Soviet republics in the 1990s

\begin{tabular}{|c|c|c|}
\hline Factor & CEE countries & CIS countries \\
\hline \multirow{9}{*}{ Environment } & Association with Europe and EU countries & Dominance of old Soviet networks \\
\hline & $\begin{array}{l}\text { Western-oriented development, free market and } \\
\text { democracy as their declared goals }\end{array}$ & Mafia-style capitalist development, "crony capitalism" \\
\hline & Regulatory system of the EU (importing institutions) & $\begin{array}{l}\text { Regulatory system, taking into account best practices and the } \\
\text { countries' own developments (diffused institutes) }\end{array}$ \\
\hline & Stable and transparent institutions & No transparency, frequently changing institutions \\
\hline & $\begin{array}{l}\text { During socialist period, small and limited } \\
\text { private business culture survived }\end{array}$ & $\begin{array}{l}\text { During socialist period, private business culture was } \\
\text { completely eliminated }\end{array}$ \\
\hline & Memory of private businesses & No memory of private businesses \\
\hline & $\begin{array}{l}\text { Communism collapsed and resulted in a new political } \\
\text { elite }\end{array}$ & $\begin{array}{l}\text { Communism collapsed with only some change to the political } \\
\text { elite }\end{array}$ \\
\hline & Lack of financing & Lack of financing \\
\hline & Lower levels of corruption & Higher levels of corruption \\
\hline \multirow{2}{*}{ Role of the state } & Invisible hand model governing the market & Grabbing hand model: model of state distribution \\
\hline & Culture of cooperation and support & Culture of surveillance and inspections \\
\hline \multirow{6}{*}{$\begin{array}{l}\text { Business } \\
\text { owners' } \\
\text { characteristics }\end{array}$} & $\begin{array}{l}\text { Private businesses dominate economic activity, } \\
\text { stability is the main goal }\end{array}$ & $\begin{array}{l}\text { Business development focused on the 'big strike' or getting } \\
\text { rich quickly; coping with unstable market conditions }\end{array}$ \\
\hline & $\begin{array}{l}\text { Private businesses dominate economic activity, } \\
\text { stability is the main goal }\end{array}$ & Generic business activities \\
\hline & Diversified business sectors & Business activities primarily engaged in trade \\
\hline & Business development seen as a gradual process & $\begin{array}{l}\text { Part-time businesses in combination with employment in the } \\
\text { state sector }\end{array}$ \\
\hline & Individual businesses are the dominant form & Partnerships for business protection and survival predominate \\
\hline & Businesses function as part of an official economy & Businesses function in both official and informal economies \\
\hline
\end{tabular}

In some countries, the product-innovation TEA is more than twice as high as in some others: $17 \%$ in Slovenia vs. only $6 \%$ in Hungary. Regarding technological innovations the gap is even wider, all the way to sevenfold: $28 \%$ in the Czech Republic vs. only $3 \%$ in the neighboring Poland (both being fellow members of the Visegrad Group).

Therefore, in the academic literature on entrepreneurship in post-socialist countries, a gradual shift towards factors that might explain the above differences occurred. By the early 2000s, three relevant theories emerged in the literature. The first links the aforementioned diversity to the variability of initial institutional and societal matrices, which do not help (or even hinder) the development of entrepreneurship [Aidis, 2005b; Ovaska, Sobel, 2005; van der Zwan, 2011]. Authors in the second group concentrate on microlevel factors such as the individual characteristics of entrepreneurs in specific countries [McMillan, Woodruff, 2002; Cieslik, van Stel, 2012; Lafuente, Vaillant, 2013]. They stressed that there were not solely different attitudes towards entrepreneurship in society, but also various types of entrepreneurs with different motivations, goals and objectives, values, etc., prevailing in different transitional societies.

Finally, researchers in the third group insist on the need to take into account both institutional and specific individual features of the entrepreneurs [Estrin et al., 2006; Hashi, Krasniqi, 2011]. Following William Baumol [Baumol, 1990], they stress the differences between productive, non-productive, and destructive entrepreneurship [Kihlgren, 2003; Sauka, Welter, 2007], which combined with various

\section{Figure 1. Share of early-stage entrepreneurs in the working population of EU countries(\%)}

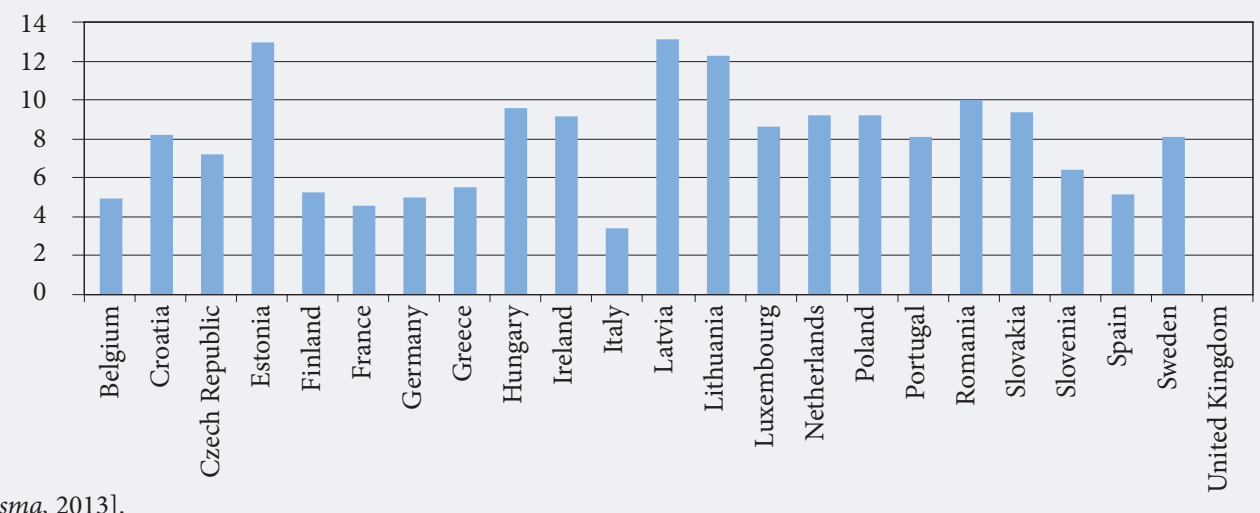


Figure 2. Shares of opportunity- and necessitydriven early-stage entrepreneurs among the economically active adult population of postsocialist European countries: 2001-2011 (\%)

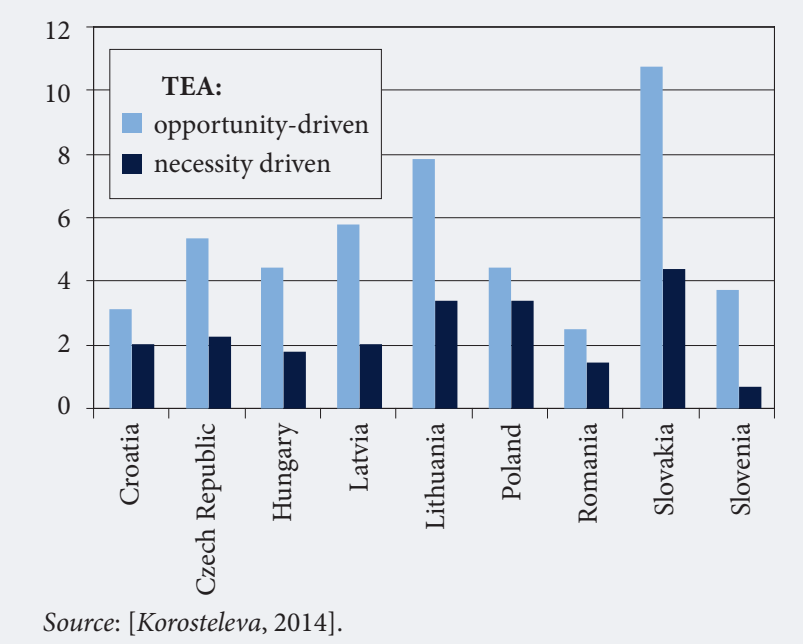

Figure 3. Structure of early-stage

entrepreneurship in post-socialist countries

by innovation type: average values for $2001-2011(\%)$

\begin{abstract}
institutional barriers creates different business habitats. Looking through such a lens, it becomes possible to identify different as well as some completely unique entrepreneurial ecosystems, comprising a small number of innovative companies with high growth potential and a mass of non-productive actors such as microenterprises, the self-employed (including those engaged in informal and shadow sectors of the economy), and businesses whose main resource is political rent (e.g., revenues generated through corruption, etc.) or even criminal violence [Smallbone, Welter, 2002; Volkov, 2012] (see Table 2). Not only do formal institutions whose development is monitored by international organizations and reflected in special indices (such as Doing Business ${ }^{2}$ etc.) play a role, informal ones do as well. These were noted by Saul Estrin and Tomasz Mickiewicz [Estrin, Mickiewicz, 2010] who among other things analyzed various attitudes, perceptions [Chepurenko, 2008], and social norms including trust [Raiser et al., 2003; Welter et. al., 2005].

Accession to the EU in 2004 and the rapid institutional development of eight CEE and Baltic countries (and, subsequently, three Balkan nations) resulted in increasingly different conditions for entrepreneurship there and in other transitional economies. This gap was due to the implementation of the framework principles of and approaches to providing support to entrepreneurship in the new EU member states, which permitted international organizations, to distinguish them from economies that do not meet the EU's requirements for business conditions and the development of the entrepreneurial environment. It is assumed by international organizations that the new EU members have completed their systemic transition [Kornai, 2006; Gros, Steinherr, 2004], while other countries are still moving towards that goal. In effect, geopolitical factors have become the criteria for classifying post-socialist countries.
\end{abstract}

\title{
Approaches to classifying entrepreneurial ecosystems: different approaches in the literature
}

An analysis of the framework conditions and entrepreneurial activities on the basis of Global Entrepreneurship Monitoring (GEM) data and various indices used by international organizations gives reason for doubting the relevance of such a geopolitically based approach to the typologization

\section{Table 2. Entrepreneur types based on motivation and source of revenues}

\begin{tabular}{|c|c|c|c|}
\hline & \multicolumn{3}{|c|}{ Entrepreneurship } \\
\hline & Productive & Non-productive & Destructive \\
\hline Necessity-driven & "Shuttles" & "Roofers" & "Raiders" \\
\hline $\begin{array}{l}\text { Opportunity- } \\
\text { driven }\end{array}$ & $\begin{array}{l}\text { Entrepreneurs/companies with high } \\
\text { growth potential ('gazelles') }\end{array}$ & Public and partially public monopolies & "Violent entrepreneurship" \\
\hline
\end{tabular}

Source: [Chepurenko, 2015]. 
Table 3. EFC quality and entrepreneurial activity indicators in post-socialist countries (based on the GEM data for 2011)

\begin{tabular}{|l|c|c|}
\hline \multicolumn{1}{|c|}{ Country } & $\left(\boldsymbol{T E A}_{\text {IDE }}-\boldsymbol{T E A}_{\text {nec }}\right): \boldsymbol{T E A}_{\text {mixed }}$ & $\left(\boldsymbol{B B O}-\boldsymbol{B U S}_{\text {disc }}\right)^{-1.3}$ \\
\hline Bosnia and Herzegovina & -2.329 & -1.3 \\
\hline Croatia & -0.135 & 1.7 \\
\hline Hungary & -0.045 & 2.5 \\
\hline Latvia & 0.728 & 3.8 \\
\hline Lithuania & 0.770 & 1.8 \\
\hline Poland & -2.110 & 1.7 \\
\hline Romania & -0.285 & 0.9 \\
\hline Russia & 0.481 & 2.2 \\
\hline Slovakia & 0.164 & 2.4 \\
\hline Czech Republic & 1.802 & 0.4 \\
\hline Slovenia & 1.065 & \\
\hline Source: $[$ Bosma et al., 2012]. & & \\
\hline
\end{tabular}

of post-socialist countries, at least as regards the ecosystems of entrepreneurship [Chepurenko, 2015; Szerb, Trumbull, 2015]. As Acs et al. said: "Because entrepreneurship researchers have focused on the individual and ignored the context, we have missed at least three important points: (1) that it is the context that regulates who decides to start a new firm; (2) it is the context that regulates what kind of firm they will start; (3) that the context also decides how aggressively the firm will pursue growth and with what outcomes" [Acs et al., 2016, p. 530]. In our opinion, obtaining a deeper and more precise understanding of the nature of entrepreneurship in post-socialist countries [Chepurenko, 2015] requires a deep immersion into the context of the various respective ecosystems, by studying the following areas:

- Context-dependent classification of transitioning societies and economies based upon an analysis of various institutional matrices and empirical data [Aidis et al., 2010a; Chepurenko et al., 2012; Estrin, Mickiewicz, 2010; Obraztsova, Chepurenko, 2010; Szerb, Trumbull, 2015; Welter, 2005; Welter, Smallbone, 2011b; et al.];

- An analysis of the effects of various types of interactions between networks, formal and informal institutions, and their impact on entrepreneurial behavior [Batjargal, 2006; Commander, Tolstopiatenko, 1997; Rehn, Taalas, 2004; et al.];

- Studying the variety and heterogeneity of productive, non-productive, and destructive entrepreneurship during a systemic transformation [Rona-Tas, Sagi, 2005; Sauka, Welter, 2007; et al.];

- Identifying and analyzing the role of institutional traps that appear as a result of the import of institutions and best practices; analyzing the evolution of small and medium business development policies [Welter, Smallbone, 2011a].

New theoretical approaches emerging in the scope of institutional theory allow one to critically rethink the development of entrepreneurship in post-socialist countries. Employing a wide range of empirical data available to researchers, they allow one to make quantitative comparisons beyond the scope of official statistics. For example, our study [Chepurenko, 2015] suggests a cluster-based approach to measuring business activity as an extension of the "different transformations" concept (similar to the "different capitalism" models) [Hall, Soskice, 2001]). The diversity of entrepreneurial ecosystems is manifested through the disparity between the so-called entrepreneurial framework conditions (EFC) and the level of entrepreneurial activity in post-socialist countries. This concept does not refer to path dependence, i.e., the state of societies before the beginning of systemic transition alone, but finds classification criteria in the conditions and institutions that have emerged over the course of the systemic transformation process itself. According to the GEM explanatory model, entrepreneurial framework conditions reflecting the socioeconomic context [Welter, 2011] include a set of institutions that affect the quality of the business environment and are measured using 10 indicator groups. The GEM has no integrated EFC indicator, therefore as a substitute for a national-level EFC index, we used an indicator calculated as the difference between the share of nascent business owners and the share of individuals who have shut down a business over the past year among the adult population provided by the GEM APS data. The difference between the number of those persons entering and leaving entrepreneurial activity over the same period of time though it can be due in part to personal circumstances and motives - would still be representative enough to illustrate the entrepreneurs' perceptions of the framework conditions for their activities. As the GEM annual monitoring surveys show, this perception turned out to be decisive for the establishment and liquidation of new firms alike. Thus, the quality of the entrepreneurial framework conditions can be expressed using the following formula: 


\section{Table 4. Distribution of post-socialist economies depending on the quality of entrepreneurial} framework conditions and entrepreneurial potential (2011)

\begin{tabular}{|l|l|l|l|}
\hline & $\left(T E A_{\text {IDE }}-T E A_{\text {nec }}\right): T E A_{\text {mixed }}<0$ & $0<\left(T E A_{\text {IDE }}-T E A_{\text {nec }}\right): T E A_{\text {mixed }}<1$ & $\left(T E A_{\text {IDE }}-T E A_{\text {nec }}\right): T E A_{\text {mixed }}>1$ \\
\hline$\Delta$ of $T E A<0$ & Bosnia and Herzegovina & - & - \\
\hline $0<\Delta$ of $T E A<2$ & Croatia, Poland, Romania & Russia & Slovenia \\
\hline$\Delta$ of $T E A>2$ & Hungary & Latvia, Lithuania, Slovakia & Czech Republic \\
\hline \multicolumn{2}{|l}{ Source: calculated by the author on the basis of materials in [Bosma et al., 2012]. } \\
\hline
\end{tabular}

$$
\triangle o f T E A=\left(B B O-B U S_{\text {disc }}\right),
$$

where:

$B B O$ is the share of nascent entrepreneurs, and

$B U S_{d i s c}$ is the share of people who have discontinued their entrepreneurial activities over the course of the previous year.

The 'quality' of entrepreneurial activity does not solely reflect entrepreneurs' ability to contribute to employment and economic growth in a country. As it is shown [Schillo, Persault, 2016], entrepreneurial intentions not only reflect individuals' willingness to become entrepreneurs, but also certain components of the national business environment. Motivation, its character - driven by opportunity or necessity is one of the parameters governing individual entrepreneurial aspirations, while the structure of that motivation, or the ratio of improvement-driven entrepreneurship (IDE) and necessity-driven activity is an important indicator for the entrepreneurial potential of the population. Numerous empirical studies [Hessels et al., 2008; Shane et al., 2003] demonstrate that various motivations affect goal-setting and the entrepreneurial strategies of newly established and developing firms, i.e., their potential for growth, export, and innovation - differently. Moreover, the GEM methodology [Reynolds et al., 2005] focuses on differences in entrepreneurs' motivation in various countries, and especially on its effect on the socalled U-curve of the correlation between entrepreneurial activity and economic development in various groups of countries [Reynolds et al., 2005]. The difference between prevailing entrepreneurial motivation (IDE or necessity) divided by the share of those motivated by mixed considerations can be used as an indicator of the quality of entrepreneurial activity, i.e.:

where:

$$
\left(T E A_{I D E}-T E A_{n e c}\right): T E A_{\text {mixed }} \text {, }
$$

$T E A_{I D E}$ is the share of improvement-driven early-stage entrepreneurs,

$T E A_{n e c}$ is the share of necessity-driven early-stage entrepreneurs, and

$T E A_{\text {mixed }}$ is the share of early-stage entrepreneurs with mixed motivations correlated with their ambitions for growth and job creation.

$T E A_{\text {mixed }}$ is an important indicator because in certain economies, a large, occasionally even predominant, share of early-stage entrepreneurs are motivated both by necessity and opportunity, so taking into consideration only these two types does not completely cover the motivational structure of nascent businessmen in the relevant national samples.

The GEM data for 2011 (the year with the highest concentration of post-socialist countries in the GEM over the recent period of the project's implementation) allowed [Chepurenko, 2015] to obtain a quite precise picture of the framework conditions and entrepreneurial activity in several countries (Table 3).

Taking into account the entrepreneurial framework conditions and the quality of entrepreneurial potential (presented as two axes), a model for clustering post-social economies by entrepreneurship ecosystem type was built (Table 4).

\section{Table 5. Entrepreneurial ecosystems in post-socialist countries}

\begin{tabular}{|l|l|l|}
\hline \multicolumn{1}{|c|}{ Country } & Quality of entrepreneurial activity & Framework conditions \\
\hline Bosnia and Herzegovina & Low & Poor \\
\hline Poland, Romania, Croatia & Low & Average \\
\hline Hungary & Low & Best \\
\hline Russia & Average & Average \\
\hline Latvia, Lithuania, Slovakia & Average & Best \\
\hline Slovenia & Best & Average \\
\hline Czech Republic & Best & Best \\
\hline \multicolumn{2}{|l|}{ Source: composed by the author on the basis of data in [Bosma et al., 2012]. } \\
\hline
\end{tabular}


$\triangle o f T E A<0$ means that entrepreneurial framework conditions in the relevant country are very poor; $0<\triangle$ of $T E A<2$ means they are satisfactory; and $\triangle O f T E A>2$ implies relatively favorable conditions. The values of $\left(T E A_{I D E}-T E A_{\text {nec }}\right): T E A_{\text {mixed }}<0$ indicate the low quality of entrepreneurship. In countries falling within the range of $0<\left(T E A_{I D E}-T E A_{\text {nec }}\right): T E A_{\text {mixed }}<1$ entrepreneurial activity can be assessed as satisfactory, and those whose values reach the level of $\left(T E A_{I D E}-T E A_{\text {nec }}\right): T E A_{\text {mixed }}>1$ have the best conditions for the development of entrepreneurship. The relevant GEM data allows one to rank entrepreneurial ecosystems of post-socialist countries (Table 5).

Some countries, such as Russia or Hungary, look better than could be expected on the basis of expert assessments of their current economic and political situations; others (e.g., Poland) conversely do not live up to expectations. Nevertheless, the results illustrate our main point: 20 years after the beginning of systemic transformation in European socialist countries and the former Soviet Union, entrepreneurial ecosystems and related conditions are quite different. Among other things this means that specific approaches need to be employed both to analyze the reasons and to make policy recommendations to improve framework conditions for and provide support to entrepreneurship and SMEs in the aforementioned countries. Weak points of our evidence include the limited range of post-socialist economies covered by the GEM project: most of the CIS and Balkan countries do not take part in it at all, while some others only participate in certain rounds, which makes it difficult to obtain dynamic data arrays covering several years. Accordingly, only two groups out of seven include more than one country, which reduces the value of such a classification.

A comparatively novel mechanism for an international comparison of entrepreneurial development was proposed in the scope of the so-called knowledge spill-over theory of entrepreneurship (KSTE): the Global Entrepreneurship Development Index (GEDI). This integrated indicator is calculated on the basis of 31 variables divided into 14 groups, which in turn are subsumed into three sub-indices [Acs, Szerb, 2011]. The authors assume a set of individual and institutional characteristics exists in each country at a particular period of time, which together constitute a national entrepreneurship system (NES):

'... A National System of Entrepreneurship is the dynamic, institutionally embedded interaction between entrepreneurial attitudes, ability, and aspirations by individuals, which drives the allocation of resources through the creation and operation of new ventures' [Acs et al., 2014, p. 479].

The NES concept is systemic due to the fact that the cumulated impact of all the factors it comprises is larger than their sum. Unlike the microlevel (characteristics of, and resources available to, specific entrepreneurs) and mesolevel (networks, trust, etc.) approaches, the NES concept assumes that the development of entrepreneurship is affected by societal and institutional factors. However, this perspective reduces the problem to conditions for establishing and operating new companies, hence it follows that the definition of entrepreneurship reads solely as the process of establishing and managing of new ventures. A less restrictive concept of an entrepreneurial system was put forward by [Autio, Levie, 2015], which describes the relationship between all processes and stages of development through the institutional context, seems to be more appropriate.

Another limitation of the index built in the scope of the NES concept is the sources of data for calculating it. Along with surveys of the economically active adult population and entrepreneurs within the framework of the GEM project, certain variables are borrowed from databases maintained by organizations who use different measurement techniques (statistical, expert-based, etc.), which makes the whole GEDI index highly subjective. In addition, the aggregated sub-indices are not weighted when the overall index is calculated: their arithmetic mean is simply extracted [Acs, Szerb, 2011]. This approach does not take into account the various weights of the same factors when decisions to create a new company or carry on with the business are made in different types of economies. It contradicts, for instance, the NES concept authors' thesis that, high-tech start-ups can play a more important role in countries where large public companies dominate than in economies in which most of the firms are SMEs [Acs et al., 2013]. For the latter group of nations (which includes almost the whole of CEE), the low level of high-tech entrepreneurship seems to be less critical to the quality of business environment than the level of people's education and entrepreneurial skills. Therefore, the value of this indicator for very different economies should be adjusted using a reduced weight coefficient. Consequently, some distortions are embedded in the GEDI methodology by definition.

Nevertheless, a comparison of GEDI values [Szerb, Trumbull, 2015] confirms the economic, societal, and cultural heterogeneity of post-socialist countries, which manifests itself in the different entrepreneurial ecosystems. Most of them match the level of more advanced non-European economies (see Table 6), with widely varying index values (ranging from 57.8 in Estonia to 30.4 in the bottom-ranking Bosnia and Herzegovina) - which makes the inclusion of "post-socialist countries" in a group of their own pointless. The classification suggested by the World Economic Forum (WEF) [WEF, 2015] in a number of cases raises similar doubts. For example, on the basis of per capita GDP figures, Italy and Greece are included in the group of innovative economies in the middle of the ranking, while Brazil (included in the second group of efficiency-driven economies) finds itself among the countries with the least developed entrepreneurship. All in all, such biases make one doubt the relevance of the per capita GDP indicator for typologizing countries and economies in the first place. 


\section{Table 6. Post-socialist countries in the GEDI Ranking (2012)}

\begin{tabular}{|c|c|c|c|c|c|c|c|c|c|}
\hline Ranking & Country & $\begin{array}{l}\text { GDP } \\
\text { (USD) }\end{array}$ & GEDI & \begin{tabular}{|c}
$\begin{array}{c}\text { Development } \\
\text { level }\end{array}$ \\
\end{tabular} & Ranking & Country & $\begin{array}{l}\text { GDP } \\
\text { (USD) }\end{array}$ & GEDI & $\begin{array}{c}\text { Development } \\
\text { level }\end{array}$ \\
\hline 1 & US & 42486 & 79.4 & 3 & 43 & Italy & 27072 & 41.3 & 3 \\
\hline 2 & Denmark & 32582 & 77.1 & 3 & 44 & Barbados & 17564 & 40.7 & 2 \\
\hline 3 & Australia ${ }^{*}$ & 34396 & 74.3 & 3 & 45 & Montenegro ${ }^{* *}$ & 10469 & 40.7 & 2 \\
\hline 4 & Sweden & 35170 & 71.5 & 3 & 46 & South Africa & 9678 & 39.6 & 2 \\
\hline 5 & Taiwan & Н/д & 68.4 & 3 & 47 & Greece & 22301 & 39.5 & 3 \\
\hline 6 & France & 29819 & 68.2 & 3 & 48 & China & 7418 & 39.5 & 2 \\
\hline 7 & UK & 32863 & 67.8 & 3 & 49 & Tunis & 8258 & 39.2 & 2 \\
\hline 8 & Switzerland & 39412 & 67.3 & 3 & 50 & $\begin{array}{l}\text { Dominican } \\
\text { Republic }^{* \star \star}\end{array}$ & 8651 & 39.0 & 2 \\
\hline 9 & Netherlands & 37112 & 66.1 & 3 & 51 & Argentina & 15501 & 38.9 & 2 \\
\hline 10 & Iceland $^{* *}$ & 33516 & 66.0 & 3 & 52 & Costa Rica & 10735 & 38.0 & 2 \\
\hline 11 & Finland & 32027 & 65.7 & 3 & 53 & Macedonia & 9451 & 38.0 & 2 \\
\hline 12 & Singapore & 53591 & 65.1 & 3 & 54 & Mexico & 12814 & 37.9 & 2 \\
\hline 13 & Norway & 46982 & 65.1 & 3 & 55 & Jordan $^{* \star *}$ & 5268 & 36.2 & 2 \\
\hline 14 & Belgium & 33127 & 64.1 & 3 & 56 & Serbia & 9830 & 35.6 & 2 \\
\hline 15 & Germany & 34603 & 63.1 & 3 & 57 & Botswana & 13021 & 35.4 & 1 \\
\hline 16 & Chile & 15251 & 62.5 & 2 & 58 & Namibia & 5986 & 34.5 & 2 \\
\hline 17 & Ireland & 36145 & 61.6 & 3 & 59 & Panama & 13766 & 34.4 & 2 \\
\hline 18 & Austria & 36139 & 61.5 & 3 & 60 & Thailand & 7635 & 34.2 & 2 \\
\hline 19 & Israel & 26720 & 58.0 & 3 & 61 & Russia & 14821 & 33.6 & 2 \\
\hline 20 & Estonia & 18129 & 57.8 & 2 & 62 & Nigeria & 2237 & 33.3 & 1 \\
\hline 21 & Slovenia & 24967 & 52.8 & 3 & 63 & $\begin{array}{l}\text { Trinidad and } \\
\text { Tobago }\end{array}$ & 22142 & 32.6 & 2 \\
\hline 22 & South Korea & 27541 & 52.2 & 3 & 64 & Morocco $^{* * *}$ & 4373 & 32.4 & 2 \\
\hline 23 & Saudi Arabia** & 21430 & 51.1 & 1 & 65 & Jamaica* $^{*}$ & Н/д & 32.3 & 2 \\
\hline 24 & Poland & 18087 & 50.5 & 2 & 66 & Salvador & 6032 & 31.9 & 2 \\
\hline 25 & Colombia & 8860 & 50.0 & 2 & 67 & Bolivia** & 4503 & 31.6 & 1 \\
\hline 26 & Lithuania & 16877 & 49.8 & 2 & 68 & Algeria & 7643 & 31.3 & 1 \\
\hline 27 & Turkey & 13468 & \begin{tabular}{|l|l|}
49.7 &
\end{tabular} & 2 & 69 & Egypt & 5547 & 30.8 & 1 \\
\hline 28 & UAE $^{*}$ & 42293 & 48.7 & 3 & 70 & $\begin{array}{l}\text { Bosnia and } \\
\text { Herzegovina }\end{array}$ & 7607 & 30.4 & 2 \\
\hline 29 & Latvia & 13773 & 48.7 & 2 & 71 & Ecuador & 7655 & 29.7 & 2 \\
\hline 30 & Spain & 26917 & 47.8 & 3 & 72 & Brazil & 10279 & 29.6 & 2 \\
\hline 31 & Japan & 30660 & 47.7 & 3 & 73 & Zambia & 1431 & 28.9 & 1 \\
\hline 32 & Hong Kong ${ }^{\star *}$ & 44640 & 47.0 & 3 & 74 & Angola & 5227 & 28.0 & 1 \\
\hline 33 & Czech Republic ${ }^{*}$ & 24011 & 46.9 & 3 & 75 & Venezuela* ${ }^{*}$ & 11258 & 28.0 & 1 \\
\hline 34 & Slovakia & 20757 & 46.8 & 3 & 76 & Iran & 10462 & 27.3 & 1 \\
\hline 35 & Portugal & 21304 & 46.4 & 3 & 77 & Ghana & 1652 & 26.7 & 1 \\
\hline 36 & Romania & 10905 & 45.7 & 2 & 78 & Pakistan & 2424 & 24.2 & 1 \\
\hline 37 & Uruguay & 13315 & 45.1 & 2 & 79 & Guatemala $^{*}$ & 4351 & 22.9 & 1 \\
\hline 38 & Hungary & 17295 & 43.3 & 2 & 80 & Malawi & 789 & 21.3 & 1 \\
\hline 39 & Malaysia & 14174 & 43.3 & 2 & 81 & Ethiopia & 979 & 21.1 & 1 \\
\hline 40 & Lebanon $^{* * *}$ & 12900 & 42.6 & 2 & 82 & Uganda & 1188 & 20.1 & 1 \\
\hline 41 & Peru & 9037 & 42.4 & 2 & 83 & Bangladesh $^{*}$ & 1569 & 18.6 & 1 \\
\hline 42 & Croatia & 15954 & 41.5 & 2 & & & & & \\
\hline \multicolumn{10}{|c|}{$\begin{array}{l}\text { Notes: GDP means per capita GDP (PPP) for } 2011 \text { in } 2005 \text { prices, according to World Bank data; development level }=\text { the country’s development level } \\
\text { calculated using the WEF methodology: } 1 \text { - factor-driven economies, } 2 \text { - efficiency-driven economies, and } 3 \text { - innovation-driven economies. } \\
{ }^{*} \text { Data for } 2011 \text {; }{ }^{* *} \text { Data for 2010; } * * * \text { Data for } 2009 \text {. } \\
\text { Source: [Szerb, Trumbull, 2015]. }\end{array}$} \\
\hline
\end{tabular}


Table 7. GEDI deviations from the main trend for each of the four groups of countries

\begin{tabular}{|l|r|r|l|r|r|}
\hline \multicolumn{1}{|c|}{ Country } & GEDI & $\begin{array}{r}\text { GEDI } \\
\text { deviation } \\
\text { from trend }\end{array}$ & \multicolumn{1}{|c|}{ Country } & $\begin{array}{r}\text { GEDI } \\
\text { GEDI } \\
\text { from trend }\end{array}$ \\
\hline Czech Republic & 46.9 & -5.0 & Bosnia and Herzegovina & 30.4 & -3.4 \\
\hline Estonia & 57.8 & 12.4 & Croatia & 41.5 & -1.5 \\
\hline Hungary & 43.3 & -1.2 & Macedonia & 38.0 & 2.2 \\
\hline Latvia & 48.7 & 8.2 & Montenegro & 40.7 & 3.8 \\
\hline Lithuania & 49.8 & 5.8 & Serbia & 35.6 & -0.6 \\
\hline Poland & 50.5 & 5.2 & Slovenia & 52.8 & -0.1 \\
\hline Romania & 45.7 & 8.3 & Average for former European market socialist economies & 39.8 & \\
\hline Russia & 33.6 & -8.1 & Average for transitioning European economies & 44.1 & 0.1 \\
\hline Slovakia & 46.8 & -1.6 & Average for non-transitioning European economies & 61.2 & 1.6 \\
\hline $\begin{array}{l}\text { Average for former European } \\
\text { planned socialist economies }\end{array}$ & 47.0 & 2.7 & Average for efficiency-driven European economies & 39.0 & 1.5 \\
\hline Source: [Szerb, Trumbull, 2015]. & & & 2.1 \\
\hline
\end{tabular}

All countries were further clustered and divided into four groups (two study groups and two control ones) [Szerb, Trumbull, 2015]: the former planned socialist economies and former market socialist economies on the one hand, and the non-transitional efficiency-driven countries, on the other (since the vast majority of post-socialist countries are efficiency-driven in terms of their economic development level). It resulted, firstly, in the discovery of a statistically significant gap between the average level of entrepreneurial development in post-socialist and other European countries. While in the first group the GEDI index was close to 44, countries that did not go through a systemic transformation phase usually had a value at around 61, i.e., a $28 \%$ gap in favor of non-transitional economies (Table 7). Secondly, in terms of the development of entrepreneurship, post-social countries turned out to be closer to the group of efficiency-driven economies. According to [Szerb, Trumbull, 2015], this means that the level of economic development provides a satisfactory explanation for the disparities in entrepreneurial development [Szerb, Trumbull, 2015, p. 9-10].

However, the results obtained by grouping specific indicators (Table 8) refute the previous conclusion. Not only do post-socialist countries show weaker performance than other European nations in terms of expected and perceived cultural support of entrepreneurship, there is also significant heterogeneity among post-socialist countries. The differences are apparent both in individual (the first six groups of indicators) and institutional values, and were noted even between countries with quite similar per capita GDP figures. For example, Slovakia nearly exceeds Hungary by two-fold regarding the individual "Networking" indicator and the institutional "Venture capital" indicators; Estonia and Poland show a significant (1.5-2 times) gap in six of the 14 indicator groups; finally, two former Yugoslav republics, Macedonia and Montenegro, have quite different values in the two groups of individual indicators and the two groups of institutional ones.

An analysis of the dynamics of post-socialist economies' indicator values also produced a contradictory picture (Table 9). Data presented in [Szerb, Trumbull, 2015] indicates that the gap between these and other European countries' (i.e., those which have never been socialist) GEDI values is gradually narrowing. At the same time, during the period under consideration Slovenia's integral indicator value noticeably dropped (the WEF includes this nation in the group of innovation-driven economies); relevant figures for Latvia, the Czech Republic, and Macedonia have dropped insignificantly - by $2 \%$, just as they have in Russia. Only Hungary and Romania demonstrated statistically significant growth, while in Bosnia and Herzegovina and Croatia the growth was within the margin of error. However, it would be hard to call Hungary a liberal market economy. The overall picture displays rather stagnant or even negative processes in the "old" capitalist countries after the 2007 economic recession and the subsequent structural reforms in European countries. Their GEDI dynamics compared with the slow, positive dynamics of post-socialist economies casts the latter in a favorable light.

In other words, a comparison of post-socialist economies with one other is very difficult because it reveals quite different, occasionally even contradictory, dynamics of entrepreneurial development, while comparing them with other European countries might be deceptive. On the one hand, this might have to do with the base effect and recovery growth; on the other, with the weak growth of private businesses during the transition to a new socioeconomic and societal order by established market economies.

The value of the Entrepreneurial Aspirations Index, which is comprised of several indicators of the adult economically active population's willingness to establish a new venture during the period under consideration, has dropped or remained at least unchanged in six countries, while it grew only in three: 
Table 8. Distribution of European post-socialist countries by 14 groups of entrepreneurial development indicators, compared with other nations

\begin{tabular}{|c|c|c|c|c|c|c|c|c|c|c|c|c|c|c|c|c|c|}
\hline Country & 1 & 2 & 3 & 4 & 5 & 6 & 7 & 8 & 9 & 10 & 11 & 12 & 13 & 14 & $\begin{array}{c}\text { Average for } \\
\text { institutional } \\
\text { factors }\end{array}$ & $\begin{array}{c}\text { Average } \\
\text { for specific } \\
\text { factors }\end{array}$ & GEDI \\
\hline Czech Republic & 0.34 & 0.53 & 0.21 & 0.49 & 0.34 & 0.45 & 0.56 & 0.24 & 0.52 & 0.68 & 0.79 & 0.89 & 1.00 & 0.53 & 0.68 & 0.64 & 46.9 \\
\hline Estonia & 0.38 & 0.59 & 0.48 & 0.78 & 0.54 & 0.60 & 0.75 & 0.51 & 0.65 & 0.63 & 0.62 & 0.73 & 0.90 & 0.38 & 0.70 & 0.68 & 57.8 \\
\hline Hungary & 0.18 & 0.52 & 0.28 & 0.46 & 0.49 & 0.50 & 0.66 & 0.41 & 0.46 & 0.46 & 0.44 & 0.72 & 0.81 & 0.36 & 0.64 & 0.58 & 43.3 \\
\hline Latvia & 0.26 & 0.58 & 0.30 & 0.60 & 0.42 & 0.52 & 0.53 & 0.57 & 0.54 & 0.55 & 0.37 & 1.00 & 0.78 & 0.42 & 0.60 & 0.66 & 48.7 \\
\hline \begin{tabular}{|l|} 
Lithuania \\
\end{tabular} & 0.27 & 0.59 & 0.37 & \begin{tabular}{|l|}
0.55 \\
\end{tabular} & 0.47 & 0.53 & 0.53 & 0.83 & 0.43 & 0.40 & 0.43 & 0.94 & 0.75 & 0.46 & 0.65 & 0.65 & 49.8 \\
\hline \begin{tabular}{|l|} 
Poland \\
\end{tabular} & 0.38 & 0.82 & 0.38 & \begin{tabular}{|l|}
0.71 \\
\end{tabular} & 0.55 & 0.32 & 0.42 & 0.33 & 0.54 & 0.82 & 0.41 & 0.67 & 0.86 & 0.52 & 0.69 & 0.62 & 50.5 \\
\hline \begin{tabular}{|l|} 
Romania \\
\end{tabular} & 0.38 & 0.50 & 0.29 & \begin{tabular}{|l|}
0.37 \\
\end{tabular} & 0.45 & 0.45 & 0.43 & 0.43 & 0.50 & 0.44 & 0.42 & 0.88 & 0.81 & 0.43 & 0.54 & 0.68 & 45.7 \\
\hline Russia & 0.44 & 0.46 & 0.29 & 0.49 & 0.26 & 0.44 & 0.31 & 0.83 & 0.31 & 0.27 & 0.36 & 0.49 & 0.08 & 0.33 & 0.60 & 0.49 & 33.6 \\
\hline \begin{tabular}{|l|} 
Slovakia \\
\end{tabular} & 0.21 & 0.60 & 0.46 & \begin{tabular}{|l|}
0.91 \\
\end{tabular} & 0.41 & 0.46 & 0.52 & 0.31 & 0.40 & 0.50 & 0.43 & 0.59 & 0.87 & 0.81 & 0.64 & 0.66 & 46.8 \\
\hline \begin{tabular}{|l} 
Bosnia and \\
Herzegovina
\end{tabular} & 0.15 & 0.40 & 0.11 & 0.49 & 0.47 & 0.20 & 0.43 & 0.24 & 0.41 & 0.23 & 0.26 & 0.44 & 0.47 & 0.41 & 0.48 & 0.54 & 30.4 \\
\hline \begin{tabular}{|l|} 
Croatia \\
\end{tabular} & 0.18 & 0.54 & 0.28 & \begin{tabular}{|l|}
0.48 \\
\end{tabular} & 0.36 & 0.39 & 0.58 & 0.31 & 0.49 & 0.35 & 0.48 & 0.64 & 0.83 & 0.54 & 0.57 & 0.64 & 41.5 \\
\hline \begin{tabular}{|l|} 
Macedonia \\
\end{tabular} & 0.23 & 0.45 & 0.19 & \begin{tabular}{|l|}
0.49 \\
\end{tabular} & 0.42 & 0.36 & 0.39 & 0.37 & 0.46 & 0.36 & 0.36 & 0.46 & 0.70 & 0.43 & 0.50 & 0.65 & 38.0 \\
\hline Montenegro & 0.22 & 0.72 & 0.20 & \begin{tabular}{|l|}
0.66 \\
\end{tabular} & 0.44 & 0.43 & 0.29 & 0.33 & 0.32 & 0.35 & 0.66 & 0.46 & 0.86 & 0.43 & 0.52 & 0.67 & 40.7 \\
\hline \begin{tabular}{|l|} 
Serbia \\
\end{tabular} & 0.37 & 0.73 & 0.25 & \begin{tabular}{|l|}
0.61 \\
\end{tabular} & 0.37 & 0.33 & 0.29 & 0.23 & 0.35 & 0.29 & 0.57 & 0.35 & 0.24 & 0.34 & 0.48 & 0.59 & 35.6 \\
\hline \begin{tabular}{|l|} 
Slovenia \\
\end{tabular} & 0.16 & 1.00 & 0.51 & \begin{tabular}{|l|}
0.75 \\
\end{tabular} & 0.55 & 0.66 & 1.00 & 0.60 & 0.53 & 0.61 & 0.71 & 0.63 & 0.77 & 0.44 & 0.70 & 0.70 & 52.8 \\
\hline $\begin{array}{l}\text { Average for former } \\
\text { European planned } \\
\text { socialist economies }\end{array}$ & 0.32 & 0.58 & 0.34 & \begin{tabular}{|l|}
0.60 \\
\end{tabular} & 0.44 & 0.47 & 0.52 & 0.50 & 0.48 & 0.53 & 0.47 & \begin{tabular}{|l|}
0.77 \\
\end{tabular} & 0.76 & 0.47 & 0.64 & 0.63 & 47.0 \\
\hline \begin{tabular}{|l|} 
Average for former \\
European market \\
socialist economies
\end{tabular} & 0.22 & 0.64 & 0.26 & \begin{tabular}{|l|l}
0.58 \\
\end{tabular} & 0.44 & 0.40 & 0.50 & 0.35 & 0.43 & 0.37 & 0.51 & 0.50 & 0.65 & 0.43 & 0.54 & 0.63 & 39.8 \\
\hline \begin{tabular}{|l} 
Average for \\
European post- \\
socialist countries
\end{tabular} & 0.28 & 0.60 & 0.31 & \begin{tabular}{|l|}
0.59 \\
\end{tabular} & 0.44 & 0.44 & 0.51 & 0.44 & 0.46 & 0.46 & 0.49 & 0.66 & 0.72 & 0.46 & 0.60 & 0.63 & 44.1 \\
\hline \begin{tabular}{|l} 
Average for other \\
European countries
\end{tabular} & 0.59 & 0.62 & 0.51 & 0.72 & 0.69 & 0.69 & 0.80 & 0.68 & 0.69 & 0.71 & 0.71 & 0.51 & 0.69 & 0.66 & 0.82 & 0.65 & 61.2 \\
\hline \begin{tabular}{|l|} 
Average for \\
efficiency-driven \\
European economies
\end{tabular} & 0.59 & 0.50 & 0.46 & 0.46 & 0.47 & 0.46 & 0.33 & 0.35 & 0.45 & 0.49 & 0.35 & 0.42 & 0.35 & 0.37 & 0.58 & 0.59 & 39.0 \\
\hline
\end{tabular}

Note: 1. Perceived opportunities (ATT); 2. Initial skills (ATT); 3. Perceived risk (ATT); 4. Networking (ATT); 5. Cultural support (ATT); 6. Early-stage opportunity-driven entrepreneurship (ABT); 7. Technology sector (ABT); 8. Quality of human resources (ABT); 9. Competition (ABT); 10. Product innovations (ASP); 11. Process innovations (ASP); 12. High growth rate (ASP); 13. Internationalization (ASP); 14. Venture capital (ASP).

GEDI - GEDI ranking; ATT — attitudes; ABT — abilities; ASP — aspirations.

Source: [Szerb, Trumbull, 2015].

Hungary, Romania, and Macedonia. In our opinion, it is precisely the level of entrepreneurial aspirations that most accurately reflects people's perceptions of their own abilities and the opportunities for successful entrepreneurial activity. In the GEDI methodology, this indicator is measured on the basis of the overall TEA without talking into account the share of necessity-driven entrepreneurship. If the latter would be taken into account, the conditions of entrepreneurial activity would be estimated less positively even in countries where entrepreneurial aspirations have improved.

Thus, significant differences between post-socialist countries are apparent both in the level and the rate of the development of entrepreneurship. Neither similar economic development levels nor a "common past" can explain the full extent of their disparity. Hence, new theoretical approaches to classifying the economies in question and their entrepreneurial ecosystems are needed.

\section{Paradigm concepts for classifying post-socialist countries' entrepreneurial ecosystems}

The institutional theory ${ }^{3}$ has sufficient conceptual resources for a detailed, substantiated classification of entrepreneurial ecosystems in post-social countries. Essentially, we mean that the theory differentiates between inclusive and extractive institutions and thus explains why some countries become successful and others do not [Acemoğlu, Robinson, 2012], as well as the concept of free versus limited access to

\footnotetext{
To provide a theoretical substantiation for the suggested approach, Zoltan Acs and co-authors [Acs et al., 2016, p. 530] employ three concepts: "national innovation system" [Nelson, 1993], "national comparative competitive advantage" [Porter, 1990], and "competition and entrepreneurship" [Kirzner, 1973] without even mentioning such concepts as "varieties of capitalism" [Hall, Soskice, 2001], "inclusive and extractive institutions" [Acemoğlu, Robinson, 2012], or the "access orders" theory [North et al., 2009].
} 
Table 9. Dynamics of the GEDI and three sub-indices by country, in 2006-2009 and 2010-2012

\begin{tabular}{|c|c|c|c|c|c|c|c|c|c|c|c|c|}
\hline \multirow{2}{*}{ Country } & $\begin{array}{c}2006- \\
2009\end{array}$ & $\begin{array}{c}2010- \\
2012 \\
\end{array}$ & \begin{tabular}{c|}
$2006-$ \\
2009
\end{tabular} & $\begin{array}{c}2010- \\
2012 \\
\end{array}$ & $\begin{array}{c}2006- \\
2009\end{array}$ & $\begin{array}{c}2010- \\
2012\end{array}$ & $\begin{array}{c}2006- \\
2009\end{array}$ & $\begin{array}{c}2010- \\
2012\end{array}$ & \multicolumn{4}{|c|}{$\begin{array}{l}\text { Growth from 2006-2009 } \\
\text { to } 2010-2012\end{array}$} \\
\hline & \multicolumn{2}{|c|}{ GEDI } & \multicolumn{2}{|c|}{ ATT } & \multicolumn{2}{|c|}{$\mathrm{ABT}$} & \multicolumn{2}{|c|}{ ASP } & GEDI & ATT & ABT & ASP \\
\hline Czech Republic & 51.0 & 50.2 & 42.4 & 42.8 & 43.1 & 42.8 & 67.4 & 64.9 & -0.8 & 0.4 & -0.3 & -2.5 \\
\hline Hungary & 37.4 & 46.0 & 41.1 & 42.1 & 40.6 & 48.7 & 30.4 & 47.1 & 8.6 & 1.0 & 8.1 & 16.7 \\
\hline Latvia & 49.6 & 47.5 & 45.7 & 44.3 & 52.6 & 47.6 & 50.6 & 50.6 & -2.2 & -1.4 & -5.0 & -0.1 \\
\hline Romania & 40.3 & 42.3 & 33.4 & 36.9 & 42.2 & 41.5 & 45.2 & 48.3 & 2.0 & 3.5 & -0.7 & 3.1 \\
\hline Russia & 34.6 & 32.6 & 27.1 & 31.2 & 43.3 & 38.4 & 33.4 & 28.1 & -2.0 & 4.1 & -4.9 & -5.3 \\
\hline Bosnia and Herzegovina & 30.3 & 30.5 & 31.5 & 31.2 & 25.0 & 28.5 & 34.2 & 32.0 & 0.3 & -0.3 & 3.4 & -2.2 \\
\hline Croatia & 43.3 & 43.9 & 44.8 & 38.5 & 34.9 & 44.1 & 50.3 & 49.1 & 0.6 & -6.3 & 9.2 & -1.2 \\
\hline Macedonia & 38.9 & 38.7 & 39.7 & 36.0 & 36.1 & 36.7 & 40.8 & 43.5 & -0.1 & -3.7 & 0.6 & 2.6 \\
\hline Slovenia & 58.0 & 53.9 & 58.6 & 52.5 & 58.4 & 55.6 & 57.1 & 53.6 & -4.1 & -6.2 & -2.8 & -3.4 \\
\hline $\begin{array}{l}\text { Average for former } \\
\text { European planned } \\
\text { socialist economies }\end{array}$ & 42.6 & 43.7 & 37.9 & 39.5 & 44.4 & 43.8 & 45.4 & 47.8 & 1.1 & 1.5 & -0.6 & 2.4 \\
\hline $\begin{array}{l}\text { Average for former } \\
\text { European market } \\
\text { socialist economies }\end{array}$ & 42.6 & 42.2 & 42.5 & 39.5 & 39.8 & 41.8 & 45.6 & 45.2 & -0.5 & -3.0 & 2.0 & -0.4 \\
\hline $\begin{array}{l}\text { Average for European } \\
\text { post-socialist countries }\end{array}$ & 42.6 & 42.8 & 40.5 & 39.5 & 41.8 & 42.7 & 45.5 & 46.4 & 0.2 & -1.0 & 0.9 & 0.9 \\
\hline $\begin{array}{l}\text { Average for other } \\
\text { European countries }\end{array}$ & 63.0 & 61.2 & 62.5 & 60.6 & 64.8 & 63.2 & 61.6 & 59.8 & -1.8 & -1.9 & -1.6 & -1.8 \\
\hline $\begin{array}{l}\text { Average for efficiency- } \\
\text { driven European } \\
\text { economies }\end{array}$ & 39.5 & 40.9 & 41.6 & 45.5 & 38.5 & 38.7 & 38.2 & 38.7 & 1.4 & 3.8 & 0.2 & 0.4 \\
\hline
\end{tabular}

the market [North et al., 2009]. These theories allow one to explain why in different socioeconomic contexts, even given comparable economic development levels, different entrepreneurial ecosystems may emerge - based on productive, non-productive, and destructive entrepreneurship as well as their various combinations [Baumol, 1990].

According to Daron Acemoğlu and James Robinson, in countries with market economies and established democracies, the "organic" inclusive institutions play a leading role, i.e. those that support the reproduction of the socioeconomic system [Acemoğlu, Robinson, 2012]. On the contrary, if a market economy is weak and civil society is poorly developed (as is the case in some of the transitioning post-socialist countries, especially those outside the legal and institutional orbit of the EU), so-called "extractive" political and/ or economic institutions could emerge. Their specific feature is a concentration of political authority in the hands of a weak government incapable of providing basic social security to its citizens [Acemoğlu, Robinson, 2012]. At this point, Acemoğlu and Robinson's concept merges with the limited access concept proposed by North et al. [North et al., 2009]. Extractive economic institutions, which do not guarantee property rights or limit the power of monopolies, lead to the emergence of limited market access for actors not integrated into the government bureaucracy.

Various combinations of inclusive and extractive institutions lead to different configurations of entrepreneurial ecosystems (see Table 10). In post-socialist countries, these systems are either based on inclusive institutions (e.g., some of the CEE countries that are new members of the EU), or are hybrid ones, i.e., those combining formally inclusive political institutions with de facto extractive economic ones (such as CIS countries and some of the former Yugoslav republics).

Societal and institutional differences between the two extremes on the "open access - limited access" scale determine the framework conditions for the development of national entrepreneurial ecosystems. The less productive systems are also affected by economic factors that accompany systemic transformation and create a kind of vicious circle where the primitive structure of the economy leaves no opportunity for the emergence of innovative entrepreneurship. Such negative factors include the following:

- Low labor productivity inherited from the previous socioeconomic system: after twenty-five years since the beginning of reforms in most of these countries, this indicator's value ranges between $30 \%$ and $70 \%$ of advanced European economies' level. As a consequence, domestic products turn out to be more expensive than imported ones, so trade and services (such as catering, construction, repairs, etc.) become a natural niche for private entrepreneurship;

- Low effective demand from the population, especially at the initial stage of systemic transformation (the first half of the 1990s) prompts entrepreneurs to go into the informal sector of the economy to increase their revenues, with the government and "predatory businesses" pushing them further in the same direction [Feige, 1997; Williams, 2008; Scase, 2000; et al]. 
Table 10. Prevailing entrepreneurial forms amid the dominance of various types of economic and political institutions

\begin{tabular}{|c|c|c|c|}
\hline \multirow{2}{*}{\multicolumn{2}{|c|}{ Institutions }} & \multicolumn{2}{|r|}{ Political } \\
\hline & & Extractive & Inclusive \\
\hline \multirow[t]{2}{*}{ Economic } & Extractive & $\begin{array}{l}\text { Destructive entrepreneurship } \\
\text { prevails (some African and } \\
\text { Asian countries and regions } \\
\text { controlled by terrorist groups) }\end{array}$ & $\begin{array}{l}\text { Productive entrepreneurship serves the political } \\
\text { interests of the government and non-productive } \\
\text { entrepreneurs affiliated with it (some of the post- } \\
\text { socialist countries with de jure property rights de jure } \\
\text { in place, but with a de facto monopolized economy) }\end{array}$ \\
\hline & Inclusive & $\begin{array}{l}\text { Productive entrepreneurship } \\
\text { serves political interests of the } \\
\text { government (Greece, Chile } \\
\text { during the junta rule, etc.) }\end{array}$ & $\begin{array}{l}\text { Productive entrepreneurship defines the ecosystem } \\
\text { (the older and some of the new EU member states) }\end{array}$ \\
\hline
\end{tabular}

\section{Conclusions}

Our analysis confirms the previously suggested hypothesis that entrepreneurship ecosystems in postsocialist countries remain very heterogeneous due to a wide range of factors, among which a common past is an important but by no means only determinant. The level of these countries' economic development measured using the WEF criteria does not fully explain the disparities in the quality of their entrepreneurial environments and activities. Economies with similar GDP per capita development levels show different levels of entrepreneurial activities and vice versa. Over the course of systemic transformation, the post-socialist economies have demonstrated not only different rates, but different directions ("different systemic transformations"). As a result, some created conditions for the emergence of a favorable business climate based on predominantly productive entrepreneurship, while others put in place limited access orders with predominantly non-productive entrepreneurship.

The existing approaches to measuring the quality of entrepreneurial activities using quantitative indicators support the above conclusion, but also have obvious limitations. The NES concept and the related GEDI index [Acs et al., 2013, 2014, 2016] do allow one, under certain circumstances, to rank countries, but do not provide criteria for classifying them. These criteria have to be borrowed from other theories. An attempt to link the different access orders with the specific context and quality of entrepreneurial activities [Chepurenko, 2015] seems to be more promising in terms of classifying post-socialist countries, but it suffers from a lack of empirical data. Accordingly, the number of clusters in effect matches the number of clustering subjects.

Combining approaches to classifying transitional (hybrid, unstable) socioeconomic systems on the basis of the new concepts offered by institutional theory and the empirical analysis of framework conditions for development of entrepreneurship would help one more fully understand the specific features of entrepreneurial development in post-socialist countries. The variety of entrepreneurial paths, frameworks, ecosystems, and measures implemented to support small and medium private businesses should take into account the relevant individual characteristics of each specific post-socialist country, while any general recommendations tend to be less than effective.

The paper was written using materials obtained over the course of the project "Effects of specific regional budget and taxation policies on entrepreneurial potential" implemented within the scope of the HSE Basic Research Programme in 2016.

\section{References}

Acemoğlu D., Robinson J. (2012) Why Nations Fail: The Origins of Power, Prosperity, and Poverty, Danvers, MA: Crown Publishers.

Acs Z., Szerb L. (2011) The Global Entrepreneurship and Development Index 2011, Cheltenham: Edward Elgar Publishing.

Acs Z.J., Audretsch D.B., Lehmann E.E. (2013) The Knowledge Spillover Theory of Entrepreneurship. Small Business Economics, vol. 41, no 4, pp. 757-774. DOI: 10.1007/s11187-013-9505-9.

Acs Z.J., Audretsch D.B., Lehmann E.E., Licht G. (2016) National Systems of Entrepreneurship. Small Business Economics, vol.16, no 4, pp. 527-535. DOI: 10.1007/s11187-016-9705-1.

Acs Z.J., Autio E., Szerb L. (2014) National systems of entrepreneurship: Measurement issues and policy implications. Research Policy, vol. 43, no 3, pp. 476-494. DOI:10.1016/j.respol.2013.08.016.

Aidis R. (2005a) Entrepreneurship in transition countries: A review (UCL SSEES Working Papers 61), London: University College London.

Aidis R. (2005b) Institutional barriers to small- and medium-sized enterprise operations in transition countries. Small Business Economics, vol. 25, no 4, pp. 305-318. 
Aidis R., Estrin S., Mickiewicz T. (2010) Institutions, finance and the level of development: The impact on entrepreneurship in transition. Review of Economics and Institutions, vol. 1, no 1, Article 3. DOI: 10.5202/ rei.vli1.3. Available at: http://www.rei.unipg.it/rei/article/view/3, accessed 12.06.2017.

Amoros J., Bosma N. (2013) Global Entrepreneurship Monitor 2013 Global Report: Fifteen Years of Assessing Entrepreneurship Across the Globe, London: Global Entrepreneurship Research Association.

Autio E., Levie J. (2015) Management of Entrepreneurial Ecosystems, London: Imperial College Business School (mimeo).

Batjargal B. (2006) The dynamics of entrepreneurs' networks in a transitioning economy: The case of Russia. Entrepreneurship \& Regional Development, vol. 18, no 4, pp. 305-320.

Baumol W. (1990) Entrepreneurship: Productive, unproductive, and destructive. Journal of Political Economy, vol. 98, no 5, pp. 893-921.

Black B.S., Kraakman R., Tarassova A. (2000) Russian privatization and corporate governance: What went wrong? Stanford Law Review, vol. 52, no 6, pp. 1731-1808.

Blanchard O. (1998) The economics of post-communist transition, Oxford: Clarendon Press.

Bosma N., Wennekers S., Amoros J. (2012) Global Entrepreneurship Monitor 2011 Extended Global Report: Entrepreneurs and Entrepreneurial Employees Across the Globe, London: Global Entrepreneurship Research Association.

Boycko M., Shleifer A., Vishny R.W. (1997) Privatizing Russia, vol. 1, Cambridge, MA: MIT Press.

Chepurenko A. (2015) Entrepreneurial activity under 'transition'. Context, Process and Gender in Entrepreneurship (eds. R. Blackburn, U. Hytti, F. Welter), Cheltenham: Edward Elgar, pp. 6-22.

Chepurenko A.Y., Gabelko M., Obraztsova O. (2012) Early-stage entrepreneurial activity: An explanatory model for cross-country comparisons (HSE Working Paper WP1/2011/04), Moscow: HSE Publishing.

Chepurenko A. (2008) The 'Oligarhks' in Russian mass consciousness. Politics and the Ruling Group in Putin's Russia (ed. S. White), Basingstoke: Palgrave Macmillan, pp. 120-137.

Chilosi A. (2001) Entrepreneurship and transition. MOST: Economic Policy in Transitional Economies, vol. 11, no 4, pp. 327-357.

Cieslik J.A., van Stel A. (2012) Trends in entrepreneurial activity in Central and East European transition economies (Scales Research Reports H201202), Zoetermeer: EIM Business and Policy Research.

Commander S., Tolstopiatenko A. (1997) A model of the informal economy in transition economies (William Davidson Institute Working Paper no 22), Ann Arbor, MI: University of Michigan.

Dallago B. (1997) The economic system, transition and opportunities for entrepreneurship. Entrepreneurship and SMEs in Transition Economies, The Visegrad Conference, Paris: OECD, pp. 103-124.

Earle J., Sakova Z. (2000) Business start-ups or disguised unemployment? Evidence on the character of self employment from transition economies. Labour Economics, vol. 7, no 5, pp. 575-601.

Estrin S., Meyer K., Bytchova M. (2006) Entrepreneurship in transition economies. The Oxford Handbook of Entrepreneurship (eds. M. Casson, A. Basu, B. Yeung, N. Wadesdon), Oxford: Oxford University Press.

Estrin S., Mickiewicz T. (2010) Entrepreneurship in transition economies: The role of institutions and generational change. The dynamics of entrepreneurship: Evidence from the global entrepreneurship monitor data (ed. M. Minniti), Oxford: Oxford University Press, pp. 181-208.

Feige E. (1997) Underground activity and institutional change: Productive, protective, and predatory behaviour in transition economies. Transforming Post-Communist Political Economies (eds. J. Nelson, C. Tilly, L. Walkerm), Washington, D.C.: National Research Council, pp. 21-34.

Gros D., Steinherr A. (2004) Economic transition in Central and Eastern Europe: Planting the seeds, Cambridge: Cambridge University Press.

Hall P.A., Soskice D. (2001) Varieties of capitalism: The institutional foundations of comparative advantage, Oxford: Oxford University Press.

Hashi I., Krasniqi B. (2011) Entrepreneurship and SME Growth: Evidence from advanced and laggard transition economies, International Journal of Entrepreneurial Behaviour \& Research, vol. 17, no 5, pp. 456-487.

Hessels J., van Gelderen M., Thurik R. (2008) Entrepreneurial aspirations, motivations, and their drivers. Small Business Economics, vol. 31, no 3, pp. 323-339.

Johnson S., McMillan J., Woodruff C. (2000) Entrepreneurs and the ordering of institutional reform. Economics of Transition, vol. 8, no 1, pp. 1-36.

Kihlgren A. (2003) Small business in Russia - factors that slowed its development: An analysis. Communist and Post-Communist Studies, vol. 36, no 2, pp. 193-207.

Kirzner I.M. (1973) Competition and Entrepreneurship, Chicago; London: University of Chicago Press.

Kontovorich V. (1999) Has new business creation in Russia come to a halt? Journal of Business Venturing, vol. 14, no 5-6, pp. 451-460.

Kornai J. (1992) The Rise of the Private Sector, "The Socialist System", Princeton: Princeton University Press.

Kornai J. (2006) The great transformation of Central Eastern Europe. Economics of Transition, vol. 14, no 2, pp. 207-244.

Korosteleva J. (2014) Analytical Report on GEM in CEECs (GRINCOH Working Paper no 3.08.1), Brussels: European Commission. Available at: http://www.grincoh.eu/media/serie_3_knowledge_innovation_ technolog/grincoh_wp_3.08.1_korosteleva.pdf, accessed 15.04.2017.

Lafuente E., Vaillant Y. (2013) Age driven influence of role-models on entrepreneurship in a transition economy. Journal of Small Business and Enterprise Development, vol. 20, no 1, pp. 181-203.

Manolova T., Eunni R., Gyoshev B. (2008) Institutional environments for entrepreneurship: Evidence from emerging economies in Eastern Europe. Entrepreneurship Theory and Practice, vol. 32, no 1, pp. 203-218.

McMillan J., Woodruff C. (2002) The central role of entrepreneurs in transition economies. Journal of Economic Perspectives, vol. 16, no 3, pp. 153-170. 
Nelson R.R. (1993) National Innovation Systems: A Comparative Analysis, Oxford: Oxford University Press.

North D.C., Wallis J.J., Weingast B.R. (2009) Violence and social orders: A conceptual framework for interpreting recorded human history, Cambridge: Cambridge University Press.

Obraztsova O., Chepurenko A. (2010) Entrepreneurship and socio-economic development in cross-countries analysis. Strategic Entrepreneurship - The Promise for Future Entrepreneurship, Family Business and SME Research (eds. U. Fueglistaller, T. Volery, W. Weber), St. Gallen: KMU-HSG.

Ovaska T., Sobel R.S. (2005) Entrepreneurship in post-socialist economies. Journal of Private Enterprise, vol. 21, no 1 , pp. 8-28.

Puffer S., McCarthy D. (2001) Navigating the hostile maze: A framework for Russian entrepreneurship. The Academy of Management Executive, vol. 15, no 4, pp. 24-38.

Raiser M., Rousso A., Steves F. (2003) Trust in transition: Cross-country and firm evidence (EBRD Working Paper no 82), London: European Bank for Reconstruction and Development.

Rehn A., Taalas S. (2004) Znakomstva i svyazi (Acquaintances and connections): Blat, the Soviet Union, and mundane entrepreneurship. Entrepreneurship and Regional Development, vol. 16, no 3, pp. 235-250.

Reynolds P., Bosma N., Autio E., Hunt S., de Bono N., Servais I., Lopez-Garcia P., Chin N. (2005) Global Entrepreneurship Monitor: Data Collection Design and Implementation 1998-2003, Small Business Economics, vol. 24, no 3, pp. 205-231.

Rona-Tas A., Sagi M. (2005) Entrepreneurship and Self-Employment in Transition Economies. Entrepreneurship Research in the Sociology of Work (ed. L.A. Keister), vol. 15, Bingley: Emerald Publishing, pp. 279-310.

Sachs J.D. (1996) The transition at mid decade. American Economic Review, vol. 86, no 2, pp. 128-133.

Sauka A., Welter F. (2007) Productive, unproductive and destructive entrepreneurship in an advanced transition setting: The example of Latvian small enterprises. Empirical Entrepreneurship in Europe: New Perspectives (eds. M. Dowling, J. Schmude), Cheltenham, UK; Northampton, MA: Edward Elgar, pp. 87-105.

Scase R. (1997) The role of small businesses in the economic transformation of Eastern Europe: Real but relatively unimportant. International Small Business Journal, vol. 16, no 1, pp.113-121.

Scase R. (2000) Entrepreneurship and Proprietorship in Transition: Policy Implications for the Small-and Medium-size Enterprise Sector, Helsinki: United Nations University World Institute for Development Economics Research.

Scase R. (2003) Entrepreneurship and Proprietorship in Transition: Policy Implications for the SME Sector. Small and Medium Enterprises in Transitional Economies (eds. R. McIntyre, B. Dallago), London: Palgrave Macmillan, pp. 64-77.

Schillo S., Persault J. (2016) Entrepreneurial readiness in the context of national systems of entrepreneurship. Small Business Economics, vol. 46, no 4, pp. 619-637.

Shane S., Locke E., Collins C.J. (2003) Entrepreneurial motivation. Human Resource Management Review, vol. 13, no 2, pp. 257-280.

Smallbone D., Welter F. (2002) The distinctiveness of entrepreneurship in transition economies. Small Business Economics, vol. 16, no 4, pp. 249-262.

Spicer A., McDermott G. A., Kogut B. (2000) Entrepreneurship and privatization in Central Europe: The tenuous balance between destruction and creation. Academy of Management Review, vol. 25, no 3, pp. 630-649.

Szerb L., Trumbull W. (2015) Entrepreneurship and transition in the European transition countries. Is Transition Complete? Paper presented at the ERSA - European Regional Science Association Congress 2015, 25-28 August 2015, Lisbon, Portugal. DOI: 10.1002/jsc.2051.

van der Zwan P., Verheul I., Thurik R. (2011) The entrepreneurial ladder in transition and non-transition economies. Entrepreneurship Research Journal, vol. 1, no 2, pp. 1-20.

Volkov V. (2012) Silovoe predprinimatel'stvo, XXI vek: ekonomiko-sotsiologicheskii analiz [Strong entrepreneurship, XXI century: Economic and sociological analysis], Saint-Petersburgh: Publishing House of the European University in St. Petersburg.

WEF (2015) Leveraging Entrepreneurial Ambition and Innovation: A Global Perspective on Entrepreneurship, Competitiveness and Development, Davos: World Economic Forum. Available at: httpwww3.weforum. orgdocsWEFUSA_EntrepreneurialInnovation_Report.pdf, accessed 12.11.2016.

Welter F. (2005) Entrepreneurial Behaviour in Differing Environments. Local Heroes in the Global Village (eds. D.B. Audretsch, H. Grimm, C.W. Wessner), vol. 7, New York: Springer, pp. 93-112.

Welter F. (2011) Contextualizing entrepreneurship - conceptual challenges and ways forward. Entrepreneurship Theory and Practice, vol. 35, no 1, pp. 165-184.

Welter F., Kautonen T., Chepurenko A., Malieva E., Venesaar U. (2005) Trust environments and entrepreneurial behavior - exploratory evidence from Estonia, Germany and Russia. Journal of Enterprising Culture, vol. 12, no 4, pp. 327-349.

Welter F., Smallbone D. (2011a) Handbook of research on entrepreneurship policies in Central and Eastern Europe, Cheltenham: Edward Elgar.

Welter F., Smallbone D. (2011b) Institutional perspectives on entrepreneurial behavior in challenging environments. Journal of Small Business Management, vol. 49, no 1, pp. 107-125.

Williams C.C. (2008) Beyond necessity-driven versus opportunity-driven entrepreneurship: A study of informal entrepreneurs in England, Russia and Ukraine. International Journal of Entrepreneurship and Innovation, vol. 9, no 3, pp. 157-165. 


\title{
From Entrepreneurial Aspirations to Founding a Business: The Case of Russian Students
}

\author{
Karina Bogatyreva ${ }^{a}$ \\ Assistant Professor, k.bogatyreva@gsom.pu.ru \\ Galina Shirokova ${ }^{\text {a;b }}$ \\ Professor; and Chief Researcher at Chair of Management, shirokova@gsom.pu.ru \\ ${ }^{\text {a }}$ Graduate School of Management, Saint-Petersburg University, 3 Volkhovsky pereulok, St. Petersburg 199004, \\ Russian Federation. \\ b School of Economics and Management, Far Eastern Federal University, 8, Sukhanova str., Vladivostok 690091, \\ Russian Federation.
}

\begin{abstract}
$\mathrm{T}$

The formulation of entrepreneurial aspirations represents one of the key stages of the entrepreneurial process. In practice, however, not every declared intention is eventually translated into a viable enterprise, creating the phenomenon of the intention-action gap. This study is based upon the key principles of embeddedness perspective and the theory of planned behavior, considering a variety of factors that are able to increase or diminish the probability of an actual shift from entrepreneurial intentions to concrete start-up activities. These factors include the presence of a family business, support from

a university entrepreneurial environment, and the level of development of regional entrepreneurial institutions. An analysis of data on 4,484 students from 32 Russian universities gathered over the course of the international project, the Global University Entrepreneurial Spirit Students' Survey (GUESSS), in 2013-2014 revealed a negative correlation between a family business and the probability of a potential entrepreneur's shift from entrepreneurial aspirations to the actual creation of a startup enterprise. The development of regional entrepreneurial institutions, on the other hand, exhibits a positive link.
\end{abstract}

\section{Keywords:}

entrepreneurial intention;

intention-action gap;

student entrepreneurship;

small and medium business in Russia;

GUESSS.

Citation: Bogatyreva K., Shirokova G. (2017) From

Entrepreneurial Aspirations to Founding a Business:

The Case of Russian Students. Foresight and STI

Governance, vol. 11, no 3, pp. 25-36. DOI: 10.17323/2500-

2597.2017.3.25.36 
$\mathrm{T}$ he positions small and medium enterprises (SME) currently hold in the Russian economy can be described as weak, which significantly hinders the country's overall development. SME's share of the total turnover of goods and services is $25.4 \%$, which is quite low compared with developed nations [Romanovskaya, 2015]. In 2015, the Russian government included support for small and medium enterprises in its package of anti-crisis measures [World Bank, 2015]. A specific form of such support is promoting careers in entrepreneurship among young Russians and creating conditions that would encourage them to set up and run their own companies [Karpunina et al., 2014]. Students are a particularly promising group in this respect [Shchegolev, Nikolaev, 2014]. Student entrepreneurship could promote young people's integration into the business environment, and step up economic activity of the country's able-bodied population [Khairetdinova, 2014].

Of 4,484 students of 32 Russian universities surveyed in 2013-2014 as part of the international project Global University Entrepreneurial Spirit Students' Survey (GUESSS) ${ }^{1}$, about 53\% have stated their intentions to start their own business within five years following graduation [Shirokova et al., 2015a]. However, entrepreneurial aspirations as such do not always translate into the actual implementation of a business idea - not by far. The phenomenon of the intention-action gap, i.e., failing to implement previous intentions, commands significant interest from psychologists (see e.g. [Ajzen, Czasch, Flood, 2009; Armitage, Conner, 2001; Orbell, Sheeran, 1998; Sheeran, 2002; Sniehotta et al., 2005]). However, very few relevant studies were conducted by researchers specializing in entrepreneurship (see e.g. [Kautonen et al., 2013; Shirokova et al., 2015b; van Gelderen et al., 2015]). No such studies were found for Russia at all. Identifying factors which affect the probability (its increase or decrease) of moving on from entrepreneurial intentions to actually establishing a company seems to be a particularly relevant objective at this stage [Liñán, Fayolle, 2015].

Entrepreneurial intentions and their implementation largely depend on nascent entrepreneurs' personal characteristics [Liñán, Fayolle, 2015]. The external environment also plays a role, since it affects individuals behavior including their involvement in entrepreneurship [Rauch, 2014]. This hypothesis is based on the "embeddedness perspective" concept which links people's actions to the system of social relations and the context in which they are immersed [Welter, 2013; Granovetter, 1985; Welter, 2011]. The goal of our paper is to assess the impact of factors affecting, at various levels, the context of Russian university students' moving on from entrepreneurial intentions to actually taking action on starting a new business. The originality of the study lies in its further elaboration of the planned behavior theory [Ajzen, 1991] by identifying the reasons of such a transition's success. The study also considers the applicability of the embeddedness perspective for analyzing the role of various parameters of the environment in which entrepreneurship takes place. Finally, the traditional scope for applying an institutional approach to studying entrepreneurship was extended by considering the role of the regional institutional environment in the entrepreneurial intention-action transition.

The first section of the paper presents the theoretical basis of the study and formulates the hypotheses. Next comes a description of the applied methodology. The third section describes the results of the data analysis, and the fourth contains a discussion about them. The final section formulates our main conclusions, points out the limitations of the study, and outlines areas for future research in this field.

\section{Theoretical basis and hypotheses of the study}

According to the theory of planned behavior [Ajzen, 1991], targeted action by individuals is preceded by the emergence of their intentions, which in turn are affected by the following factors:

- Personal attitude toward the relevant activities;

- Perceived behavioral control based on the individual's perception of how easy or difficult implementing their plans is going to be;

- Subjective norms defined by public opinion, which can either encourage one to or discourage one an individual from implementing said plans.

Intentions serve as an intermediate link between the above factors, a bridge to implementing action and achieving the desired objectives [Armitage, Conner, 2001].

The mechanism of intention formation remained the focus of attention of researchers specializing in entrepreneurship for a long time (see e.g. [Bird, 1988; Heuer, Liñán, 2013; Krueger, 2009; Liñán, RodriguezCohard, 2015; Shapero, Sokol, 1982; Schlaegel, Koenig, 2014; Shook, Bratianu, 2003]). The correlation between entrepreneurial intentions and the actual action they take empirically confirms the provisions of the theory of planned behavior [Kautonen et al., 2013; 2015; Liñán, Fayolle, 2015; van Gelderen et al., 2015]. For student entrepreneurs, this correlation is just as valid as it is for older age groups [Shirokova et al., 2015a]. Being in a career choice situation forces students who intend to become entrepreneurs to

\footnotetext{
For more details about the project see: http://www.guesssurvey.org/, last accessed on 26.08.2016.
} 
start doing something about it while they still continue their studies, to lay the groundwork for the future growth of their companies.

At the same time, the correlation between intention and action is rather weak. Previous studies show that the presence of the former explains no more than $30 \%$ of the resulting attribute's variation - i.e. the implementation of actual action [Armitage, Conner, 2001; Sheeran, 2002]. These results indicate the situational nature of the intention-action transformation, and the presence of factors promoting or inhibiting this process. According to the embeddedness theory [Granovetter, 1985], the system of social relations and the context in which individuals find themselves significantly affect their behavior. Regarding entrepreneurship, it means that the probability of moving on from intention to action on starting a business may depend on specific characteristics of the individual's environment. In our study, we propose and put forward a hypothesis that, for student entrepreneurs, this transition is embedded in the context of the family they come from, the university environment they are immersed in, and the region where they live and study.

\section{Coming from a business-owning family}

Coming from a business-owning family may largely pre-determine students' career choices, prompting them to follow their parents' career path and start their own business [Laspita et al., 2012]. Entrepreneurial parents may become role models for those students [Chlosta et al., 2012]. Also, people who come from a business-owning family tend to possess a higher quality of human capital due to the experience, knowledge, and skills necessary for running a business picked up from their parents, among other things, by participating in the management of the family firm [Lentz, Laband, 1990; Mueller, 2006]. Such students often feel more confident moving from entrepreneurial aspirations to action, which ultimately increases the likelihood of their creating a new company [Shirokova et al., 2015b].

Besides developing human capital, business owners may help their children to find and obtain the necessary resources for realizing their entrepreneurial intentions. Specifically, business owning parents serve as a source of financial support for their children [Dunn, Holtz-Eakin, 2000] and provide them with access to their social capital, i.e., the network of partners, suppliers, investors, and customers [Laspita et al., 2012]. The aforementioned early-stage advantages of people coming from business-owning families over other nascent entrepreneurs help them successfully complete the transition from intention to starting a business. No less important is the emotional support from the older generation: approval or encouragement is another important incentive to actually become an entrepreneur [Zanakis et al., 2012]. Russian entrepreneurs note the special role family support plays at the stage of business creation and initial development [Djankov et al., 2006; McCarthy et al., 2010]. As was already established, believing one's knowledge and skills to be sufficient to run a business and possessing the required practical experience serve as major prerequisites for the emergence of relevant intentions in Russia [Aleksandrova, Verkhovskaya, 2015]. All these factors can be presumed also to be significant for people coming from a business-owning family, which may lead to not only the formation of corresponding intentions by Russian students, but their taking direct action to implement them. The above arguments allow one to put forward the following hypothesis:

H1: The positive relationship between entrepreneurial intentions and start-up activities will be stronger for Russian students with a family entrepreneurial background.

\section{University entrepreneurial environment}

Apart from the family environment, the creation of one's own businesses by students is also affected by the university context [Shirokova et al., 2015b]. Potential student entrepreneurs spend most of their time at their place of study, so the academic environment significantly influences their disposition towards particular activities. Specifically, students' entrepreneurial intentions and their subsequent transformation into action may be affected by the university's initiatives aimed at promoting student entrepreneurship [Bae et al., 2014; Shirokova et al., 2015; Zhang et al., 2014].

Such initiatives include certain courses, e.g., entrepreneurship courses and seminars designed to give students the basic knowledge and skills required for running a business [Shirokova et al., 2014; Klofsten, 2000]. Educational initiatives are aimed at improving the quality of the crucial resource - human capital, to compensate for students' lack of experience as early-stage entrepreneurs [Zhao et al., 2005]. University-based business incubators and accelerators, whose residents receive the opportunity to quickly turn their ideas into actual start-ups, find investors, and seek out expert support, also play an important role in transforming entrepreneurial aspirations into action [Hughes et al., 2007]. The university may turn into a source of social capital for young entrepreneurs, through mentoring programs, seminars and training events with the participation of experienced businessmen, designed not only to provide useful knowledge and skills, but also to expand the students' network of business contacts [Nielsen, Lassen, 
2012; Davidsson, Honig, 2003; De Clercq, Arenius, 2006; Morales-Gualdron, Roig, 2005; Sequeira et al., 2007]. Finally, universities can provide access to financial capital through special funding programs for student startups [Parker, Belghitar, 2006].

In present-day Russia, the need to promote the entrepreneurial aspect of universities' activities is universally accepted [Shchegolev, Nikolaev, 2014]. Many universities run successful business incubators which help nascent entrepreneurs at the project launch stage. In particular, such universities include National Research University Higher School of Economics, Lomonosov Moscow State University, Financial University under the Government of the Russian Federation, St. Petersburg National Research University of Information Technologies, Mechanics and Optics, and others. The requirements for graduates are also changing: along with basic and specialized disciplines, a special effort is being made to promote specific personality traits such as initiative, leadership, enterprise, and the ability to generate new ideas and realize them [Zakharova, 2013; Reznik, Ponomarenko, 2010]. Taken together, these traits can significantly affect the emergence of entrepreneurial intentions and their subsequent implementation.

Today's educational programs and extracurricular activities increasingly often include business case studies, computerized business simulations, business plan development, workshops and master classes led by expert entrepreneurs, and targeted educational modules on entrepreneurship [Konyukhova, 2014; Shchegolev, Nikolaev, 2014; Shcherbakova, 2012]. Students participate in business plan competitions, which allows them not only to test their ideas and receive feedback from experts and experienced entrepreneurs but also, if they win, secure financial support for further development. In particular, such annual events include the student business plan competition held by the Graduate School of Management of St. Petersburg University, or the "My First Business" project by National University of Science and Technology MISiS. All of the above can be summarized in the following hypothesis:

H2: The positive relationship between entrepreneurial intentions and start-up activities will be stronger for Russian students coming from universities with a favorable entrepreneurial environment.

\section{Regional institutional environment}

Along with the family and university contexts, the emergence of entrepreneurial aspirations, and the likelihood of taking practical steps toward realizing them can also be affected by the external institutional conditions. The latter are defined by the institutions' specific features, which either promote or hinder the development of entrepreneurship in a region. This factor is particularly relevant in Russia, which is a country with significant disparities in many regions' entrepreneurial infrastructure, which directly affect small business development on a national scale [Saidullaev, 2015].

The institutional approach to studying entrepreneurship presumes that institutions set conditions under which entrepreneurs operate and make decisions on starting and running their businesses [Bruton et al., 2010; Peng, 2003]. These conditions may affect people's individual perception of their prospects for starting a business, and their willingness to move forward and take action to implement their entrepreneurial intentions [Kibler, 2013].

Entrepreneurial behavior is embedded into the institutional context and affected by a number of encouraging or discouraging factors [Welter, 2013; Welter, 2011; Welter, Smallbone, 2011] such as regulatory initiatives of the regional authorities [Stenholm et al., 2013]. Initiatives of this kind include regional small business and entrepreneurship promotion programs whose large-scale implementation increases the probability of nascent entrepreneurs' moving from intention to action and therefore investing their time, resources and efforts in setting up a company. However, low participation in such programs has been observed in most Russian regions and combined with other factors affecting regional development may have a more powerful negative impact upon this process. Other factors in this case include the state of the legal environment, administrative norms and the level of their enforcement in the region, and, finally, the level of corruption.

As was demonstrated in a recent study [Costa, Mainardes, 2016], the perceived level of corruption negatively affects the emergence of entrepreneurial intentions. It probably has the same effect on the transition from intentions to action. This is particularly critical for Russia, which holds $119^{\text {th }}$ place out of 167 in the perceived corruption ranking [Transparency International, 2015]. According to the European Bank for Reconstruction and Development (EBRD), in a number of Russian regions the high level of corruption is perceived as one of the largest barriers hindering business development [EBRD, 2012]. Various aspects of regional socioeconomic development also seem to be quite important, such as access to financial resources and human capital, i.e., the availability of personnel with particular qualifications and specializations; the size of market entry barriers created by factors such as the level and severity of competition and the presence of large firms in the region; effective demand; the availability of transport; access to technology and equipment; S\&T potential; information environment; resource self-sufficiency; the level of development of innovative territorial clusters, regional "business catalysts", etc. [Kutsenko, 2015; Makarov, Ugnich, 2015; Pavlov, 2008; Fritsch, Storey, 2014]. The above parameters significantly 
vary in different Russian regions [EBRD, 2012], as does their effect on the emergence of entrepreneurial intentions and the transition to action aimed at starting one's own business.

Keeping in mind the above arguments, the following hypothesis can be formulated:

H3: The positive relationship between entrepreneurial intentions and start-up activities will be stronger for Russian students coming from regions with a favorable institutional environment with respect to entrepreneurship.

A generalized theoretical model of the study is presented in Figure 1.

\section{Methodology of the study \\ Description of the sample}

The international GUESSS project (data collected in its framework provided the empirical basis of our study) was launched in 2003 by the Swiss Research Institute of Small Business and Entrepreneurship of the University of St. Gallen (KMU-HSG). Its objective was to study students' entrepreneurial aspirations taking into account such factors as family support, the university environment, and the socio-cultural context. In the scope of the GUESSS project, data is collected every two years with international coverage of students specializing in different fields of study. In 2013-2014, 109,026 students were surveyed at 759 universities in 34 countries. Russia has participated in the project since 2011. The national operator of the project is the Graduate School of Management of St. Petersburg University, which is responsible for recruiting Russian universities and the translation and distribution of questionnaires among the participants. Between the start of October and the end of December 2013, 4,578 Russian students were surveyed at 32 Russian universities ${ }^{2}$.

For the purposes of this study, students who came to Russia on exchange programs and those studying as part of continuing professional education programs were excluded from the general sample. The final sample comprised 4,484 students from 19 Russian regions.

\section{Measuring variables}

Dependent variable. Since our study is focused on the transition from entrepreneurial aspirations to taking action on starting one's own business, a binary variable was chosen as the resulting characteristic of the model. It takes the value of 0 if the student did not do anything to establish a company, and 1 if even a single practical step was actually taken. The list of such steps based on the international projects "Panel Study of Entrepreneurial Dynamics" (PSED) and "Global Entrepreneurship Monitor" (GEM) included the following: "Discussed product or business idea with potential customers", "Collected information about markets or competitors", "Has written up a business plan", "Launched product/service development", "Started marketing or promotion campaigns", "Purchased materials, equipment or machinery for the business", "Attempted to obtain external funding", "Applied for a patent, copyright or trademark", "Registered the company", and "Sold the product or service".

Independent variable. Students' entrepreneurial intentions were measured using the scale presented in [Liñán, Chen, 2009]. The respondents were asked to assess the following statements on a scale of 1

Figure 1. Theoretical model of the study

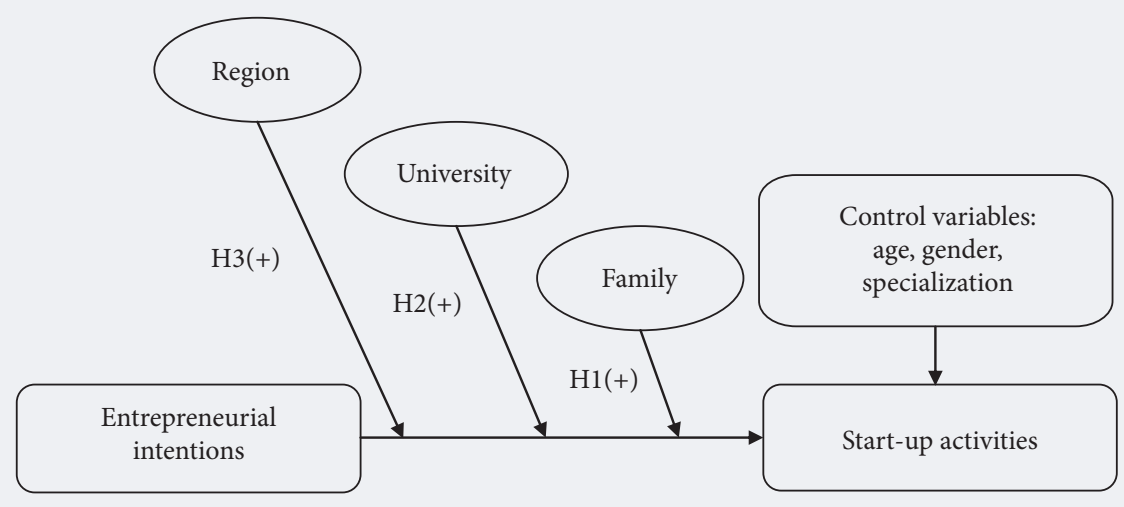

Source: compiled by the authors.

\footnotetext{
2 For more about the implementation of the GUESSS project in Russia in 2013-2014 see: [Shirokova et al., 2015b].
} 
(totally disagree) to 7 (completely agree) "I am ready to do anything to become an entrepreneur", "My professional goal is to become an entrepreneur", "I will make every effort to start and run my own firm", "I am determined to create a firm in the future", "I have very seriously thought of starting a firm", and "I have serious intentions of starting a firm someday". On the basis of the answers, the average strength of each student's entrepreneurial aspirations was calculated. The missing values were replaced with the average ones for the university, since the number of omissions did not exceed $7 \%$ of the total sample. The distribution of missing values by basic demographic characteristics (gender, age, profile of studies, family status) on average matched the general sample's trends, without any obvious outliers.

Moderators. For the purposes of this study, the following moderators of the relationship between students' intentions and their actual involvement in business activities were used: coming from a business-owning family; the university environment; and the level of development of the regional institutions responsible for promoting entrepreneurship.

Family entrepreneurial background. This variable takes the value of 1 if at least one of the student's parents is an entrepreneur, and 0 if that is not the case.

University entrepreneurial environment was assessed by students using a scale of 1 (totally disagree) to 7 (completely agree) to evaluate the following statements: "The atmosphere at my university inspired me to develop ideas for a new business", "There is a favorable climate for becoming an entrepreneur at my university", "At my university, students are encouraged to engage in entrepreneurial activities" [Franke, Lüthje, 2004; Geissler, 2013]. Missing values were substituted with averages for the university.

The level of development of regional institutions was operationalized using data collected by the analytical center of the Russian Small Business and Entrepreneurship Support Bank (MSP Bank, Inc.) in 20122013 through a survey entitled "Small and Medium Business Conditions Index" [MSP Bank, 2014]. The objective of the project was to assess business conditions in Russian regions on the basis of Rosstat data and the results of studies on the Russian entrepreneurial environment. The following indicators were used:

1) Production factors: access to necessary resources such as financial and human capital, and regional entrepreneurship infrastructure;

2) Demand and competition: market entry barriers, effective demand;

3) Regulatory impact: support of entrepreneurship provided by the regional authorities;

4) Macroeconomic risks: inflation, regional budget balance, the region's revenues/expenditures ratio, the share of expenditures in gross regional product;

5) Risks related to crime, excessive administrative barriers, and corruption.

The MSP Bank's rating ranked Russian regions by each of the above groups of factors depending on the "grade" they received (good, satisfactory, or poor). We converted these qualitative indicators into quantitative ones by assigning the following values to the assessments of the factor groups: $1=$ poor, 2 = satisfactory, and 3 = good. Next, the level of development of the institutions potentially capable of promoting or hindering entrepreneurship was calculated for each region. The list of regions, the number of the respondents covered by the GUESSS project, and the assessments of the institutional environment's development are presented in Table 1.

Control variables. Students' personal characteristics (such as gender and age) can significantly affect the emergence of entrepreneurial intentions and, as a consequence, their willingness to take relevant action [Haus et al., 2013; Levesque, Minniti, 2006]; accordingly, these variables were included in the model as control variables. The variable "Age" was measured in years; the missing values were replaced with the averages in accordance with the approach proposed in [Afifi, Elashoff, 1966]. The variable "Gender" is a binary variable: it takes the value of 1 for female and 0 for male students. In addition to socio-demographic characteristics, students' major specialization was also taken into account [Kolverei, Moen, 1997] given that students studying economics or business/management can be expected to be more inclined towards entrepreneurship. This variable is also binary, and takes the value of 1 if the student specializes in the above fields, and 0 in all other cases.

We tested the reliability of latent variables' values in the model. Cronbach's alpha for entrepreneurial intentions was 0.95 , and for university entrepreneurial environment it was 0.88 , which is above the recommended value of 0.7 and therefore indicates the inherent compliance of the characteristic chosen to describe the above theoretical constructs [Cronbach, 1951]. Descriptive statistics for the variables and the correlation matrix are presented in Tables 2 and 3.

\section{Data analysis results}

The study's hypotheses were tested by evaluating a three-step logistic regression. To exclude heteroscedasticity, robust standard errors were used at all three stages of the evaluation. The results of testing the hypotheses are presented in Table 4. 


\section{Table 1. Assessment of Russian regional institutional environments' development (2014)}

\begin{tabular}{|c|c|c|c|c|c|c|c|}
\hline Регион & $\begin{array}{c}\text { Number of } \\
\text { respondents }\end{array}$ & $\begin{array}{l}\text { Production } \\
\text { factors }\end{array}$ & $\begin{array}{l}\text { Demand and } \\
\text { competition }\end{array}$ & $\begin{array}{c}\text { Regulatory } \\
\text { impact }\end{array}$ & $\begin{array}{c}\text { Macroeconomic } \\
\text { risks }\end{array}$ & $\begin{array}{c}\text { Administrative } \\
\text { barriers and } \\
\text { corruption }\end{array}$ & Total \\
\hline Altai Republic & 38 & 3 & 1 & 2 & 1 & 2 & 9 \\
\hline Astrakhan Region & 55 & 1 & 1 & 1 & 3 & 2 & 8 \\
\hline Bryansk Region & 123 & 1 & 2 & 2 & 1 & 2 & 8 \\
\hline Volgograd Region & 101 & 1 & 2 & 2 & 2 & 1 & 8 \\
\hline Voronezh Region & 90 & 2 & 2 & 2 & 2 & 3 & 11 \\
\hline Irkutsk Region & 142 & 1 & 2 & 2 & 3 & 3 & 11 \\
\hline Krasnoyarsk Region & 90 & 2 & 2 & 1 & 1 & 2 & 8 \\
\hline Moscow & 540 & 2 & 3 & 3 & 2 & 2 & 12 \\
\hline Novgorod Region & 211 & 2 & 2 & 2 & 3 & 2 & 11 \\
\hline Novosibirsk Region & 82 & 2 & 2 & 2 & 3 & 2 & 11 \\
\hline Perm Region & 225 & 1 & 3 & 3 & 2 & 1 & 10 \\
\hline Primorsky Region & 186 & 2 & 1 & 1 & 2 & 3 & 9 \\
\hline $\begin{array}{l}\text { Republic of Sakha } \\
\text { (Yakutia) }\end{array}$ & 222 & 3 & 2 & 3 & 3 & 3 & 14 \\
\hline Republic of Tatarstan & 469 & 2 & 3 & 3 & 3 & 3 & 14 \\
\hline Rostov Region & 83 & 1 & 2 & 3 & 3 & 3 & 12 \\
\hline St. Petersburg & 1026 & 2 & 3 & 2 & 3 & 3 & 13 \\
\hline Sverdlovsk Region & 42 & 1 & 3 & 2 & 2 & 2 & 10 \\
\hline Stavropol Region & 635 & 1 & 2 & 1 & 2 & 2 & 8 \\
\hline Tomsk Region & 97 & 2 & 3 & 2 & 2 & 2 & 11 \\
\hline
\end{tabular}

At the first stage of the study, the control variables' effects were measured (Model 1), and a positive correlation was discovered between students' age $(\mathrm{b}=0.038, \mathrm{p}<0.05)$ and actual steps taken to start their own business. It was established that women were less likely than men to realize their entrepreneurial intentions $(b=-0.981, p<0.001)$. Finally, students specializing in economics or business management demonstrated a more pronounced inclination to implement their business ideas compared with all others $(\mathrm{b}=0.487, \mathrm{p}<0.001)$.

At the second stage, the main effects were added to the model (Model 2) and a direct relationship was found between students' intentions and participation in entrepreneurial activities $(b=0.503, p<0.001)$. Also, the positive effect of a family entrepreneurial background was established $(b=0.418, p<0.001)$, as was the negative influence of the university entrepreneurial environment $(b=-0.057, p<0.05)$.

At the third stage, the testing of moderation effects (Model 3), after adding the moderators, the assessment of the regression coefficient "Entrepreneurial intentions" variable ceased to be statistically significant, which implies that the nature of transition from entrepreneurial intentions to action is situational. The results of empirical testing revealed that one of the factors promoting this process was the level of the development of the regional institutional environment $(b=0.042, p<0.05)$, which confirms hypothesis $\mathrm{H} 3$. The coefficient of the variable reflecting students' family entrepreneurial background turned out to be negative, i.e., students whose parents are entrepreneurs are less likely to implement their own business initiatives $(b=-0.102, p<0.1)$, which refutes hypothesis $\mathrm{H} 1$. The regression coefficient of university

Table 2. Descriptive statistics

\begin{tabular}{|c|c|c|c|c|}
\hline Variable & Mean value & Standard deviation & Min & Max \\
\hline 1. Involvement in start-up activities & - & - & 0 & 1 \\
\hline 2. Entrepreneurial intentions & 4.60 & 1.62 & 1 & 7 \\
\hline 3. Family entrepreneurial background & - & - & 0 & 1 \\
\hline 4. University entrepreneurial environment & 4.43 & 1.57 & 1 & 7 \\
\hline 5. Regional institutions & 9.54 & 1.78 & 6 & 12 \\
\hline 6. Age & 20.14 & 1.86 & 17 & 40 \\
\hline 7. Gender & - & - & 0 & 1 \\
\hline 8. Specialization & - & - & 0 & 1 \\
\hline
\end{tabular}


Table 3. Correlation matrix

\begin{tabular}{|c|c|c|c|c|c|c|c|c|}
\hline Variables & 1 & 2 & 3 & 4 & 5 & 6 & 7 & 8 \\
\hline 1. Involvement in start-up activities & 1 & & & & & & & \\
\hline 2. Entrepreneurial intentions & $0.254^{* *}$ & 1 & & & & & & \\
\hline 3. Family entrepreneurial background & $0.010^{\star *}$ & $0.099^{* *}$ & 1 & & & & & \\
\hline 4. University entrepreneurial environment & $0.031^{\star}$ & 0.266 & -0.004 & 1 & & & & \\
\hline 5. Regional institutions & -0.005 & $-0.067^{\star *}$ & -0.015 & $-0.031^{\star}$ & 1 & & & \\
\hline 6. Age & $0.041^{*}$ & -0.001 & $-0.039^{*}$ & $-0.033^{\star}$ & $-0.031^{\star}$ & 1 & & \\
\hline 7. Gender & $-0.188^{\star *}$ & -0.028 & $-0.028 \dagger$ & 0.019 & $-0.048^{*}$ & $-0.052^{\star *}$ & 1 & \\
\hline 8. Specialization & $0.089^{* *}$ & $0.064^{* *}$ & $0.064^{\star *}$ & $0.094^{\star *}$ & $0.065^{\star *}$ & $0.038^{*}$ & 0.002 & 1 \\
\hline \multicolumn{9}{|c|}{$\begin{array}{l}\dagger \mathrm{p}<0.1 ;{ }^{*} \mathrm{p}<0.05 ;{ }^{* *} \mathrm{p}<0.001 \text { ( } 2 \text {-tailed). } \\
\text { Note: A point biserial correlation coefficient was used to calculate the correlation between variables if one of them was binary; in all other cases, the Pearson } \\
\text { correlation coefficient was used. } \\
\text { Source: compiled by the authors. }\end{array}$} \\
\hline
\end{tabular}

entrepreneurial environment turned out to be insignificant, which means that hypothesis $\mathrm{H} 2$ was not confirmed.

\section{Discussion}

The theory of planned behavior [Ajzen, 1991] implies a direct relationship between intentions and the actions taken to implement them. The results of our study confirmed the validity of this theory regarding the transition from entrepreneurial aspirations to starting and running one's own business by early-stage entrepreneurs - the students of Russian universities. This intuitively reliable conclusion corresponds with most of the relevant studies [Kautonen et al., 2013, 2015; Liñán, Fayolle, 2015; Shirokova et al., 2015; van Gelderen et al., 2015]. At the same time, the theory of planned behavior (which was developed primarily to explain the mechanism of intention formation) does not fully explain the gap between intentions and action, i.e., the situations where declared intentions were not actually realized. Our results show that the transition from the former to the latter is affected by the context, by factors that can either increase or reduce the probability of such a transition.

Students who are considering a career in entrepreneurship and come from business-owning families are rather less likely to realize such intentions. This finding contradicts our initial hypothesis about the role of family business in this process. There may be several possible explanations. Firstly, people who come

Table 4. Regression analysis results

\begin{tabular}{|c|c|c|c|}
\hline Variables & Model 1 & Model 2 & Model 3 \\
\hline \multicolumn{4}{|c|}{ Control variables } \\
\hline Age & $0.038^{*}$ & $0.064^{\star *}$ & $0.062^{\star *}$ \\
\hline Gender & $-0.981^{\star * \star}$ & $-0.954^{\star \star \star}$ & $-0.956^{\star * \star}$ \\
\hline Specialization & $0.487^{\star * *}$ & $0.319^{* * *}$ & $0.312^{\star * *}$ \\
\hline \multicolumn{4}{|c|}{ Main effects } \\
\hline Entrepreneurial intentions & & $0.503^{\star \star \star}$ & 0.201 \\
\hline Family entrepreneurial background & & $0.418^{\star * \star}$ & $0.973^{\star *}$ \\
\hline University entrepreneurial environment & & $-0.057^{\star}$ & 0.031 \\
\hline Regional institutions & & -0.002 & $-0.227^{\star *}$ \\
\hline \multicolumn{4}{|c|}{ Moderating effects } \\
\hline Entrepreneurial intentions X family entrepreneurial background & & & $-0.102 \dagger$ \\
\hline Entrepreneurial intentions X university entrepreneurial environment & & & -0.015 \\
\hline Entrepreneurial intentions X regional institutions & & & $0.042^{*}$ \\
\hline Constant & $-1.844^{* * *}$ & $-4.681^{\star * \star}$ & $-3.038^{* *}$ \\
\hline $\mathrm{N}$ & 4479 & 4358 & 4358 \\
\hline Prob > chi 2 & 0.000 & 0.000 & 0.000 \\
\hline Pseudo R2 & 0.045 & 0.119 & 0.121 \\
\hline
\end{tabular}


from business-owning families can realize their entrepreneurial aspirations not just by creating their own firm but also by becoming the successor to the family business. This saves such nascent entrepreneurs from taking numerous steps on their own, which may partially explain the established negative correlation between coming from a business-owning family and taking action to implement one's entrepreneurial intentions. This hypothesis is confirmed by the results of the GUESSS 2013-2014 study: the average measured value of the assessment by Russian students coming from business-owning families about their joining the family firm as a possible career path was higher than that of the international sample: 3.41 vs. 2.67, respectively [Shirokova et al., 2015b]. Another factor likely affecting the lower rate of Russian students coming from business-owning families realizing their entrepreneurial intentions may be doubts concerning the prospects of such a career in Russia, reinforced by the practical experience of their family. Russian businesses, which has to survive in a developing economy, are highly dynamic and highly aggressive [Puffer, McCarthy, 2001]. The negative business experience of family members may prompt students to abandon their entrepreneurial aspirations and pursue a career outside of entrepreneurship.

We were unable to confirm a relationship between a developed entrepreneurial environment at a student's university and the likelihood of he or she making the transition from entrepreneurial aspirations to establishing a business. Despite the obvious success of providing various kinds of support to student entrepreneurship, the overall relevant infrastructure needs further development [Karpunina et al., 2014]. An important step along this path would the adoption of the entrepreneurial university model as a target milestone [Bokov et al., 2011; Ivashchenko et al, 2014]. This model covers various areas of university activity in addition to academic initiatives, and stipulates the creation of innovation centers, the commercialization of research results, the expansion of funding sources, the promotion of an entrepreneurial culture and a good business environment, and active cooperation with members of the business community [Ivashchenko et al., 2014; Konstantinov, Filonovich, 2007; Tappaskhanova et al., 2014]. Implementing such initiatives at Russian universities would provide a significant incentive for transforming students' entrepreneurial aspirations into actual efforts at founding a firm.

Finally, we established a positive moderating effect from the level of development of the regional entrepreneurial infrastructure on the link between students' entrepreneurial intentions and actions. This is in line with the initial assumption about the effect of the local institutional context on people's business activities. As was shown in a recent study [Aleksandrova, Verkhovskaya, 2015], one of the more important factors of the latter is the positive perception of business conditions in the region. Our conclusions confirm the validity of this thesis regarding the realization of entrepreneurial intentions. Due to significantly differing business conditions across various Russian regions, SMEs are not developing evenly in the country [Gosudarstvennyi Sovet Rossiiskoi Federatsii, 2015]. Of course, the specific regional policies are affected by the nation-wide policies, and by each region's particular development goals and objectives [Gnevko, 2010]. However, as we were able to demonstrate, a regional system for providing various kinds of support to entrepreneurship via programs based on the Federal Law No. 209-FZ "On the development of small and medium entrepreneurship in the Russian Federation" of 24.07.2007, or through indirect measures to promote effective demand, combat corruption, and improve the regional macro-economic situation, could increase the number of young entrepreneurs willing to move from intentions to action, start their own businesses and contribute to an overall increase in business activity.

\section{Contribution to theory and practical significance of this study}

Our study was intended to obtain a deeper understanding of the relationship between the main components of the entrepreneurial process in Russia. It further clarifies the theory of planned behavior [Ajzen, 1991] regarding factors that could presumably affect the transition from intention to entrepreneurial action. We demonstrated the applicability of the "embeddedness" concept [Granovetter, 1985] to various kinds of people's business activities. Finally, we tried to extend the scope of applying the institutional approach to studying entrepreneurship by revealing the role of regional institutions in the conversion of entrepreneurial aspirations into relevant action in the context of emerging markets.

The conclusions made on the basis of this study could be useful to the developers of regional entrepreneurship promotion programs. In particular, we have in mind the variety of factors affecting the entrepreneurial intention-action transition, specifically the unique Russian aspects of this process. The new knowledge can also be applied in business education programs offered at Russian universities, which in the end ultimately affect the level of students' overall entrepreneurial activities.

\section{Limitations and areas for further research}

Cross-sectional data were used in our study, i.e., the strength of entrepreneurial intentions and action taken to create new businesses were measured at just one point in time - providing no opportunity to assess their dynamics. Since intentions tend to change, their explanatory function reduces with time [Sutton, 1998]; therefore, the role of various factors affecting the intention-action transition was in the 
focus of our paper. Still, a possible area for studying the link between intentions and actual entrepreneurial activities in the Russian context might be found in longitudinal studies.

In this paper, we relied on an exclusively student sample, which does not allow us to extrapolate the results for other early-stage entrepreneur groups. Another possible area for future research could be testing the factors affecting the entrepreneurial intention-action transition of members of different social groups. Also, the results of our analysis are relevant only for the Russian context. Similar studies conducted in other countries would probably discover other constellations of entrepreneurial ecosystem elements for consideration.

Finally, we attempted to measure the unidirectional links between the main elements of the business process. However, moving on from entrepreneurial intentions to action is a complex and multifaceted activity, so studying it involves the application of quantitative research techniques to fully understand all its aspects.

\section{Conclusion}

The theory of planned behavior implies a direct relationship between intentions and the steps taken to implement them. In the case of entrepreneurship, this relationship can be strengthened or weakened by a host of context-dependent factors. In our study, we used the embeddedness perspective to establish the negative effect of students' family entrepreneurial background on their transition from having business aspirations to taking relevant action, and the positive effect of the regional institutional entrepreneurial environment on this process. Our paper contributes to advancing entrepreneurship studies, and has practical value for the designers of regional business promotion programs and relevant educational initiatives.

This research was conducted with financial support from a Russian Science Foundation grant (project No. 14-18-01093).

\section{References}

Afifi A.A., Elashoff R.M. (1966) Missing Observations in Multivariate Statistics. Journal of American Statistical Association, no 61 (315), pp. 595-605.

Ajzen I. (1991) The Theory of Planned Behavior. Organizational Behavior \& Human Decision Processes, vol. 50, no 2, pp. 179-211.

Ajzen I., Czasch C., Flood M.G. (2009) From Intentions to Behavior: Implementation Intention, Commitment, and Conscientiousness. Journal of Applied Social Psychology, vol. 39, no 6, pp. 1356-1372.

Aleksandrova E.A., Verkhovskaya O.R. (2015) Predprinimatel'skie namereniya v Rossii: empiricheskii analiz [Entrepreneurial Intentions in Russia: Empirical Analysis]. Rossiiskii zhurnal menedzhmenta [Russian Management Journal], vol.13, no 2, pp. 2-26 (in Russian).

Armitage C.J., Conner M. (2001) Efficacy of the Theory of Planned Behavior: A Meta-Analytic Review. British Journal of Social Psychology, vol. 40, no 4, pp. 471-499.

Bae T.J., Qian S., Miao C., Fiet, J.O. (2014) The Relationship between Entrepreneurship Education and Entrepreneurial Intentions: A Meta-Analytic Review. Entrepreneurship Theory \& Practice, vol. 38, no 2, pp. 217-254.

Bird B.J. (1988) Implementing Entrepreneurial Ideas: The Case for Intention. Academy of Management Review, vol. 13 , no 3, pp. 442-453.

Bokov L.A., Kobzev A.V., Uvarov A.F., Shurygin Yu.A. (2011) Na puti k predprinimatel'skomu universitetu [On the Way to Entrepreneurial University]. Innovatsii [Innovations], no 4, pp. 11-17 (in Russian).

Bruton G.D., Ahlstrom D., Han-Lin L. (2010) Institutional Theory and Entrepreneurship: Where are We Now and Where do We Need to Move in the Future? Entrepreneurship: Theory \& Practice, vol. 34, no 3, pp. 421-440.

Chlosta S., Patzelt H., Klein S.B., Dormann C. (2012) Parental Role Models and the Decision to Become Selfemployed: The Moderating Effect of Personality. Small Business Economics, vol. 38, no 1, pp. 121-138.

Costa L., Mainardes E.W. (2016) The Role of Corruption and Risk Aversion in Entrepreneurial Intentions. Applied Economics Letters, vol. 23, no 4, pp. 290-293.

Cronbach L. (1951) Coefficient Alpha and the Internal Structure of Tests. Psychometrika, no 16, pp. 297-334.

Davidsson P., Honig B. (2003) The Role of Social and Human Capital among Nascent Entrepreneurs. Journal of Business Venturing, vol. 18, no 3, pp. 301-331.

De Clercq D., Arenius P. (2006) The Role of Knowledge in Business Start-Up Activities. International Small Business Journal, vol. 24, no 4, pp. 339-358.

Djankov S., Miguel E., Qian Y., Roland G., Zhuravskaya E. (2006) Entrepreneurship: First Results from Russia (CEPR Discussion Papers 5707), London: CEPR.

Dunn T., Holtz-Eakin D. (2000) Human Capital and the Transition to Self-Employment: Evidence from Intergenerational Links. Journal of Labor Economics, vol. 18, no 2, pp. 282-305.

EBRD (2012) Diversifying Russia, London: European Bank for Reconstruction and Development. Available at: http:// www.ebrd.com/news/publications/special-reports/diversifying-russia.html, accessed 18.02.2016.

Franke N., Lüthje C. (2004) Entrepreneurial Intentions of Business Students: A Benchmarking Study. International Journal of Innovation and Technology Management, vol. 1, no 3, pp. 269-288.

Fritsch M., Storey D.J. (2014) Entrepreneurship in a Regional Context: Historical Roots, Recent Developments and Future Challenges. Regional Studies, vol. 48, no 6, pp. 939-954.

Geissler M. (2013) Determinanten des Vorgründungsprozesses, Wiesbaden: Springer Fachmedien Wiesbaden.

Gnevko V.A. (ed.) (2010) Regional'nye aspekty funktsionirovaniya i razvitiya malogo predprinimatel'stva $v$ Rossii [Regional Aspects of Russian Entrepreneurship Functioning and Development], Saint-Petersburgh.: SaintPetersburgh Academy of Governance and Economy (in Russian). 
Gosudarstvennyi Sovet Rossiiskoi Federatsii (2015) Doklad o merakh po razvitiyu malogo i srednego predprinimatel'stva v Rossiiskoi Federatsii [Report on the Measures of Small and Medium Sized Enterprises Development in the Russian Federation], Moscow: Kremlin. Available at: http://www.smeforum.ru/upload/ iblock/f81/f810c5d73204a810a2889cfc43d6aae9.pdf, accessed 25.01.2016 (in Russian).

Granovetter M. (1985) Economic Action and Social Structure: The Problem of Embeddedness. The American Journal of Sociology, vol. 91, no 3, pp. 481-510.

Haus I., Steinmetz H., Isidor R., Kabst R. (2013) Gender Effects on Entrepreneurial Intention: A Meta-Analytical Structural Equation Model. International Journal of Gender and Entrepreneurship, vol. 5, no 2, pp. 130-156.

Heuer A., Liñán F. (2013) Testing Alternative Measures of Subjective Norms in Entrepreneurial Intention Models. International Journal of Entrepreneurship and Small Business, vol. 19, no 1, pp. 35-50.

Hughes M., Ireland R.D., Morgan R.E. (2007) Stimulating Dynamic Value: Social Capital and Business Incubation as a Pathway to Competitive Success. Long Range Planning, vol. 40, no 2, pp. 154-177.

Ivashchenko N.P., Engovatova A.A., Korostyleva I.I. (2014) Transformatsiya otechestvennykh vuzov v predprinimatel'skie: logika puti [Transformation of Domestic Universities into Entrepreneurial Ones: Logic of the Route]. Ekonomicheskie strategii, vol. 16, no 8 (124), pp. 130-135 (in Russian).

Karpunina M.A., Savinova S.Yu., Shubnyakova N.G. (2014) Formirovanie molodezhnogo predprinimatel'skogo soobshchestva kak instrument povysheniya predprinimatel'skoi aktivnosti v Possii [Formation of Youth Entrepreneurial Community as an Instrument for Development of Entrepreneurial Activity in Russia]. Sovremennye problemy nauki i obrazovaniya (electronic journal), vol. 2. Available at: http://science-education.ru/ $\mathrm{ru} /$ article/view?id=12360, accessed 15.02.2016 (in Russian).

Kautonen T., van Gelderen M., Fink M. (2015). Robustness of the Theory of Planned Behavior in Predicting Entrepreneurial Intentions and Actions. Entrepreneurship: Theory and Practice, vol. 39, no 3, pp. 655-674.

Kautonen T., van Gelderen M., Tornikoski E.T. (2013) Predicting Entrepreneurial Behavior: A Test of the Theory of Planned Behavior. Applied Economics, vol. 45, no 6, pp. 697-707.

Khairetdinova O.A. (2014) Znachenie studencheskogo predprinimatel'stva na sovremennom etape razvitiya Rossii [Importance of Student Entrepreneurship at the Contemporary Stage of Russia's Development]. Science Time, no 5 (5), pp. 225-233 (in Russian).

Kibler E. (2013) Formation of Entrepreneurial Intentions in a Regional Context. Entrepreneurship and Regional Development: An International Journal, vol. 25, no 3-4, pp. 292-323.

Klofsten M. (2000) Training Entrepreneurship at Universities: A Swedish Case. Journal of European Industrial Training, vol. 24, no 6, pp. 337-344.

Kolverei L., Moen O. (1997) Entrepreneurship among Business Graduates: Does a Major in Entrepreneurship Make a Difference? Journal of European Industrial Training, vol. 21, no 4/5, pp. 154-160.

Konstantinov G.N., Filonovich S.R. (2007) Chto takoe predprinimatel'skii universitet [What is a business-oriented university?], Voprosy obrazovania / Educational Studies Moscow, no 1, pp. 49-62 (in Russian).

Konyukhova E. (2014) Predprinimatel'skie kompetentsii kak garantii kachestva programm po obucheniyu predprinimatel'stvu [Entrepreneurial Competences as a Guarantee of the Entrepreneurial Education Quality]. Kachestvo obrazovaniya, no 12, pp. 48-52 (in Russian).

Krueger N.F. (2009) Entrepreneurial Intentions are Dead: Long Live Entrepreneurial Intentions. Understanding the entrepreneurial mind, international studies in entrepreneurship (eds. A.L. Carsrud, M. Brännback), New York: Springer, pp. 51-72.

Kutsenko E. (2015) Pilotnye innovatsionnye territorial'nye klastery Rossii: model' ustoichivogo razvitiya [Pilot Innovative Regional Clusters in Russia: Model for a Sustainable Development], Foresight and STI Governance, vol. 9, no 1, pp. 32-55 (in Russian).

Laspita S., Breugst N., Heblich S., Patzelt H. (2012) Intergenerational Transmission of Entrepreneurial Intentions. Journal of Business Venturing, vol. 27, no 4, pp. 414-435.

Lentz B.F., Laband D.N. (1990) Entrepreneurial Success and Occupational Inheritance among Proprietors. Canadian Journal of Economics, vol. 23, no 3, pp. 563-579.

Lévesque M., Minniti M. (2011) Age Matters: How Demographics Influence Aggregate Entrepreneurship. Strategic Entrepreneurship Journal, vol. 5, no 3, pp. 269-284.

Liñán F. Fayolle A. (2015) A Systematic Literature Review on Entrepreneurial Intentions: Citation, Thematic Analyses, and Research Agenda. International Entrepreneurship and Management Journal, vol. 11, no 4, pp. 907-933.

Liñán F., Chen Y.W. (2009) Development and Cross-Cultural Application of a Specific Instrument to Measure Entrepreneurial Intentions. Entrepreneurship: Theory \& Practice, vol. 33, no 3, pp. 593-617.

Liñán F., Rodriguez-Cohard J.C. (2015) Assessing the Stability of Graduates' Entrepreneurial Intention and Exploring its Predictive Capacity. Academia Revista Latinoamericana de Administración, vol. 8, no 1, pp. 77-98.

Makarov S., Ugnich E. (2015) Biznes-katalizatory kak draivery razvitiya regional'nykh innovatsionnykh sistem [Business Catalyzers as Drivers of Regional Innovation Systems Developmet]. Foresight-Russia, vol. 9, no 1, pp. 56-67 (in Russian).

McCarthy D., Puffer S., Darda S. V. (2010) Convergence in Entrepreneurial Leadership Style: Evidence from Russia. California Management Review, vol. 52, no 4, pp. 48-72.

Morales-Gualdron S.T., Roig S. (2005) The New Venture Decision: An Analysis Based on the GEM Project Database. International Entrepreneurship and Management Journal, vol. 1, no 4, pp. 479-499.

MSP Bank (2014) Index kachestva uslovii dlya malogo I srednego biznesa v 2012-2013 gg.: regional'nye disproportsii [Quality Index for SMEs in 2012-2013], Moscow: MSP Bank Analytical Center. Available at: https://www.mspbank. ru/userfiles/files/researches/index_kach_2012-2013_reg.pdf, accessed 21.04.2017 (in Russian).

Mueller P. (2006) Entrepreneurship in the Region: Breeding Ground for Nascent Entrepreneurs? Small Business Economics, vol. 27, no 1, pp. 41-58.

Nielsen S.L., Lassen A.H. (2012) Identity in Entrepreneurship Effectuation Theory: A Supplementary Framework. International Entrepreneurship and Management Journal, vol. 8, no 3, pp. 373-389.

Orbell S., Sheeran P. (1998) Inclined Abstainers': A Problem for Predicting Health-Related Behavior. British Journal of Social Psychology, vol. 37, no 2, pp. 151-165.

Parker S.C., Belghitar Y. (2006) What Happens to Nascent Entrepreneurs? An Econometric Analysis of the PSED. Small Business Economics, vol. 27, no 1, pp. 81-101.

Pavlov K.V. (2008) Regional'nye osobennosti razvitiya rossiiskogo predprinimatel'stva [Regional Peculiarities of Russian Entrepreneurship Development], Vestnik MGTU, vol. 11, no 2, pp. 254-263 (in Russian).

Peng M. (2003) Institutional Transitions and Strategic Choices. Academy of Management Review, vol. 28, no 1, pp. 275-296.

Puffer S.M., McCarthy D.J. (2001) Navigating the Hostile Maze: A Framework for Russian Entrepreneurship. Academy of Management Executive, vol. 15, no 3, pp. 24-36. 
Rauch A. (2014). Predictions of Entrepreneurial Behavior: A Personality Approach. Handbook of Research on Small Business and Entrepreneurship (eds. E. Chell, M. Karataş-Özkan), Cheltenham: Edward Elgar, pp. 165-183.

Reznik G.A., Ponomarenko Y.S. (2010) Studencheskoe predprinimatel'stvo kak vazhnyi faktor formirovaniya innovatsionnoi ekonomiki [Student Entrepreneurship as an Important Factor of Innovative Economy Formation]. Universitetskoe upravlenie: praktika i analiz, no 2, pp. 62-67 (in Russian).

Romanovskaya A. (2015) Bol'shie problemy malogo biznesa [Big Problems of Small Business]. Valovyi vnutrennii produkt (electronic journal), no 5(94). Available at: http://www.vvprf.ru/archive/clause1107.html, accessed 27.01.2016 (in Russian)

Saidullaev F.S. (2015) Dinamika razvitiya malogo predprinimatel'stva v regionakh Rossii v 2014 godu. Ezhekvartal'nyi informatsionno-analiticheskii otchet [Dynamics of Small-scale Entrepreneurship development in Russian Regions in 2014. Quarterly Analytical Report], Moscow: Natsional'nyi institut sistemnykh issledovanii problem predprinimatel'stva [National Institute for Entrepreneurship Research]. Available at: http://nisse.ru/upload/ iblock/01e/4\%20kvartal_2014.pdf, accessed 28.01.2016 (in Russian).

Schlaegel C., Koenig M. (2014) Determinants of Entrepreneurial Intent: A Meta Analytic Test and Integration of Competing Models. Entrepreneurship: Theory and Practice, vol. 38, no 2, pp. 291-332.

Sequeira S., Mueller S., McGee J. (2007) The Influence of Social Ties and Self-Efficacy In Forming Entrepreneurial Intentions and Motivating Nascent Behavior. Journal of Developmental Entrepreneurship, vol. 12, no 3, pp. 275-293.

Shapero A., Sokol L. (1982) Social dimensions of entrepreneurship. The Encyclopedia of Entrepreneurship (eds. C. Kent, D. Sexton, K. Vesper), Englewood Cliffs, NJ: Prentice-Hall, pp. 72-90.

Shchegolev V.V., Nikolaev N.A. (2014) Izuchenie i podderzhka predprinimatel'skikh namerenii studentov [Studying and Supporting Students' Entrepreneurial Intentions]. Sovremennye problemy nauki i obrazovaniya [Modern problems of science and education] (electronic journal), no 6. Available at: http://science-education.ru/ru/article/ view?id=16745, accessed 21.04.2016 (in Russian).

Shcherbakova E.A. (2012) Innovatsionnyi podkhod k obucheniyu predprinimatel'stvu [Innovative Approach towards Entrepreneurship Education]. Vestnik Yuzhno-Rossiiskogo gosudarstvennogo tekhnicheskogo universiteta (Novocherkasskogo politekhnicheskogo instituta). Seriya: Sotsialno-ekonomicheskie nauki, no 3, pp. 83-86 (in Russian).

Sheeran P. (2002) Intentions-Behavior Relations: A Conceptual and Empirical Review. European Review of Social Psychology, vol. 12, pp. 1-36.

Shirokova G., Osiyevskyy O., Bogatyreva K. (2016) Exploring the Intention-Behavior Link in Student Entrepreneurship: Moderating Effects of Individual and Environmental Characteristics. European Management Journal, vol. 34, no 4, pp. 386-399.

Shirokova G., Tsukanova T., Bogatyreva K. (2015a) Faktory formirovaniya predprinimatel'skikh namerenii rossiiskikh studentov [Antecedents of students's entrepreneurial intentions in Russia]. Vestnik Sankt-Peterburgskogo universitetata. Seriya Menedzhment [Vestnik of Saint Petersburg University. Management Series], no 3, pp. 21-46 (in Russian).

Shirokova G., Tsukanova T., Bogatyreva K. (2015b) Universitetskaya sreda i predprinimatel'skaya aktivnost' studentov: rol' biznes-opyta i predprinimatel'skoi samoeffektivnosti [University Environment and Student Entrepreneurship: The Role of Business Experience and Entrepreneurial Self-Efficacy]. Voprosy obrazovania / Educational Studies Moscow, no 3, pp. 171-207 (in Russian).

Shirokova G.V., Bogatyreva K.A., Galkina T.A. (2014) Effektuatsiya i kauzatsiya: vzaimosvyaz' mezhdu universitetskoi infrastrukturoi $\mathrm{i}$ vyborom tipa povedeniya $\mathrm{v}$ protsesse sozdaniya biznesa studentami-predprinimatelyami [Effectuation and Causation: Relationship Between University Infrastructure and Behavioral Choice in New Venture Creation by Student-Entrepreneurs], Rossiiskii zhurnal menedzhmenta [Russian Management Journal], vol. 12, no 3, pp. 59-86 (in Russian).

Shook C.L., Bratianu C. (2010) Entrepreneurial Intent in a Transitional Economy: An Application of the Theory of Planned Behavior to Romanian Students. International Entrepreneurship and Management Journal, vol. 6, no 3, pp. 231-247.

Sniehotta F.F., Schwarzer R., Scholz U., Schüz B. (2005) Action Planning and Coping Planning for Long-Term Lifestyle Change: Theory and Assessment. European Journal of Social Psychology, vol. 35, vol. 4, pp. 565-576.

Stenholm P., Acs Z.J., Wuebker R. (2013) Exploring Country-Level Institutional Arrangements on the Rate and Type of Entrepreneurial Activity. Journal Business Venturing, vol. 28, no 1, pp. 176-193.

Sutton S. (1998) Predicting and Explaining Intentions and Behavior: How Well are We Doing? Journal of Applied Social Psychology, vol. 28, no 15, pp. 1317-1338.

Tappaskhanova E.O., Batova B.Z., Zumakulova Z.A. (2014) Realizatsiya kontseptsii «predprinimatel'skogo universiteta» v regione: Ekonomiko-pravovoi aspekt [Realization of the "Entrepreneurial University" Concept in the Region: Economics and Law Perspective]. Ekonomika i predprinimatel'stvo [Journal of Economy and Entrepreneurship], no 4-2 (45-2), pp. 949-952 (in Russian).

Transparency International (2015) Corruption Perceptions Index 2015. Available at: https://www.transparency.org/ cpi2015, accessed 29.01.2016.

Van Gelderen M., Kautonen T., Fink M. (2015) From Entrepreneurial Intentions to Actions: Self-Control and ActionRelated Doubt, Fear, and Aversion. Journal of Business Venturing, vol. 30, no 5, pp. 655-673.

World Bank (2015) Doklad ob ekonomike Rossii [Russia Economic Report] (World Bank Report no 33). Available at: http://www.worldbank.org/content/dam/Worldbank/document/eca/russia/rer33-rus.pdf, accessed 25.01.2016 (in Russian).

Welter F. (2011) Contextualizing Entrepreneurship - Conceptual Challenges and Ways Forward. Entrepreneurship Theory and Practice, vol. 35, no 1, pp. 65-184.

Welter F., Smallbone D. (2011) Institutional Perspectives on Entrepreneurial Behavior in Challenging Environments. Journal of Small Business Management, vol. 49, no 1, pp. 107-125.

Zakharova A.A. (2013) Problemy razvitiya predprinimatel'skoi aktivnosti studentov v sovremennykh usloviyakh [Current Issues of Student Entrepreneurial Activity Development]. Innovatsii v sovremennoi nauke. Materialy II Mezhdunarodnogo osennego simpoziuma [Innovations in Contemporary Science. Materials of the $2^{\text {nd }}$ International Autumn Simposium] (ed. G.F. Grebenshchikov), Moscow, pp. 139-142 (in Russian).

Zanakis S.H., Renko M., Bullough A. (2012) Nascent Entrepreneurs and the Transition to Entrepreneurship: Why Do People Start New Businesses? Journal of Developmental Entrepreneurship, vol. 17, no 1, pp. 1-25.

Zhang Y., Duysters G., Cloodt M. (2014) The Role of Entrepreneurship Education as a Predictor of University Students' Entrepreneurial Intention. International Entrepreneurship and Management Journal, vol. 10, no 3, pp. 623-641.

Zhao H., Seibert S., Hills G. (2005) The Mediating Role of Self-Efficacy in the Development of Entrepreneurial Intentions. Journal of Applied Psychology, vol. 90, no 6, pp. 1265-1272. 


\title{
The Automation of Jobs: A Threat for Employment or a Source of New Entrepreneurial Opportunities?
}

\author{
Alina Sorgner ${ }^{a ; b}$ \\ Researcher, alina.sorgner@uni-jena.de \\ a School of Economics and Business Administration, Friedrich Schiller University Jena, \\ Carl-Zeiss-Str. 3, 07743 Jena, Germany. \\ ${ }^{\mathrm{b}}$ Kiel Institute for the World Economy, Kiellinie 66 D-24105 Kiel, Germany.
}

\begin{abstract}
$\mathrm{N}$ ew and emerging technologies pose a serious challenge for the future of employment. As machines learn to accomplish increasingly complex production tasks, the concern arises that automation will wipe out a great number of jobs. This paper investigates the relationship between the risk posed by the automation of jobs and individual-level occupational mobility using a representative German household survey. It provides an overview of current trends and developments on the labor markets due to the automation of jobs. It also describes the most recent dynamics of self-employment and relates it to the risk of the automation of jobs.

The results suggest that the expected occupational changes such as losing a job, demotion at one's current place of employment, or starting a job in a new field are

likely to be driven by the high occupation-specific risk of automation. However, the switch to self-employment, both with and without employees, is more likely to occur from paid employment in occupations with a low risk of automation. Hence, the rising level of entrepreneurial activities is less likely due to jobs becoming obsolete over the course of automation, but rather due to the high number of opportunities offered by the digital age.

The issues addressed within the paper provide room for further investigation. Particularly, an important question concerns which additional skills workers in jobs with a high risk of automation should acquire in order to make themselves less susceptible to the negative consequences of such a change. More research is needed in order to develop educational strategies to make workers less susceptible to job loss due to automation.
\end{abstract}

\section{Keywords:}

automation;

jobs;

occupational mobility;

entrepreneurship;

digitalization.

Citation: Sorgner A. (2017) The Automation of Jobs:

A Threat for Employment or a Source of New

Entrepreneurial Opportunities? Foresight and STI

Governance, vol. 11, no 3, pp. 37-48. DOI: 10.17323/2500-

2597.2017.3.37.48 
$\mathrm{R}$ ecent technological progress, particularly in the field of ICT, has led to the emergence of Industry 4.0, the fourth industrial revolution, and has given rise to a debate about the future of employment There is great concern that as technology develops further, it will become possible for machines to perform tasks at least as efficiently as the humans who are currently performing them. As a consequence, it is feared that automation will lead to a massive wipe-out of jobs. Researchers from the University of Oxford, Carl Benedikt Frey and Michael Osborne, recently arrived at the conclusion that, given the current state of technology, about 47 percent of the US labor force are in jobs that are highly likely to be replaced by machines in the next 10-20 years [Frey, Osborne, 2013, 2017]. Numerous follow-up studies generally confirmed this scenario for other countries, though they report great variations in automation risk across countries. ${ }^{1}$

The aforementioned studies, however, provide estimates based on aggregate employment data and it therefore remains unclear whether or not and how far the predicted risk of job automation ${ }^{2}$ is associated with occupational mobility at the individual level. Hence, the present paper aims to shedd more light on this relationship by investigating whether working in an occupation with a high risk of automation affects job changes, such as the risk of losing one's job, demotion at one's current place of employment, or starting a job in a new field, among others. Then, this paper investigates the impact of the automation of jobs on the probability of becoming an entrepreneur. The recent rise of entrepreneurship in many developed countries that has been observed over the last two decades raises many questions with regard to the drivers of this development and the quality of those start-ups. Particularly, the technological progress that leads to the automation of jobs may foster start-ups created by necessity by those people whose jobs are likely to be replaced with machines. At the same time, technological progress may lead to an increase in the level of opportunity-driven and growth-oriented start-ups. For instance, Shane [Shane, 2000] discusses how the introduction of a radical innovation such as $3 \mathrm{D}$ printing technology has led to the emergence of entrepreneurial opportunities in very different fields ranging from the creation of personalized sculptures from a photo to constructing prototype models of industrial and architectural design to printing out artificial bones and creating three-dimensional human brain models for surgical planning. Obviously, some of those opportunities emerge in fields (e.g., surgery) in which machines complement rather than substitute human labor.

The present empirical analysis is based on German Socio-Economic Panel data, an annual representative survey of German households containing rich information on an individual's socioeconomic background. The results suggest that the risk of the automation of jobs increases the risk of occupational changes such as losing a job, demotion at one's current place of employment, or starting a job in a new field within the next two years. At the same time, the risk of automation is negatively correlated with the probability of becoming an entrepreneur, both with and without employees. This suggests that entrepreneurs are less likely to be driven by necessity arising from the risk of job automation. Thus, the rising level of entrepreneurship in Germany is more likely to be driven by new technology creating new entrepreneurial opportunities rather than by destroying jobs.

\section{The Labor Market in the Digital Age: Trends and Developments}

This section reviews trends and developments that are currently present on the labor markets of many developed countries and are related to the current progress in the automation of tasks. In particular, we describe the phenomenon of the polarization of labor markets. Then, we discuss the consequences of automation for the future of employment by considering current trends in the rate of entrepreneurial activities.

\section{Which jobs are at risk of automation?}

In order to understand which jobs are at high risk of automation, it is necessary to analyze what types of tasks can be effectively and efficiently performed by computers and those tasks in which computers merely supplement human labor. The authors of [Autor et al., 2003] distinguish between two broad sets of tasks according to the extent of their vulnerability to computerization, namely, routine and non-routine tasks. The group of non-routine tasks can be further divided into manual and abstract tasks. Due to the nature of routine tasks that may be both cognitive (e.g. performing calculations) and physical (e.g., repetitive operations in a stable environment), they can be fully codified and thus jobs that mainly comprise routine tasks are highly susceptible to computerization. While machines outperform humans in many of the routine tasks, they have not yet achieved high performance levels when carrying out non-routine tasks, that is, manual and abstract tasks. Manual tasks are those activities that can be easily performed by humans but require enormous computing power from machines. Examples of such tasks are manual operations in unstable, changing environments that require high adaptability and manual dexterity as well as visual and language recognition. One should note, however, that the current progress in artificial intelligence (AI) is

\footnotetext{
${ }^{1}$ See, e.g., [Arntz et al., 2016], for an analysis of OECD countries; [Sorgner et al., 2017a] for G20 countries; [Chang, Huynh, 2016], for ASEAN countries; [Dengler, Matthes, 2015], for the case of Germany; [Pajarinen et al., 2015], for an analysis of Finland and Norway).

${ }^{2}$ In this paper the terms computerization, digitization, and automation are used interchangeably.
} 
quite impressive and it can be expected that machines will learn to perform those tasks even better in the near future (see [Brynjolfsson, McAfee, 2014], for other examples). Still, humans currently perform these tasks at a much lower cost, which is why there is a relatively low risk of computerization for such jobs. Last but not least, abstract tasks require creativity, persuasion, and problem-solving skills, in such capacities computers tend to complement highly educated workers.

Given this state of technology, the major trend that is currently observed in various developed countries is that of the polarization of labor markets [Autor, 2015a; Autor, Dorn, 2013; Goos et al., 2014]. Job polarization is a phenomenon that refers to the growth of employment at opposite ends of the occupational skill spectrum. That is, there has been an increase in highly paid jobs that require high levels of education and are mostly comprised of abstract tasks on the one hand, and on the other, there is growth in low-pay jobs that comprise manual tasks performed by people with lower levels of education.

Recently, in a study of the future of employment in the US, Frey and Osborne [Frey, Osborne, 2013, 2017] arrived at the conclusion that about 47 percent of the US labor force is currently working in occupations with a particularly high risk of being computerized in the next 10-20 years. Those high-risk occupations mainly comprise transportation and logistics occupations, office and administrative support workers, and production occupations. The OECD's Directorate for Employment, Labour and Social Affairs commissioned a similar study for OECD countries [Arntz et al., 2016], whose authors concluded that the risk of automation might have been overestimated. On contrary, they find that, on average across the 21 OECD countries, only about $9 \%$ of jobs are automatable, although there is great variation between the countries. The highest risk of automation was found for Germany and Austria (12\%) and the lowest for Korea and Estonia (6\%). The study by Chang and Huynh [Chang, Huynh, 2016] of ASEAN countries, however, reports that about 56 percent of employment is at high risk of displacement over the next decade or two. And the study by Sorgner, Bode, and Krieger-Boden [Sorgner et al., 2017a] of G20 countries provides evidence of gender-specific differences in the effects of automation on employment, which also vary strongly across countries. This strong crosscountry variation may reflect general differences in the industrial structures of the economies in those countries. For instance, knowledge-intensive sectors have jobs that heavily rely upon abstract tasks, while many jobs in manufacturing sectors are routine-based and, thus, susceptible to automation.

While the study by Frey and Osborne [Frey, Osborne, 2013, 2017] for the US and similar studies for other countries focused on aggregated employment data, it is not clear how the risk of automation and computerization affects occupational changes at the level of individuals, such as transitions from paid employment into unemployment or self-employment. Hence, this paper's aim is to shed more light on this issue by investigating micro-level data.

\section{The automation of jobs and the rise of entrepreneurship}

A pronounced development that many developed countries are currently experiencing is that of a fundamental shift from a managed economy to an entrepreneurial economy. The term 'managed economy' refers to the organization of market economies after WWII that were characterized by the prevalence of economies of scale, standard production routines, high levels of specialization and relatively low levels of uncertainty in the manufacturing process. In contrast to the managed economy, the entrepreneurial economy is predominantly based on pronounced start-up activity, innovation that occurs at entrepreneurial organizations, flexible production and flexible labor markets, and relatively high levels of uncertainty [Audretsch, Thurik, 2000, 2001]. Moreover, new business formation, while being largely neglected by policy makers in the managed economies - starts to play an increasingly important role in the entrepreneurial economy with regard to its direct effects such as job creation [Acs, 2011] and, more importantly, the indirect effects. Concerning the latter, start-ups represent an important challenge for incumbent firms and, thus, force them to perform more efficiently [Fritsch, 2011]. Last but not least, new entrants may create new markets by introducing radical innovations [Baumol, 2004].

This shift towards a more entrepreneurial economy is well reflected in Figure 1, which shows the dynamics of self-employment rates in Germany during the period between 1991 and 2012. The self-employment rate grew steadily from about 8 percent in the beginning of the observation period up to about 11.5 percent at the end of the period. It is worth noting that this development cannot be entirely attributed to the former GDR's transition to a market economy, although the event of German reunification contributed significantly to the rise of the overall self-employment rate in Germany. Particularly, the self-employment rate in East Germany converged with the level of self-employment activities in West Germany around 2004 and even exceeded it thereafter. Nevertheless, the rise of entrepreneurial activities can also be observed in West German regions. This evidence leads to a question of what the drivers of this fundamental move towards a more entrepreneurial society are. The rising level of entrepreneurial activities may simply reflect various structural changes in a society. For instance, changes in the socio-demographic characteristics of the population, such as the age structure, the increased rate of female participation in the labor market, and an average higher level of education, might have led to a rise in entrepreneurship [Fritsch et al., 2015]. ${ }^{3}$ Moreover, the incentives

${ }^{3}$ This is because socio-demographic characteristics are important determinants for making the decision to become an entrepreneur [Parker, 2009]. 


\section{Figure 1. Dynamics of self-employment rates in Germany, 1991-2012}

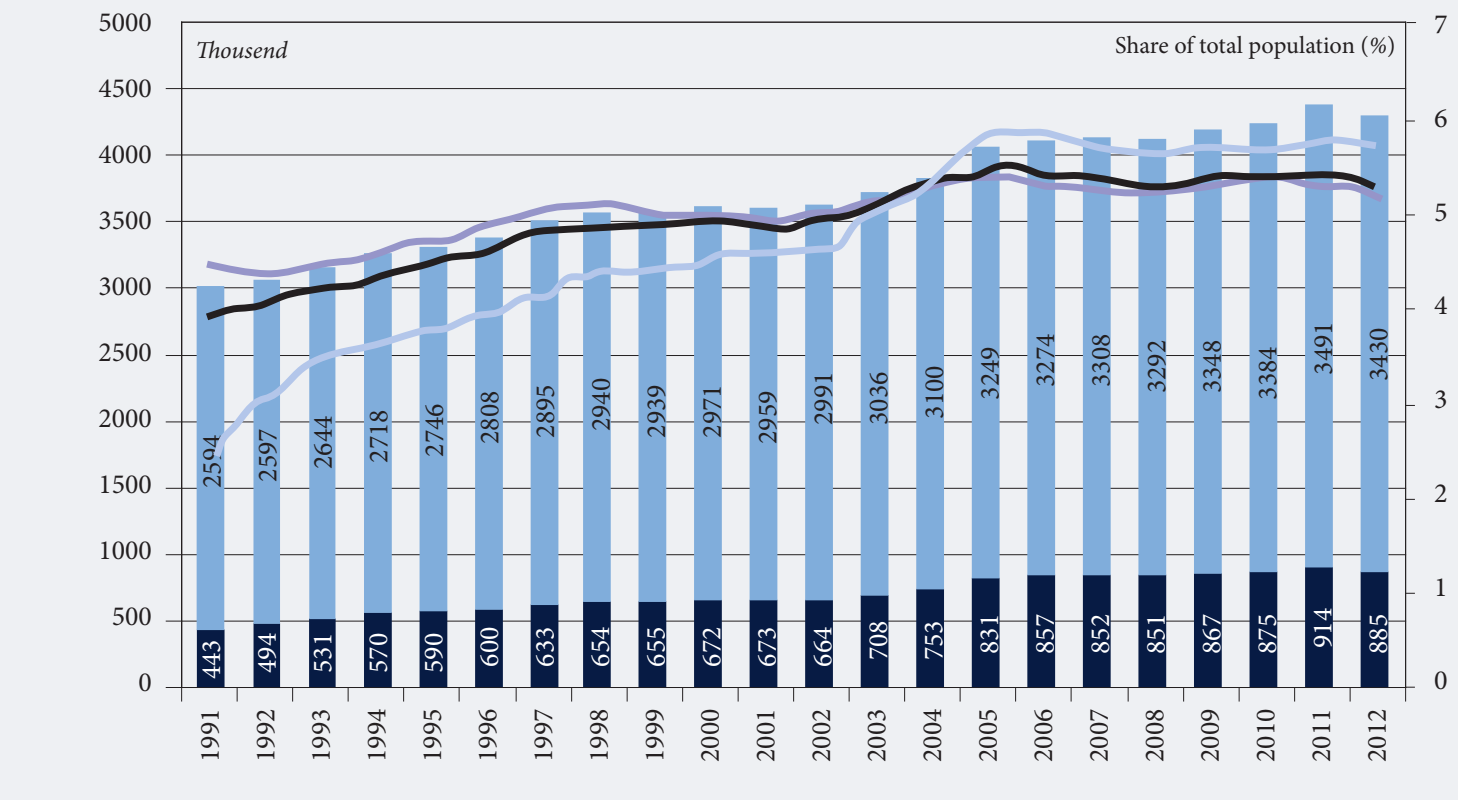

East Germany (including Berlin)

West Germany

Self-employment rate in Germany

Self-employment rate in West Germany

Self-employment rate in East Germany

Source: own calculations based on the German Micro-Census.

to become an entrepreneur may have changed as a response to a variety of policy measures designed to promote entrepreneurship that have been realized over approximately the last two decades. For example, in Germany, a whole range of public policy measures have been realized, which promoted, for instance, start-ups by unemployed persons [Caliendo, Kritikos, 2010] and by students as well as highly educated staff at universities and other public research institutes ('EXIST'). Some of those programs aim to reduce start-up barriers for women related to human and financial capital for women [Welter, 2006]. Those policy measures may have at least partially shaped a more pro-entrepreneurial attitude among the population and a stronger awareness of entrepreneurship as an alternative career option thus contributing to the growth of entrepreneurship. Last but not least, technological progress, in particular achievements in ICT that gave rise to the fourth industrial revolution, may be responsible for a great number of entrepreneurial opportunities and the shift towards an entrepreneurial economy in many developed countries [Audretsch, Thurik, 2000].

Remarkably, Figure 2 demonstrates that the rise of self-employment rates in Germany was predominantly due to the rise in self-employment without employees (solo self-employment). While the solo selfemployment rate increased from about 3.5 percent in 1991 to 6 percent in 2012, the level of self-employment with employees increased only negligibly. The businesses of the solo self-employed have often been regarded as secondary (low quality) start-ups, as they generally do not create much value in terms of innovation, employment growth, and wealth generation [Shane, 2009].

This recent rise in the level of self-employment is quite remarkable and requires investigation, as there is not much evidence concerning the reasons behind this development and about the quality of such startups. Fritsch et al. [Fritsch et al., 2015] conducted a decomposition analysis of self-employment rates in Germany over time in order to determine the major drivers of such a pronounced, radical change. They provide evidence that demographic developments, such as the shift towards employment in the service sector and a larger share of the population holding tertiary degrees, are the major drivers of the increase in the overall level of self-employment. While these factors explain most of the developments in selfemployment with employees, they could only explain less than a half of the much more dramatic increase in self-employment without employees. In particular, it remains unclear whether or not and how far the rise of solo self-employment was triggered by technological progress that has led to the automation of jobs. It can be assumed that people in jobs with a relatively high risk of automation may be more likely to set up businesses out of necessity. Furthermore, it can be expected that such businesses are less likely to be growth-oriented, as they have been created with the primary aim of employing the business owner

\footnotetext{
${ }^{4}$ Other policy measures include, for instance, the deregulation of a number of liberal occupations, the introduction of minimum capital requirements for setting up a limited liability company, changes to personal bankruptcy law, and more restricted access to social security support.
} 


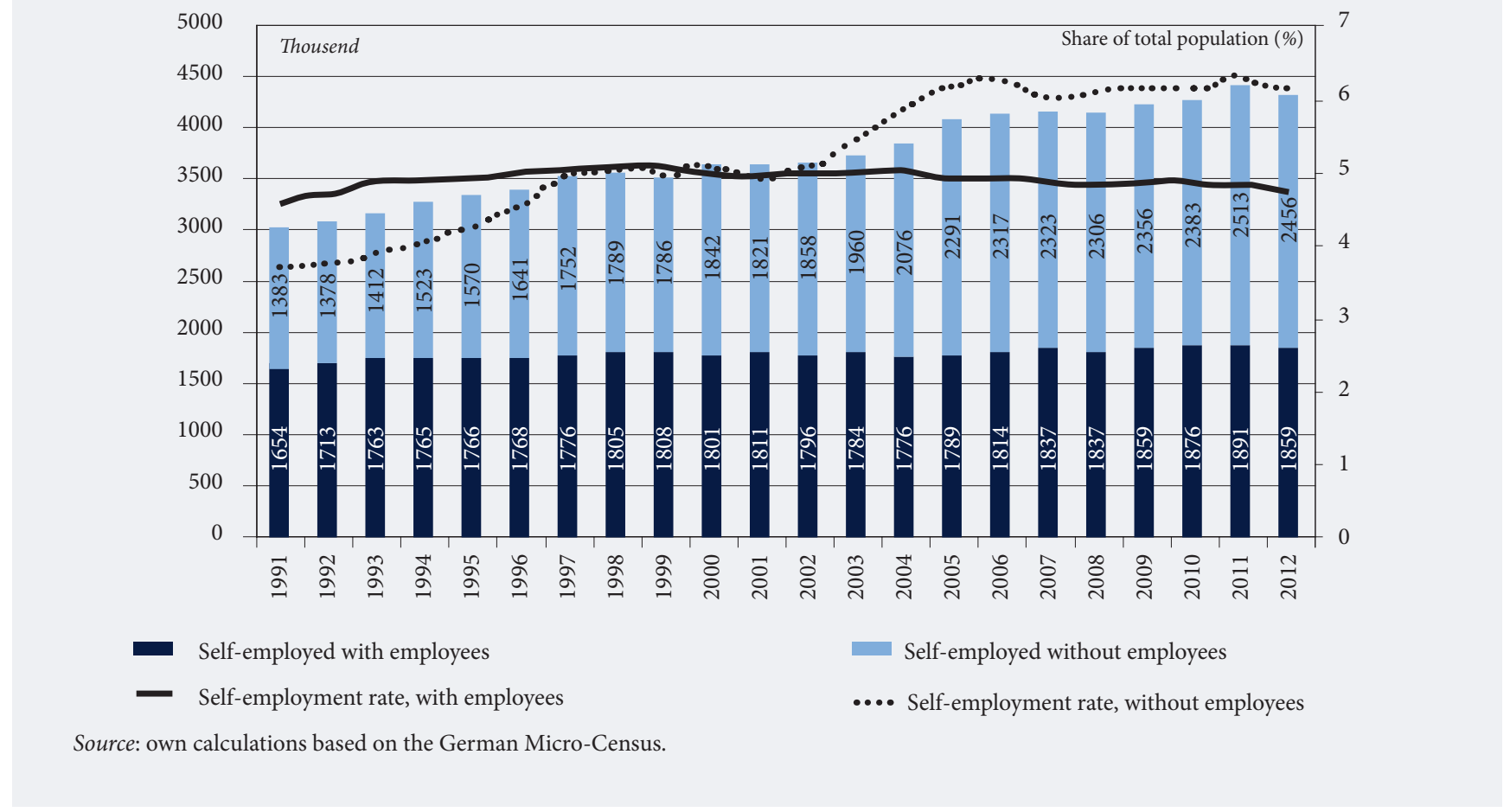

[Shane, 2009]. Thus, the automation of human labor may indeed drive the levels of solo self-employment "out of necessity". On the contrary, technological progress may lead to a rise in opportunity-driven, growthoriented entrepreneurship in fields that are less susceptible to automation and are characterized by creative and abstract tasks. Hence, another aim of this paper is to investigate the relationship between the risk of job automation and an individual's likelihood of becoming an entrepreneur.

\section{Data and method}

\section{Data source}

The empirical analysis is based on German Socio-Economic Panel (SOEP) data, which is an annual representative household survey conducted by the German Institute for Economic Research (DIW). It includes detailed information about the socioeconomic situations of approximately 22,000 individuals living in Germany [Wagner et al., 2007]. For the purposes of the present analysis, data for the time period from 2005 to 2013 was used.

\section{Dependent variables}

Currently employed individuals are asked in the SOEP to assess the probability of occupational changes over the next two years on a 10-point Likert scale from 0 to 100 with 10 -point steps. The questions comprise various types of occupational changes related to losing or switching a job, an occupational promotion or demotion, expected wage/salary increases, etc. Many of those changes might occur as a consequence of the progress of computerization and/or the automation of jobs. The precise wording of questions used in the present study is as follows:

"How likely is it that you will experience the following career changes within the next two years? Please estimate the probability on a scale of 0 to 100 , with 0 meaning that such a change definitely will not take place, and 100 meaning that such a change definitely will take place."

- "Will you lose your job?"

- "Will you stop working in your current field and start working in a different one?"

- "Will you be demoted at your current place of employment?"

- "Will you attend courses or seminars to obtain additional training or qualifications?"

- "Will you receive a salary or wage increase beyond the collectively negotiated wage increases?"

- "Will you start working on a self-employed and/or freelance basis?"

In addition to the anticipated occupational changes, in our further analysis we study the actual transitions from paid employment to unemployment and self-employment. To this end, two dependent variables were constructed as binary variables that equal to one if a respondent's observed employment status in time period $t$ is paid employment and his or her employment status two years later is unemployment (self- 
employment). In addition, for respondents who switched from paid employment to self-employment, we distinguish between those who did so on a solo basis and those who are self-employed with employees, in order to partially account for necessity- and opportunity-based motives. ${ }^{5}$

\section{Independent variable}

The variable of interest is the occupation-specific probability of automation, which indicates the level of risk for a particular occupation to be automated or computerized in the next one to two decades. This variable is based upon and was adapted from the study by Frey and Osborne [Frey, Osborne, 2013, 2017], who estimated the automation/computerization probabilities for 702 occupations according to the US occupational classification system, $\mathrm{O}^{\star} \mathrm{Net}$. Together with a group of experts in machine learning and robotics, Frey and Osborne were able to identify a set of occupations that they labeled with 1, meaning a 100 percent probability of the occupation being computerized in the next one to two decades, or 0 if the risk of computerization was considered absent. ${ }^{6}$ In the next step, they identified technological bottlenecks for computerization, that is, occupation-specific tasks that represent a challenge for machines. In particular, they identified three types of such bottlenecks, namely, social intelligence, creativity, and manipulation (perception). While social intelligence and creativity require high abilities and represent abstract tasks, manipulation and perception are mostly manual tasks (such as manual dexterity or tasks that are related to an unstructured work environment) that can be easily performed by humans, but represent a significant challenge for robots and machines. ${ }^{7}$ Finally, on the basis of the labeled data set, the researchers developed the optimal predicting algorithm, which they then used to estimate the probabilities of computerization for the remaining occupations based on the extent to which they are composed of tasks that pose bottlenecks to computerization.

Frey and Osborne [Frey, Osborne, 2013, 2017] provide the estimated probabilities of computerization for the 6-digit U.S. System of Occupational Classification (2010 SOC). Hence, they need to be converted to the 4-digit ISCO88 occupations that are available in SOEP in order to match them with other individual-level information. For this purpose, the algorithm created by the US Bureau of Labor Statistics was used.

\section{Control variables}

A wide set of control variables is considered, which can affect an individual's occupational mobility. In particular, information is available about the number of years that a respondent spent in formal education, tenure with his or her current employer, experienced years of unemployment, socio-demographic characteristics including age, gender, nationality, and children in the household. Moreover, SOEP data include short item scales that measure the Big Five dimensions of the personality [Costa, McCrae, 1992]. In particular, the survey includes 15 items, three for each of the five traits, which has been shown to accurately replicate the results of the more extensive 25-item Big Five inventory [Gerlitz, Schupp, 2005]. Psychological personality characteristics may affect an individual's willingness to change occupations in general, for instance, if a person has strong preferences for variety in his or her occupational environment [Astebro, Thompson, 2011]. Another reason for including personality traits in the model is that they may, to a certain extent, capture unobserved abilities beyond those measured by the level of formal education that may affect both the choice of a certain occupation and the probability of occupational changes. For a definition of the variables used in the analysis and how certain traits were measured see Table 1, which provides information on the descriptive statistics for independent variables. According to this table, the average respondent in the sample is about 42 years old and has enjoyed about 12.2 years of formal education. The average respondent has been at his or her current job for about 11 years and has experienced 0.9 years of unemployment in the past.

\section{Method}

The regression method used in the empirical analysis of expected occupational changes accounts for the peculiarities of the dependent variable, which is the probability of an occupational change occurring within the next two years. Since the dependent variable is bounded between zero and one, the model can be estimated by means of a fractional response model (FRM) proposed by Papke and Wooldridge [Papke, Wooldridge, 1996].

The analysis of transitions from paid employment to unemployment and self-employment is conducted by means of a probit regression, which accounts for the binary nature of the dependent variable that takes a value of 1 if an occupational change has occurred and takes a value of 0 if this was not the case.

\footnotetext{
${ }^{5}$ It should be noted, however, that not all solo self-employed started their businesses out of necessity. For instance, Sorgner et al. [Sorgner et al., 2017b] show that while the solo self-employed tend to have lower incomes than comparable entrepreneurs with paid employees, there are entrepreneurial "super-stars" among the solo self-employed who earn more. The data do not allow for making a more precise distinction between the motives for a start-up.

${ }^{6}$ Examples of occupations that they labeled with 1 are legal assistants or fast food cooks. Examples of occupations with a 0 , no risk of computerization, are housekeepers, taxi drivers or economists.

${ }^{7}$ This phenomenon is also known as Polanyi's paradox, which refers to the inability to convert tacit knowledge into codifiable and, hence, computerizable rules [Autor, 2015b].
} 
Table 1. Descriptive statistics for independent variables

\begin{tabular}{|c|c|c|c|}
\hline Variable & Definition and measurement & Mean & $\begin{array}{r}\text { Standard } \\
\text { deviation }\end{array}$ \\
\hline $\begin{array}{l}\text { Occupation-specific } \\
\text { probability of automation }\end{array}$ & $\begin{array}{l}\text { The risk of a certain occupation being computerized in the next 10-20 years. } \\
\text { Adapted from [Frey, Osborne, 2013, 2017] }\end{array}$ & 0.471 & 0.313 \\
\hline Years of formal education & Number of years spent in formal education & 12.219 & 2.700 \\
\hline Tenure, years & Number of years spent at the current place of employment & 11.016 & 10.367 \\
\hline $\begin{array}{l}\text { Experience of unemployment, } \\
\text { years }\end{array}$ & Number of years spent in unemployment & 0.917 & 2.307 \\
\hline Age & Respondent's age & 41.971 & 22.368 \\
\hline Gender & Dummy variable indicating the gender of a respondent ( $=1$ if male, $=0$ if female) & 0.489 & 0.500 \\
\hline Nationality & $\begin{array}{l}\text { Dummy variable indicating the nationality of a respondent (=1 if German, }=0 \\
\text { otherwise) }\end{array}$ & 0.715 & 0.451 \\
\hline $\begin{array}{l}\text { Presence of children in the } \\
\text { household }\end{array}$ & $\begin{array}{l}\text { Dummy variable indicating if there are children in the household ( }=1 \text { if yes, }=0 \\
\text { if no) }\end{array}$ & 0.393 & 0.488 \\
\hline Willingness to take risks & $\begin{array}{l}\text { Likert-type scale from } 0 \text { ("completely unwilling to take risks" to } 10 \text { ("fully } \\
\text { willing to take risks") Precise question: "Are you generally a person who is fully } \\
\text { prepared to take risks or do you try to avoid taking risks?" }\end{array}$ & 4.564 & 2.329 \\
\hline Conscientiousness & $\begin{array}{l}\text { Average score from the scores on } 3 \text { questions (7-point Likert-type scale) } \\
\text { measuring the Big Five dimension "Conscientiousness" }\end{array}$ & 5.827 & 0.961 \\
\hline Extraversion & $\begin{array}{l}\text { Average score from the scores on } 3 \text { questions (7-point Likert-type scale) } \\
\text { measuring the Big Five dimension "Extraversion" }\end{array}$ & 4.818 & 1.140 \\
\hline Agreeableness & $\begin{array}{l}\text { Average score from the scores on } 3 \text { questions (7-point Likert-type scale) } \\
\text { measuring the Big Five dimension "Agreeableness" }\end{array}$ & 5.398 & 0.978 \\
\hline Openness to experience & $\begin{array}{l}\text { Average score from the scores on } 3 \text { questions (7-point Likert-type scale) } \\
\text { measuring the Big Five dimension "Openness to experience" }\end{array}$ & 4.485 & 1.212 \\
\hline $\begin{array}{l}\text { Neuroticism (reversed } \\
\text { emotional stability) }\end{array}$ & $\begin{array}{l}\text { Average score from the scores on } 3 \text { questions (7-point Likert-type scale) } \\
\text { measuring the Big Five dimension "Degree of emotional stability" (emotional } \\
\text { stability vs. neuroticism) }\end{array}$ & 3.865 & 1.228 \\
\hline Internal locus of control & $\begin{array}{l}\text { Average score on two 7-point Likert scales measuring the internal locus of } \\
\text { control. Precise statements: "How my life goes depends on me" and "One has to } \\
\text { work hard in order to succeed" }\end{array}$ & 5.737 & 0.954 \\
\hline External locus of control & $\begin{array}{l}\text { Average score on six 7-point Likert scales measuring external locus of control. } \\
\text { Precise questions: 1) What a person achieves in life is above all a question of fate } \\
\text { or luck; 2) Compared to other people, I have not achieved what I deserve; } \\
\text { 3) I frequently have the experience that other people have a controlling influence } \\
\text { over my life; 4) The opportunities that I have in life are determined by social } \\
\text { conditions; 5) Innate abilities are more important than any efforts that one can } \\
\text { make; 6) I have little control over the things that happen in my life. }\end{array}$ & 3.683 & 0.940 \\
\hline
\end{tabular}

\section{Descriptive results}

According to Table 2, the highest average probability of an occupational change to occur within the next two years reported by currently employed respondents was related to the risk being demoted at one's current place of employment (about 46 percent), followed by the probability of acquiring additional qualifications (about 39 percent) and losing a job (about 21 percent). Interestingly, the lowest average probability of occupational change is that due to a shift to self-employment (about 8 percent). Nevertheless, it should be noted that this number is about 8 times higher than the yearly start-up rate in Germany, which is only about 1 percent [Fritsch et al., 2012]. This indicates a rather high willingness among the German population to set up a business, a potential event that apparently could not be realized to its full extent. ${ }^{8}$

Table 3 presents the probability of occupational changes for respondents who are in occupations that are differently affected by the risk of automation. In particular, we distinguish between three groups of automation risk: low (less than 30 percent), medium (30 to 70 percent) and high (more than 70 percent). The descriptive evidence in Table 3 suggests that the probability of occupational changes increases with the rising risk of computerization for the categories of losing a job, starting work in a new field, and demotion at a current job. Moreover, a higher risk of the computerization of an occupation is associated with an on average lower probability of acquiring additional qualifications. The same pattern was observed for the probability of becoming self-employed. Last but not least, there seems to be a non-linear relationship between the risk of automation and the probability of an increase in wages. However, this relationship may be determined by other factors, such as previous labor market experience or the level of formal education,

\footnotetext{
${ }^{8}$ The reasons for this may be manifold, such as a lack of financial capital, the inability to identify a profitable entrepreneurial opportunity, or the decreasing level of over-optimism over the business's gestation period.
} 


\section{Table 2. Descriptive statistics for dependent variables (the probability of occupational changes} within the next 2 years)

\begin{tabular}{|l|c|c|}
\hline \multicolumn{1}{|c|}{ Questions on the probability of occupational changes } & Mean (\%) & $\begin{array}{c}\text { Standard } \\
\text { deviation }\end{array}$ \\
\hline Will you lose your job? & 20.79 & 25.58 \\
\hline Will you stop working in your current field and start working in a different one? & 12.17 & 23.34 \\
\hline Will you be demoted at your current place of employment? & 46.28 & 14.88 \\
\hline Will you attend courses or seminars to obtain additional training or qualifications? & 38.64 & 36.12 \\
\hline Will you receive a salary or wage increase beyond the collectively negotiated wage increases? & 15.80 & 25.64 \\
\hline Will you start working on a self-employed and/or freelance basis? & 7.94 & 20.44 \\
\hline Source: author's calculations. & \multicolumn{2}{|c}{} \\
\hline
\end{tabular}

among others. Hence, this relationship will be investigated in the next section in a multivariate analysis, in which we control for a wide set of socio-demographic characteristics that may influence the result.

\section{The Results of Multivariate Analysis \\ The risk of computerization and perceived occupational changes}

The results of a multivariate analysis of the relationship between the occupation-specific probability of computerization and the self-reported probability of occupational changes within the next two years are reported in Table 4. In order to test for a possible non-linear relationship, the occupation-specific probability of computerization enters the model together with its squared term. The results suggest that there is a statistically significant reversed U-shaped relationship between the risk of computerization and the self-reported probability of losing current paid employment (Column I) as well as the likelihood of giving up working in one's current occupational field and starting a job in a completely new occupation (Column II). This result is quite surprising because it means that the risk of occupational change increases with the rising risk of automation only to a certain threshold level. People in occupations with a very high risk of automation are less likely than people in occupations with a medium risk to expect occupational changes related to losing their job or starting a job in a completely new field within the next two years. One possible reason for this finding may be related to existing labor market regulations with regard to employees' protection against dismissal. ${ }^{9}$ Alternatively, employees in occupations with a high risk of automation may be over-optimistic about the future of their occupations and, thus, underestimate the risk of losing their jobs. Next, the labor market polarization implies that the highest risk of automation applies to middle-skill workers in routine jobs. Moreover, these workers will be prone to downward occupational mobility when they are displaced by machines, unless they possess or acquire skills that are not susceptible to computerization, such as creativity or social intelligence. Hence, it can be expected that the higher the risk of automation of jobs, the higher is the likelihood of being demoted at one's current place of employment. The results in Column IV of Table 4 support this hypothesis: there is a statistically significant (although at a $10 \%$ level) effect of occupational automation risk on the probability of demotion at one's current place of employment within the next two years. ${ }^{10}$

\section{Table 3. Probability of occupational changes in the next 2 years by the level of occupation-specific automation risk}

\begin{tabular}{|c|c|c|c|}
\hline \multirow[b]{2}{*}{ Questions on the probability of occupational changes } & \multicolumn{3}{|c|}{ Risk of automation } \\
\hline & $\underset{(<30 \%)}{\text { Low }}$ & $\underset{(30-70 \%)}{\text { Medium }}$ & $\underset{(>70 \%)}{\text { High }}$ \\
\hline Will you lose your job? & 17.39 & 22.05 & 23.03 \\
\hline Will you stop working in your current field and start working in a different one? & 8.91 & 12.10 & 14.63 \\
\hline Will you be demoted at your current place of employment? & 45.88 & 45.81 & 47.31 \\
\hline Will you attend courses or seminars to obtain additional training or qualifications? & 50.89 & 37.85 & 27.90 \\
\hline \begin{tabular}{|l|} 
Will you receive a salary or wage increase beyond the collectively negotiated wage increases? \\
\end{tabular} & 16.72 & 17.10 & 13.73 \\
\hline Will you start working on a self-employed and/or freelance basis? & 10.18 & 7.35 & 6.57 \\
\hline
\end{tabular}

\footnotetext{
${ }^{9}$ For instance, in Germany a much stricter dismissal protection legislation applies to employees at large firms more often than those at small firms [Bauernschuster, 2013]. If high-risk routine jobs are more likely to appear at large firms, then the people employed in such jobs may still be in a rather secure position, despite the high risk of automation of said jobs.

${ }^{10}$ Model III does not provide evidence of a possible non-linear relationship.
} 


\section{Table 4. Risk of automation of jobs and the probability of occupational changes within the next 2 years}

\begin{tabular}{|c|c|c|c|c|c|c|c|}
\hline \multirow[b]{2}{*}{ Parameters } & \multicolumn{7}{|c|}{ Self-reported (in t) probability of occupational changes within the next 2 years } \\
\hline & I & II & III & IV & V & VI & VII \\
\hline Occupation-specific probability of automation in $t$ & $\begin{array}{l}0.245^{\star * *} \\
(0.082)\end{array}$ & $\begin{array}{c}0.462^{\star * *} \\
(0.109)\end{array}$ & $\begin{array}{c}0.041 \\
(0.034)\end{array}$ & $\begin{array}{l}0.019^{*} \\
(0.010)\end{array}$ & $\begin{array}{c}-0.889^{* * *} \\
(0.092)\end{array}$ & $\begin{array}{l}-0.220^{\star *} \\
(0.104)\end{array}$ & $\begin{array}{l}-0.445^{\star * *} \\
(0.128)\end{array}$ \\
\hline $\begin{array}{l}\text { Occupation-specific probability of automation in } \\
t \text {, squared }\end{array}$ & \begin{tabular}{|c|}
$-0.211^{\star * *}$ \\
$(0.082)$
\end{tabular} & $\begin{array}{c}-0.288^{* * *} \\
(0.107)\end{array}$ & $\begin{array}{l}-0.024 \\
(0.034)\end{array}$ & - & $\begin{array}{c}0.553^{* * *} \\
(0.093)\end{array}$ & $\begin{array}{c}0.059 \\
(0.105)\end{array}$ & $\begin{array}{c}0.163 \\
(0.131)\end{array}$ \\
\hline Years of formal education & $\begin{array}{l}0.149^{* * *} \\
(0.025)\end{array}$ & $\begin{array}{l}0.171^{\star * *} \\
(0.032)\end{array}$ & $\begin{array}{l}0.006 \\
(0.009)\end{array}$ & $\begin{array}{l}0.006 \\
(0.009)\end{array}$ & $\begin{array}{l}0.314^{* * *} \\
(0.028)\end{array}$ & $\begin{array}{l}0.100^{* * *} \\
(0.031)\end{array}$ & $\begin{array}{l}0.168^{* * *} \\
(0.041)\end{array}$ \\
\hline Years of formal education, squared & $\begin{array}{c}-0.006^{* * *} \\
(0.001)\end{array}$ & $\begin{array}{c}-0.006^{* * *} \\
(0.001)\end{array}$ & $\begin{array}{l}0.000 \\
(0.000)\end{array}$ & $\begin{array}{l}0.000 \\
(0.000)\end{array}$ & $\begin{array}{c}-0.009^{* * *} \\
(0.001)\end{array}$ & $\begin{array}{c}-0.002^{*} \\
(0.001)\end{array}$ & $\begin{array}{c}-0.005^{\star * *} \\
(0.001)\end{array}$ \\
\hline Tenure & $\begin{array}{c}-0.032^{* * *} \\
(0.002)\end{array}$ & $\begin{array}{c}-0.036^{* * *} \\
(0.003)\end{array}$ & $\begin{array}{c}0.004^{* * *} \\
(0.001)\end{array}$ & $\begin{array}{c}0.004^{* * *} \\
(0.001)\end{array}$ & $\begin{array}{l}-0.003 \\
(0.002)\end{array}$ & $\begin{array}{c}-0.014^{* * *} \\
(0.003)\end{array}$ & $\begin{array}{c}-0.034^{\star * *} \\
(0.003)\end{array}$ \\
\hline Tenure, squared & $\begin{array}{c}0.001^{\star * *} \\
(0.000)\end{array}$ & $\begin{array}{c}0.001^{\star * *} \\
(0.000)\end{array}$ & $\begin{array}{c}-0.000^{* * *} \\
(0.000)\end{array}$ & $\begin{array}{c}-0.000^{* * *} \\
(0.000)\end{array}$ & $\begin{array}{c}0.000 \\
(0.000)\end{array}$ & $\begin{array}{l}0.000^{* *} \\
(0.000)\end{array}$ & $\begin{array}{c}0.000^{* * *} \\
(0.000)\end{array}$ \\
\hline Experience of unemployment, years & $\begin{array}{c}0.028^{\star * *} \\
(0.004)\end{array}$ & $\begin{array}{c}0.027^{* * *} \\
(0.005)\end{array}$ & $\begin{array}{l}0.004^{* *} \\
(0.002)\end{array}$ & $\begin{array}{l}0.004^{* *} \\
(0.002)\end{array}$ & $\begin{array}{c}-0.019^{\star * *} \\
(0.005)\end{array}$ & $\begin{array}{c}-0.030^{* * *} \\
(0.006)\end{array}$ & $\begin{array}{c}0.001 \\
(0.007)\end{array}$ \\
\hline Age & $\begin{array}{c}0.022^{\star * *} \\
(0.004)\end{array}$ & $\begin{array}{c}0.034^{\star \star *} \\
(0.006)\end{array}$ & $\begin{array}{c}0.016^{* * *} \\
(0.001)\end{array}$ & $\begin{array}{c}0.016^{* * *} \\
(0.001)\end{array}$ & $\begin{array}{c}0.024^{* * *} \\
(0.004)\end{array}$ & $\begin{array}{c}0.039^{* * *} \\
(0.005)\end{array}$ & $\begin{array}{c}0.047^{\star * *} \\
(0.007)\end{array}$ \\
\hline Age, squared & \begin{tabular}{|c|}
$-0.000^{\star * *}$ \\
$(0.000)$
\end{tabular} & $\begin{array}{c}-0.001^{* * *} \\
(0.000)\end{array}$ & $\begin{array}{c}-0.000^{* * *} \\
(0.000)\end{array}$ & $\begin{array}{c}-0.000^{* * *} \\
(0.000)\end{array}$ & $\begin{array}{c}-0.001^{* * *} \\
(0.000)\end{array}$ & $\begin{array}{c}-0.001^{* * *} \\
(0.000)\end{array}$ & $\begin{array}{c}-0.001^{\star * *} \\
(0.000)\end{array}$ \\
\hline Gender ( $=1$ if male, $=0$ if female $)$ & \begin{tabular}{|c|}
$-0.039^{\star * *}$ \\
$(0.014)$
\end{tabular} & $\begin{array}{l}-0.027 \\
(0.018)\end{array}$ & $\begin{array}{c}-0.032^{* * *} \\
(0.006)\end{array}$ & $\begin{array}{c}-0.032^{* * *} \\
(0.006)\end{array}$ & $\begin{array}{c}0.078^{* * *} \\
(0.016)\end{array}$ & $\begin{array}{c}0.144^{* * *} \\
(0.018)\end{array}$ & $\begin{array}{c}0.178^{* * *} \\
(0.023)\end{array}$ \\
\hline Nationality ( $=1$ if German, $=0$ if otherwise) & $\begin{array}{c}0.108^{* * *} \\
(0.026)\end{array}$ & $\begin{array}{l}0.070^{* *} \\
(0.035)\end{array}$ & $\begin{array}{c}0.007 \\
(0.011)\end{array}$ & $\begin{array}{c}0.007 \\
(0.011)\end{array}$ & $\begin{array}{c}0.247^{* * *} \\
(0.032)\end{array}$ & $\begin{array}{c}0.035 \\
(0.033)\end{array}$ & $\begin{array}{c}0.007 \\
(0.045)\end{array}$ \\
\hline Presence of children in the household & $\begin{array}{c}-0.091^{\star * \star} \\
(0.013)\end{array}$ & $\begin{array}{c}-0.081^{\star * *} \\
(0.017)\end{array}$ & $\begin{array}{l}-0.003 \\
(0.005)\end{array}$ & $\begin{array}{l}-0.003 \\
(0.005)\end{array}$ & $\begin{array}{c}-0.049^{* * *} \\
(0.014)\end{array}$ & $\begin{array}{c}-0.064^{\star * * *} \\
(0.016)\end{array}$ & $\begin{array}{c}0.007 \\
(0.021)\end{array}$ \\
\hline Willingness to take risks & $\begin{array}{c}0.001 \\
(0.003)\end{array}$ & $\begin{array}{c}0.017^{\star * *} \\
(0.004)\end{array}$ & $\begin{array}{c}-0.006^{* * *} \\
(0.001)\end{array}$ & $\begin{array}{c}-0.006^{* * *} \\
(0.001)\end{array}$ & $\begin{array}{c}0.020^{* * *} \\
(0.003)\end{array}$ & $\begin{array}{c}0.031^{\star * *} \\
(0.004)\end{array}$ & $\begin{array}{c}0.042^{* * *} \\
(0.005)\end{array}$ \\
\hline Conscientiousness & \begin{tabular}{|c|}
$-0.044^{\star * \star}$ \\
$(0.007)$
\end{tabular} & $\begin{array}{c}-0.082^{* * *} \\
(0.009)\end{array}$ & $\begin{array}{c}-0.013^{\star * *} \\
(0.003)\end{array}$ & $\begin{array}{c}-0.013^{* * *} \\
(0.003)\end{array}$ & $\begin{array}{l}-0.006 \\
(0.008)\end{array}$ & $\begin{array}{l}-0.004 \\
(0.009)\end{array}$ & $\begin{array}{c}-0.083^{\star * *} \\
(0.012)\end{array}$ \\
\hline Extraversion & \begin{tabular}{|c|}
$-0.021^{\star * *}$ \\
$(0.006)$
\end{tabular} & $\begin{array}{l}-0.002 \\
(0.007)\end{array}$ & $\begin{array}{c}-0.014^{\star * *} \\
(0.002)\end{array}$ & $\begin{array}{c}-0.014^{* * *} \\
(0.002)\end{array}$ & $\begin{array}{l}0.011^{*} \\
(0.007)\end{array}$ & $\begin{array}{c}0.024^{\star * *} \\
(0.007)\end{array}$ & $\begin{array}{l}-0.013 \\
(0.010)\end{array}$ \\
\hline Agreeableness & $\begin{array}{c}-0.013^{\star *} \\
(0.007)\end{array}$ & $\begin{array}{c}-0.027^{\star * *} \\
(0.008)\end{array}$ & $\begin{array}{c}0.001 \\
(0.003)\end{array}$ & $\begin{array}{c}0.001 \\
(0.003)\end{array}$ & $\begin{array}{l}-0.008 \\
(0.007)\end{array}$ & $\begin{array}{c}-0.036^{* * *} \\
(0.008)\end{array}$ & $\begin{array}{c}-0.046^{* * *} \\
(0.011)\end{array}$ \\
\hline Openness to experience & $\begin{array}{c}-0.017^{\star * *} \\
(0.006)\end{array}$ & $\begin{array}{c}0.043^{* * *} \\
(0.007)\end{array}$ & $\begin{array}{c}-0.006^{* *} \\
(0.002)\end{array}$ & $\begin{array}{c}-0.006^{* *} \\
(0.002)\end{array}$ & $\begin{array}{c}0.070^{\star * *} \\
(0.006)\end{array}$ & $\begin{array}{c}0.022^{\star * *} \\
(0.007)\end{array}$ & $\begin{array}{c}0.113^{\star * *} \\
(0.010)\end{array}$ \\
\hline Neuroticism (reversed emotional stability) & $\begin{array}{c}0.070^{* * *} \\
(0.005)\end{array}$ & $\begin{array}{c}0.069^{* * *} \\
(0.007)\end{array}$ & $\begin{array}{c}0.024^{* * *} \\
(0.002)\end{array}$ & $\begin{array}{c}0.024^{* * *} \\
(0.002)\end{array}$ & $\begin{array}{c}0.004 \\
(0.006)\end{array}$ & $\begin{array}{c}-0.030^{* * *} \\
(0.007)\end{array}$ & $\begin{array}{c}0.025^{* * *} \\
(0.009)\end{array}$ \\
\hline Internal locus of control & \begin{tabular}{|c|}
$-0.054^{\star * *}$ \\
$(0.007)$
\end{tabular} & $\begin{array}{c}-0.023^{* * *} \\
(0.009)\end{array}$ & $\begin{array}{c}-0.009^{* * *} \\
(0.003)\end{array}$ & $\begin{array}{c}-0.009^{* * *} \\
(0.003)\end{array}$ & $\begin{array}{c}0.008 \\
(0.008)\end{array}$ & $\begin{array}{c}0.012 \\
(0.009)\end{array}$ & $\begin{array}{l}-0.003 \\
(0.012)\end{array}$ \\
\hline External locus of control & $\begin{array}{c}0.062^{* * *} \\
(0.007)\end{array}$ & $\begin{array}{c}0.053^{* * *} \\
(0.009)\end{array}$ & $\begin{array}{c}0.012^{* * *} \\
(0.003)\end{array}$ & $\begin{array}{c}0.012^{* * *} \\
(0.003)\end{array}$ & $\begin{array}{c}-0.041^{* * *} \\
(0.008)\end{array}$ & $\begin{array}{l}-0.005 \\
(0.010)\end{array}$ & $\begin{array}{c}-0.037^{\star * *} \\
(0.013)\end{array}$ \\
\hline Year fixed effects & Yes $^{\star * *}$ & Yes $^{\star * *}$ & Yes $^{* * *}$ & Yes $^{\star * *}$ & Yes $^{* * *}$ & Yes $^{\star * *}$ & $\operatorname{Yes}^{* * *}$ \\
\hline Industry fixed effects & Yes $^{* * *}$ & $\operatorname{Yes}^{* * *}$ & Yes $^{* * *}$ & $\mathrm{Yes}^{* * *}$ & Yes $^{* * *}$ & $\operatorname{Yes}^{* * *}$ & $\mathrm{Yes}^{* * *}$ \\
\hline Constant & $\begin{array}{c}-1.617^{\star \star \star} \\
-0.203\end{array}$ & $\begin{array}{c}-2.712^{\star \star \star} \\
-0.263\end{array}$ & $\begin{array}{c}-0.480^{* * *} \\
-0.078\end{array}$ & $\begin{array}{c}-0.477^{\star * *} \\
-0.078\end{array}$ & $\begin{array}{c}-3.066^{* * *} \\
-0.227\end{array}$ & $\begin{array}{c}-2.390^{\star * *} \\
-0.253\end{array}$ & $\begin{array}{c}-3.098^{\star * *} \\
-0.346\end{array}$ \\
\hline Number of observations & 30890 & 30901 & 30677 & 30677 & 30885 & 30717 & 29600 \\
\hline Log Likelihood & -12.201 & -8.469 & -14.314 & -14.314 & -15.190 & -10.293 & -6.821 \\
\hline \multicolumn{8}{|c|}{$\begin{array}{l}\text { Questions on the probability of occupational changes: I — Will you lose your job?; II - Will you stop working in your current field and start working } \\
\text { in a different one?; } \text {;II }- \text { Will you be demoted at your current place of employment?; IV - Will you attend courses or seminars to obtain additional } \\
\text { training or qualifications?; } V-\text { Will you receive a salary or wage increase beyond the collectively negotiated wage increases?; VI - Will you start } \\
\text { working on a self-employed and/or freelance basis? } \\
{ }^{* * *} \mathrm{p}<0.01,{ }^{* *} \mathrm{p}<0.05,{ }^{*} \mathrm{p}<0.1 \text {. } \\
\text { Source: author's calculations. }\end{array}$} \\
\hline
\end{tabular}


At the same time, people in occupations with the highest and the lowest risks of automation are significantly more likely than people in jobs with a medium risk of automation to expect to gain additional qualifications in the near future (Column V). This observation may be indicative of a moderate risk of downward occupational mobility in the future, as people who urgently require additional skills in order to protect themselves from the negative effects of automation are likely to do so. ${ }^{11}$ Similarly, gaining additional qualifications may be also of high importance for people in occupations with a low risk of automation, in which computers strongly complement human labor. Moreover, a higher risk of automation is less likely to be associated with the probability of wage increases for individuals in those occupations (Column VI).

Finally, an interesting result was obtained with regard to the probability of setting up one's own business, namely, the respondents in occupations with a low risk of automation are significantly more likely than people in jobs with a high risk of automation to see themselves moving toward self-employment in the near future (Column VII). This is an important result that points toward opportunity-driven nascent entrepreneurship, since the willingness to set up one's own business is more pronounced among workers who are in relatively secure jobs in terms of their susceptibility to automation. Moreover, jobs with a low risk of automation include tasks requiring creativity, social interactions and abstract thinking, which are critically important for entrepreneurs.

As regards the effects of the control variables, it was observed that people with high and low levels of education are significantly less likely to expect occupational changes, as compared to individuals with middling levels of education. People with a longer tenure, males as well as those with children, have a lower probability of occupational changes. With regard to the effects of personality traits, people with higher levels of conscientiousness, agreeableness and an internal locus of control are less likely to expect occupational changes in the near future. The results for other personality traits are mixed. For instance, people with greater willingness to take risks report a higher probability of starting a job in a new field, obtaining additional qualifications, expecting a wage increase, and of becoming self-employed. ${ }^{12}$ On contrary, less risk-averse people report a lower probability of demotion at their current place of employment.

\section{Transitions to self-employment and unemployment}

While the previous section presented the results for expected occupational changes, in this section the analysis is focused on real occupational transitions from paid employment to unemployment and selfemployment within the next two years. The first column of Table 5 suggests that the high risk of automation in an occupation is more likely to lead to unemployment in the next two years. This relationship is linear, meaning that there is no decrease in the probability of unemployment for those workers who are in jobs with the highest risk of automation. ${ }^{13}$ Hence, it is likely that those workers underestimate the risk of losing their job, as has been shown in the Model I of Table 4.

Moreover, there is a statistically significant and negative relationship between the risk of automation and the transition from paid employment to self-employment. In order to provide a more differentiated picture of the relationship between the risk of automation and switches to self-employment, we additionally distinguish between self-employment with and without employees. The group of the solo self-employed may contain necessity-driven entrepreneurs, that is, those individuals who were at high risk of losing their jobs due to, for example, automation. On the contrary, the group of self-employed with employees is likely to contain opportunity-driven and growth-oriented entrepreneurs. Hence, one can expect different effects from automation risk on the various types of entrepreneurship. However, the results in Columns III and IV of Table 5 suggest that both types of entrepreneurs are likely to come from low-risk occupations, although the effect is lower (and only statistically significant at the $10 \%$ level) for the solo self-employed.

\section{Conclusions}

New and emerging technologies will lead to radical transformations on labor markets. As machines learn to accomplish not only routine tasks but also activities that require abstract skills and the ability to work in an unstructured environment, concerns arise that automation will wipe out a great number of jobs. This paper provided new evidence on the impact of the automation of jobs on individual-level occupational mobility. In particular, it shows that the expected probability of occupational changes rises with the occupationspecific risk of automation. This is particularly pronounced for such occupational changes as losing a job, demotion at one's current place of employment, or starting a new job in a different field. According to the respondents' own assessments, these changes are likely to occur within the next two years. This is quite in line with the prediction by Frey and Osborne [Frey, Osborne, 2013, 2017], who concluded that the current state of technology is such that it will be possible in the next 10-20 years to replace about half of the jobs in the US with machines.

\footnotetext{
${ }^{11}$ Unfortunately, the data does not provide information with regard to skills the respondents are going to improve or attain by means of attending additional training.

12 This is in line with previous studies (see, e.g., [Caliendo et. al., 2009]).

${ }^{13}$ A test of non-linearity proved to be insignificant in all model specifications of Table 5.
} 


\section{Table 5. Risk of the automation of jobs and transitions to self-employment and unemployment}

\begin{tabular}{|c|c|c|c|c|}
\hline \multirow{3}{*}{ Parameters } & \multicolumn{4}{|c|}{ Employment status in $(t+2)$} \\
\hline & Unemployed & Self-employed & $\begin{array}{c}\text { Self-employed } \\
\text { without employees }\end{array}$ & $\begin{array}{l}\text { Self-employed } \\
\text { with employees }\end{array}$ \\
\hline & I & II & III & IV \\
\hline Occupation-specific probability of automation in $\mathrm{t}$ & $\begin{array}{c}0.182^{* * *} \\
(0.061)\end{array}$ & $\begin{array}{c}-0.244^{* * *} \\
(0.079)\end{array}$ & $\begin{array}{l}-0.177^{*} \\
(0.092)\end{array}$ & $\begin{array}{c}-0.283^{\star *} \\
(0.111)\end{array}$ \\
\hline Years of formal education & $\begin{array}{c}-0.130^{* *} \\
(0.053)\end{array}$ & $\begin{array}{c}0.12 \\
(0.085) \\
\end{array}$ & $\begin{array}{l}0.185^{\star} \\
(0.104) \\
\end{array}$ & $\begin{array}{c}0.016 \\
(0.108) \\
\end{array}$ \\
\hline Years of formal education, squared & $\begin{array}{l}0.004^{*} \\
(0.002)\end{array}$ & $\begin{array}{l}-0.002 \\
(0.003)\end{array}$ & $\begin{array}{l}-0.005 \\
(0.004)\end{array}$ & $\begin{array}{c}0.001 \\
(0.004) \\
\end{array}$ \\
\hline Tenure & $\begin{array}{c}-0.062^{* * *} \\
(0.005)\end{array}$ & $\begin{array}{c}-0.034^{* * *} \\
(0.007)\end{array}$ & $\begin{array}{c}-0.048^{* * *} \\
(0.008)\end{array}$ & $\begin{array}{l}-0.009 \\
(0.009)\end{array}$ \\
\hline Tenure, squared & $\begin{array}{c}0.001^{\star * *} \\
(0.000)\end{array}$ & $\begin{array}{l}0.001^{* * *} \\
(0.000)\end{array}$ & $\begin{array}{c}0.001^{* * *} \\
(0.000)\end{array}$ & $\begin{array}{l}0.000 \\
(0.000)\end{array}$ \\
\hline Experience of unemployment, years & $\begin{array}{c}0.095^{\star * *} \\
(0.008)\end{array}$ & $\begin{array}{l}-0.01 \\
(0.014)\end{array}$ & $\begin{array}{l}-0.002 \\
(0.016)\end{array}$ & $\begin{array}{l}-0.028 \\
(0.025)\end{array}$ \\
\hline Age & $\begin{array}{c}-0.036^{\star * *} \\
(0.008)\end{array}$ & $\begin{array}{l}-0.001 \\
(0.013) \\
\end{array}$ & $\begin{array}{l}-0.008 \\
(0.015) \\
\end{array}$ & $\begin{array}{c}0.01 \\
(0.019) \\
\end{array}$ \\
\hline Age, squared & $\begin{array}{c}0.001^{* * *} \\
(0.000)\end{array}$ & $\begin{array}{l}0.000 \\
(0.000)\end{array}$ & $\begin{array}{c}0.000 \\
(0.000)\end{array}$ & $\begin{array}{l}0.000 \\
(0.000)\end{array}$ \\
\hline Gender (=1 if male, $=0$ if female) & $\begin{array}{c}0.034 \\
(0.035) \\
\end{array}$ & $\begin{array}{c}0.131^{* * *} \\
(0.047)\end{array}$ & $\begin{array}{l}0.087 \\
(0.054)\end{array}$ & $\begin{array}{l}0.176^{* *} \\
(0.070)\end{array}$ \\
\hline Nationality (=1 if German, = 0 if otherwise) & $\begin{array}{l}-0.043 \\
(0.058) \\
\end{array}$ & $\begin{array}{l}-0.107 \\
(0.088) \\
\end{array}$ & $\begin{array}{l}-0.032 \\
(0.117) \\
\end{array}$ & $\begin{array}{l}-0.176 \\
(0.110) \\
\end{array}$ \\
\hline Presence of children in the household & $\begin{array}{l}-0.058^{*} \\
(0.033)\end{array}$ & $\begin{array}{c}0.132^{\star * *} \\
(0.045)\end{array}$ & $\begin{array}{l}0.125^{* *} \\
(0.053)\end{array}$ & $\begin{array}{l}0.107^{*} \\
(0.063) \\
\end{array}$ \\
\hline Willingness to take risks & $\begin{array}{l}0.006 \\
(0.007) \\
\end{array}$ & $\begin{array}{c}0.058^{* * *} \\
(0.010)\end{array}$ & $\begin{array}{c}0.050^{* * *} \\
(0.011)\end{array}$ & $\begin{array}{c}0.059^{* * *} \\
(0.015)\end{array}$ \\
\hline Conscientiousness & $\begin{array}{l}-0.004 \\
(0.019)\end{array}$ & $\begin{array}{c}0.014 \\
(0.027)\end{array}$ & $\begin{array}{l}-0.006 \\
(0.031)\end{array}$ & $\begin{array}{c}0.042 \\
(0.038)\end{array}$ \\
\hline Extraversion & $\begin{array}{l}-0.019 \\
(0.014)\end{array}$ & $\begin{array}{l}0.017 \\
(0.020)\end{array}$ & $\begin{array}{l}-0.001 \\
(0.022)\end{array}$ & $\begin{array}{c}0.039 \\
(0.029)\end{array}$ \\
\hline Agreeableness & $\begin{array}{l}-0.017 \\
(0.016)\end{array}$ & $\begin{array}{l}-0.039^{*} \\
(0.023)\end{array}$ & $\begin{array}{l}-0.04 \\
(0.025)\end{array}$ & $\begin{array}{l}-0.032 \\
(0.034)\end{array}$ \\
\hline Openness to experience & $\begin{array}{l}0.014 \\
(0.014)\end{array}$ & $\begin{array}{c}0.088^{* * *} \\
(0.022)\end{array}$ & $\begin{array}{c}0.107^{\star * *} \\
(0.025)\end{array}$ & $\begin{array}{c}0.041 \\
(0.029) \\
\end{array}$ \\
\hline Neuroticism (reversed emotional stability) & $\begin{array}{l}0.028^{* *} \\
(0.013)\end{array}$ & $\begin{array}{c}0.022 \\
(0.018) \\
\end{array}$ & $\begin{array}{l}0.042^{* *} \\
(0.021) \\
\end{array}$ & $\begin{array}{l}-0.013 \\
(0.024) \\
\end{array}$ \\
\hline Internal locus of control & $\begin{array}{c}0.012 \\
(0.016)\end{array}$ & $\begin{array}{c}0.032 \\
(0.022) \\
\end{array}$ & $\begin{array}{c}0.023 \\
(0.025) \\
\end{array}$ & $\begin{array}{c}0.036 \\
(0.033) \\
\end{array}$ \\
\hline External locus of control & $\begin{array}{c}0.093^{* * *} \\
(0.017)\end{array}$ & $\begin{array}{l}-0.008 \\
(0.024) \\
\end{array}$ & $\begin{array}{l}-0.013 \\
(0.029) \\
\end{array}$ & $\begin{array}{c}0.002 \\
(0.032)\end{array}$ \\
\hline Year fixed effects & $\mathrm{Yes}^{* * *}$ & Yes $^{* * *}$ & Yes $* * *$ & Yes $* * *$ \\
\hline Industry fixed effects & Yes *** & Yes $* * *$ & Yes $* * *$ & Yes $* * *$ \\
\hline Constant & $\begin{array}{l}-0.23 \\
(0.418) \\
\end{array}$ & $\begin{array}{c}-4.279^{* * *} \\
(0.686)\end{array}$ & $\begin{array}{c}-4.443^{* * *} \\
(0.811)\end{array}$ & $\begin{array}{c}-3.927^{* * *} \\
(0.850)\end{array}$ \\
\hline Number of observations & 47123 & 47048 & 47048 & 46553 \\
\hline Log Likelihood & -5.219 & -2.796 & -1.816 & -1.323 \\
\hline $\begin{array}{l}\text { Notes: Dependent variable: Employment status } \\
{ }^{\star * \star} \mathrm{p}<0.01,{ }^{\star *} \mathrm{p}<0.05,{ }^{\star} \mathrm{p}<0.1 . \\
\text { Source: author’s calculations. }\end{array}$ & +2). Results & robit regression & Robust standard & rs in parenthese \\
\hline
\end{tabular}

An important question then concerns which additional skills workers in jobs at high risk of automation should acquire in order to make themselves less susceptible to the negative consequences of automation. The empirical results in this paper provide evidence that workers in high-risk occupations do indeed intend to gain additional qualifications and training in the near future. However, no information was available with regard to the type of training they were more likely to choose. Hence, more research is needed in order to develop educational strategies to make workers less susceptible to automation.

Moreover, this paper investigated the relationship between the automation of jobs and an individual's propensity to become an entrepreneur. The causes for the recent rise of entrepreneurial activities in many innovation-driven economies including Germany, and in particular, the rise of self-employment without employees, are still not entirely clear. There is also concern regarding the quality of such businesses without 
employees. For instance, a high risk of automation for certain jobs may drive entrepreneurial activities out of necessity. However, the result of this paper is that people in occupations at high risk of automation are significantly less likely than people in low-risk occupations to become nascent entrepreneurs and make the transition from paid employment to self-employment. This result holds for both self-employed with and without employees. It indicates that new technologies are likely to create new entrepreneurial opportunities in occupations that consist of tasks that are less likely to be computerized in the near future. Thus, the rising level of entrepreneurial activities is more likely to be driven by new technologies creating many new opportunities rather than by technology making jobs obsolete over the course of automation.

\section{References}

Acs Z.J. (2011) High-impact Firms: Gazelles Revisited. Elgar Handbook of Research on Entrepreneurship and Regional Development - National and Regional Perspectives (ed. M. Fritsch), Cheltenham: Edward Elgar, pp. 133-174.

Arntz M., Gregory T., Zierahn U. (2016) The Risk of Automation for Jobs in OECD Countries: A Comparative Analysis (OECD Social, Employment and Migration Working Paper no 189), Paris: OECD. DOI: http://dx.doi.org/10.1787/5jlz9h56dvq7en.

Åstebro T., Thompson P. (2011) Entrepreneurs, Jacks of All Trades or Hobos? Research Policy, vol. 40, pp. 637-649.

Audretsch D.B., Thurik A.R. (2000) Capitalism and democracy in the 21 st century: From the managed to the entrepreneurial economy. Journal of Evolutionary Economics, vol. 10, pp. 17-34.

Audretsch D.B., Thurik A.R. (2001) What is new about the new economy: Sources of growth in the managed and entrepreneurial economies. Industrial and Corporate Change, vol. 10, pp. 267-315.

Autor D.H. (2015) Why Are There Still So Many Jobs? The History and Future of Work-place Automation. Journal of Economic Perspectives, vol. 29, no 3, pp. 3-30.

Autor D.H. (2014) Polanyi's Paradox and the Shape of Employment Growth (NBER Working Paper no 20485), Cambridge, MA: National Bureau of Economic Research.

Autor D.H., Dorn D. (2013) The Growth of Low-Skill Service Jobs and the Polarization of the US Labor Market. American Economic Review, vol. 103, no 5, pp. 1553-1597.

Autor D.H., Levy F., Murnane R.J. (2003) The Skill Content of Recent Technological Change: An Empirical Exploration. Quarterly Journal of Economics, vol. 118, no 4, pp. 1279-1333.

Bauernschuster S. (2013) Dismissal protection and small firms' hirings: Evidence from a policy reform. Small Business Economics, vol. 40, no 2, pp. 293-307.

Baumol W.J. (2004) Entrepreneurial enterprises, large established firms and other components of the free-market growth-machine. Small Business Economics, vol. 23, pp. 9-21.

Brynjolfsson E., McAfee A. (2014) Race Against the Machine: How the Digital Revolution is Accelerating Innovation, Driving Productivity, and Irreversibly Transforming Employment and the Economy, New York: W. W. Norton \& Company.

Caliendo M., Fossen F.M., Kritikos A.S. (2009) Risk attitudes of nascent entrepreneurs - New evidence from an experimentally-validated survey. Small Business Economics, vol. 32, no 2, pp. 153-167.

Caliendo M., Kritikos A.S. (2010) Start-Ups by the Unemployed: Characteristics, Survival and Direct Employment Effects. Small Business Economics, vol. 35, no 1, pp. 71-92.

Chang J.-H., Huynh P. (2016) ASEAN in Transformation: The Future of Jobs at Risk of Automation. Bureau for Employers' Activities (Working Paper no 9), Geneve: Internaltional Labour Office.

Costa P.T., McCrae R.R. (1992) Revised NEO personality inventory (NEO-PI-R) and NEO five factor inventory (NEOFFI) professional manual, Odessa, FL: PAR.

Dengler K., Matthes B. (2015) Folgen der Digitalisierung für die Arbeitswelt. Substitu-ierbarkeitspotentiale von Berufen in Deutschland (IAB Forschungsbericht 11/2015), Nuremberg: Institute for Employment Research.

Frey C.B., Osborne M.A. (2013) The future of employment: How susceptible are jobs to computerisation?, Oxford, UK: University of Oxford.

Frey C.B., Osborne M.A. (2017) The future of employment: How susceptible are jobs to computerisation?, Technological Forecasting and Social Change, vol. 114, pp. 254-280.

Fritsch M. (2011) The Effect of New Business Formation on Regioonal Development: empirical evidence, interpretation, and avenues for further research. Elgar Handbook of Research on Entrepreneurship and Regional Development National and Regional Perspectives (ed. M. Fritsch), Cheltenham: Edward Elgar, pp. 133-174.

Fritsch M., Kritikos A.S., Rusakova A. (2012) Who Starts a Business and Who is Self-Employed in Germany? (Jena Economic Research Paper 001-2012), Jena: Friedrich Schiller University; Max Planck Institute of Economics.

Fritsch M., Kritikos A.S., Sorgner A. (2015) Why did self-employment increase so strongly in Germany? Entrepreneurship and Regional Development, vol. 27, pp. 307-333.

Gerlitz J.Y., Schupp J. (2005) Zur Erhebung der Big-Five-basierten Persönlichkeits-merkmale im SOEP (Research Notes), Berlin: German Institute for Economic Research.

Goos M., Manning A., Salomons A. (2014) Explaining Job Polarization: Routine-Biased Technological Change and Offshoring. American Economic Review, vol. 104, no 8, pp. 2509-2526.

Pajarinen M., Rouvinen P., Ekeland A. (2015) Computerization Threatens One-Third of Finnish and Norwegian Employment (ETLA Brief no 34), Helsinki: Research Institute of the Finnish Economy.

Papke L.E., Wooldridge J.M. (1996) Econometric Methods for Fractional Response Variables with an Application to 401(k) Plan Participation Rates. Journal of Applied Econometrics, vol. 11, no 6, pp. 619-632.

Parker S.C. (2009) The Economics of Entrepreneurship, Cambridge: Cambridge University Press.

Shane S. (2000) Prior Knowledge and the Discovery of Entrepreneurial Opportunities. Organization Science, vol. 11, no 4 , pp. $448-469$.

Shane S. (2009) Why encouraging more people to become entrepreneurs is bad public policy. Small Business Economics, vol. 33, pp. 141-149.

Sorgner A., Bode E., Krieger-Boden C. (2017a) The Effects of Digitalization on Gender Equality in the G20 economies. Kiel: Kiel Institute for the World Economy.

Sorgner A., Fritsch M., Kritikos A.S. (2017b) Do Entrepreneurs Really Earn Less? Small Business Economics, 2017, vol. 49, no 2, pp. 251-272. DOI 10.1007/s11187-017-9874-6.

Wagner, G.G., J.R. Frick, and J. Schupp (2007) The German Socio-Economic Panel Study (SOEP) - Scope, Evolution and Enhancements. Schmollers Jahrbuch, vol. 127, no 1, pp. 139-169.

Welter F. (2006) Women's entrepreneurship in Germany: Progress in a still traditional environment. Growthoriented Women Entrepreneurs and Their Businesses: A Global Research Perspective (eds. C.G. Brush, N.M. Carter, E.J. Gatewood, P.G. Greene, M.M. Hart), Cheltenham: Edward Elgar, pp. 128-153. 


\section{TECHNOLOGICAL ENTREPRENEURSHIP: FACTORS OF GROWTH}
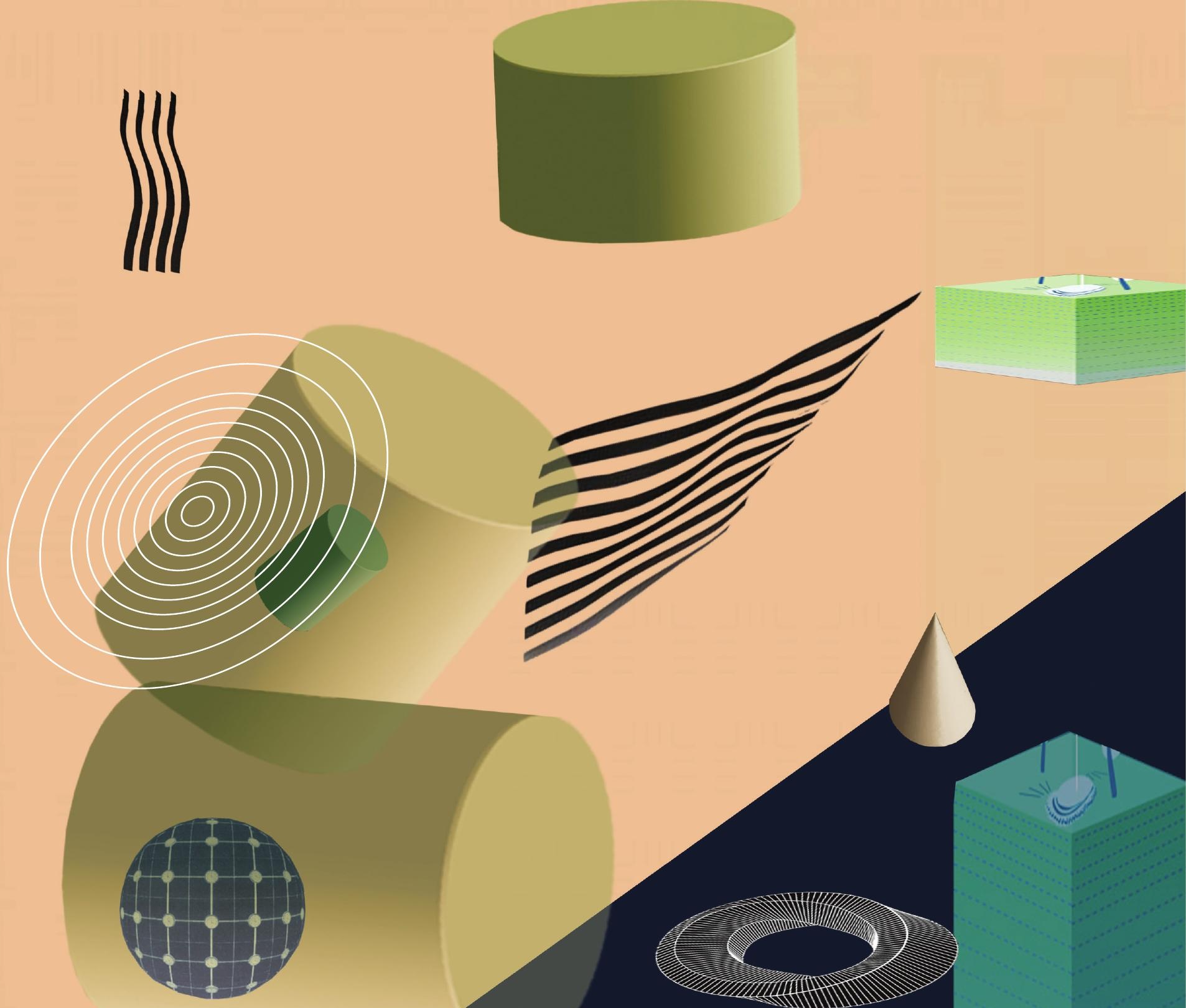


\title{
The Aspirations of New Technology-Based Firms in CEE and CIS Countries
}

\author{
Przemysław Zbierowski \\ Associate Professor, przemyslaw.zbierowski@ue.katowice.pl \\ University of Economics in Katowice, 1 Maja 50, 40-287 Katowice, Poland.
}

\begin{abstract}
$\mathrm{T}$ he main purpose of this paper is to assess the possible impact of new technology-based firms on the social and economic development of Central and Eastern European (CEE) and Commonwealth of Independent States (CIS) countries by analyzing the share of such firms among entrepreneurs and society and by investigating data on their expected growth, innovativeness, and internationalization. The study contributes to forecasting the future effects caused by NTBFs on the economy of CEE and CIS countries. We use pooled samples from 2013-2015 from the Global Entrepreneurship Monitor for: Russia (pooled sample size: 4,030), Hungary (6,003), Romania $(6,024)$, Poland $(6,001)$, Lithuania $(4,000)$, Latvia $(4,004)$, Estonia $(6,662)$, Czech Republic $(5,009)$, Slovakia $(6,010)$, and Kazakhstan $(4,205)$. Most analyses are based on a oneway ANOVA analysis of the differences in the average size of country indicators for the analyzed countries.

The research results point to significant differences among the analyzed countries. The share of NTBF

owners ranges from $0.7 \%$ (Russia) to almost 5\% (Slovakia, Romania, and Kazakhstan). NTBFs also substantially differ across countries in terms of projected growth (highest in Hungary and lowest in Russia), internationalization (highest in Latvia, lowest in Russia) and innovativeness (highest in Poland, lowest in Kazakhstan). The main limitations of this study are as follows. The sample used was not chosen specifically for the task. Moreover, the assessment of the novelty of the technology is based on the entrepreneur's self-assessment, so we might expect a bias in that regard. The data on projected growth, internationalization, and innovations are just the expectations of the entrepreneurs themselves, so again, bias is expected. The relationships presented in the paper might be strongly influenced by external factors and sample pooling might even magnify that impact. The paper has implications for the policies developed to support entrepreneurship in order to facilitate growth, internationalization, and innovativeness at NTBFs.
\end{abstract}

Keywords: new technology-based firms (NTBFs); early entrepreneurs; CIS countries; CEE countries; innovation; internationalisation.
Citation: Zbierowski P. (2017) The Aspirations of New Technology-Based Firms in CEE and CIS Countries? Foresight and STI Governance, vol. 11, no 3, pp. 50-60. DOI: 10.17323/2500-2597.2017.3.50.60 
$\mathrm{N}$ ew technology-based firms (NTBFs) constitute one of the fastest growing areas in entrepreneurship literature as they are critically important for socioeconomic development. Increasing the number of rapid-growing NTBFs is one of the key priorities of the innovation policy adopted by the European Commission [Grilli, 2014].

Meanwhile, the actual state of and aspirations for ventures started up by entrepreneurs with the use of new technologies in the countries of Central and Eastern Europe (CEE) and the Commonwealth of Independent States (CIS) is a less researched topic. The main purpose of this paper is to assess the possible impact of NTBFs on the social and economic development of the CEE and CIS countries, comparing the share of NTBFs among early entrepreneurs, their aspirations regarding growth, innovativeness, and internationalization. As the paper is rather descriptive, it does not necessarily follow the classic structure of an academic paper. I do not formulate hypotheses, instead, I look at patterns and attempt to jointly analyze and compare various results.

The situation of CEE and CIS countries with regard to business start-ups and especially NTBFs is somewhat special. Aidis, Estrin and Mickiewicz [Aidis et al., 2008, 2012] point out the weak institutions in those countries and argue that the institutional environment is important in explaining the levels of entrepreneurship development. Moreover, they make an observation that freedom from corruption is significantly related to entrepreneurial entry. Estrin, Mickiewicz and Stephan [Estrin et al., 2013] attribute the possible lower levels of entrepreneurial activity to lower levels of social capital (associated with the past's lower level of social entrepreneurship) and the lack or imperfection of formal institutions such as strong property rights. In addition, the technological environment does not support NTBFs as most CEE and CIS countries still have not developed effective frameworks for research and development (R\&D) funding and support at the national level, which is reflected in the low percentage of GDP spent on R\&D (the highest CEE and CIS country in that regard is Czech Republic with about 2\% of GDP spent on R\&D).

\section{Approach}

To undertake an in-depth investigation into the phenomenon of NTBFs, I decided to use data from the Global Entrepreneurship Monitor (GEM). It allows one to investigate entrepreneurs at the very earliest stages of their activity, even before they formally establish a new enterprise [Reynolds, 2017]. Moreover, GEM gathers data based on a representative random sample of at least 2,000 adults in each country taking part in the project each year, which allows one to both compare countries and capture the dynamics of the processes [Kelley et al., 2016]. Finally, using the GEM methodology, one is able to identify those entrepreneurs that use new technologies. The basis for distinguishing start-ups using new technologies is a question included in the APS questionnaire: "How long have the technologies or procedures required for this product or service been available?"'. The GEM does not purposefully identify or define new technology-based firms and makes no separate attempt to analyze ventures using new technologies. NTBFs are elsewhere defined as ventures recently established by a group of entrepreneurs, based on the exploitation of an invention or technological innovation and as firms that employ a high proportion of qualified employees [Campos et al., 2011]. Throughout the paper I use the term NTBF to describe the new venture (up to three and a half years of age) using a technology that has been available for at most five years.

The cyclical research within the framework of the Global Entrepreneurship Monitor allows one to track the dynamics of the analyzed phenomena. However, in order to analyze the characteristics of the entrepreneurs using new technologies, sets of data from 2013-2015 have been accumulated. Such a collection provides a larger research sample, while the period between the outermost points of the study is not too long, so it can be assumed that the external conditions for running a business have not changed substantially. The collection of the research samples resulted in a total sample of 51,948 respondents in CEE and CIS countries. Within this sample, 5,183 persons have been identified as early stage entrepreneurs and included in the TEA (Total Early Stage Entrepreneurial Activity) measure (9.98\%), which covers all entrepreneurs on the market for up to three and a half years, and is further divided into nascent entrepreneurs (up to six months of activity) and new business owners (six months to three and a half years of activity). Among these persons, 628 entrepreneurs declared using the newest technologies (technologies up to one year old) (1.2\% of the total sample, $12.1 \%$ of TEA) while 1,102 reported using new technologies (between one to five years old) ( $2.1 \%$ of the total sample, $21.3 \%$ of TEA). The rest, 3,453 TEA entrepreneurs, declared using technologies invented more than five years ago.

The GEM also distinguishes between the levels of technology for the sector of activity of the entrepreneur, which could also be used as an indicator of the quality of the start-up. However, only 197 entrepreneurs in high-tech industries were identified (3.8\% of TEA) and due to that small number, such a distinction is not appropriate for analysis. In view of such results, it is most expedient to combine the groups of entrepreneurs using the newest and new technologies and analyze them together. There are 1,730 such entrepreneurs in the CEE and CIS sample, which constitutes the foundation for statistical analysis. Moreover, in some cases, taking into consideration only the entrepreneurs using the latest technologies would result in very small numbers of respondents (for example, Russia only has four such persons).

The present study pertains to the comparison of entrepreneurs using new technologies and those using solely technologies that have been available for at least five years. Moreover, CEE and CIS countries are compared to find some interesting patterns in their high-tech entrepreneurship. The subjects of study are 10 CEE, CIS and former USSR countries: Russia (pooled sample size: 4,030), Hungary $(6,003)$, Romania

\footnotetext{
1 There are three possible answers: "less than a year", "between one to five years", "longer than five years". Depending on the answer given, GEM divides entrepreneurs into those using newest technologies (up to one year), new technologies (one to five years) and those not using new technologies (more than five years).
} 
Table 1. Total, TEA, and high-tech TEA sample sizes in CEE and CIS countries, 2013-2015

\begin{tabular}{|l|c|r|r|r|r|c|}
\hline \multicolumn{1}{|c|}{ Country } & $\begin{array}{c}\text { Sample } \\
\text { size }\end{array}$ & $\begin{array}{c}\text { All } \\
\text { TEA }\end{array}$ & High-tech TEA & TEA & High-tech as \% of TEA & $\begin{array}{c}\text { High-tech as \% of total } \\
\text { population }\end{array}$ \\
\hline Russia & 4030 & 210 & 29 & 5.21 & 13.81 & 0.72 \\
\hline Hungary & 6003 & 533 & 101 & 8.88 & 18.95 & 1.68 \\
\hline Romania & 6024 & 636 & 281 & 10.56 & 26.01 & 4.66 \\
\hline Poland & 6001 & 569 & 148 & 9.48 & 22.68 & 2.47 \\
\hline Lithuania & 4000 & 472 & 165 & 11.80 & 36.61 & 3.13 \\
\hline Latvia & 4004 & 538 & 122 & 13.44 & 34.99 & 3.05 \\
\hline Estonia & 6662 & 702 & 257 & 10.54 & 48.50 & 3.86 \\
\hline Czech Republic & 5009 & 403 & 141 & 8.05 & 37.45 & 2.81 \\
\hline Slovakia & 6010 & 602 & 292 & 10.02 & & 4.86 \\
\hline Kazakhstan & 4205 & 518 & 194 & 12.32 & & \\
\hline
\end{tabular}

(6,024), Poland (6,001), Lithuania (4,000), Latvia (4,004), Estonia (6,662), Czech Republic (5,009), Slovakia $(6,010)$, and Kazakhstan $(4,205)$. Bulgaria and Georgia have been excluded from the list due to the fact that during the research period in question (2013-2015) they participated in the survey only once, resulting in samples of 2,002 and 2,016 respondents, respectively. Also, Georgia left the CIS in 2008. Baltic countries (Lithuania, Latvia, and Estonia) officially do not belong to CEE, it is however interesting to take them into consideration given that they are former USSR countries and are economically similar to CEE countries. Sample sizes for countries differ as some countries took part in the research survey three times in 2013 2015 (Hungary, Romania, Poland, Estonia and Slovakia) and some countries only participated twice (Russia, Lithuania, Latvia, Czech Republic and Kazakhstan). Sample sizes, the numbers of TEA respondents, and high-tech TEA respondents are presented in Table 1. The results for TEA and high-tech TEA are unweighted, therefore they will slightly differ from official GEM results for which calculating weights are used.

As it can be seen, the TEA and high technology venture results differ substantially among the studied countries. Traditionally the lowest TEA rate in the region is experienced by Russia along with the lowest share of high-tech ventures. The highest TEA is observed in the Baltic countries, but also in Kazakhstan. In terms of the share of high-tech ventures in Romania and Slovakia, it surpasses $40 \%: 44.18 \%$ and $48.5 \%$, respectively.

\section{Socio-demographic characteristics of high-tech entrepreneurs in CEE and the CIS}

Gender and age usually play an important role in the analysis of early entrepreneurs, as they often determine human and social capital. Marlow and McAdam [Marlow, McAdam, 2012] take a feminist perspective in analyzing high-tech female entrepreneurship, but admit that women are the minority when it comes to high-tech business ownership. Mayer [Mayer, 2008] argues that female entrepreneurs are more likely to start firms in predominately female high-tech sectors than in male-dominated high-tech sectors. Moreover, female-dominated high-tech firms are smaller and less profitable than their male counterparts. On the other hand, Tan [Tan, 2008] argues that female entrepreneurs are more willing to take risks that are also associated with using new technologies, which might suggest that the percentage of women among high technology entrepreneurs might be higher than in the group of low technology entrepreneurs. Figure 1 presents the share of male entrepreneurs among high-tech and low-tech venture owners in CEE and CIS countries.

The differences in the shares of male entrepreneurs in high-tech and low-tech ventures are not substantial with two exceptions: Lithuania and Latvia, where there is a larger share of women involved in high-tech start-ups in Latvia, while in Lithuania there is a larger share of men. It is also worth noting that in two CIS countries, Russia and Kazakhstan, the share of women starting up a business is the highest, but also the share of women in high-tech ventures is higher than in low-tech ventures. In Kazakhstan, women starting up a high-tech venture are even in majority, although it must be said that the difference is not statistically significant with a 0.95 confidence interval.

There is some evidence that ventures using new and high technologies are more often started by young entrepreneurs [Cannone et al., 2014; Ouimet, Zarutskie, 2014]. That is partly because young people have a better understanding of new technologies, but also because they are more internationally oriented and tend to import new technologies [Cannone et al., 2014]. Figure 2 presents the research results concerning this phenomenon.

As assumed, in most cases the share of young people (up to 35 years of age) establishing a high-tech business is higher than in low-tech ventures. In Poland, where it is the highest, two thirds of high-tech ventures are started by people in their twenties and early thirties and $27 \%$ of them are started by people under 25 years of age. The two exceptions are Latvia, where high-tech ventures are started on average by people older than those who start low-tech ventures, and Kazakhstan, where there is no difference in that respect.

\section{Self-assessment, the cultural perception of entrepreneurship, and the motives for starting a business in CEE and CIS countries}

Part of the decision to start a business is determined by a potential entrepreneur's self-assessment and on their perception of the external environment, that is, whether or not it would support or hinder the 


\section{Figure 1. Percentage of male respondents among high- and low-tech entrepreneurs} in CEE and CIS countries, 2013-2015

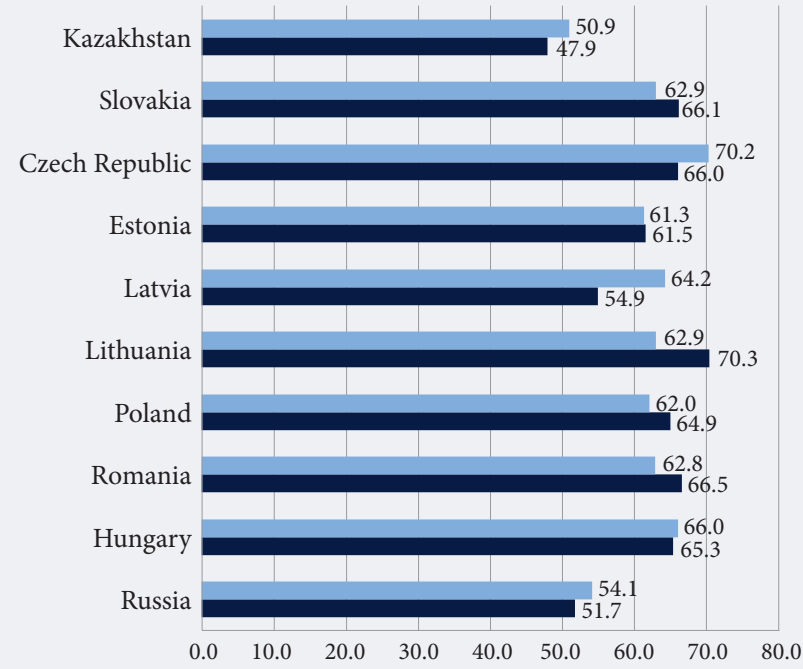

Low tech companies

- High tech companies

Source: compiled by the author.

running of one's own business [Ajzen, 1991, 2011]. Therefore, it is worth analyzing the differences between individual perceptions and the perceptions of a country's business climate by both high-tech and low-tech entrepreneurs by referring to the rate of TEA and high-tech ventures. For these and the following analyses, I use a one-way ANOVA analysis to statistically check the significance of the differences in the average indicators. For each analysis, I present descriptive statistics referring to high-tech venture owners, but I also present sample sizes and averages for low-tech entrepreneurs for the purpose of comparison. Tables 2 and 3 present the results of the analysis of average indicators of the individual perceptions of an entrepreneur. It is reflected in the GEM variable INDSUPyy (Individual Perception of Entrepreneurship Index) ranging from 0 to 3 points and is the result of a few questions referring to knowing other entrepreneurs, perceiving opportunities for business, overcoming the fear of failure, and possessing the appropriate knowledge and skills for running a business.

The results of the one-way ANOVA analysis indicate that there are some statistically significant differences among countries in terms of the self-assessments of entrepreneurs. The highest is the self-assessment in two CIS countries: Russia and Kazakhstan. However, in the case of Russia, a high self-assessment is coupled with the lowest TEA score, while in Kazakhstan, it coincides with one of the highest. Also, in Russia the difference between self-assessments by high-tech entrepreneurs and low-tech entrepreneurs is the highest. On the other hand, in case of Hungary, the self-assessment of entrepreneurs is the lowest for both high-tech

\section{Figure 2. Percentage of entrepreneurs under 35 years of age in CEE} and CIS countries, 2013-2015 (\%)

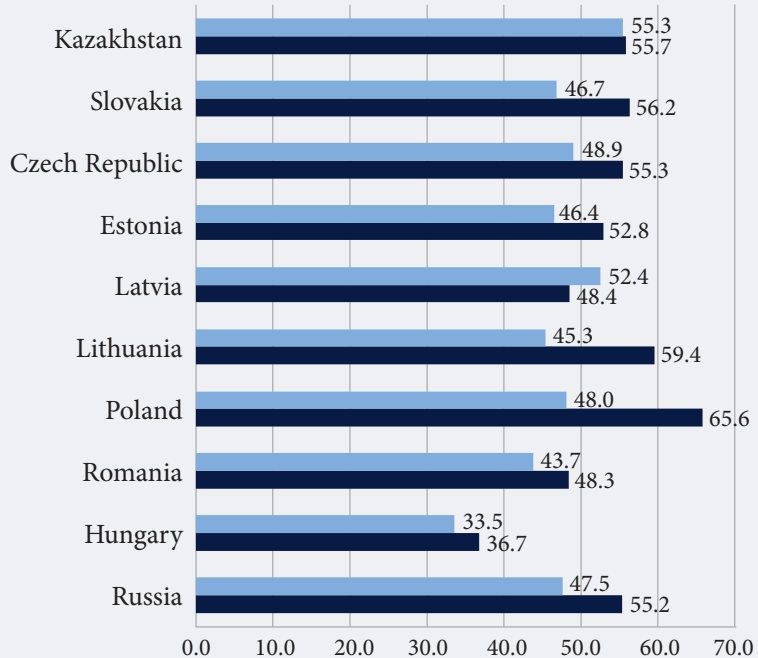

- Low tech companies

- High tech companies

Source: compiled by the author. 
Table 2. Descriptive statistics for individual self-assessment by entrepreneurs in CEE and CIS countries, 2013-2015

\begin{tabular}{|c|c|c|c|c|c|c|c|c|}
\hline Countries & $\begin{array}{l}\mathrm{N} \text { (high } \\
\text { tech) }\end{array}$ & Mean (high tech) & N (low tech) & Mean (low tech) & SD & SE & $\begin{array}{c}\text { 95\% CR } \\
\text { (low tech) }\end{array}$ & $\begin{array}{c}\text { 95\% CR } \\
\text { (high tech) }\end{array}$ \\
\hline Russia & 26 & 2.38 & 138 & 2.09 & 0.804 & 0.158 & 2.06 & 2.71 \\
\hline Hungary & 87 & 1.69 & 350 & 1.75 & 0.919 & 0.099 & 1.49 & 1.89 \\
\hline Romania & 262 & 1.99 & 320 & 1.84 & 0.835 & 0.052 & 1.89 & 2.09 \\
\hline Poland & 124 & 2.12 & 325 & 2.07 & 0.792 & 0.071 & 1.98 & 2.26 \\
\hline Lithuania & 144 & 1.88 & 247 & 1.93 & 0.960 & 0.080 & 1.72 & 2.03 \\
\hline Latvia & 104 & 2.06 & 346 & 1.87 & 0.857 & 0.084 & 1.89 & 2.22 \\
\hline Estonia & 213 & 2.21 & 356 & 2.25 & 0.815 & 0.056 & 2.10 & 2.32 \\
\hline Czech Republic & 122 & 1.97 & 227 & 1.86 & 0.852 & 0.077 & 1.81 & 2.12 \\
\hline Slovakia & 259 & 1.90 & 254 & 1.94 & 0.848 & 0.053 & 1.80 & 2.00 \\
\hline Kazakhstan & 148 & 2.51 & 219 & 2.37 & 0.742 & 0.061 & 2.39 & 2.63 \\
\hline Total & 1489 & 2.05 & 2782 & 1.98 & 0.865 & 0.022 & 2.01 & 2.09 \\
\hline
\end{tabular}

and low-tech venture owners. Moreover, Hungary is a country where high-tech entrepreneurs have lower individual self-assessments than do low-tech entrepreneurs.

Tables 4 and 5 present the results of the analysis of the perception of the cultural environment, based on the GEM variable CULSUPyy (Cultural Support for Entrepreneurship Index). It is ranged from 0 to 3 points and based on the results of such questions concerning the preference for equal standards of living in society, starting a new business being a desirable career choice, the high social status and respect for those who successfully start a new business, and media coverage of stories about successful new businesses.

The results of cultural perception of entrepreneurship are very similar to results of individual self-assessment by entrepreneurs in those countries. The highest score was achieved by Kazakhstan and then Russia although in the second case the result is much lower than in the individual self-assessment and furthermore was lower among high-tech entrepreneurs than among low-tech entrepreneurs. That phenomenon might be caused by the fact that high-tech entrepreneurs in Russia must overcome greater barriers hindering entrepreneurial activity. The lowest scores for cultural assessment were demonstrated by Hungary, then Poland, Estonia, and Slovakia.

Those low results were also confirmed by the low assessment of entrepreneurial framework conditions (EFCs) by GEM experts in those countries. However, the low assessment and low scores in terms of cultural support does not prevent those countries from achieving strong TEA levels, although in the case of Hungary, this might be the result of a low number of high-tech entrepreneurs.

The GEM methodology makes a distinction between opportunity-based and necessity-based entrepreneurship. The first type is connected with pursuing opportunities - having a good idea for a business and identifying a gap on the market. The second type of entrepreneurship is more or less 'enforced' by a lack of employment or a lack of skills that prevents one from finding satisfactory employment. There is some, albeit fragmented and limited, evidence that high technology ventures are more often based on opportunity rather than on necessity (e.g., [Groen et al., 2008; Gruber, Henkel, 2008]). Intuitively we can assume that the use of new technologies is associated with pursuing opportunity rather than with being pushed into entrepreneurial activity by external circumstances. Figure 3 presents a comparison of the share of opportunity-based entrepreneurs within the high-tech and low-tech groups.

The results confirm our assumptions only to some extent. In some cases, the share of opportunity-based entrepreneurs in the high-tech group is higher than it is in the low-tech group. The biggest difference in that regard is observed in Poland, but large differences exist also in Hungary, the Czech Republic and Kazakhstan. However, for two countries (Russia and Slovakia) the results are contradictory - more opportunity entrepreneurs are observed among low-tech ventures than among high-tech ones. This result might be explained by two distinct factors. In Russia, the TEA indicator is very low, also the share of hightech ventures in the TEA is low. This fact results in a low number of high-tech ventures in general. Therefore, for external, mainly economic reasons, using new technologies might not be considered a good choice and more entrepreneurs often are 'pushed' into using new technologies in order to be competitive on the market. In case of Slovakia, the situation is very different: the distribution of opportunity-based and necessity-based ventures among these two groups of early entrepreneurs is more due to industry or regional conditions. An

Table 3. Results of the one-way ANOVA analysis of individual self-assessment by entrepreneurs in CEE and CIS countries, 2013-2015

\begin{tabular}{|l|r|r|r|r|r|}
\hline & Sum of squares & \multicolumn{1}{c|}{ df } & Mean square & \multicolumn{1}{c|}{ F } & Sig. \\
\hline Between groups & 63.831 & 9 & 7.092 & 9.985 & 0.000 \\
\hline Within groups & 1050.491 & 1479 & 0.710 & & \\
\hline Total & 1114.322 & 1488 & & & \\
\hline Source: compiled by the author.
\end{tabular}




\section{Figure 3. Percentage of opportunity-based ventures in CEE and CIS countries, 2013-2015}

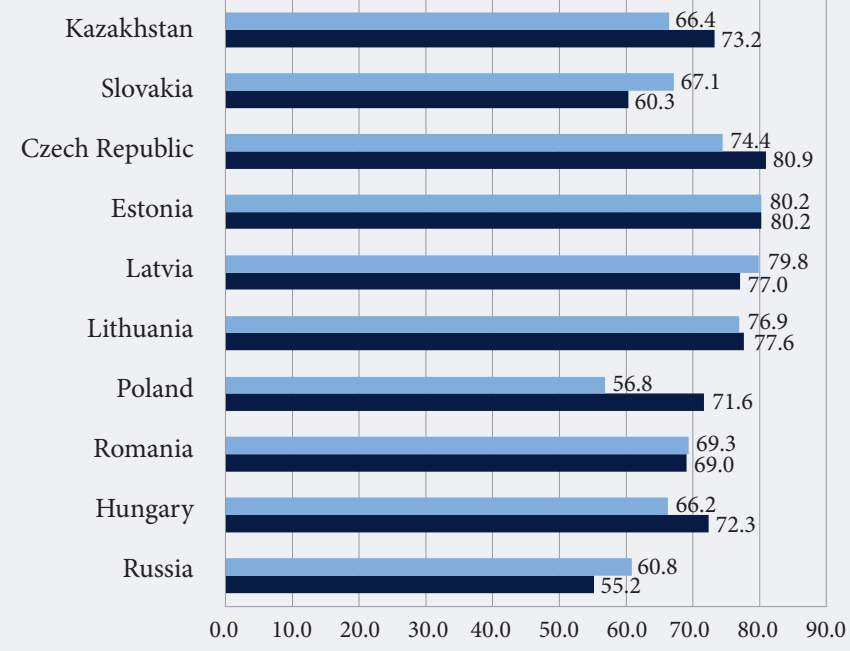

- Low tech companies

- High tech companies

Source: compiled by the author.

explanation might also be found in the geography of the region and the ease of moving entrepreneurial activity to one of the neighboring countries.

\section{Aspirations of high-tech entrepreneurs to grow, innovate and to enter international markets}

GEM projects also focused on the aspirations of the entrepreneurs. This encompasses three types of projections (in the case of nascent entrepreneurs) and assessments (in the case of new business owners): the number of jobs that an entrepreneur wants to create over the next five years (and the current number of jobs as a point of reference), internationalization (the share of customers from outside of the country) and product innovations (the share of customers that consider the product new or unfamiliar). Those three types of aspirations contribute to the quality of the venture. Therefore, the central question that should be asked is: What are the aspirations of high-tech entrepreneurs in CEE and CIS countries?

The first and probably the most obvious, is the association of new technologies and new products. What is especially challenging though is the question of the order in which the process of new product development takes place: are new products 'pushed' forward by new technologies or are new technologies 'pulled' in by new products? There is some evidence to support the first thesis [Gupta, Wilemon, 1990]. In accordance with the GEM's methodology, product innovation is measured by the following question: How many (potential) customers consider your product new or unfamiliar? $(1-$ all, 2 - some, 3 - none). Therefore, the higher the score, the less innovative the product. The results of the one-way ANOVA analysis are presented in Tables 6 and 7.

\section{Table 4. Descriptive statistics for the cultural perception of entrepreneurship in CEE} and CIS countries, 2013-2015

\begin{tabular}{|c|c|c|c|c|c|c|c|c|}
\hline Countries & $\begin{array}{c}\mathrm{N} \text { (high } \\
\text { tech) }\end{array}$ & Mean (high tech) & $\mathrm{N}$ (low tech) & Mean (low tech) & SD & SE & $\begin{array}{c}95 \% \text { CR } \\
\text { (low tech) }\end{array}$ & $\begin{array}{c}\text { 95\% CR } \\
\text { (high tech) }\end{array}$ \\
\hline Russia & 24 & 2.13 & 159 & 2.18 & 0.797 & 0.163 & 1.79 & 2.46 \\
\hline Hungary & 96 & 1.63 & 389 & 1.26 & 0.932 & 0.095 & 1.44 & 1.81 \\
\hline Romania & 249 & 2.11 & 312 & 2.04 & 0.955 & 0.061 & 1.99 & 2.23 \\
\hline Poland & 117 & 1.64 & 345 & 1.58 & 1.070 & 0.099 & 1.45 & 1.84 \\
\hline Lithuania & 146 & 1.84 & 241 & 1.73 & 0.852 & 0.071 & 1.70 & 1.98 \\
\hline Latvia & 100 & 1.86 & 355 & 1.77 & 0.932 & 0.093 & 1.68 & 2.04 \\
\hline Estonia & 202 & 1.61 & 338 & 1.60 & 0.956 & 0.067 & 1.48 & 1.75 \\
\hline \multicolumn{9}{|l|}{ Czech Republic } \\
\hline Slovakia & 257 & 1.63 & 274 & 1.42 & 1.011 & 0.063 & 1.51 & 1.75 \\
\hline Kazakhstan & 149 & 2.51 & 261 & 2.43 & 0.827 & 0.068 & 2.38 & 2.64 \\
\hline Total & 1340 & 1.86 & 2674 & 1.73 & 0.990 & 0.027 & 1.81 & 1.92 \\
\hline
\end{tabular}


Table 5. Results of the one-way ANOVA analysis for the cultural perception of entrepreneurship in CEE and CIS countries, 2013-2015

\begin{tabular}{|l|r|r|r|r|r|}
\hline & Sum of squares & \multicolumn{1}{|c|}{ df } & Mean square & \multicolumn{1}{c|}{ F } & Sig. \\
\hline Between groups & 116.744 & 8 & 14.593 & 16.260 & 0.000 \\
\hline Within groups & 1194.536 & 1331 & 0.897 & & \\
\hline Total & 1311.281 & 1339 & & & \\
\hline Source: compiled by the author.
\end{tabular}

As expected, in of all the reviewed countries, product innovation is more likely to be introduced by NTBFs than other types of businesses. Typically, the difference is around 0.3, although there are some countries where it is lower (e.g., Slovakia - 0.15, Czech Republic - 0.16) and countries where it is higher (e.g., Latvia 0.41). Therefore, it might be concluded that early entrepreneurs establishing NTBFs in some countries are more effective than others in transforming new technologies into new products and services. In the case of Slovakia, the low difference between NTBFs and the rest of the ventures might be due to the lower share of opportunity-based entrepreneurs in the former group. When it comes to cross-country differences, the most innovative country in terms of products is Poland and the least innovative is Kazakhstan.

There is a lot of evidence that new technology-based ventures internationalize faster. Symeonidou, Bruneel and Autio [Symeonidou et al., 2017] argue that advances in business process outsourcing and open innovation practices have made the choice of technology commercialization and an internationalization strategy increasingly relevant for new technology-based ventures. They also found that new ventures using IP-based commercialization strategies exhibit higher international intensity after foreign market entry than those with hybrid or product-based strategies. Moreover, it was found that NTBFs internationalize faster and more often, and they also do so earlier. As Johnson [Johnson, 2004] finds, while traditional start-ups generally originate as domestic firms and gradually evolve into multinational enterprises, new technology start-ups increasingly begin as already international firms. Therefore, it can be expected that high-tech entrepreneurs will be more international than low-tech entrepreneurs. At the same time, there is a lot of evidence provided by several authors [Ketkar, Acs, 2011; Chou, 2010; Autio, Acs, 2007] that early internationalization intensity is dependent upon cultural, institutional, macroeconomic and socio-demographic variables. Therefore, it can be assumed that there will be substantial differences among countries regarding the intensity of the internationalization of NTBFs.

The results of the one-way ANOVA analysis concerning the propensity to internationalize are presented in Tables 8 and 9. The analysis is based on the variables 'suexport' and 'omexport' (depending on qualifying the respondent as a start-up or owner-manager). Both variables are based on question: What proportion of your customers normally live outside the country? $(1-$ more than $90 \%, 2-76-90 \%, 3-51-75 \%, 4-$

\section{Table 6. Descriptive statistics for product innovation in CEE and CIS countries, 2013-2015}

\begin{tabular}{|c|c|c|c|c|c|c|c|c|}
\hline Countries & $\begin{array}{c}\mathrm{N} \text { (high } \\
\text { tech) }\end{array}$ & Mean (high tech) & N (low tech) & Mean (low tech) & SD & $\overline{\mathrm{SE}}$ & $\begin{array}{c}95 \% \text { CR } \\
\text { (low tech) }\end{array}$ & $\begin{array}{c}\text { 95\% CR } \\
\text { (high tech) }\end{array}$ \\
\hline Russia & 29 & 2.31 & 181 & 2.64 & 0.660 & 0.123 & 2.06 & 2.56 \\
\hline Hungary & 101 & 2.31 & 432 & 2.62 & 0.689 & 0.069 & 2.17 & 2.44 \\
\hline Romania & 281 & 2.26 & 355 & 2.55 & 0.785 & 0.047 & 2.17 & 2.36 \\
\hline Poland & 148 & 2.00 & 421 & 2.24 & 0.660 & 0.054 & 1.89 & 2.11 \\
\hline Lithuania & 165 & 2.24 & 307 & 2.48 & 0.717 & 0.056 & 2.13 & 2.35 \\
\hline Latvia & 122 & 2.11 & 416 & 2.52 & 0.702 & 0.064 & 1.98 & 2.23 \\
\hline Estonia & 257 & 2.14 & 445 & 2.46 & 0.744 & 0.046 & 2.05 & 2.24 \\
\hline Czech Republic & 141 & 2.23 & 262 & 2.39 & 0.701 & 0.059 & 2.11 & 2.34 \\
\hline Slovakia & 292 & 2.26 & 310 & 2.41 & 0.683 & 0.040 & 2.18 & 2.34 \\
\hline Kazakhstan & 194 & 2.37 & 324 & 2.74 & 0.687 & 0.049 & 2.27 & 2.46 \\
\hline Total & 1730 & 2.22 & 3453 & 2.50 & 0.719 & 0.017 & 2.19 & 2.25 \\
\hline
\end{tabular}

\section{Table 7. Results of the one-way ANOVA analysis for product innovation in CEE and CIS countries, 2013-2015}

\begin{tabular}{|l|r|r|r|r|r|}
\hline & Sum of squares & df & Mean square & F & Sig. \\
\hline Between groups & 16.366 & 9 & 1.818 & 3.565 & 0.000 \\
\hline Within groups & 877.285 & 1720 & 0.510 & & \\
\hline Total & 893.651 & 1729 & & & \\
\hline \\
Source: compiled by the author.
\end{tabular}


Table 8. Descriptive statistics for internationalization in CEE and CIS countries, 2013-2015

\begin{tabular}{|c|c|c|c|c|c|c|c|c|}
\hline Countries & $\begin{array}{c}\text { N (high } \\
\text { tech) }\end{array}$ & Mean (high tech) & N (low tech) & Mean (low tech) & SD & SE & $\begin{array}{c}95 \% \text { CR } \\
\text { (low tech) }\end{array}$ & $\begin{array}{c}\text { 95\% CR } \\
\text { (high tech) }\end{array}$ \\
\hline Russia & 26 & 6.58 & 160 & 6.68 & 1.501 & 0.294 & 5.97 & 7.18 \\
\hline Hungary & 98 & 5.51 & 407 & 5.65 & 1.459 & 0.147 & 5.22 & 5.80 \\
\hline Romania & 257 & 5.09 & 317 & 5.52 & 1.818 & 0.113 & 4.86 & 5.31 \\
\hline Poland & 146 & 5.34 & 405 & 5.87 & 1.716 & 0.142 & 5.06 & 5.62 \\
\hline Lithuania & 160 & 5.39 & 288 & 5.44 & 1.602 & 0.127 & 5.14 & 5.64 \\
\hline Latvia & 117 & 5.01 & 383 & 5.51 & 1.827 & 0.169 & 4.67 & 5.34 \\
\hline Estonia & 227 & 5.41 & 380 & 5.51 & 1.925 & 0.128 & 5.16 & 5.67 \\
\hline Czech Republic & 137 & 5.50 & 250 & 5.62 & 1.410 & 0.120 & 5.27 & 5.74 \\
\hline Slovakia & 277 & 5.27 & 296 & 5.49 & 1.446 & 0.087 & 5.10 & 5.45 \\
\hline Kazakhstan & 151 & 5.98 & 227 & 6.37 & 1.426 & 0.116 & 5.75 & 6.21 \\
\hline Total & 1596 & 5.38 & 3113 & 5.70 & 1.672 & 0.042 & 5.30 & 5.47 \\
\hline
\end{tabular}

$26-50 \%, 5-11-25 \%, 6-10 \%$ or less, $7-$ none). Therefore, the higher the score (mean) the lower the internationalization of the venture.

As the data of Tables 8 and 9 show, the differences among the countries are quite substantial. Russia and Kazakhstan had the lowest scores. In Russia, most entrepreneurs (both high-tech and low-tech) never internationalize. Intermediate internationalization is experienced by Hungary, Poland, Lithuania, Estonia, the Czech Republic and Slovakia, and the highest level of internationalization takes place in Romania and Latvia.

The level of early internationalization is due to two major factors: the institutional environment and market size. An analysis of data collected by Cahen, Lahiri and Borini [Cahen et al., 2016] through a questionnaire survey revealed three important barriers to internationalization: external (institutional) barriers, internal (organizational capability) barriers, and human resource barriers. In addition Muralidharan, Pathak, and Laplume [Muralidharan et al., 2015] conclude that early internationalization by new technology ventures may depend upon specific features of their home countries, such as the institutional environment. Those with supportive home country conditions may be more likely to go international in order to gain access to new markets. Moreover, their results indicate that a strong regulatory environment and smaller home market size both support early internationalization. Interaction results also indicate that in the case of a smaller home market, a strong regulatory environment is required for the early internationalization of technology entrepreneurs.

Therefore, the lowest score for Russia might be explained by three factors. First of all, the Russian market is the largest of all analyzed countries as the population is the most numerous. Secondly, the structure of Russian economy is quite specific with a number of very large companies that tend to concentrate smaller companies around them. Lastly, the regulatory environment in Russia does not support internationalization, as follows from the assessment of the entrepreneurial ecosystem taken from GEM National Expert Survey data, 'government policies for support and relevance initiatives' and 'government policies for taxes and bureaucracy' are assessed at the level of 3 on a scale of 1 to 9.

The countries with the highest intensity of NTBF internationalization are Romania and Latvia. Interestingly, those countries also experience also the highest difference between the intensity of internationalization at high-tech and low-tech ventures in the early stages of activity. For other countries, the differences are not as substantial, with the exception of Poland, where the difference is also about 0.5 . Polish low-tech ventures are third lowest in the intensity of internationalization among the reviewed countries, but high-tech ventures hold fourth place.

The last GEM index of entrepreneurial aspirations is the number of jobs that an entrepreneur wants to create in the next five years. There is some evidence that NTBF businesses are growing faster. Almus and Nerlinger [Almus, Nerlinger, 1999] prove that NTBFs achieve on average higher growth rates than young non-innovative firms. They even argue that for the latter the number of jobs destroyed by closures, etc., is greater than the number of new jobs at growing and expanding firms. Moreover, there is evidence that the growth of new businesses is dependent upon country and even local characteristics. According to [North,

\section{Table 9. Results of the one-way ANOVA analysis for internationalization in CEE} and CIS countries, 2013-2015

\begin{tabular}{|l|r|r|r|r|r|}
\hline & Sum of squares & \multicolumn{1}{|c|}{ df } & Mean square & \multicolumn{1}{|c|}{ F } & \multicolumn{1}{c|}{ Sig. } \\
\hline Between groups & 137.348 & 9 & 15.261 & 5.602 & 0.000 \\
\hline Within groups & 4320.207 & 1586 & 2.724 & & \\
\hline Total & 4457.556 & 1595 & & & \\
\hline Source: compiled by the author.
\end{tabular}


Table 10. Descriptive statistics for firm growth in CEE and CIS countries, 2013-2015

\begin{tabular}{|c|c|c|c|c|c|c|c|c|}
\hline Countries & $\begin{array}{c}\mathrm{N} \text { (high } \\
\text { tech) }\end{array}$ & Mean (high tech) & N (low tech) & Mean (low tech) & SD & SE & $\begin{array}{c}95 \% \text { CR } \\
\text { (low tech) }\end{array}$ & $\begin{array}{c}\text { 95\% CR } \\
\text { (high tech) }\end{array}$ \\
\hline Russia & 28 & 5.64 & 180 & 5.61 & 8.786 & 1.660 & 2.24 & 9.05 \\
\hline Hungary & 99 & 17.92 & 421 & 9.04 & 48.050 & 4.829 & 8.34 & 27.50 \\
\hline Romania & 279 & 13.46 & 350 & 14.85 & 33.942 & 2.032 & 9.46 & 17.46 \\
\hline Poland & 146 & 9.26 & 408 & 7.57 & 21.619 & 1.789 & 5.72 & 12.80 \\
\hline Lithuania & 163 & 8.69 & 303 & 7.82 & 26.239 & 2.055 & 4.63 & 12.75 \\
\hline Latvia & 120 & 13.02 & 412 & 11.28 & 34.632 & 3.161 & 6.76 & 19.28 \\
\hline Estonia & 254 & 8.23 & 441 & 5.83 & 25.011 & 1.569 & 5.14 & 11.32 \\
\hline Czech Republic & 141 & 8.59 & 261 & 7.70 & 22.907 & 1.929 & 4.77 & 12.40 \\
\hline Slovakia & 288 & 14.59 & 306 & 8.68 & 41.275 & 2.432 & 9.80 & 19.37 \\
\hline Kazakhstan & 194 & 17.48 & 321 & 7.50 & 49.438 & 3.549 & 10.48 & 24.48 \\
\hline Total & 1712 & 12.21 & 3403 & 8.75 & 34.901 & 0.844 & 10.56 & 13.87 \\
\hline
\end{tabular}

Smallbone, 1995; Storey, 1994] there is a strong correlation between local characteristics and firm growth. In terms of country-level influence the most frequently mentioned factors are wage and salary rates, which are interpreted as a cost factor preventing the hire of new employees and therefore have a negative influence on growth [Rees, Stafford, 1986; Oakey, 1994]. Taking all of the above into consideration, both the positive difference between NTBFs and low-tech firms and the variation among countries in terms of job creation should be observed. The results of the one-way ANOVA analysis are presented in Tables 10 and 11. The variable taken into consideration is the increase in the number of jobs (TEAJOBGR). Outliers of above 300 new jobs have been excluded from the analysis as being decidely too optimistic or abstract answers. They were replaced with the value of 300 .

The analysis yielded some surprising results. First of all, as expected, the projected job creation is higher for NTBFs than for the rest of early entrepreneurs. There is one exception, Romania, where high-tech entrepreneurs declare lower anticipated job creation than their low-tech counterparts. That might be caused by the very high share of NTBFs among TEA entrepreneurs, which might limit their growth. Secondly, the differences among countries are substantial. Russian early entrepreneurs had the lowest projections for growth with no substantial differences between high-tech and low-tech ventures. The highest growth aspirations were expressed by NTBF owners from Hungary and Kazakhstan. In those two cases the difference between high-tech entrepreneurs and the remaining enterprises was the most substantial. The first group declared on average the willingness to create two times as many jobs as the latter. To further analyze the growth patterns of NTBFs and other companies, one must focus on rapidly growing businesses, where the owners hope to create at least 19 jobs over next five years and increase employment by at least $50 \%$ (Figure 4 ).

The analysis of rapidly growing NTBFs partially confirms the analysis of average job creation. Again Hungary stands out as a country with very high growth potential for high-tech entrepreneurs. Two out of five declare that they will create at least 19 new jobs. Again, Romania is the country (along with the Czech Republic) with the smallest difference between high-tech and low-tech entrepreneurs in terms of growth potential.

When analyzing those results, two factors must be taken into consideration: the pattern of NTBF growth over time and the external environment. Grilli [Grilli, 2014] draws attention to a number of country-level determinants of NTBF growth, for instance, the social and regulatory burdens arising from (honest) firm failure, the local nature of the venture capital industry, the "halo and certification" effect of direct public subsidies and grants given to NTBFs. Furthermore, as Rizzo, Nicolli and Ramaciotti [Rizzo et al., 2013] prove in their research, the process of NTBF growth is even less linear than the process of non-technologybased venture growth. Therefore, both factors are to be considered when considering the impact of a specific environment on NTBF growth and, secondly, when planning activities aimed at supporting the growth of NTBFs.

\section{Conclusions - the capacity of NTBFs to contribute to economic and social development}

The present study provides a diverse and complex picture of the capacity of NTBFs to contribute to economic and social growth. To conclude, I will highlight the most important results. First of all, there is great variety in the shares of NTBFs in the TEA sample across countries, which range from $13.8 \%$ (Russia) to $48.5 \%$

Table 11. Results of the one-way ANOVA analysis for firm growth in CEE and CIS countries, 2013-2015

\begin{tabular}{|l|r|r|r|r|r|}
\hline & Sum of squares & \multicolumn{1}{|c|}{ df } & Mean square & F & Sig. \\
\hline Between groups & 21123.384 & 9 & 2347.043 & 1.936 & 0.043 \\
\hline Within groups & 2063012.942 & 1702 & 1212.111 & & \\
\hline Total & 2084136.327 & 1711 & & & \\
\hline Source: compiled by the author.
\end{tabular}




\section{Figure 4. The share of rapidly growing ventures in CEE and CIS countries, 2013-2015}

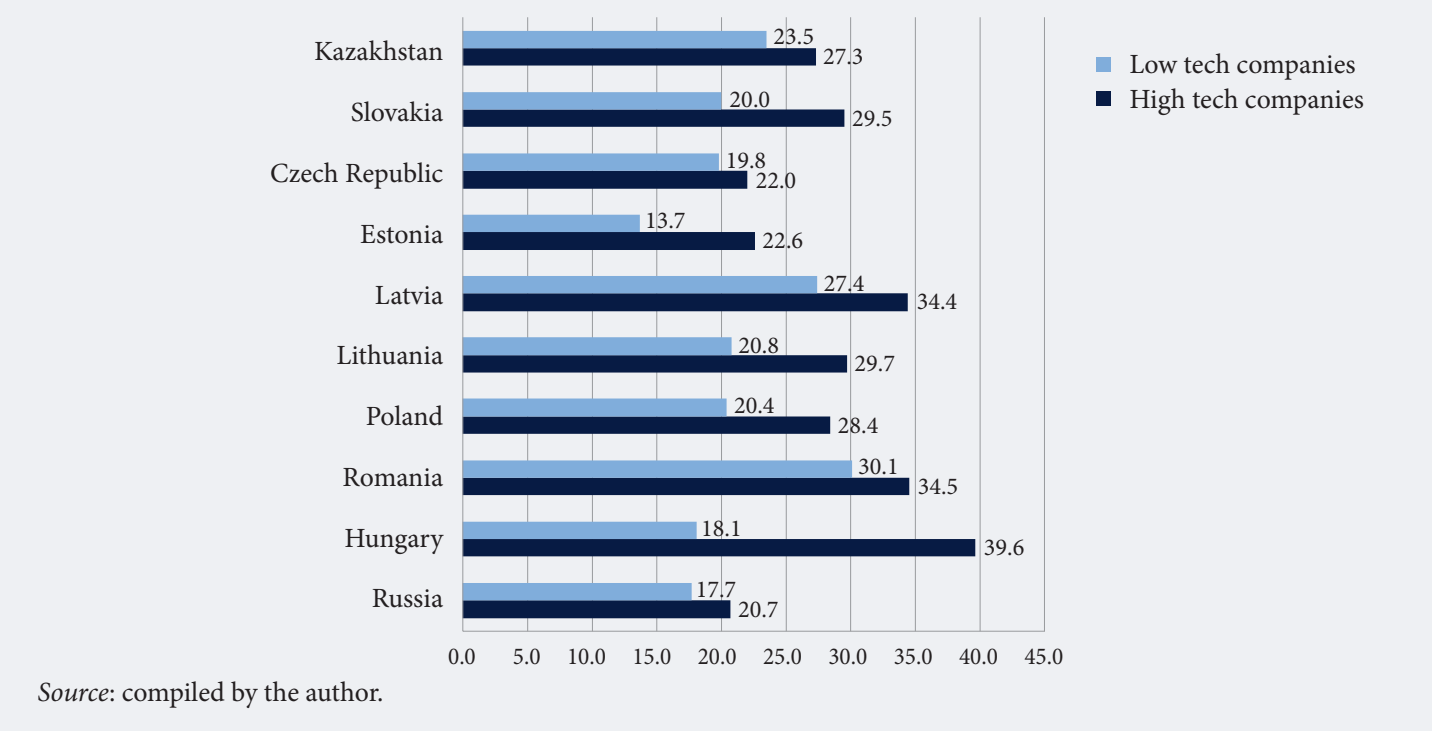

(Slovakia). When considered together with the level of TEA, the effect is doubled and consequently the share of early stage (up to 3.5 years of activity) NTBF owners ranges from $0.7 \%$ (Russia) to almost 5\% (Slovakia, Romania and Kazakhstan). That difference alone might have a serious impact on the capacity of hightech new ventures to affect economic and social development. Moreover, when combined with the growth potential of NTBFs, the impact might even be magnified, as declarations concerning future employment also significantly differ. For instance, if the growth projections for the three countries with the highest shares of high-tech venture owners in society (Slovakia, Romania, and Kazakhstan) are met, then NTBFs would create jobs for about $60-70 \%$ of population over next five years (compared to about $4 \%$ in Russia). This, of course, is not realistic because such projections are highly overconfident [Navis, Ozbek, 2017; Koellinger et al., 2007] and there is also high potential for failure among NTBFs. However, the combination of the number of high-tech ventures and their growth aspirations (even if they are only declared) point to huge differences in the capacity for job creation among the various CEE and CIS countries.

Another finding concerns the differences in the internationalization of NTBFs between the analyzed countries. Clearly willingness to internationalize is dependent upon two factors: the institutional regulatory environment and the size of the domestic market. Therefore, entrepreneurs in big CIS countries like Russia and Kazakhstan are less inclined to internationalize due to the opportunities available on the domestic market. Moreover, in light of research carried out by [Coeurderoy, Murray, 2008], it has to be noted that NTBFs embarking on a strategy of rapid internationalization choose foreign markets that minimize transaction costs and the related risks of failure. Young entrepreneurial firms choose to enter foreign markets that offer better regulatory protection for their intellectual property. This decision is moderated by the home country's regulatory regime.

Although a sample of ten countries is too small to draw definite conclusions, some patterns are discernible. For instance, countries with high TEA rates also have a high share of opportunity-based entrepreneurship. This, for example, is clearly visible in Baltic countries. At the same time, there are some expectations that were contradicted by our data. For instance, opportunity-based entrepreneurship should result in higher product innovation, but that effect was not observed. Countries with the highest share of opportunity entrepreneurs (Czech Republic, Lithuania, Latvia, and Estonia) are only average in product innovation. Another missing relationship is the one expected between the individual self-assessment and/or cultural perception of entrepreneurship and the TEA rate and the share of opportunity-based entrepreneurship. In CIS countries, the self-assessment by early entrepreneurs was very high, but it does not result in high TEA or opportunity-based entrepreneurship. On the other hand, countries with a low cultural perception of entrepreneurship (Poland, Hungary, Slovakia, and Estonia) enjoy rather satisfactory TEA rates.

The study contributes to forecasting the future effects of NTBFs on the economies of CEE and CIS countries, however, there are some limitations. First of all, the sample was not chosen specifically for this study. Even though the Global Entrepreneurship Monitor is robust, it captures only ventures using new technologies, therefore we cannot be sure that those are actually high technologies. Moreover, the assessment of the novelty of a given technology was based on an assessment by the entrepreneurs themselves, so we might expect some bias in that regard. Secondly, the data on aspirations for growth, internationalization, and innovation are simply the projections of the entrepreneurs, so again, some bias is expected. Finally, the relationships presented in the paper might be strongly influenced by external factors and sample pooling might even magnify that impact. Taking all these limitations into consideration, the patterns presented in the paper remain significant for forecasting this future socioeconomic development of the studied countries. 


\section{References}

Aidis R., Estrin S., Mickiewicz T. (2008) Institutions and entrepreneurship development in Russia: A comparative perspective. Journal of Business Venturing, vol. 23, no 6, pp. 656-672.

Aidis R., Estrin S., Mickiewicz T. (2012) Size matters: Entrepreneurial entry and government. Small Business Economics, vol. 39, no 1, pp. 119-139.

Ajzen I. (1991) The theory of planned behaviour. Organizational Behavior \& Human Decision Processes, vol. 50, no 2, pp. 179-211.

Ajzen I. (2011) The theory of planned behavior: Reactions and reflections. Psychology \& Health, vol. 26, no 9, pp. 1113-1127.

Almus M., Nerlinger E.A. (1999) Growth of New Technology-Based Firms: Which Factors Matter? Small Business Economics, vol. 13, no 2, pp. 141-154.

Autio E., Acs Z. (2007) Individual and country-level determinants of growth aspiration in new ventures. Paper presented at the Babson Conference on Enterpreneurship Research, Madrid, June 6-9, 2007.

Cahen F.R., Lahiri S., Borini F.M. (2016) Managerial perceptions of barriers to internationalization: An examination of Brazil's new technology-based firms. Journal of Business Research, vol. 69, no 6, pp. 1973-1979.

Campos E.B., Somoza M.L., Salmador M.P. (2011) CoPs \& Organizational Identity. Handbook of research on communities of practice for organizational management and networking: Methodologies for competitive advantage (eds. O.R. Hernaez, E.B. Campos), Hershey, PA: IGI Global, pp. 308-336.

Cannone G., Pisoni A., Onetti A. (2014) Born global companies founded by young entrepreneurs. A multiple case study. International Journal of Entrepreneurship \& Innovation Management, vol. 18, no 2/3, pp. 210-232.

Chou L. (2010) Cultural ecology: An environmental factor of born globals' success. Review of Business Research, vol. 10, pp. 108-114.

Coeurderoy R., Murray G. (2008) Regulatory environments and the location decision: Evidence from the early foreign market entries of new-technology-based firms. Journal of International Business Studies, vol. 39, no 4, pp. 670-687.

Estrin S., Mickiewicz T., Stephan U. (2013) Entrepreneurship, social capital, and institutions: Social and commercial entrepreneurship across nations. Entrepreneurship Theory and Practice, vol. 37, no 3, pp. 479-504.

Grilli L. (2014) High-Tech Entrepreneurship in Europe: A Heuristic Firm Growth Model and Three "(Un-)easy Pieces" for Policy-Making. Industry \& Innovation, vol. 21, no 4, pp. 267-284.

Groen A.J., Wakkee I.A.M., De Weerd-Nederhof P.C. (2008) Managing Tensions in a High-tech Start-up. International Small Business Journal, vol. 26, no 1, pp. 57-81.

Gruber M., Henkel J. (2008) New ventures based on open innovation - An empirical analysis of start-up firms in embedded Linux. International Journal of Technology Management, vol. 33, no 4, pp. 356-372.

Gupta A.K., Wilemon D.L. (1990) Accelerating the Development of Technology-Based New Products. California Management Review, vol. 32, no 2, pp. 24-44.

Johnson J.E. (2004) Factors Influencing the Early Internationalization of High Technology Start-ups: US and UK Evidence. Journal of International Entrepreneurship, vol. 2, no 1/2, pp. 139-154.

Kelley D., Singer S., Herrington M. (2016) Global Entrepreneurship Monitor 2015/16 Global Report, London: GERA.

Ketkar S., Acs Z. (2011) Cultural burdens and institutional blessings: Internationalization by SMEs from emerging countries. Paper presented at 2011 Academy of Management Annual Meeting, San Antonio.

Koellinger Ph., Minniti M., Schade Ch. (2007) "I think I can, I think I can": Overconfidence and entrepreneurial behaviour. Journal of Economic Psychology, vol. 28, no 4, pp. 502-527.

Marlow S., McAdam M. (2012) Analyzing the Influence of Gender Upon High-Technology Venturing Within the Context of Business Incubation. Entrepreneurship: Theory \& Practice, vol. 36, no 4, pp. 655-676.

Mayer H. (2008) Segmentation and Segregation Patterns of Women-Owned High-Tech Firms in Four Metropolitan Regions in the United States. Regional Studies, vol. 42, no 10, pp. 1357-1383.

Muralidharan E.K., Pathak S., Laplume A.O. (2015) Internationalization by technology entrepreneurs: A multilevel study. Academy of Management Annual Meeting Proceedings. Режим доступа http://proceedings.aom.org/ content/2015/1/17571.short?rss=1, дата обращения 14.03.2017.

Navis Ch., Ozbek O.V. (2017) Why Context Matters: Overconfidence, Narcissism, and the Role of Objective Uncertainty in Entrepreneurship. Academy of Management Review, vol. 42, no 1, pp. 148-153.

North D., Smallbone D. (1993) Employment Generation and Small Business Growth in Different Geographical Environments. Paper presented at the 16th ,National Small Firms Policy and Research Conference, Nottingham, 17-19 November.

Oakey R.P. (1994) New Technology-based Firms in the 1990s, London: SAGE Publications Ltd.

Ouimet P., Zarutskie R. (2014) Who works for startups? The relation between firm age, employee age, and growth. Journal of Financial Economics, vol. 112, no 3, pp. 386-407.

Rees J., Stafford H. (1986) Theories of Regional Growth and Industrial Location: Their Relevance for understanding High-Technology Complexes. Technology, Regions, and Policy (ed. J. Rees), Totowa: Rowman and Littlefield, pp. 23-50.

Reynolds P.D. (2017) When is a Firm Born? Alternative Criteria and Consequences. Business Economics (forthcoming).

Rizzo U., Nicolli F., Ramaciotti L. (2013) The development process of new technology-based firms. International Journal of Entrepreneurship \& Innovation Management, vol. 17, no 4, pp. 352-369.

Storey D.J. (1994) Understanding the Small Business Sector, London: International Thomson Business Press.

Symeonidou N., Bruneel J., Autio E. (2017) Commercialization strategy and internationalization outcomes in technology-based new ventures. Journal of Business Venturing, vol. 32, no 3, pp. 302-317.

Tan J. (2008) Breaking the "Bamboo Curtain" and the "Glass Ceiling": The Experience of Women Entrepreneurs in High-Tech Industries in an Emerging Market. Journal of Business Ethics, vol. 80, no 3, pp. 547-564. 


\title{
Stakeholder Relationships in the Framework of R\&D-based Startups: Evidence from Turkey
}

\author{
Elif Kalayci \\ Assistant Professor, Department of Economics, elif.kalayci@atilim.edu.tr \\ Atilim University, Kızılcaşar Mahallesi, İncek / Ankara, Turkey.
}

\begin{abstract}
$\mathrm{I}$

$\mathrm{t}$ is widely acknowledged that R\&D- based start-ups play a significant role in the economic growth of many countries. However, founding such an enterprise is a risky endeavor, one that requires a balance between the technological search process and business capabilities. Most of the time these varied skills are found among several different people. The task becomes more difficult for recent engineering school graduates who are neither scientists nor business people. Therefore, it is critical for these new techno-entrepreneurs to conscientiously work on building relationships with stakeholders through whom they might access scientific knowledge on one hand and commercial knowledge on the other.

The paper explores the process of building relationships with stakeholders based on evidence from Turkish companies. It begins with a review of the literature, presenting the different theories concerning relationships with stakeholders as far as entrepreneurship is concerned. Then, it presents the methodology, coding and analysis of in-depth interviews with the founders of R\&D-based start-ups. The case profiles are considered with a focus on the following issues: the counterbalancing of stakeholder power, learning by the entrepreneur as a by-product of interactions with stakeholders, and the earning of

a reputation through ethical and passionate business practices. Building upon these preliminary findings, the author draws three main propositions that could be the subject of further research.

The main finding of this paper is that there are two opposing forces affecting the development of an R\&D -based start-up- challenger and supporter stakeholders. However, a stakeholder who was once a supporter could turn into a challenger or vice versa. The entrepreneur could benefit from the counterbalancing effect of these forces. Two major stakeholder groups emerged at the initial stage of the business: the family members and the state's grant-monitoring officers. Then, the ethical and passionate conduct of business by these start-ups could become a factor drawing third parties in, to become stakeholders of these start-ups. The nature and impact of these relationships should be researched further. Such an analysis allows one to understand how R\&D-based startups are established and what kind of problems they face when turning (hopefully) into large corporations. On such a basis, this could help governments develop more suitable support programs that would benefit and expand the opportunities available to the founders of new R\&Dbased firms.
\end{abstract}

Keywords: technological entrepreneurship; stakeholder relationships; challenger stakeholder; supporter stakeholder; causation logic; effectuation logic; R\&D-based startups; Turkey.
Citation: Kalayci E. (2017) Stakeholder Relationships in the Framework of R\&D-based Startups: Evidence from Turkey. Foresight and STI Governance, vol. 11, no 3, pp. 61-70. DOI: 10.17323/2500-2597.2017.3.61.70 
I n many countries, governments consider R\&D-based start-ups significant contributors to economic growth [Scottish Executive, 2001; OECD, 2003]. Given this role, one must analyze the experiences of these entities in order to understand how they are established and the problems they face as they turn (hopefully) into large corporations. Such an analysis could help governments develop more suitable support programs and open opportunities for new R\&D-based firms. Furthermore, these firms intend to launch R\&D-based products on the market and therefore face uncertainty in two distinct areas: one is research and development [Julien, 1995] and the other is commercialization [Gans, Stern, 2003].

In such a precarious environment, these start-ups need all the support they can get. Stakeholders are critical at this point because they are the providers of such resources. Thus, the founders of an R\&D-based start-up need to make deliberate efforts at turning third parties into stakeholders [Sarasvathy, Venkatamaran, 2011]. Sarasvathy and Venkatamaran assert: 'Almost the entirety of social network research takes networks mostly as a given and outside the control of human action' [Sarasvathy, Venkatamaran, 2011, p. 126]. Yet as negotiation research has demonstrated, it is not easy for people to reach mutually beneficial agreements [Bazerman, Neale, 1992]. Building a cohesive and committed relationship relies on an endogenous process of continuous interactions between the parties [Lawler, Yoon, 1996; Thompson et al., 2000].

Turkey as a developing country serves as an interesting case to illustrate the experiences of R\&D-based startups. Since 2010, the Turkish government has provided an increasing amount of seed funding to university graduates who intend to establish a start-up with the goal of developing a high-tech, R\&D-based product and commercializing it [MSIT, 2014]. The name of this program is 'Techno-Entrepreneurship'. However, to the best of our knowledge, as of 2016, no qualitative research on the experiences of these techno-entrepreneurs has been published.

The topic of the present research concerns how entrepreneurs build relationships with third parties as the potential stakeholders of an R\&D-based start-up. In section one; we begin with a literature review, presenting the different theories on stakeholder relationships as far as entrepreneurship is concerned. Section two presents our methodology, coding, and analysis based on the justified use of a qualitative approach. Section three contains our case profiles, while section four provides an analysis of the following themes: the counterbalancing of stakeholder power, learning by the entrepreneur as a by-product of stakeholder interactions, and earning one's reputation through ethical and passionate business practices. Building upon these preliminary findings, section five, draws three main hypotheses that could be the subject of further research, and section six presents the article's conclusions.

\section{Literature Review}

The establishment of an R\&D-based start-up is a risky endeavor that requires a balance between the technological search process and business capabilities. Not only must an entrepreneur focus on R\&D activities to create a feasible product, but he/she must also create a commercially viable and sustainable organization. Most of the time, R\&D capabilities and business capabilities are found among a variety of different individuals [Daniels, Hofer, 1993]. The task becomes more difficult for recent engineering graduates who are neither scientists nor business people. Therefore, it is critical for these new techno-entrepreneurs (those who set up a business based on R\&D) to develop strong relationships with stakeholders through which they can access both scientific knowledge and commercial know-how.

The resource dependence theory states that an organization is dependent upon accessible resources in its environment for its survival [Pfeffer, Salancık, 1978]. The extent of this dependence is directly proportional to the significance of a particular resource for the organization. Investors, those who control the resources, determine the subject of investment [Frooman, 1999; Pfeffer, Salancik, 1978]. In the case of R\&D-based start-ups, scientific and commercial knowledge are the critical resources they need. Thus, the owners of such resources are the people that the entrepreneur must reach and involve in the initial stages of founding an enterprise.

Stemming partly from the resource dependence theory, the stakeholder theory defines stakeholders as "any group or individual who can affect or is affected by the achievement of an organization's objectives" [Freeman, 1984, p. 46]. The stakeholder theory states that the salience of stakeholders depends on three main concepts power, legitimacy, and urgency. The power of a stakeholder emerges from the dependence of a firm on stakeholders for resources [Mitchell et al., 1997]. As the dependence of the organization on the resource increases, the power of the stakeholder on the organization also grows [Frooman, 1999]. The legitimacy of a stakeholder has to do with the negotiating relationship between the stakeholder and the start-up's managers. Those who have a claim on the start-up have legitimacy. Most of the time, power is assumed to be coupled with legitimacy, yet, not every legitimate stakeholder has power or influence such as the case of 'minority shareholders. The opposite also holds, illegitimate stakeholders could have great power as in the case of 'corporate raiders'. Urgency is defined as "the degree to which stakeholder claims call for immediate attention" [Mitchell et al., 1997, p. 867]. When legitimacy and urgency coincide, the need for being heard by decision-makers increases. When power and urgency are simultaneously present, the stakeholder takes action. When power, legitimacy and urgency all coincide, both parties acknowledge the situation and take action in a reciprocal manner.

As these theories were mainly conceptualized for existing firms, not start-ups, they fall short of identifying who should be the stakeholders of start-ups. The theory of effectuation proposed by Sarasvathy [Sarasvathy, 2001] was developed to explain entrepreneurship, but lacks an explanation regarding the relationships with stakeholders. There is a void in the literature on how stakeholder relationships are formed at the time of establishing a start-up, particularly when the start-up actively pursues R\&D.

Steyaert [Steyaert, 1997] claims that in order to comprehend entrepreneurship as a process, one has to study 'stories' of start-ups because they are context-dependent. The local conditions exert forces that shape the behavior of entrepreneurs. Thus, in this work, we chose to take a qualitative approach and collect local stories of R\&D-based start-ups in Ankara, Turkey. 
When a firm is in the process of being created, stakeholder relationships are already forming. As a result, entrepreneurs choose the stakeholders with whom they want to build such connections. The relationships they would invest in would be those with investors who would help them realize their start-up [Sarasvathy, 2001]. For instance, a recent engineering graduate, who wants to turn his class project into a commercial product most likely knows what knowledge he lacks but does not know where to find sources of knowledge and support. Furthermore, if he approaches a professor, will the professor spare his precious time on this project? Assuming he somehow comes up with a technologically feasible prototype, who should he ask for help when it is time to market the product, set up an enterprise, and finance the venture?

\section{Methodology}

Evers et al. [Evers et al., 2012, p. 55] note: "the CEO/founder entrepreneur is the key decision maker for driving the companies forward from inception and leveraging their stakeholder relationships". Moving from this finding, in this study we conducted in-depth interviews with the founders of R\&D-based start-ups. In order to reach R\&D-based start-ups, we used a list of start-ups that participated in a project fair organized by the Ankara Development Agency in 2012. A common feature of these start-ups is that they were all founded in 2011 upon receiving seed capital of $100.000 \mathrm{TL}^{1}$ from the Turkish Ministry of Science, Industry and Technology on the condition that they engage in $\mathrm{R} \& \mathrm{D}$. We considered only those start-ups in the manufacturing sector so that we could have some common ground in the sample. Thus, we used criterion sampling [Patton, 2002]. The criterion was that the manufacturing sector start-ups that attended the project fair of the Ankara Development Agency in 2012. The attendees of the project fair were announced on a list containing the names and contact details of the entrepreneurs, the industry and some information about the product they intended to promote at the fair. One downside of using such a list is that not all entrepreneurs who received the techno-entrepreneurship grant from the Ministry of Science, Industry and Technology attended this fair. Therefore, there might be a bias towards those who were able to successfully develop a prototype in the year following the receipt of this grant. However, since there was no other way to obtain the contact information of these techno-entrepreneurs, we had to deal with what information was publicly available. Between the months of June and August 2015, we contacted 12 different entrepreneurs in the manufacturing sector to conduct in-depth interviews. Since our aim was to explore the period of developing stakeholder relationships, and to avoid generalizing the findings, a small number of cases could be used to derive rich and meaningful information [Coviello, Jones, 2004]. According to Patton [Patton, 2002, p. 245]: "The validity, meaningfulness, insights generated from a qualitative inquiry have to do more with the information richness or the cases selected and the observational (analytical) capabilities of the researcher than with the sample size". Thus, we picked three cases for this study as they were the most rich and illustrative.

\section{Coding and Analysis}

Our work is built upon the principles of grounded theory, which was developed using inductive methods based on information gathered over the course of social research [Strauss, Curbin, 1990]. According to this theory, the research questions of the study are considered preliminary and are expected to change as findings are uncovered. Given that before conducting the research, the researcher observes only the outcome of what has taken place, he or she does not know how the processes unfolded. Therefore, the research questions take shape as the researcher learns the whole story from the perspective of the study subjects [Maxwell, 1996]. A guiding principle of grounded theory is constant comparison, which means the components of the theory are developed and refined throughout the study. As concepts emerge, they are compared with new data and refined until saturation takes place. In this study, the data was collected using semi-structured and open-ended interviews with founding entrepreneurs [Eriksson, Kovalainen, 2008]. The interviews were conducted at the interviewee's premises and yielded visual data on the work environment of the entrepreneurs. Voice recordings were transcribed as soon as possible after the interviews and reviewed for any errors by the researcher. Coding was performed using QDAMiner Lite software.

\section{Trustworthiness}

After each case was written, they were sent to the entrepreneurs or founding partners, who reviewed them for accuracy. In one case, the entrepreneur provided some supplemental information. All three approved our unbiased approach. To provide investigator triangulation, two evaluators reviewed the material in each case. This approach allowed us to compare and contrast independent judgements and interpretations concerning the content of the material.

\section{Case Profiles}

Firm A was founded by a chemistry major from a private university in Ankara in 2012. This was the founder's second start-up. In 2011, the founder received the techno-entrepreneurship grant and set up a lab in his family's summer house in the Kazan district outside of Ankara. After working for three months with a single employee, a university classmate, they were able to develop the prototype. Yet, they could not complete all the tests required for the project. One of the tests was not applicable to the materials they were using. For another test, there was not enough time to apply to the Turkish Standards Institute (TSI), so instead of TSI testing, the entrepreneur developed his own test for the prototype with the help of a friend. However, the academic monitor appointed by the ministry required word-for-word compliance with the project guidelines and finding that a test was missing, reported this violation to the ministry. As such, the activities of the firm were suspended. In 2012, after meeting his employee's boyfriend at a barbeque party and learning that his area of PhD research was laser technology, he asked if it was possible to develop a new laser hair removal device. Upon receiving 
an enthusiastic 'yes', the founder and his new partner began working on this project, applied for the technoentrepreneurship grant and received it one more time. The founder had high hopes for this product because the founder's aunt was running a beauty parlor and the founder knew laser hair removal devices on the market often burned the skin along with the hair, so a device that would not harm the user's complexion had a high chance of success on the market. While developing the laser hair removal device, the founder and his partner published two articles in a medical journal and received one patent. However, they ran out of cash and applied for a subsidy from the Scientific and Research Council of Turkey (TUBITAK) in 2013. Although their subsidy was approved in March, the money was delayed for eight months and did not arrive until September. Meanwhile the founder asked for help from his parents and they mortgaged their flat, which financed the firm in the interim period. Two days before the flat was to be sold, the cash they expected from TUBITAK arrived, which saved the apartment.

As of July 2015, the firm had nine employees, held a patent with two more applications pending. The firm had received support from an angel investor in return for $30 \%$ of the firm's shares. With the new investment, the firm's current goal is to launch the product on the domestic and two foreign markets.

Firm B has two partners, E.Ç and H.K. Both majored in mechanical engineering and met in 2003 when they were working on the design and development of a solar-powered car. By September 2010, they had applied for the techno-entrepreneurship grant for two different business ideas and had also accumulated work experience throughout this period. Having won R\&D grants for both business ideas, they first started out with two firms aimed at the same markets, municipalities that in the end were not prepared to buy their products. They therefore halted both projects and set up a design-based manufacturing firm as they saw a market in this area. Previously one of the partners, H.K., had worked with an Austrian firm and was still in contact with it. Upon a request from that firm, they created their first custom-made chandelier, which was installed on a U.S.-based intercontinental cruise line. The cruise-line, which was a client of the Austrian firm, was delighted with the product. This encouraged more orders and given that they only had a 44-square-meter office at a technopark, the founders soon felt they needed a larger space to begin manufacturing work in addition to design. In addition to the office, they decided to rent a four story-building with 800 square meters of closed space and 100 square meters of open area in the Organized Industrial Region in Ankara (OSTIM) ${ }^{2}$. On the ground floor manufacturing took place, the first floor hosted the office space, mechatronics works, and a dormitory. The basement and the second floor were allocated for storage, assembly lines and testing areas. E.C. explained the need for a dormitory: 'We get exhausted from work... Lose track of time... Need to look at the calendar to know which day it is, but I certainly know that in seven days this chandelier needs to be manufactured, assembled, installed, shipped, etc. ... For the past year, I have literally lived in this place.'

All of their sales were exported and they have not sold a single product on the domestic market. Their products are unique because they are custom-designed and manufactured per the wishes of the customer. They have local and international suppliers including those from: Egypt, Slovakia, the U.S., China, and Austria. In order to decide whether to work with an international supplier or not, they fly to the country, visit the firm, see the products and then make their decision. Thus, when H.K. leaves home to check out suppliers, he 'could leave for one or two weeks with a single piece of luggage, but may end up spending one to two months with the same luggage.' As of July 2015, the firm had 15 employees. The financial value of the project they have on hand, is the highest it has ever been in the company's entire history.

Firm $\mathrm{C}$ was founded by an Electricity and Electronics Engineering major from a private university in Ankara. In 2010, while she was a graduate student working on her thesis project under the guidance of a professor, she developed a unique product. At the time, this product was not being produced in Turkey. She developed the design and wrote an academic paper on it. This paper was submitted to an academic conference in Turkey, where it received the award for best student paper. After applying for the techno-entrepreneurship grant and receiving what she called 'free money', the firm was founded in April 2011 despite strong objections from her father. Her father, a civil servant turned entrepreneur disapproved of her efforts at creating a start-up, declaring 'you should be a civil servant, entrepreneurship is unbearably difficult, and you will have to sacrifice too much. If you take this grant, I will not talk to you'. Her mother also sided with her father. However, her older brother supported her, so she started her own venture and her father stopped talking to her. Initially she had no partners but her professor, who was the advisor for her thesis project and supported her whole-heartedly. The rector of the university also was a professor of hers, and upon hearing of her success in receiving seed funding (among all the grant receivers, she was the only grant recipient from her university), the rector offered her a free office with all utilities paid. By the time she began working, she had three former classmates looking for employment, so she offered them jobs. Together, they developed different versions of the first product. When it was time to find customers, they literally started knocking on doors around campus to tell potential customers that 'they were students who had created a product, would they be interested in buying it?' As they found customers and began manufacturing, they also began earning good profits. After deducting expenses and taxes, the entrepreneur distributed all earnings equally among her employees, as if they were her partners. However, one of her employees left for military service while another decided to become a civil servant and quit the company. In the meantime, the entrepreneur finished her master's degree studies and began a PhD program, both of which were focused on electronics. Her professor stood with her at all times. However, the university's support was not as reliable. There were a couple of times that the university administration asked her to leave and she started looking for a new place. The university administration either retreated or asked her to change her office to another building, which cost her as each time she moved, she had to change her legal address. As a result of these changes, she bought an office building to be safe in case the university administration decided they could no longer host her business. Yet, in her office at the university, with her remaining employee, she worked very hard (i.e., there were times when they worked for 20 hours a day). Together they acquired increasing amounts

${ }^{2}$ OSTİM is an organized industrial region in Ankara. Established in 1967, OSTİM accomodates 5,200 SMEs employing 60,000 people within an area of 5 million square meters ( http://www.ostim.org.tr/p/5244). 
of business and accumulated sound references. However, after a year or so, to her surprise, the entrepreneur found out that this employee had been doing business behind her back. This incident caused the entrepreneur so much stress that she developed diabetes. After parting ways with that employee and her dealing with health issues, she faced pressure from her father once again, who said: 'I will not die in peace before I see you working as a civil servant. Thus, she decided to switch career paths and found a teaching job at a state university, but could not stand the idea of closing down her firm. As a means of truce with her family, she took on the teaching job as a civil servant and made her mother a partner since she could not both own a firm and work as a civil servant at the same time. By that time, she had developed sound enough relationships with a manufacturing firm that took over her firm's manufacturing operations, which decreased her dependence on employees. In return, she began undertaking R\&D projects for that firm. She started to work part-time at the firm along with her teaching job. As of 2015, with one pending and one new patent application under review, the firm was a partnership with the entrepreneur in charge of R\&D. Manufacturing operations were outsourced to a 50-year-old local firm. As of July 2015, the firm had developed 150 different products and accumulated sound references through which new customers were coming to the firm.

\section{Analysis \\ Entrepreneurs benefit from the counterbalancing power of the stakeholders}

The 'story' of each start-up is unique but a common point emerging in all is the development of a start-up amidst, crudely speaking, two opposing forces. Tables 1-3 present a chronological summary of the milestones as these opposing forces take action. The aim here is to see when each stakeholder emerges in the timeline and the events defining a stakeholder's relationship with the entrepreneur. The left-hand column contains problematic or "challenger" stakeholders and the right-hand column contains "supporter" stakeholders. The numbers follow the chronological order of events that unfolded with each stakeholder. For each case, three periods are detected as indicated by period numbers in the column on the far left. A significant event marks the end of a period and the beginning of a new one.

On one hand, there are the challenger stakeholders and on the other, there are those who provide support. In each case, the challenger stakeholder is a different one, but to alleviate the pressure from the challenger stakeholders, the entrepreneur relies upon support from other stakeholders. For example, the entrepreneur in Case $\mathrm{C}$ had to face her father's strong opposition after receiving the seed funding. In this first instance of pressure from her father, she relies on three other stakeholders: her professor, her older brother and her alma mater's rector. Her professor supported her by saying: "My father did not allow me to start my own business. Had I given it a try, I may have been in a very different place. I am a professor now, fine, but you go ahead and try. If you fail, you fail, but at least you will know you have tried." Her older brother supported her and said: "Don't listen to them (our parents), go ahead and found your venture". The rector of the university she was attending at the time also backed her and said: "I will provide a place of your fancy on the university premises, free of charge. Utilities will also be paid by the university."

However, as her business took off and as she went through serious employee-related problems, she developed diabetes, upon which the pressure from her father reached its peak. This time, her father said: "I will not die in peace if I do not see you working as a civil servant before I die". She believed her father wanted to protect her from the harshness of the entrepreneurial world, so partly yielding, she found a job at a state university and outsourced her manufacturing operations to a local subcontractor. From then on she engaged only in R\&D work, both for her own venture and for the local subcontractor. However, unable to contemplate closing down her business, she re-registered her company with her mother as the legal owner. In this second instance of pressure from her father, she emphasized the critical role played by the emotional support from her husband and the knowledge support from her professor.

\section{Table 1. A structured summary of the case profile as far as the process of building relationships with} stakeholders is concerned: Case A

\begin{tabular}{|c|c|c|}
\hline Period & Challenger Stakeholder & Supporter Stakeholder \\
\hline I & $\begin{array}{l}\text { 5. Technical performance monitor, } \\
\text { appointed by the ministry to provide } \\
\text { technical control over the project, expects } \\
\text { full compliance with the predefined tasks } \\
\text { of the R\&D project proposal, which turn } \\
\text { out to be unattainable due to technical } \\
\text { reasons. } \\
\text { 7. Ministry suspends the project. }\end{array}$ & $\begin{array}{l}\text { 1. Professional former banker teaches the entrepreneur how to prepare a project proposal. } \\
\text { 2. Ministry provides seed funding. } \\
\text { 3. A friend from university becomes the entrepreneur's first employee. } \\
\text { 4. Parents let the entrepreneur use their summer house as a laboratory to develop the } \\
\text { prototype. } \\
\text { 6. The project performance monitor from the ministry defends the entrepreneur } \\
\text { concerning the negative report of the technical monitor. }\end{array}$ \\
\hline II & $\begin{array}{l}\text { 9. State funding arrives after a delay of } \\
\text { eight months. Entrepreneur has serious } \\
\text { cash management problems in this } \\
\text { interim period.. } \\
\text { 13. Personnel management issues arise. }\end{array}$ & $\begin{array}{l}\text { 8. New (current) partner joins the firm, bringing the necessary knowledge and extra } \\
\text { financing. } \\
\text { 10. An accountant provides key financial information and prevents bankruptcy. } \\
\text { 11. Family apartment is mortgaged to finance the venture until the promised state funds } \\
\text { arrive. } \\
\text { 12. Second group of progress monitoring staff for state funding provides practical } \\
\text { information on where to purchase materials at affordable prices. }\end{array}$ \\
\hline Major event & \multicolumn{2}{|c|}{ A new product is developed, a patent is granted, another patent application is pending. } \\
\hline
\end{tabular}


Table 2. A structured summary of the case profile as far as the process of building relationships with stakeholders is concerned: Case B

\begin{tabular}{|c|c|c|}
\hline Period & Challenger Stakeholder & Supporter Stakeholder \\
\hline I & $\begin{array}{l}\text { 4. Potential customer of the prototype is the } \\
\text { municipality, a monopsony arises, a situation in } \\
\text { which there is only one buyer, who, in the end, does } \\
\text { not buy the product. }\end{array}$ & $\begin{array}{l}\text { 1. Ministry provides seed funding. } \\
\text { 2. Performance monitoring staff of the ministry eases bureaucratic procedures. } \\
\text { 3. The partners divide the work of running their enterprise: E.C.. undertakes } \\
\text { paperwork, H.K. carries out engineering work. }\end{array}$ \\
\hline Major event & Partners change their business idea to one where their & customer is ready. \\
\hline II & $\begin{array}{l}\text { 5. Foreign customer orders a custom design product } \\
\text { as imagined by the end-user. }\end{array}$ & $\begin{array}{l}\text { 6. Foreign customer orders a product. } \\
\text { 7. Local suppliers act as sources of knowledge. } \\
\text { 8. International suppliers provide high-quality materials. } \\
\text { 9. Accountant helps decipher legal documents. }\end{array}$ \\
\hline Major event & A manager joins the team. & \\
\hline III & $\begin{array}{l}\text { 13. Foreign customer is the ONLY customer and the } \\
\text { start-up cannot afford to lose it, grows increasingly } \\
\text { dependent upon this customer. } \\
\text { 14. Employees do not comply with workplace safety } \\
\text { standards. }\end{array}$ & $\begin{array}{l}\text { 10. Foreign customer brings in increasing amounts of business from all over the } \\
\text { world. } \\
\text { 11. Employees work overtime. } \\
\text { 12. New manager reduces costs by cutting waste, improving inventory } \\
\text { management and employee morale. }\end{array}$ \\
\hline
\end{tabular}

Another example of balancing the influence of stakeholders is illustrated in Case A. Over the course of developing the prototype promised to the ministry, the start-up in Case A faced a very negative performance assessment report written by the academician who monitors their performance from a technical point of view. The author of the report expected full compliance with the pre-specified criteria outlined in the project proposal. However, as the research progressed, the entrepreneur found that those tests were not applicable to the materials they used in the project. The progress monitor was not satisfied with this explanation and filed a negative report with the ministry. Yet, a bureaucrat monitoring the project's progress at the ministry defended their progress at an assessment meeting and helped to mitigate the punishment imposed on the company, which was the 'suspension of payment for the project until a prototype was completed'. In this case, the startup survived pressure from the ministry due to help from a ministry official. In the second period, the same entrepreneur set up another start-up and endured a major financial crisis given that the expected state grant was delayed for eight months. Although this pressure from the state was not an intentional, the urgency of the matter exerted enough pressure on the entrepreneur that he was forced to resort to the support of two major stakeholders. Following the advice of a financial advisor and relying on cash generated by the mortgage on the founding partner's family apartment, the start-up survived this period. This story is a good case supporting the stakeholder theory [Mitchell et al., 1997], where power, legitimacy and urgency are all in play.

Each start-up developed relationships with different stakeholders according to the needs of the firm at a particular time. Of particular interest are the changes in a stakeholder's position, from challenger to supporter or vice versa, depending on what they expected of the firm. Case B is a good example of a start-up that adapted to the pressing circumstances at the initial stages of founding a business, who radically changed the business and stakeholders. At the time of the establishment of the firm in case B, the monopsony of the municipality exerted too many challenges to overcome. Once the start-up successfully developed the prototype they promised to the ministry, over that first year, the ministry's progress monitor helped the entrepreneurs in such a way that E.Ç., one of the founding entrepreneurs, expressed his gratitude and said: 'I would carry him on my back. However, in the

\section{Table 3. A structured summary of the case profile as far as the process of building relationships} with stakeholders is concerned: Case $\mathrm{C}$

\begin{tabular}{|c|c|c|}
\hline Period & Challenger Stakeholder & Supporter Stakeholder \\
\hline I & $\begin{array}{l}\text { 2. Father strongly opposes the entrepreneur's } \\
\text { idea of establishing a venture. }\end{array}$ & $\begin{array}{l}\text { 1. Ministry provides seed funding. } \\
\text { 3. Older brother, her boyfriend and a professor provide emotional support. } \\
\text { 4. Professor from her alma mater provides knowledge support. } \\
\text { 5. University's rector provides incubator conditions. }\end{array}$ \\
\hline Major event & Another state grant is received, which is used to & re some former classmates as employees. \\
\hline II & $\begin{array}{l}\text { 9. Some of the employees leave, one participates } \\
\text { in shady dealings with another company using } \\
\text { the assets of the entrepreneur. } \\
\text { 10. Customers' receivable collection takes time } \\
\text { and is sometimes impossible. } \\
\text { 12. Father pressures the entrepreneur to shut } \\
\text { down her business entirely. }\end{array}$ & $\begin{array}{l}\text { 6. New employees contribute to growing manufacturing operations. } \\
\text { 7. University still provides incubation (free space and utilities). } \\
\text { 8. Professor and boyfriend still provide emotional support. } \\
\text { 11. New customers are found through connections made during a workshop for } \\
\text { female entrepreneurs. }\end{array}$ \\
\hline Major event & The entrepreneur develops diabetes, finds a job a & a civil servant, but continues work with her start-up. \\
\hline III & 13. Father still objects to the start-up. & $\begin{array}{l}\text { 14. Mother becomes a legal partner; the entrepreneur's commercial success changes } \\
\text { her father's attitude towards the venture, though he never admits it. } \\
\text { 15. Husband takes over night-time installations. } \\
\text { 16. The professor and the husband continue to provide psychological support. } \\
\text { 17. Professor continues to act as a source of knowledge and know-how. } \\
\text { 18. Local subcontractor takes over manufacturing. } \\
\text { 19. Customers' references bring in new orders and clients. }\end{array}$ \\
\hline
\end{tabular}


end, the municipality that was the founders' only client, chose not to buy their product. This situation forced the partners to act and accept an order from a foreign firm they had previously known. This firm's sustained demand gave life blood to the start-up. However, as time progressed, the company became dependent on this single client, which posed enormous challenges. E.Ç. said: "Our customer is a 200 -year-old firm in Austria... to this day, we have never marketed anything. The firm in Austria is a team for us... We cannot do this business without this Austrian firm". Thus, this stakeholder who initially helped breathe life into the venture became a trap. As Schlange [Schlange, 2009] indicates, this is a case of a stakeholder relationship changing as the venture grows. The power of this single stakeholder stems from the fact that if this customer stopped its orders, then the firm would have no other customer to turn to. Thus, it has considerable influence over the start-up and this stakeholder's power is counterbalanced and somewhat offset by the support from the firm's three other stakeholders: local suppliers, employees, and international suppliers. Local suppliers provide knowledge and the international suppliers provide high-quality materials and components for the custom-made products. Finally, the employees play a key role by working overtime to meet shipment deadlines. The evolution of this start-up also makes a case for the dynamic capabilities theory, which states that in order to meet the demands of dynamic marketplaces, firms need to develop capabilities to acquire resources and learn new ways to deploy those resources to meet the demands of the market [Zahra et al., 2006]. Dynamic capabilities are defined as "the capacity of an organization to purposely create, extend and modify its resource base" [Helfat et al., 2007, p. 4]. The change of the business in case B from one with no market to one with a client willing to place orders (indicating a potential market) is certainly an example of the deliberate reorientation of a firm towards the actual needs of the market.

In case A, after going through a number of periods of financial turmoil, eventually resorting to a business angel's investment in return for $30 \%$ of the firm, this entrepreneur's actions are also an example of 'deliberate resource base extension. Thus, these cases indicate that these entrepreneurs, were able to read the market and determine the needs of the start-ups before finding the relevant resources and new stakeholders, who could provide them.

\section{Learning emerges as a by-product of stakeholder relationships}

The entrepreneurs' approach to learning could be summarized in this one instance. One day, the founding entrepreneur's partner in case A showed him an old photo and said: 'Look, we are still not rich'. He objected by saying: 'On the contrary, we are awfully rich, we have learned so much. We did not know any of what we now know'. The interactions with stakeholders create opportunities for learning. For the entrepreneurs in case B, designing somebody's dream chandelier requires both creativity and technical problem solving, which is unique to every customer order. Therefore, in order to solve a different problem each time, they first start out with their own solution, then turn to local suppliers to refine the technical details of the complete manufacturing processes. E.C.. said: "When we founded the firm, we were located in a technopark, but in time, we opened up a place in OSTIM. Being located in OSTIM is the best thing when you need help with anything, for instance, welding. At the university, I had learned about welding in one chapter but here, there are people who have been welding for 30 years. We go and ask for their opinion and they say, "if I did not like you, I would not help" but then they do.... In return, we help that person choose the type of computer he needs to buy for his son... For us this is a trivial thing". For the entrepreneur in Case C, her knowledge source was her professor. She said: "My professor was always there for me even when he was exhausted from work. When I ask for help, he drops everything else. This person is also a dean, so he has administrative work in addition to academic work, but still he helps me. He does not even expect anything in return." As we can see from these two cases, the interaction between the stakeholders and the entrepreneurs gives the latter access to detailed knowledge on rather specific topics.

While having supportive stakeholders who are willing to share their knowledge with the entrepreneurs is a critical element, these entrepreneurs need to learn quite a lot on their own as well. For instance, the entrepreneur in case C said: "Whenever I asked for help from my accountant, he would say you can find this out on your own, so I had to learn. Sure, he gave some guidance, but I learned tax and social security procedures, all of those, on my own. Now I know enough not to depend on anyone else concerning accounting or legal matters." E.Ç., one of the founding partners in Case B, also said: "We learned tax matters and other legal matters by making mistakes. They were not lethal mistakes, thank God... Today we read all the laws and regulations related to us.... When we read a paragraph for the eighth time and still do not comprehend it, we will then resort to the financial advisor. He does not answer us a couple of times, then, we take the material to him at night and tell him that if he does not read the material, we will find another financial advisor. Then he reads and advises". These issues of 'learning by doing' have to do with investing time, but there are other instances where investing time is certainly not enough, these are examples of when 'people matter'. In both Case A and Case C, where university graduates were hired as employees, they were treated as equals by the founding entrepreneurs, however, both entrepreneurs remarked that such treatment was inappropriate and they learned this lesson the hard way. The founding partner in case A said: "There is nothing technical that cannot be solved, but human relations are tough. For instance, we used to distribute bonuses following the closure of a project. We should not have done this. Some people worked only for the bonus.... What's more, they regret their work with you in absence of a bonus and say this to your face." The entrepreneur in Case C, after the backhanded dealings of her employee, could not take the matter to court as she had no contract with the employee, who happened to be her 'friend'. After the fact, she said: "Coworkers should be people you can command and they should sign a confidentiality agreement and a non-competition agreement when joining the firm". These instances demonstrate that the entrepreneurs benefited from 'learning by doing' [Cope, 2005], which consists of lessons learned from one's own mistakes, or lessons learned after encountering and solving problems [Deakins, Freel, 1998; Young, Sexton, 1997]. Dalley and Hamilton (2000) underline the importance of experience: "It seems accepted that there are no shortcuts in the learning process, that surviving various 'trials by fire' is almost a rite of passage, and that there can never be any substitute for experience" [Dalley, Hamilton, 2000, p. 55]. 
Learning is such a key part of their venture that these entrepreneurs seek willingness to learn in their stakeholders, for instance, their employees. The founding partner in Case A said: “...when we are recruiting, we try to see if this person is curious, if they want to learn. For instance, recently we recruited a university graduate, whom we found through his website where he exhibited a quadcopter he made completely on his own. We were so excited to find such a person. He was eager to work with us. Then my partner assigned him a project to assess his abilities. This person could not do the project and was discouraged right away. Even though we tried to talk to him and make him stay with us, he went back to Adiyaman (his hometown). This taught us we should not push people too far ... What we care about is the employee's interest in problem solving... We pose a problem to him. If he is interested on his own, that is what we are after." A similar approach towards employees is also present in case B where E.Ç said: "We encourage our employees to further their education, by either helping them with their homework assignments or tutoring them on some of their class material." These instances indicate that they seek 'curiosity' and 'willingness to work hard to learn' in their employees. Yet as these entrepreneurs are not experienced in 'people management', they learn from their own mistakes, they learn how to better manage the employees. As E.Ç. in case B said: "Sometimes you may need to argue with your own staff to make them wear safety glasses. We do not want anything bad to happen to the people we work with. Money is earned and lost, but you have to keep the team going."

Learning also takes place as incidents unfold with customers and suppliers. The entrepreneur in Case C said: "There are so many people from whom I still cannot collect my receivables. ... For instance, one day before my wedding, I delivered a product to a customer and did not ask for payment then. Later, when I asked for the payment, the customer said, 'You should not have delivered the product without receiving the payment,' and this was supposed to be a lesson to me. He has not paid to this day... Today, I still deliver my products and still do not insist on immediate payment, but at least I make them sign a paper saying they received the items". The founding partner in Case A said: "Previously, we were rather naive, but now all these delays in cash collections either from customers or from the state taught us to be extra cautious... Although we signed an agreement with a business angel, I am preparing my budget as if that financing will never arrive..." The firm in case B suffered from suppliers overcharging it for materials. E.Ç. from case B said: "Let's say I bought a component from you and then I check the price on the market and realize that the market price is a third of what I paid. This happens all the time. Even the people you trust can do this once you stop price scanning."

In the literature, these experiences are referred to as the "affective" mode of learning, which is a personally experienced type of learning. The "affective mode of learning finds expression through 'being there, through immersion in an experience" [Postle, 1993, p. 33]. The different learning schemes of the entrepreneurs are summed up in the words of Gibb (1997) as: "The predominant contextual learning mode in this environment is that of...learning from peers; learning by doing; learning from feedback from customers and suppliers; learning by copying; learning by experiment; learning by problem solving and opportunity taking; and learning from making mistakes" [Gibb, 1997, p. 19].

\section{One's reputation is earned through ethical and passionate business practices}

Some of the entrepreneurs' business practices helped them gain a good reputation in the eyes of their stakeholders, particularly customers. The entrepreneur in case $\mathrm{C}$ emphasized the contribution of ethical business practices to her firm's reputation: ".. a customer comes asking for the development of a product. If we find the product on the market, we refer the customer to that firm. Most people do not behave in this way. They purchase the item and resell it to the customer. However, our behavior leaves an impression of a 'trustworthy' firm and this always has a positive return". The entrepreneurs in case B recall the first time they shipped their first order of 32 chandeliers abroad. While expecting the 'appreciation of their work' from the end-user, they received the news that all of the chandeliers were damaged during the shipment. Therefore, they had all of the products shipped back, fixed them one by one, and this time carefully packaged them for a safe trip. Eventually, the enduser was happy with the result and their behavior proved their 'trustworthiness' in the eyes of their customer. The literature underlines the significance of ethical business practices: "Personal reputation is an important asset, because it reduces uncertainty concerning future behavior by signaling that the individual is trustworthy and has the necessary abilities to deal with workplace demands" [Neves, Story, 2015, p. 172].

In his eight years of research on entrepreneurs Sirolli [Sirolli, 2003] concluded that the essential ingredient of entrepreneurship is 'passion'. E.Ç. in Case B said: "Have you ever seen a cat that could ignore playing with a ball of yarn? To us that is how a new order is, we like solving problems... I can do any other job, like sweeping floors or working in sewage or xeroxing at a bank, but people would think I am a psychopath because when I am xeroxing a document, that paper has to be placed perfectly in the machine.... We have a lot of obsessions like this. If something does not turn out as it is supposed to, we continue to work on it until we are satisfied... We are constantly in search of excellence..." The same passion for new product development is also apparent in the entrepreneur in case $\mathrm{C}$ who said: "I do not sell an existing product just because there is a market for it. It is something that I can sell, but I do not get any joy out of it. I like developing new products." The entrepreneur in case A said: "My partner and I have a notebook in which we write down our business ideas. We like developing new things. Our goal in the future is to buy 10-20 acres of land and start an R\&D center where people can live and work." The passion to generate new products, meet technological challenges head-on is a common driving force found among these three entrepreneurs.

\section{Discussion}

Most research assumes that family will be supportive of a new venture [Brüderl, Preisendörfer, 1998]. Family is seen as provider of emotional support in the establishment stage of a venture and a source of tacit knowledge. The entrepreneur enjoys trusted feedback from their family members regarding business ideas [Rosenblatt et 
al., 1985]. As entrepreneurs prefer to discuss their ideas in confidence, they feel secure talking to their family members [Greve, Salaf, 2003]. Furthermore, family also often acts as the provider of initial capital [Anderson et al., 2005; Greve, Salaf, 2003; Conti et al., 2013]. However, the findings of our work revealed some unexpected conclusions. One was the case of family acting as the key provider of critical finance by mortgaging the family apartment. This case is in line with the literature [Bygrave et al., 2003], but then there was the case a family member acting as the biggest obstacle to the entrepreneur's start-up. One piece of research [Anderson et al., 2005] described the case of an entrepreneur who would not let his son work at his firm thinking that it would damage his son's development. Thus, the following could be proposed:

Hypothesis 1: Family members' strong opposition to an entrepreneur's start-up efforts could simply arise in order to 'protect' the entrepreneur from potential harm caused by such a risky endeavor.

Yet such a proposition merits further research because this specific case could be an idiosyncratic one. First, whether or not this is a unique case should be studied and secondly, if this case is not an anomoly, then more data should be collected to elucidate the reasons behind such 'protective' behavior.

In Turkey, while the state aims to support entrepreneurship, the people who carry out these well-intended policies may not be acting in compliance with the state's final goal. As the above cases illustrate, the performance monitoring staff of the state, who are appointed to assess the performance of start-ups, may either pave the way for the entrepreneur, clearing the road of bureaucratic obstacles, or may kill a start-up in its infancy for not complying with the myriad bureaucratic procedures. Since these people are 'acting' stakeholders in the name of the state, the entrepreneur needs to adhere to the predefined success criteria of the project expected by the state. In the literature, researchers suggest that this inflexible attitude of the state staff might be explained by 'causation driven logic' while the problem-solving and creativity-based approach of the entrepreneurs could be classified as effectuation (situational) driven logic [Sarasvathy, 2008].

Sarasvathy explains the difference between causal and effectual (situational) thinking by giving the example of two chefs [Ibid.]. In the causal case, the chef starts the cooking process by first picking a menu. Then he finds the recipes for each item on the menu. Next, he does the necessary shopping for ingredients, arranges the pots and pans, and all the relevant other material and finally cooks the meal. The causal process starts with the goal and proceeds with consecutive, well-planned steps to achieve the goal. In the effectual case, the chef first checks the kitchen to see what ingredients and materials are available. Then he designs the menus based on what he has on hand. As a matter of fact, the menu is created along with the meal. The effectual chef starts with what he finds in the kitchen, and 'designs' possible dishes according to the ingredients on hand.

Dutta and Thornhill [Dutta, Thornhill, 2014, p. 156] state that entrepreneurs "may become compelled to adopt a causation-oriented cognitive logic for the venture under pressure from external investors that expect the entrepreneur to provide a detailed, incremental business plan with clearly articulated future scenarios for the venture ..." In the three cases that were presented in this paper, the pressure from the state was exerted if the firms did not follow causal logic and state officials empathized compliance with the prespecified plans that were made before the venture was even started. Furthermore, a study based on six years of longitudinal data [Honig, Samuelson, 2009] finds no significant positive relationship between business planning and commercial performance. Thus, the following proposition could be made based on the cases analyzed here.

Hypothesis 2: Differences between the mindsets of the state and the entrepreneur, such as those between causal and situational logic, prematurely end potentially successful ventures.

Ethical and passionate business practices are common traits that these three entrepreneurs share. The ethical conduct of a business reflects their stance in the business world and they believe this has benefits in the form of 'a good reputation', which may bring in future stakeholders, i.e., customers. At this point, one wonders, what do the customers feel about the ethical practices of a no-name start-up? How would the passionate attitude of these entrepreneurs affect their stakeholders? These two questions lead one to propose the following:

Hypothesis 3: Ethical and passionate business practices leave a positive impression on third parties cooperating with the start-up, and they may in turn become stakeholders in the future due to the traits they witness before investing in the enterprise.

\section{Conclusion}

The aim of this paper was to explore the process of building relationships with stakeholders carried out by R\&Dbased start-ups established after receiving the techno-entrepreneurship grant in Turkey. To this end, in-depth interviews with the founders of three start-ups were conducted and analyzed. When analyzed chronologically, the stakeholder formation process exhibited a structure where challenger and supporter stakeholders were present at two opposing sides of the start-up where the entrepreneur benefited from the counterbalancing effect of these forces. Two major stakeholder groups emerged at the founding stage of the businesses: the family members and the state's grant-handling officers.

The predominant finding in the literature was the supportive role of the family, however, in one of the cases, we found a profound opposing force posed by one of the family members. Is this opposing force of the family a unique case or is it representative of a subset of techno-entrepreneurs in Turkey? This should be the subject of further study. Secondly, the logic of the state's techno-entrepreneurship fund monitoring staff seems to be a vital factor in the sustainability of the start-ups and the relationships in which entrepreneurs choose to invest. Thus, such staff's flexibility in understanding the mindsets of the entrepreneurs should be studied further. Finally, the ethical and passionate conduct of business by these start-ups could be a factor drawing third parties in to become stakeholders of these new firms. Therefore, this too could be the subject of further research. 


\section{References}

Anderson A.R., Jack S.L., Dodd S.D. (2005) The role of family members in entrepreneurial networks: Beyond the boundaries of the family firm. Family Business Review, vol. 18, no 2, pp. 135-154.

Bazerman M.H., Neale M.A. (1992) Negotiating rationally, New York: Free Press.

Brüderl J., Preisendörfer P. (1998) Network support and the success of newly founded businesses. Small Business Economics, vol. 10, no 3, pp. 213-225.

Bygrave W.D., Hay M., Ng E., Reynolds P. (2003) A Study of Informal Investing in 29 Nations Composing The Global Enterprise Monitor. Venture Capital: An International Journal of Entrepreneurial Finance, vol. 5, pp. 101-116.

Conti A., Thursby M., Rothaerme F. (2013) Show Me the Right Stuff: Signals for High-Tech Startups. Journal of Economics \& Management Strategy, vol. 22, no 2, pp. 341-364.

Cope J. (2005) Toward a dynamic learning perspective of entrepreneurship. Entrepreneurship Theory and Practice, vol.29, no 4, pp. 373-397.

Coviello N.E., Jones M.V. (2004) Methodological Issues in International Entrepreneurship Research. Journal of Business Venturing, vol. 19, no 4, pp. 485-508.

Dalley H., Hamilton B. (2000) Knowledge, context and learning in the small business. International Small Business Journal, vol. 18, no 3, pp. 51-59.

Daniels C., HoferC. (1993) Characteristics of successful and unsuccessful entrepreneurial faculty and their innovative research teams. Frontiers of Entrepreneurship Research (eds. N. Churchill, S. Birley, W. Bygrave, J. Doutriaux, E. Gatewood, F. Hoy, W. Wetzel), Wellesley, MA: Babson College, pp. 598-609.

Deakins D., Freel M. (1998) Entrepreneurial learning and the growth process in SMEs. The Learning Organisation, vol. 5, no 3, pp. 144-155.

Dutta D.K., Thornhill S. (2014) Venture Cognitive Logics, Entrepreneurial Cognitive Style and Growth Intentions: A Conceptual Model and an Exploratory Field Study. Entrepreneurship Research Journal, vol. 4, no 2, pp. 147-166. DOI: $10.1515 /$ erj-2012-0004.

Eriksson P., Kovalainen A. (2008) Qualitative methods in business research, London: Sage.

Evers N., Andersson S., Hannibal M. (2012) Stakeholders and Marketing Gapabilities in International New Ventures: Evidence from Ireland, Sweden, and Denmark. Journal of International Marketing, vol. 20, no 4, pp. 46-71.

Freeman R.E. (1984) Strategic management: A stakeholder approach, Cambridge, MA: Pitman.

Frooman J. (1999) Stakeholder influence strategies. Academy of Management Review, vol. 24, pp. 191-205.

Gans J.S., Stern S. (2003) The product market and the market for ideas: Commercialization strategies for technology entrepreneurs. Research Policy, vol. 32, no 2, pp. 333-350.

Gibb A.A. (1997) Small firms' training and competitiveness: Building on the small business as a learning organization. International Small Business Journal, vol. 15, no 3, pp. 13-29.

Greve A., Salaff J.W. (2003) Social networks and entrepreneurship. Entrepreneurship Theory and Practice, vol. 28, no 4, pp. 1-22.

Helfat C.E., Finkelstein S., Mitchell W., Margaret P., Singh H., Teece D., Winter S.G. (2007) Dynamic Capabilities: Understanding Strategic Change in Organizations, London: Blackwell.

Honig B., Samuelson M. (2009) Business planning and venture level performance: Challenging the institution of planning (Swedish Entrepreneurship Forum WP no 05), Örebro: Örebro University Available at: http://entreprenorskapsforum. se/wp-content/uploads/2013/03/WP_05.pdf, accessed 31.01.2016.

Julien P. (1995) New technologies and technological information in small businesses. Journal of Business Venturing, vol. 10, no 6, pp. 459-475.

Lawler E.)., Yoon J. (1996) Commitment in exchange relations: Test of a theory of relational cohesion. American Sociological Review, vol. 61, no 1, pp. 89-108.

Maxwell J.A. (1996) Qualitative Research Design: An Interactive Approach, Thousand Oaks, CA: Sage.

Mitchell R.K., Agle B.R., Wood D.J. (1997) Toward a theory of stakeholder identification and salience: Defining the principle of who and what really counts. Academy of Management Review, vol. 22, no 4, pp. 853-886.

MSIT (2014) 2009-2014 Teknogirişim Dönem Raporu [2009-2014 Techno Entrepreneurship Report], Ankara: Turkish Ministry of Science, Industry and Technology. Available at: http://sagm.sanayi.gov.tr/userfiles/file/ Teknogiri\%C5\%9Fim\%20Sermayesi\%20Deste\%C4\%9Fi/TGSD\%2009-14\%20D\%C3\%96NEM\%20RAPORU\%20 REV\%C4\%B0ZYON\%200409.pdf, accessed 19.03.2016 (in Turkish).

Neves P., Story J. (2015) Ethical Leadership and Reputation: Combined Indirect Effects on Organizational Deviance. Journal of Business Ethics, vol. 127, pp. 165-176.

OECD (2003) The Policy Agenda for Growth, Paris: OECD.

Patton M.Q. (2002) Qualitative Research and Evaluation Methods, Thousand Oaks, CA: Sage.

Pfeffer J., Salancik G. (1978) The external control of organizations: A resource dependence perspective, New York: Harper \& Row.

Postle D. (1993) Putting the Heart Back into Learning. Using Experience for Learning (eds. D. Boud, R. Cohen, D. Walker), Buckingham: SRHE, Open University Press, pp. 33-45.

Rosenblatt P.C, de Mik L., Anderson R.M., Johnson P.A. (1985) The Family in Business, San Francisco, CA: Jossey-Bass.

Sarasvathy S., Venkatamaran S. (2011) Entrepreneurship as Method: Open Questions for an Entrepreneurial Future. Entrepreneurship Theory and Practice, vol. 35, no 1, pp. 113-135. DOI: 10.1111/j.1540-6520.2010.00425.x

Sarasvathy S.D. (2001) Causation and effectuation: Toward a theoretical shift from economics inevitability to entrepreneurial contingency. Academy of Management Review, vol. 26, no 2, pp. 243-263.

Sarasvathy S.D. (2008) Effectuation: Elements of Entrepreneurial Expertise, Cheltenham: Edward Elgar.

Schlange L.E. (2009) Stakeholder identification in sustainability entrepreneurship: The role of managerial and organisational cognition. Greener Management International, vol. 55, pp. 13-32.

Scottish Executive (2001) A Smart Successful Scotland: Ambitions for the Enterprise Networks, Edinburgh: HM Stationary Office.

Sirolli E. (2003) Ripples from the Zambesi. Passion. Entrepreneurship and the rebirth of local economies, Gabriola Island, Canada: New Society Publishers.

Steyaert C. (1997) A qualitative methodology for process studies of entrepreneurship: Creating local knowledge through stories. International Studies of Management and Organization, vol. 27, no 2, pp. 13-33.

Strauss A.L., Curbin J.M. (1990) Basics of Qualitative Research: Techniques and Procedures for Developing Grounded Theory, Thousand Oaks, CA: Sage.

Thompson L., Gentner D., Loewenstein J. (2000) Avoiding missed opportunities in managerial life: Analogical training more powerful than individual case training. Organizational Behavior and Human Decision Processes, vol. 82, no 1, pp. 60-75.

Young J.E., Sexton D.L. (1997) Entrepreneurial Learning: A Conceptual Framework. Journal of Enterprising Culture, vol. 5, no 3, pp. 223-248.

Zahra H., Sapienza J., Davidsson P. (2006) Entrepreneurship and Dynamic Capabilities: A Review, Model and Research Agenda. Journal of Management Studies, vol. 43, no 4, pp. 917-955. 


\title{
The Choice of Funding Sources for Start-Ups in a Transitional Economy: The Ability to Predict in a National Context
}

\author{
Olga Obraztsova ${ }^{\text {a }}$ \\ Assistant Professor, Moscow School of Economics, olga_obraztsova@rambler.ru \\ Tatiana Poliakova ${ }^{\text {a }}$ \\ PhD Student, Chair of Statistics, Economic Faculty, tatyana-zabelova@yandex.ru \\ Ekaterina Popovskaya ${ }^{b}$ \\ Analyst, Laboratory of Entrepreneurship Research, epopovskaya@hse.ru \\ a Lomonosov Moscow State University, 1, bld. 46, Moscow 119234, Russian Federation. \\ b National Research University Higher School of Economics, 20, Myasnitskaya str, Moscow 101000, \\ Russian Federation.
}

\begin{abstract}
$\mathrm{D}$ espite the government's efforts to support entrepreneurship, the major share of startup funding in transitional economies comes from the owners' own funds and "love capital" rather than from institutional sources (banks, venture funds, etc.). This increases the asymmetry of information concerning the capabilities of the emerging businesses for potential investors, and thus hinders the development of entrepreneurship as a whole.

The paper considers the key determinants affecting the decisions made by entrepreneurial start-ups when choosing from a number of ways to finance their business in transitional economies. An attempt has been made to build models for an adequate prediction of the financial strategies of early entrepreneurs. A number of hypotheses have been put forward to verify external and internal factors influencing the financial choices of early entrepreneurs.

Hypotheses were tested on a survey sample of early entrepreneurs from seven transitional economies,

including Russia. The predictive values of the final models proved to be effective in predicting start-ups' financial strategies and in comparing the probability of early entrepreneurs borrowing capital.

Our findings confirm that the combinations of external and internal financing differ significantly depending on the national macroeconomic and social context. Given that simple borrowing mechanisms for supporting a business can lead to an undesirable tendency to avoid formal borrowed funds altogether, such behavior can hinder the development of entrepreneurship. The obtained results show that pessimistic short-term expectations about the conditions for entrepreneurship in a region aggravate this problem in Russia. The outcomes demonstrate a need to reduce the burden on start-up businesses and to improve entrepreneurial aspirations by encouraging confidence in a start-up's future and find the optimal proportion of borrowed sources in a business's capital structure.
\end{abstract}

Keywords: entrepreneurial activity; early entrepreneurs; financial choice factors; Fisher's linear discriminant; borrowed funds; love capital; cross-country comparisons; contextual approach.
Citation: Obraztsova O., Poliakova T., Popovskaya E. (2017) The Choice of Funding Sources for Start-Ups in a Transitional Economy: The Ability to Predict in a National Context. Foresight and STI Governance, vol. 11, no 3, pp. 71-81. DOI: $10.17323 / 2500-2597.2017 .3 .71 .81$ 
$\mathrm{M}$ any experts see entrepreneurship as a driver of positive change in a country, and the foundation for balanced, sustainable growth of a market economy. In recent decades, providing support for entrepreneurship has become a priority for economic policy in most countries, especially those undergoing systemic transformation. This applies to Russia and other countries - the members of the Commonwealth of Independent States (CIS), and Central and Eastern European (CEE) nations.

A developed entrepreneurial sector typically indicates a high level of the national economy and its ability to adapt to changing market situations [Beck et al., 2008]. However, the determinants, structure, and dynamics of entrepreneurship in the context of economic restructuring and radical macroeconomic shifts are quite different from those in advanced economies with strong entrepreneurial traditions, long experience, and a stable socioeconomic and political environment.

In Russia, this new model of economic activity has emerged at a much slower rate than in many CEE countries, given the complete lack of relevant experience and theoretical knowledge. Conversely, in Hungary and Poland, a sufficiently strong private sector (which existed even before the beginning of the transitional period) served as a basis for the development of small and medium enterprises (SME).

Enterprise surveys conducted by the World Bank (World Bank Enterprise Surveys, WBES) [Yang et al., 2013] have revealed that in Russia the emergence of new companies and development of existing ones are hindered by three major institutional barriers: a complex taxation system, insufficient access to financial resources, and corruption. More than $15 \%$ of companies noted the inadequately developed financial system as the main hurdle, and, as a consequence, the lack of investment capital, which makes Russia to noticeably stand out among the 123 countries covered by the aforementioned survey.

Therefore, access to the necessary financial resources turns out to be among the more relevant issues. Numerous studies address it in the context of providing support to large corporations, on the basis of conventional corporate funding theories [Klapper et al., 2006; Beck et al., 2008]. Yet, the limited availability of investments hinders the development of small entrepreneurship even more, especially at the early stages. Over the last ten years, access to formal funding mechanisms has been steadily getting more difficult for entrepreneurs at the early stage of their firms' development. According to Global Entrepreneurship Monitor (GEM) data, in 2006 the share of institutional loans was 19\% higher than that of funds received through informal support. However, already in 2007, the situation had changed quite dramatically: only about $40 \%$ of the money invested in start-up companies came from official sources [Murzacheva, Obraztsova, 2008]. Subsequently, the above negative trends were exacerbated: the amount of loans that start-ups in transitional economies received as official investments did grow, but the number of entrepreneurs making do with "love capital" grew as well. As a result, the latter's share in the structure of early-stage entrepreneurs' capital is currently $35-40 \%$ greater than the amount of officially obtained funds. According to an expert poll conducted in the framework of the GEM, by the beginning of 2017, difficult access to official funding became the major hurdle not only hindering the development of entrepreneurship in transitional economies, but actually threatening its very survival [GERA, 2017].

The resulting structure of capital available to early-stage entrepreneurs, with the dominating shares of one's own resources and "love capital", increases the probability of default on the micro- and macroeconomic levels and slows down the development of entrepreneurship - despite the officially implemented support programs. This is primarily due to the fact that, according to the asymmetric information theory, the choice between external and one's own capital is a qualitative signal that businesses send to financial markets. It is particularly important for early-stage entrepreneurship because potential investors do not see prospects for its development.

Accordingly, we have tried to identify factors affecting early-stage entrepreneurs' choice of funding sources, and assess the predictability of such choices. Our analysis was based on a contextual approach and took into account the impact of country-specific socioeconomic conditions on the development of entrepreneurship in transitional economies. The microdata collected in the framework of the GEM project served as the empirical basis of this study.

The subsequent sections present the theoretical foundation of the study; put forward a number of hypotheses; describe the databases and empirical techniques; and summarize the results of the analysis, with a discussion. The final section formulates our main conclusions, and the applicability of the study results in terms of affecting the capital structure of early-stage entrepreneurship.

\section{Theoretical basis and hypotheses}

Many researchers [Yang et al., 2012; Chavis et al., 2011; Beck et al., 2008; Aidis, 2005; Levine, 2005; Djankov et al., 2002] believe that access to financial resources is the fundamental factor affecting the conditions for 
and strategy of starting a new business. Depending on the specific national context, this factor can either mobilize entrepreneurial activity or, conversely, create barriers hindering the launch of new enterprises. Despite the fact that bank-based SME funding formats and micro financing programs alike have been actively developing in all transitional economies over recent years, in many cases they still could not meet the companies' demand for resources. In most such countries, including Russia, an entrepreneur's own funds and "love capital" continue to dominate as sources of early-stage support, since they do not require economic returns and create fewer problems with confidence and repayment periods [Murzacheva, 2011]. Accordingly, by analyzing the specific features of early-stage entrepreneurship in the context of a transitional economy, particularly the conditions affecting start-up companies' choice of support providers, seems to be a relevant field of study in terms of increasing the effectiveness of government policies to support SMEs.

Factors affecting new companies' emergence and growth rates cannot be thoroughly analyzed due to the significant uncertainty of these processes, which is caused by a variety of factors. Still, it has been established that the success of entrepreneurial activities does depend upon external framework conditions, which in turn are affected by the economic, social, political, institutional, spatial, temporal, historical, and other contexts [Welter, 2011].

It has been proven that companies' capital structure and access to external funding sources depend on country-specific features [Antoniou et al., 2008]. Researchers in the area of entrepreneurship theory [Audretsch, Thurik, 2004; Levine, 2005; Yang et al., 2013; Chavis et al., 2011; Hashi, 2001; Shane, Wenkataraman, 2000; Glas et al., 2000; et al.] agree with this argument, and cite inadequate access to sources of sufficient investments among the factors limiting the creation of new companies. However, the authors of the above studies mainly focus on funding arrangements available to private companies in countries with an Anglo-Saxon market economy model, which typically feature developed and efficient capital markets and a high level of bank competition. On the other hand, in transitional economies, entrepreneurship faces considerable barriers and high transaction costs associated with obtaining access to capital (relevant markets began to emerge in CEE and CIS countries only in the early 1990s, and still remain rather undeveloped) [Gerasimova, 2012]. Therefore it would not be correct to directly extrapolate the conclusions about the specific features of funding for early-stage entrepreneurs in developed market economies to countries with transitional economies, including Russia.

The issues associated with providing support to entrepreneurship in transitional economies, and ways to deal with them remain at the center of many researchers' attention [Yang et al., 2012; Chavis et al., 2011; Beck et al., 2008; Aidis, 2005; Levine, 2005; Djankov et al., 2002]. However, no comparative studies of the effect of the national socioeconomic context on early-stage entrepreneurs' choice of specific funding sources have yet been conducted.

Klapper et al. [Klapper et al., 2006] established that in most of the 15 analyzed developing countries external funding was not particularly important to entrepreneurs (least of all in Ukraine). Limited access to resources can be explained not only by the low level of trust in early-stage entrepreneurs as economic agents, but also by a widespread sceptical attitude toward the very possibility of setting up and running a successful innovative company in post-socialist countries [Berger, Schaeck, 2010].

The probability of early-stage entrepreneurs' attracting external investments increases if their business idea is innovative and involves the production of goods or services new to the market. This factor appears to outweigh the fears of failure [Yang, 2012; Welter, Smallbone, 2011; Robb, Robinson, 2010].

Certain "rules of the game" for the entrepreneurial sector have by now been developed in countries with transitional economies. Firms at an early stage of their life cycle, which do not yet steadily generate revenues by selling the goods and services they produce, find it harder to get banks, investment companies, and venture funds interested [Murzacheva, 2011]. The inadequate legal and regulatory systems, a lack of transparency concerning lenders' solvency, and a negative social attitude toward entrepreneurship in general result in start-up companies' increased dependence on unofficial funding sources [Chavis et al., 2011]. The modernization of the legal system, more transparent credit history information, and the media promoting a positive image of entrepreneurship as a career would help make official investments more accessible to such businessmen.

A typical feature of financial capital markets for small entrepreneurs in Russia, and in the vast majority of CEE countries, is the lack of funding organizations' trust in private businesses. This trend is further aggravated by the insufficient transparency of financial markets, and the asymmetry of available information. Investors who have actually invested in a new company know more about it than other potential sources of support, and tend not to be too keen on sharing this information. Typically, they are more willing to invest in new firms established by entrepreneurs they know. As a consequence, many early-stage entrepreneurs who do not yet have credit histories have rather limited opportunities for securing loans [Black, 2009]. 


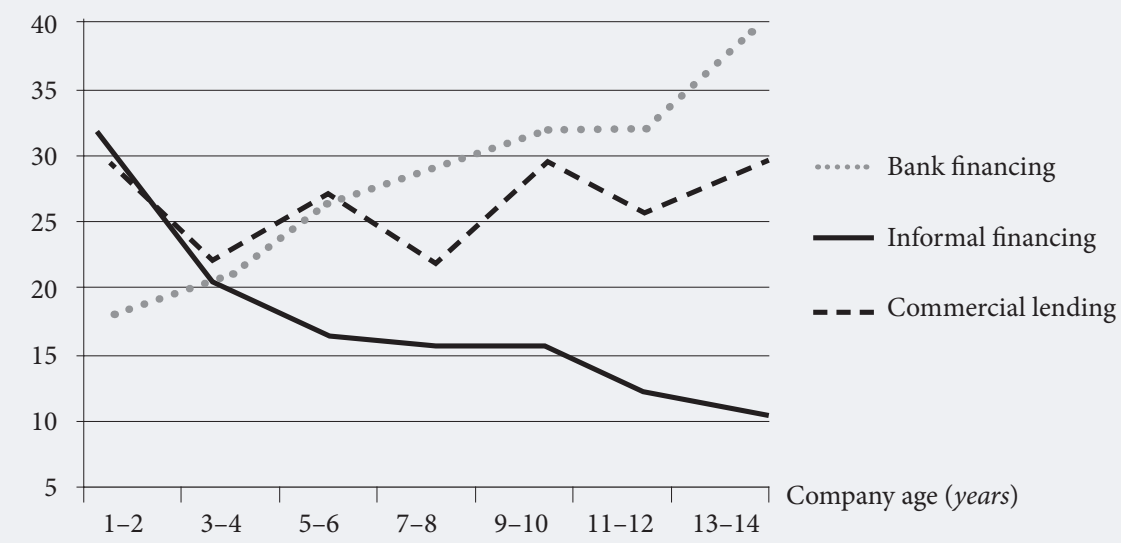

Source: [Chavis et al., 2011].

Accordingly, researchers break down the funding sources companies are most likely to find on the basis of these companies' development stage [Chavis et al., 2011]. According to the "pecking order" theory, established companies usually have higher profitability combined with partially exhausted growth potential, so they have more resources of their own (unallocated profits), which they primarily use. On the other hand, early-stage entrepreneurs have practically no such opportunities because it usually takes at least three years to reach the break-even point and begin making profits [Chavis et al., 2011]. In addition, a faultless reputation and a good credit history will help solve some of the funding problems created by asymmetrical information. Unlike early-stage firms, mature companies can get more favorable loan terms [Chavis et al., 2011]. Accordingly, the share of external investments, especially bank loans, in the capital structure of small companies is significantly smaller compared with that of larger businesses [Beck et al., 2008].

Apart from the lack of an established reputation and credit and trading histories, small companies also encounter problems when they try to obtain loans because they cannot provide loan security [Verheul, Thurik, 2001]. High interest rates and difficult terms turn into insurmountable obstacles for many early-stage entrepreneurs [Yang et al., 2013]. For example, a survey of 800 SMEs in Southeastern European countries (Bosnia and Herzegovina, Macedonia, Slovenia) revealed that the high costs of credit and loans was the most difficult hurdle to overcome, thus hindering the creation of new firms in Slovenia and Macedonia, though not in Bosnia and Herzegovina [Aidis, 2005]. Still, the lack of one's own resources and the insufficient appeal (or availability) of institutional investments for earlystage entrepreneurs increase the importance of informal sources, such as "love capital" and funding provided by business angels willing to support an idea by providing a loan [Yang et al., 2013].

Such funding sources, especially "love capital," are particularly attractive to young companies in transitional economies, including Russia. The situation changes as the companies grow and the number of their employees increases (Figure 1). To avoid bureaucratic and other institutional barriers, earlystage entrepreneurs do accept informal investments, though by doing so they risk facing problems like unreliability, the irregular provision of funds by friends and relatives, unprofessional assessments of their business ideas, and "significant non-monetary costs" [Djankov et al., 2002]. The correlation between early-stage entrepreneurs' choice of funding sources and the income level in the country is shown in Table 1. Having a stable financial market reduces entrepreneurs' dependence on external loans and promotes business activities in the economy at large [Robb, Robinson, 2010].

An analysis of the literature on the specific features of early-stage companies' funding in transitional economies allowed us to formulate several hypotheses:

Hypothesis 1: The set of factors affecting early-stage entrepreneurs' choice of funding sources depends on the national socioeconomic context.

Hypotheses 2-4: Early-stage entrepreneurs' choice of external funding sources in transitional economies is promoted by the following:

- A favorable institutional environment for starting one's own business; 
Table 1. Correlation between income level in the country and preferred sources of funding

\begin{tabular}{|l|l|}
\hline \multicolumn{1}{|c|}{ Income level (according to the World Bank classification) } & \multicolumn{1}{c|}{ Main sources of support for businesses } \\
\hline High or above average & Leasing \\
\hline Low & Informal funding \\
\hline All levels other than low & Active use of bank loans \\
\hline * Low-income countries typically have poorly developed financial systems and limited access to investments. \\
Source: composed by the authors, based on the data in [Djankov et al., 2002].
\end{tabular}

- Innovative business ideas, good prospects for marketing new products or services that prevail over fears of failure;

- The promotion of a positive image of entrepreneurship in the media.

\section{Initial data and methodology}

Our research is based on data collected as part of the GEM surveys. The GEM project is focused on developing common international methodological standards for monitoring, which would allow one to obtain a realistic picture of the state of entrepreneurship and the role it plays in various economies. Russia has participated in the GEM since 2006. In 2016, the survey covered more than 200,000 adult, able-bodied people in more than 100 countries $^{1}$. A standardized questionnaire ${ }^{2}$ is used to collect data in all participating countries. The results are integrated into a single bank of open, comparable data, and include information about entrepreneurial behavior at various stages: from the emergence of an idea to run an established business, which allows one to assess businessmen's financial strategies. The GEM microdata furthermore makes it possible to empirically analyze strategies employed by early-stage entrepreneurs who, due to various reasons, were missed by official statistics [Obraztsova, 2010].

According to the GEM methodology, early-stage entrepreneurs are divided into two groups [Reynolds et al., 2005]:

- nascent entrepreneurs, who fully or partially own their business and were actively setting it up over the course of the previous year, and if they did receive any income from it, it was only profitable for no more than three and a half months;

- new businesses owners (NBO), who received income from their companies over a period ranging between three and a half months to three and a half years.

According to the basic concept, the array of microdata about early-stage entrepreneurs in transitional economies was built using variables calculated on the basis of answers to the following questions:

- Q1A: Are you currently trying to set up a new business on your own or in partnership, which would stipulate self-employment or selling products/services to customers?

- Q1B: Are you currently trying to set up a new business on your own or in partnership, for your employer, in the course of performing your work? [Reynolds et al., 2005].

On the basis of the microdata collected in the scope of a representative survey using the above tool, a multistage stratified probabilistic sample was constructed for analysis purposes. To ensure its validity and compatibility with the characteristics of the general adult able-bodied population of the relevant countries, the sample data was weighted by the respondents' gender and age.

In line with the methodology presented in [Holm, 1979], country-specific data was made compatible, while annual values were tested for belonging to the overall general population (Spearman's correlation coefficient (rho), Holm-Bonferroni correction for multiple comparisons, $\alpha=0.01$ ). On that basis, by combining the databases for four years (2008-2011) for all countries, we put together the array of data for analysis. Combining the databases allowed us to analyze the dynamics of early-stage entrepreneurs' choice of funding sources by comparing various periods of the countries' socioeconomic development [Yang et al., 2013]:

- 2008: relatively high economic growth rates, mostly favorable conditions for entrepreneurship;

- 2009: the emergence of a full-scale financial and economic crisis in all European countries;

- 2010-2011: overcoming the acute phase of the crisis, eliminating its negative effects, the emergence of pre-requisites for economic growth, including in the entrepreneurial sector.

\footnotetext{
Available at: http://www.gemconsortium.org/country-profiles, accessed 12.10.2016.

${ }^{2}$ Available at: http://www.gemconsortium.org/data/sets, accessed 12.10.2016.
} 
Table 2. Variables used in the analysis

\begin{tabular}{|c|c|c|c|}
\hline № & Variable & Code & Value \\
\hline \multicolumn{4}{|c|}{ Criterion variable } \\
\hline \multirow{2}{*}{1} & \multirow{2}{*}{ Funding source } & \multirow{2}{*}{ OwnF_BorrF } & 0: One's own funds \\
\hline & & & 1: Borrowed funds \\
\hline \multicolumn{4}{|c|}{ Predictor variable } \\
\hline \multirow{3}{*}{1} & \multirow{3}{*}{ Education level } & \multirow{3}{*}{ Education } & $\begin{array}{c}\text { 1: Low (no or incomplete secondary, or incomplete } \\
\text { vocational education) }\end{array}$ \\
\hline & & & $2:$ Medium (secondary or vocational education) \\
\hline & & & 3: High (tertiary education) \\
\hline \multirow{2}{*}{2} & \multirow{2}{*}{$\begin{array}{l}\text { Know somebody personally who started a business } \\
\text { during over the past two years }\end{array}$} & \multirow{2}{*}{ KNOWEN } & $0:$ No \\
\hline & & & 1: Yes \\
\hline \multirow{2}{*}{3} & \multirow{2}{*}{$\begin{array}{l}\text { Expect favourable conditions for starting one's own } \\
\text { business to be in place in the area of residence in } \\
\text { the next six months }\end{array}$} & \multirow{2}{*}{ OPPORT } & $0:$ No \\
\hline & & & 1: Yes \\
\hline \multirow{2}{*}{4} & \multirow{2}{*}{$\begin{array}{l}\text { Possess the knowledge, qualifications, and skills } \\
\text { required to start a new business }\end{array}$} & \multirow{2}{*}{ SUSKIL } & $0:$ No \\
\hline & & & 1: Yes \\
\hline \multirow{2}{*}{5} & \multirow{2}{*}{$\begin{array}{l}\text { Fear or inadequate abilities prevent starting a new } \\
\text { business }\end{array}$} & \multirow{2}{*}{ FRFAIL } & 0: No \\
\hline & & & 1: Yes \\
\hline \multirow{2}{*}{6} & \multirow{2}{*}{ Prefer a similar standard of living for everyone- } & \multirow{2}{*}{ EQUALI } & 0: No \\
\hline & & & 1: Yes \\
\hline \multirow{2}{*}{7} & \multirow{2}{*}{$\begin{array}{l}\text { Starting one's own business as a desirable career } \\
\text { choice }\end{array}$} & \multirow{2}{*}{ NBGOOD } & $0:$ No \\
\hline & & & 1: Yes \\
\hline \multirow{2}{*}{8} & \multirow{2}{*}{$\begin{array}{l}\text { People who start their business have a high level of } \\
\text { status and respect }\end{array}$} & \multirow{2}{*}{ NBSTAT } & $0:$ No \\
\hline & & & 1: Yes \\
\hline \multirow{2}{*}{9} & \multirow{2}{*}{$\begin{array}{l}\text { Regular coverage stories about successful new } \\
\text { businesses in the public media }\end{array}$} & \multirow{2}{*}{ NBMEDI } & $0:$ No \\
\hline & & & 1: Yes \\
\hline 10 & Shut down a business during the previous year, and & DISCFN & 0: No \\
\hline 10 & never resumed it & DISCEN & 1: Yes \\
\hline 11 & Expectation to start a new business over the next & FUTSUP & 0: No \\
\hline 11 & three years & FUISUP & 1: Yes \\
\hline & & & 1: Yes, all customers think so \\
\hline 12 & $\begin{array}{l}\text { Offering a product (service) that is new or } \\
\text { unfamiliar to customers }\end{array}$ & SUNEWCST & 2: Yes, some customers think so \\
\hline & & & 3: No, everybody knows about this product or service \\
\hline
\end{tabular}

The timeframe of the study was determined by its main objective: to examine the specific features of early-stage entrepreneurs' choice of funding sources when affected by the economic and social change engendered by the global crisis (while keeping in mind the period of Russia's participation in the GEM project).

Of all the countries taking part in the GEM, the CEE nations were chosen for international comparison: they, like Russia, have gone through a planned economy followed by a period of market reforms accompanied by institutional and social transformations. We managed to ensure the necessary completeness, adequacy, and quality of the microdata for a comparative analysis of seven countries: Russia, Hungary, Romania, Latvia, Croatia, Slovenia, and Bosnia and Herzegovina. Logical and content control was applied to make sure that the early-stage entrepreneurs' sample included only the respondents who answered the GEM questionnaire's questions (the ones who were unable or refused to answer were eliminated). The final sample included 2,360 observations: 167 for Russia, 377 for Hungary, 232 for Romania, 604 for Latvia, 248 for Croatia, 372 for Slovenia, and 360 for Bosnia and Herzegovina.

Each of the early-stage entrepreneurs' answers were analyzed using target indicators describing their attitude toward borrowed capital, and factors potentially affecting the choice of funding sources. Thus, to check the proposed hypotheses, all classifying variables were excluded from the more than 200 indicators in the GEM database (including filters for the stage of the established business), together with variables that had no valid values. The list of indicators selected for analysis (except the classifying variable "Country" described above) is presented in Table 2.

The factors affecting early-stage entrepreneurs' choice of investment sources were determined using Fisher's linear discriminant analysis model (FLDA). This is a multidimensional statistical analysis technique that allows one to build a non-parametric predictive model of the discriminant function. Using 
certain attributes (such as the values of the control variables) this model allows one to verify whether or not the observed objects (in this case, early-stage entrepreneurs) belong to specific predetermined groups. The model's non-parametric nature allows one to apply the FLDA in its original form to distribute objects or events between previously defined groups [Fisher, 1936; McLachlan, 2004]. In a two-dimensional characteristic space, the separating surface is a direct line, building the discriminant function $d$, which describes the required surface separating the specified classes on the basis of the values of the predictor variables, would serve as the core of the discriminant analysis. The function has the following form:

$d=b_{1} \times x_{1}+b_{2} \times x_{2}+\ldots+b_{n} \times x_{3}+a$

where: $x_{1}, x_{2}, \ldots, x_{n}$ are values of the variables corresponding to the units in question;

$b_{1}, b_{2}, \ldots, b_{n}$ are the coefficients measured by the FLDA model; and

$a$ is a constant.

According to the general FLDA concept, the discriminant function was built upon the basis of the values of predictor variables describing the set of observed objects whose membership in specific groups is known ("training sample"). Then the model was verified using a control sample. In our case, a stratified sliding control was applied for verification, which allowed us to reduce the dispersion of the final assessments and build more stable and reliable predictive models [McLachlan, 2004; Efron, 1988]. The resulting discriminant function (sufficiently stable and adequately predictive) allowed us to include previously unclassified individuals in specific groups. We analyzed two groups of respondents: those choosing between their own and borrowed resources as the funding source for their business. A single discriminant function can be built in this case. Based on its calculated values (the so-called discriminant scores), the probability of unclassified objects' belonging to one or another group is determined [Bühl, Zöfer, 2001; Nasledov, 2011]. The quality of the discriminant function was tested using Wilks' Lambda $\left(\lambda_{\mathrm{w}}\right)$, which describes the share of function value dispersion not due to the differences between the respondent groups. The closer $\lambda$ w's value is to zero, the larger the difference between the average values, and accordingly, the higher is this variable's importance for determining the difference between the earlystage entrepreneur groups in question. The significance of the identified differences between the average values for the groups ( $\mathrm{p}$-value $<0.05)$ confirmed that they were not random. The predictive potential of the constructed models was measured by the share of units in the control sample whose membership in a specific group was predicted accurately. It was measured using the accuracy rate (AR), true positive rate (TPR), true negative rate (TNR), and predictability indicators [Fawcett, 2006; Powers, 2011]. The FLDA model-based analysis was conducted in several stages:

- Splitting the array of microdata by the "Country" variable which had seven values (to build a model predicting early-stage entrepreneurs' choice of funding source in specific national contexts)

- Testing the significance of the differences between the predictor variables' values determined for their the two respondent groups (those opting for their own or borrowed resources)

- Building country-specific models distinguishing between specific features of the units being classified, which determine the respondents' membership in one of the two above groups

- Assessing the significance, quality, and predictive potential of the models

- Conducting a comparative analysis of the statistical structure of the constructed models; checking the hypotheses and comparing the various factors' impact on early-stage entrepreneurs' choice of funding sources in different countries in specific national contexts.

The calculations were made using the SPSS-19 software package.

\section{Results of modeling early-stage entrepreneurs' financial choices}

After splitting the prepared microdata matrix on the basis of the national context, differences between the average values of the expected predictors for the two early-stage entrepreneur groups (those opting for their own or borrowed financial resources) were assessed for each of the seven country subsets. The aggregated results of testing the differences between the countries and indicators with significant mismatches between these groups are presented in Table 3 .

Variables, for which there are differences between the group average values for specific countries, were not random with a probability close to 1 (p-value $<0.05$ ). These factors affect early-stage entrepreneurs' choice of funding sources in the corresponding countries. For each controlled variable, the $\lambda w$ value does not indicate a statistically significant contribution of relevant differences between the groups to the overall dispersion of the discriminant function's scores. An international comparison of the statistical structure of the sets of variables, which significantly differ between the respondent groups, confirms that the national socioeconomic context does indeed define specific factors (their mix and variety) affecting 


\section{Table 3. Results of the group mean values equality test}

\begin{tabular}{|c|c|c|c|c|c|c|c|c|c|c|}
\hline \multirow{2}{*}{ Countries } & \multirow{2}{*}{ Indicator } & \multicolumn{9}{|c|}{ Predictor } \\
\hline & & 1 & 2 & 3 & 4 & 5 & 6 & 7 & 8 & 9 \\
\hline \multirow{2}{*}{ Russia } & $\lambda w$ & & & & & & & & 0.846 & \\
\hline & $\mathrm{p}$-value & & & & & & & & 0.020 & \\
\hline \multirow{2}{*}{ Hungary } & $\lambda w$ & & & 0.920 & & & & & & \\
\hline & $\mathrm{p}$-value & & & 0.004 & & & & & & \\
\hline \multirow{2}{*}{ Romania } & $\lambda w$ & & & & & 0.636 & & & & 0.497 \\
\hline & $\mathrm{p}$-value & & & & & 0.002 & & & & 0.007 \\
\hline \multirow{2}{*}{ Latvia } & $\lambda w$ & & & & & & 0.926 & & 0.960 & \\
\hline & p-value & & & & & & 0.016 & & 0.035 & \\
\hline \multirow{2}{*}{ Croatia } & $\lambda w$ & & 0.854 & & & & 0.800 & & & 0.936 \\
\hline & $\mathrm{p}$-value & & 0.006 & & & & 0.002 & & & 0.037 \\
\hline \multirow{2}{*}{ Slovenia } & $\lambda w$ & & & & & 0.891 & & & & \\
\hline & p-value & & & & & 0.002 & & & & \\
\hline \multirow{2}{*}{ Bosnia and Herzegovina } & $\lambda w$ & 0.893 & & & 0.731 & & 0.639 & 0.675 & & 0.789 \\
\hline & & 0.001 & & & 0.000 & & 0.000 & 0.000 & & 0.000 \\
\hline
\end{tabular}

Predictors:

1 - Shut down one's business during the previous year, and never restarted the enterprise

2 - Expectation to start a new business over the next three years

3 - Know somebody personally who started a business over the last two years

4 - People who start their own business have a high level of status and respect

5 - Regular coverage about successful new businesses in the media

6 - Offering a product (service) that is new or unfamiliar to customers

7 - Starting one's own business as a desirable career choice

8 - Expect favourable conditions for starting one's own business to be in place in the area of residence over the next six months

9 - Fear of failure or lack of competencies as barriers to starting one's own business

Source: calculated by the authors.

financial choices. This means that, in transitional economies, none of the predictors noted in the literature affect early entrepreneurs' financial choice. Therefore, we must identify latent factors manifesting as country-specific combinations of the controlled variables. Thus, our first hypothesis is confirmed.

At the next stage, discriminant function models were built for Russia and CEE countries, which allowed for predicting early entrepreneurs' choice of funding sources in the socioeconomic context of their country of residence. All the constructed models were significant; the normalized discriminant function predictors' coefficients allowed us to establish the direction and estimate the force of the corresponding predictor's impact on the financial choice of the early entrepreneurs, and therefore interpret the model (Table 4).

In the end, the factors increasing the probability of early-stage entrepreneurs opting for the use of borrowed resources were identified for each country:

Russia: there are expectations that in the next six months conditions for starting one's own business will improve (and if the prospects for business conditions are perceived negatively, the above probability

\section{Table 4. Normalized coefficients and significance of the discriminant functions}

\begin{tabular}{|c|c|c|c|}
\hline No. & Country & Fisher's linear discriminant ${ }^{*}$ & p-value \\
\hline 1 & Slovenia & OwnF_BorrF $=-2.314+3.928 \cdot$ NBMEDI & 0.002 \\
\hline 2 & Hungary & OwnF_BorrF $=-2.657+4.388 \cdot \mathrm{KNOWEN}$ & 0.004 \\
\hline 3 & Russia & OwnF_BorrF $=-0.922+1.428 \cdot$ OPPORT & 0.020 \\
\hline 4 & Romania & OwnF_BorrF $=-2.347+3.804 \cdot$ FRFAIL+ 1.391·NBMEDI & 0.000 \\
\hline 5 & Latvia & OwnF_BorrF $=-5.530+4.118 \cdot$ SUNEWCST $+1.438 \cdot$ OPPORT & 0.016 \\
\hline 6 & Croatia & OwnF_BorrF $=-11.310+6.822 \cdot S U N E W C S T+4.597 \cdot F U T S U P+1.786 \cdot F R F A I L$ & 0.002 \\
\hline 7 & $\begin{array}{l}\text { Bosnia and } \\
\text { Herzegovina }\end{array}$ & $\begin{array}{l}\text { OwnF BorrF }=-9.469+5.155 \cdot \text { DISCEN }+4.116 \cdot \text { SUNEWCST }+3.302 \cdot \text { FRFAIL + } \\
+3.298 \cdot \text { NBSTAT }+2.547 \cdot \text { NBGOOD }\end{array}$ & 0.000 \\
\hline
\end{tabular}

* Country models in the table are sorted first by complexity of the discriminant's statistical structure (in ascending order), and then by significance of the discriminant function (in descending order).

Source: calculated by the authors. 
Table 5. Quality of CEE transitional economies' early-stage entrepreneurs' classifications based on the FLDA models

\begin{tabular}{|l|c|c|c|}
\hline \multicolumn{1}{|c|}{ Country } & $\begin{array}{c}\text { Accuracy } \\
\text { (AR - share of correctly } \\
\text { classified observations in the } \\
\text { population, \%) }\end{array}$ & $\begin{array}{c}\text { Sensibility, a } \\
\text { (TPR - share of truly positive } \\
\text { classification results in the } \\
\text { population, \%) }\end{array}$ & $\begin{array}{c}\text { Specificity, } \boldsymbol{\beta} \\
\text { (TNR - share of truly negative } \\
\text { classification results in the } \\
\text { population, \%) }\end{array}$ \\
\hline Russia & 61.5 & 9.02 & 52.46 \\
\hline Hungary & 58.9 & 8.93 & 12.3 \\
\hline Romania & 51.9 & 30.23 & 39.86 \\
\hline Latvia & 59.5 & 38.26 & 29.35 \\
\hline Croatia & 69.4 & 9.27 & 31.29 \\
\hline Slovenia & 57.7 & 39.23 & 48.41 \\
\hline $\begin{array}{l}\text { Bosnia and } \\
\text { Herzegovina }\end{array}$ & 70.1 & 31.54 \\
\hline Source: calculated by the authors. & & & 37 \\
\hline
\end{tabular}

drops practically to zero). The same applies to Latvia, where plans to implement an innovative business idea and supply products or services that are new to the market can serve as an additional incentive.

Hungary: there is active involvement of potential businessmen in the social networks of entrepreneurs who have started their own firm over the previous two years.

Slovenia: a positive image of entrepreneurship is promoted by the local media, which regularly covers success stories of new business projects. The same factor also applies in the case of Romania, and its impact outweighs the fears of possible business failure.

Croatia: entrepreneurs have plans to start an innovative business over the next three years, despite the risk of failure. Consumers' intentions make the biggest contribution to the discriminant function.

Bosnia and Herzegovina: five combined factors affect early-stage entrepreneurs' financial choices here. The primary one is having had the experience of liquidating a business over the last year. The probability under consideration also increases if people, who have successfully started a new business, enjoy increasing public recognition and acquire a high social status, while society becomes convinced that entrepreneurship is a desirable career choice. Finally, the willingness to launch, despite the risk of failure, the production of innovative goods or services previously absent on the market also plays a positive role. In other words, Hypotheses 2-4, which imply a positive correlation between the relevant factors and early-stage entrepreneurs' choice in favor of borrowed funding, turned out to be correct in the following cases:

- Hypothesis 2 (favorable conditions for starting one's own business): in Russia and Latvia

- Hypothesis 3 (an innovative business idea): in Latvia, Croatia, and Bosnia and Herzegovina; note that in the two latter cases this factor's impact outweighs fears of possible failure;

- Hypothesis 4 (the promotion of a positive image of entrepreneurship in the media): in Slovenia and Romania.

The predictive potential of the constructed country-specific discriminant models, i.e. their ability to break early-stage entrepreneurs down into those willing and those unwilling to use borrowed money on the basis of the canonical functions, was measured on the basis of the following integral characteristics (Table 5).

As we see, the models' diagnostic efficiency is quite high, though their sensitivity is significantly lower than their specificity. Therefore, the suggested models should be used as discriminators, i.e., tests for identifying early-stage entrepreneurs who prefer to fund their businesses with their own resources.

The prognostic value of the constructed models is limited by the predominance of one's own funds (including "love capital") in early-stage entrepreneurs' portfolio (Table 5). Therefore, the more specific the model, the higher the prognostic value possessed by the positive results (i.e., the probability that the early-stage entrepreneur's predicted willingness to use borrowed capital turns out to be actually true). However, since the prevalence of a phenomenon affects the model's predictive value, the positive results obtained even for a highly specific discriminator, given the low share of borrowed resources in earlystage entrepreneurs' capital structure, can be perceived as a false positive.

Given the stated objective of the study, the results appear quite satisfactory. All hypotheses were confirmed in one national context or another, which is important from the point of view of developing specific approaches to the promotion and support of entrepreneurship. Furthermore, the prognostic value of the models turned out to be sufficiently high. 


\section{Table 6. Prognostic value of the classification models based on the constructed discriminant functions}

\begin{tabular}{|l|c|c|}
\hline Country & $\begin{array}{c}\text { Prognostic value of positive results (the share of } \\
\text { truly positive results in the total number of positive } \\
\text { classification results, \%) }\end{array}$ & $\begin{array}{c}\text { Prognostic value of negative results (the share of } \\
\text { truly negative results in the total number of negative } \\
\text { classification results, \%) }\end{array}$ \\
\hline Russia & 57.89 & 62.14 \\
\hline Hungary & 36.47 & 66.03 \\
\hline Romania & 65.71 & 48.68 \\
\hline Latvia & 59.09 & 60.32 \\
\hline Croatia & 75.0 & 64.29 \\
\hline Slovenia & 50.0 & 59.31 \\
\hline $\begin{array}{l}\text { Bosnia and } \\
\text { Herzegovina }\end{array}$ & 78.46 & 63.08 \\
\hline Source: calculated by the authors. & \\
\hline
\end{tabular}

\section{Conclusions and recommendations}

In each country, the transitional economy is unique, with specific characteristics and conditions that affect the development path and drivers of entrepreneurship. These in turn determine early-stage entrepreneurs' attitude towards various funding sources. Therefore, the same measures aimed at supporting entrepreneurship can cause different reactions by the target communities depending on the country-specific context.

The situation with the structure of early-stage entrepreneurs' financial capital is particularly critical: the inclination to avoid official loans slows down the development of entrepreneurship in Russia, while the availability of "love capital" only aggravates the problem. At the same time, the simple duplication of entrepreneurship support arrangements that were successfully implemented in other countries and regions may have undesirable negative effects in the Russian economic environment. Specific features of entrepreneurial practices in the country must be carefully taken into account, based on published statistics and special population surveys of entrepreneurial activities. Providing information support to the designers of entrepreneurship promotion policies would help them suggest specific steps to increase the efficiency of funding programs for early-stage entrepreneurship.

The legal environment for entrepreneurship needs to be stabilized, made more transparent and comfortable in terms of new entrepreneurs' prospects; business support should be individualized, especially at the early stages (until companies reach three and half years of operation). This would help all early-stage entrepreneurs feel protected, and assess their business prospects as favorable.

Keeping in mind the results obtained for transitional economies, improving Russia's business climate should first of all involve promoting innovative entrepreneurial behavior among the general population. Relevant tools may include idea fairs, exhibitions of innovative products, and consumers' suggestions (the municipal and local authorities seem to be best suited for the task of analyzing and presenting these proposals). The promotion of innovation could help early-stage entrepreneurs overcome the fear of failure, a lack of self-confidence, and the negative experiences of previous business failures.

Finally, mass media could and should provide effective information support to early-stage entrepreneurs, and help them find their way in the relevant environment. Promoting a new, positive image of entrepreneurship in the public conscience, presenting (and helping people see) it as a desirable career choice could extend the range of factors prompting early-stage entrepreneurs to optimize the financial structure of their capital.

Generally, the results of our analysis suggest the possibility of applying individual approaches to designing entrepreneurship support policies in Russia and CEE countries. Optimizing early-stage entrepreneurs' funding choices (including when they are faced with expensive loans), and increasing the appeal of borrowed financial resources would help promote the development of the entrepreneurial sector, and make it more innovative. 


\section{References}

Aidis R. (2005) Entrepreneurship in transition countries: A review (UCL School of Slavonic and East European Studies Working Paper no 61, December), London: University College London.

Antoniou A., Guney Y., Paudyal K. (2008) The Determinants of Capital Structure: Capital Market-oriented versus Bank-oriented Institutions. Journal of Financial and Quantitative Analysis, vol. 43, no 1, pp. 59-92.

Audretsch D., Thurik R. (2004) A Model of the Entrepreneurial Economy. International Journal of Entrepreneurship Education, vol. 2, no 2, pp. 143-166.

Beck T., Demirguc-Kunt A., Maksimovic V. (2008) Financing Patterns around the World: Are Small Firms Different? Journal of Financial Economics, vol. 89, no 3, pp. 467-487.

Berger A., Christa H.S., Bouwman T.K., Schaeck K. (2010) Bank liquidity creation and risk taking during distress (Discussion Paper Series 2, no 05/2010), Berlin: Deutsche Bundesbank.

Black L.K. (2009) Information Asymmetries between Lenders and the Availability of Competitive Outside Offers. Paper presented at the Workshop on Entrepreneurial Finance hosted by the Federal Reserve Bank of Cleveland and Kauffman Foundation, Cleveland, OH, March 2009.

Bühl A., Zöfel P. (2001) SPSS version 10. Einführung in die modern Datenanalyse unter Windows. München: Pearson Education Deutschland GmbH.

Chavis L., Klapper L., Love I. (2011) The Impact of the Business Environment on Young Firm Financing. The World Bank Economic Review, vol. 25, no 3, pp. 486-507.

Djankov S., Murrell P. (2002) Enterprise Restructuring in Transition: A Quantitative Survey. Journal of Economic Literature, vol. 40, no 3, pp. 739-793.

Efron B. (1988) Netraditsionnye metody mnogomernogo statisticheskogo analiza [Non-traditional methods of multivariate statistical analysis], Moscow: Finansy i statistika (in Russian).

Fawcett T. (2006) An Introduction to ROC Analysis. Pattern Recognition Letters, vol. 27, no 8, pp. 861-874. DOI:10.1016/j.patrec.2005.10.010.

Fisher R.A. (1936) The use of multiple measurements in taxonomic problems. Annals of Eugenics, vol. 7, pp. $179-188$.

GERA (2017) GEM Global Report 2016/17, London: Global Entrepreneurship Research Association.

Gerasimova S.M. (2012) Empiricheskie issledovaniya struktury kapitala kompanii na razvivayushchikhsya rynkakh: spetsifika i metodologiya [Empirical Investigations of the Capital Structure of Companies in Emerging Markets: Specificity and Methodology]. Korporativnye finansy [Journal of Corporate Finance Research], vol. 6, no 1, pp. 97-109 (in Russian).

Glas M., Drnovsek M., Mirtic D. (2000) Problems faced by new entrepreneurs: Slovenia and Croatia - A Comparison. Paper presented at the 30th ESBS Seminar, Gent.

Hashi I. (2001) Financial and Institutional Barriers to SME Growth in Albania: Results of an Enterprise Survey. MOST, vol. 11, pp. 221-238.

Holm S. (1979) A simple sequentially rejective multiple test procedure. Scandinavian Journal of Statistics, vol. 6, no 2, pp. 65-70.

Klapper L., Laeven L., Rajan R. (2006) Barriers to Entrepreneurship. Journal of Financial Economics, vol. 82, no 3, pp. 591-629.

Levine R. (2005) Finance and Growth: Theory and Evidence. Handbook of Economic Growth (eds. P. Aghion, S. Durlauf), Amsterdam: Elsevier, pp. 865-934.

McLachlan G.J. (2004) Discriminant Analysis and Statistical Pattern Recognition, Hoboken, NJ: Wiley Interscience.

Murzacheva E. (2011) The input of informal capital into the entrepreneurial activity in the international context. Theory of Entrepreneurship: New Results and Prospects (Research papers) (ed. A. Chepurenko), Moscow: HSE Publishing, pp. 103-135.

Murzacheva E.I., Obraztsova O.I. (2008) Neformal'nye investory kak osnovnye sponsory rossiiskogo narozhdayushchegosya predprinimatel'stva: vybor v usloviyakh dorogogo kredita [Informal investors as the main sponsors of Russian nascent entrepreneurship: Choice under conditions of an expensive loan]. Finansy $i$ biznes [Finance and Business], no 3, pp. 145-153 (in Russian).

Nasledov A. (2011) SPSS 19: Professional'nyi statisticheskii analiz dannykh [SPSS 19: Professional statistical analysis of data], SPb.: 'Piter' (in Russian).

Obraztsova O.I. (2010) GEM kak istochnik al'ternativnoi statistiki dlya sravnitel'nogo mezhstranovogo analiza predprinimatel'skoi aktivnosti [GEM as a source of alternative statistics for a comparative cross-country analysis of entrepreneurial activity]. Teoriya predprinimatel'stva $v$ Rossii. Po materialam Global'nogo monitoringa predprinimatel'stva [Theory of Entrepreneurship in Russia. On the basis of the Global Monitoring of Entrepreneurship] (eds. T.A. Alimova, O.I. Obraztsova, A.Yu. Chepurenko), Moscow: HSE Publishing, pp. 18-62 (in Russian).

Powers D.M.W. (2011) Evaluation: From Precision, Recall and F-Measure to ROC, Informedness, Markedness \& Correlation. Journal of Machine Learning Technologies, vol. 2, no 1, pp. 37-63.

Reynolds P., Bosma N., Autio E. (2005) Global Entrepreneurship Monitor: Data Collection Design and Implementation 1998-2003. Small Business Economics, vol. 24, no 3, pp. 205-231.

Robb A., Robinson D. (2010) The Capital Structure Decisions of New Firms (NBER Working Paper no 16272), Cambridge, MA: National Bureau of Economic Research.

Shane S., Venkataraman S. (2000) The Promise of Entrepreneurship as a Field of Research. The Academy of Management Review, vol. 25, no 1, pp. 217-226.

Verheul I., Thurik R. (2001) Start-Up Capital: Does Gender Matter? Small Business Economics, vol. 16, no 4, pp. 29-45.

Welter F. (2011) Contextualizing Entrepreneurship - Conceptual Challenges and Ways Forward. Entrepreneurship Theory and Practice, vol. 35, no 1, pp. 165-184.

Welter F., Smallbone D. (2011) Institutional Perspectives on Entrepreneurial Behavior in Challenging Environments. Journal of Small Business Management, vol. 49, no 1, pp. 107-125.

Yang J.S., Kuntchev V., Ramalho R., Rodriguez-Meza J. (2013) What have we learned from the Enterprise Surveys regarding access to finance by SMEs? Policy Research Working Paper WPS6670. Washington, D.C.: World Bank. 


\section{INNOVATION IN COMPANIES}

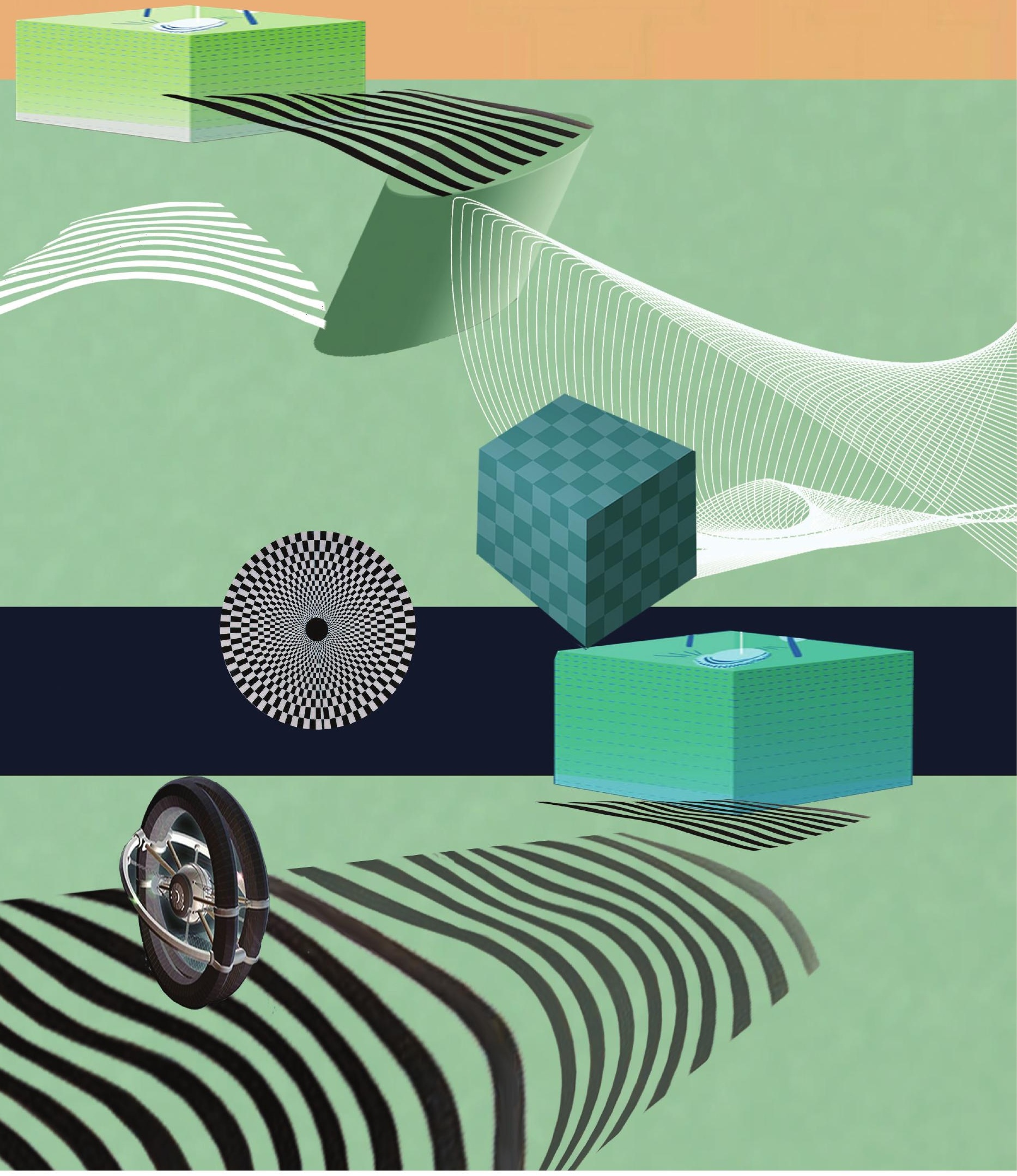




\title{
Suboptimal Size: Factors Preventing the Growth of Russian Small and Medium-Sized Enterprises
}

\author{
Victoria Golikova \\ Leading Research Fellow, Institute for Industrial and Market Studies, victoria@hse.ru
}

Boris Kuznetsov

Professor, Faculty of Economic Sciences; Leading Research Fellow, Institute for Industrial and Market Studies, bkuznetsov@hse.ru

National Research University Higher School of Economics, 20, Myasnitskaya str., Moscow 101000, Russian Federation.

\begin{abstract}
$\mathrm{T}$ The Russian manufacturing sector has an underdeveloped SME sector both in terms of employment and contributions to GDP in comparison with other economies, with evident signs of stagnation over the past few decades. However, little is known about the capacity of SME sector, i.e., the opportunities to grow and thus exploit the benefits reaped from economies of scale. This paper attempts to estimate the impact of internal and external factors on a firm's competitiveness in the context of optimal enterprise size.

The main conclusion is that that the satisfaction of Russian SME managers has been increasing due to factors such as the sufficient supply of qualified personnel, modern infrastructure, developed partnerships, the expansion

of the geographical scope of available markets and favorable institutional conditions for entrepreneurship. In contrast, serious constraints to SME growth in Russia discourage entrepreneurs and lead to poor decisions by managers such as exploiting shadow schemes, leaving the market or growth in the form of nominally independent firms under the informal "umbrella" of one owner. Formidable bureaucratic barriers and significant transactional costs increase the vulnerability of small businesses to administrative pressure. In order to survive and remain on the market, Russian companies have to adapt to the existing institutional environment, and must be larger compared to their counterparts in developed economies.
\end{abstract}

Keywords:

small and medium enterprises;

scale of business;

determinants of growth;

barriers to growth;

Russia.

Citation: Golikova V., Kuznetsov B. (2017) Suboptimal Size: Factors Preventing the Growth of Russian Small and Medium-Sized Enterprises. Foresight and STI Governance, vol. 11, no 3, pp. 83-93. DOI: 10.17323/25002597.2017.3.83.93 
I thas been empirically demonstrated that increasing the size of existing firms provides a major impetus for economic growth. For example, in [Rajan, Zingales, 1998] it was shown that for a sample of 43 countries, about two thirds of economic growth in terms of output was attributable to an increase in the size of firms, while the remaining one third came from the establishment of the new businesses. Therefore, over the past several decades, economic research has focused on the barriers impeding the growth of firms, which prevents the firms from reaching the "optimal" scale. On the other hand, this "optimal" scale ${ }^{1}$ may be very different depending on the industry and the specific sales market: the specifics of the produced goods, the size of this market, the structure of the market (concentration, network development), etc. Two different processes may lead to optimal scale: growth (mainly for young, small firms experimenting on the market) or on the contrary, downsizing, if a firm has become too large and difficult to manage.

The process of downsizing and restructuring Russias manufacturing sector took place in the early 1990-s during the transition to a market economy which continued into the mid-2000s and has been the focus of vast empirical research [Linz, Krueger, 1998; Djankov, 1999; Filatotchev et al., 2000; Estrin et al., 2001; Ahrend, 2006; Bhaumik, Estrin, 2007, among others]. During this period, the consequences of the search for "optimal" scale were to a large extent more often seen in the growth of young firms than in the downsizing of large former Soviet manufacturing giants.

Small business mangers consider optimal scale to be the difference between "actual and intended size" [Hermans et al., 2012, p. 12]. Such a multi-dimensional construct is the outcome of entrepreneurs' goals, the firm's strategic orientation, the evaluation of available resources to meet current market demand and benchmarking with competitors. In some sense, the views of optimal scale fall in line with the perception of a firm's success on the market, i.e., an indirect evaluation of the firm's current competitiveness and its sustainable position on the market. The managers of many firms are dissatisfied with their current scale of production [Weber et al., 2015]. On the one hand, this group includes quite successful firms that have not yet reached a desirable scale but intend to proceed in growing their business and exploit market opportunities. A strategic focus on high growth characterizes the best of entrepreneurial society [Autio et al., 2011]. On the other hand, directors' complaints about the inadequate scale of production may be an inherent feature of firms that wished to grow but failed in their competition with more productive companies. Due to such failure, they are likely to eventually leave the market.

In this paper, we will attempt to shed light on what determines the perceptions of scale of the managers of small and medium enterprises (SMEs), taking into account real performance and competitiveness.

Beside the internal, firm-specific features that may impact the opportunities for reaching an optimal size, we also consider the characteristics of the regional institutional environment that shapes the opportunities or constraints given to firm performance. In transitioning economies, the institutional environment often leads to an imbalance, facilitating the success of large firms while it restricts the opportunities for small and medium businesses. Moreover, empirical evidence from cross-country analyses calls attention to institutional deficiencies on the country level (weak intellectual property rights protection and corruption, etc.), which have a substantial negative impact on young firms aspirations for growth and development [Estrin et al., 2013]. In the case of Russia, the significant inter-regional diversity of the business environment should be taken into account as even neighboring regions can differ greatly regarding the conditions for doing business [EBRD, 2013; Bruno et al., 2008; Iwasaki et al., 2016].

\section{Determinants and patterns of SME growth: the Russian context}

A common feature of the countries with less successful transitions to market economies is the stagnation of their SME sector. In Russia, according to official statistics [Rosstat, 2014], the share of employment in this sector (25\%) and its contribution to GNP (21\%) are marginal and among the lowest compared to other countries. Since the market liberalization of the 1990s, entrepreneurship has failed to play a significant role in the Russian economy [Chepurenko, 2012], despite its potential to become one of the chief drivers of both economic growth and democracy in Russia [Richter, Schaffer, 1996]. The entrepreneurial dynamism, which is fundamental to innovation and growth according to the endogenous growth theory [Aghion, Howitt, 1997], simply has not yet been achieved in Russia. Small businesses remain too small and lack the sufficient scale to be truly competitive [Estrin et al., 2006; Peng, 2001; Puffer et al., 2010]. Furthermore, in 2012-2014 the share of players who had no growth aspirations, i.e., those did not plan to create jobs, increased significantly. ${ }^{2}$ This situation is confirmed by the conclusions of a mounting body of research on entrepreneurship in emerging economies [Manev, Manolova, 2010; Ojala, Isomaki, 2011]. However, in contrast to SMEs in developed economies, which face challenges mainly in achieving high rates of growth [Lee, 2014; Mason, Brown, 2013], the SMEs in transitioning economies, especially in Russia, struggle to grow at all [OECD, 2015; Welter, Smallbone, 2011; Smallbone et al., 2014]. Moreover, keeping in mind that this sector, especially as far as manufacturing is concerned, is heterogeneous and consists of quite a diverse population of firms - new entrepreneurial firms vs. former Soviet enterprises [Chepurenko, 2015] — we

\footnotetext{
${ }^{1}$ We consider the optimal scale a firm's competitive position in terms of its size and cost levels [Bennet, Levinthal, 2017]. Optimal scale is a consequence of a firm's growth.

${ }^{2}$ http://www.gemconsortium.org/country-profile/104
} 
might expect quite different patterns in their development as regards growth, downsizing or stagnation. This means that the Russian SME sector is not quite synonymous with the entrepreneurial sector and this point is important in understanding perceptions concerning the scale of production.

One must distinguish between the initial and mature stages of the life cycles of SMEs. Acs and Audretch [Acs, Audretch, 2001] noted that the opportunity to grow and survive in post-entry period is determined by the difference between the minimum efficient size (MES) and the actual size of the firm. This is the main motivation for growth among the entrants. Empirical evidence from developed countries suggest that firms follow an "up-or-out" dynamic where small firms are more likely to go bankrupt than larger firms, but in the case of success, the chances for growth rise [Bartelsman et al., 2013; Navaretti et al., 2014; Geurts, van Biesebroeck, 2016, etc.]. In general, the average size of a firm will double after 5-10 years on the market, but only fifty percent of entrants will survive [Geurts, van Biesebroeck, 2016]. This is how the mechanism of allocative efficiency works in developed market economies. A similar trend was found in the developing economies of Eastern Europe where there was very low or even negative allocative efficiency at the beginning of the transition period and only later did it improve significantly [Bartelsman et al., 2013].

In contrast, there are still no clear indications of improving allocative efficiency in Russia. The specific problem facing Russia's economy is the extreme volatility of the economy. In periods of long and deep slumps, new and efficient companies are given fewer chances to survive than older firms that face less intense competition. So, they leave the market before they achieve the minimum efficient size. The inefficient incumbents "hold onto resources that more efficient firms could use if they were freed up" [González et al., 2013]. In the Russian case, it is more likely to find these "holders of resources" among large former Soviet manufacturing firms that can be quite happy about their scale of production though they are less productive and by remaining on the market they continue to constrain the Schumpeterian process of "creative destruction" 3 . As Hsieh and Klenow [Hsieh, Klenow, 2009] recently documented, in less developed economies, production factors are often concentrated within unproductive firms while new entrants suffer from limited access to foreign resources, capital, and technologies, while at the same time they face poor infrastructure and political instability. As a result, small firms' growth is slowed, medium enterprises are practically absent (the phenomenon of the "missing middle") and the few large firms enjoy preferential treatment, dominate policies, block competitors' access to the market, and have special relationships with the government and banks [Tybout, 2000].

"Learning-by-doing" models, in our opinion, most fittingly illustrate firms' growth behavior and the perception of adequate scale. This approach was initially considered within the framework of the concepts of passive learning [Jovanovic, 1982] and active learning [Ericson, Pakes, 1995; Pakes, Ericson, 1998]. In the aforementioned works, the heterogeneity in growth among industrial producers was evaluated using a single index based on a costs/productivity ratio. ${ }^{4}$

Subsequently, in research on this issue, the impact of technological progress and specific factors of profitability on the balance of supply and demand began to be taken into consideration. Each aspect could follow separate and occasionally independent stochastic processes [Foster et al., 2012]. Supply side factors were not found to be primarily responsible for firms' heterogeneity in terms of growth and survival in developed economies. In less developed economies, financial constraints due to insufficient internal savings and strong discrimination against small firms on credit markets impede growth [Song et al., 2011] and should not be ignored. The same comment is relevant to capital adjustment costs that are important in some contexts [Foster et al., 2012] and to human capital resources [Ployhart, Moliterno, 2011]. We suppose that in developing economies such as Russia, supply-side determinants of growth, which are reflected in SME directors' perceptions of optimal scale, must be considered. One should consider such indicators as a firm's profitability, which gives one an idea of a firm's internal savings for growth, its access to external financial resources, the availability of qualified personnel and the quality of its fixed assets (equipment).

According to data from the U.S. Census of Manufacturers, which has been carried out since 1977 and contains 17,000 plant-year observations on production in physical units (and thus makes it possible to observe plants' output quantities and prices, not only total revenue) demonstrated that even on commoditylike product markets, the patterns of growth do not simply reflect productivity gaps, but rather show the differences in supply-side fundamentals [Foster et al., 2012]. This means that new businesses must lower prices today in the hope of stimulating demand for tomorrow. Calculations based on price elasticity using a model with depreciation show that a ten percent price cut will increase current sales by about 18 percent and current profit by eight percent. Accordingly, this increase in revenue will lead to a shift in the firm's demand

\footnotetext{
3 The reasons of their not leaving the market is beyond the scope of this paper.

${ }^{4}$ Jovanovic's passive learning [Jovanovic, 1982] explains the behavior of new firms that do not enter the market at an optimal size and gradually determine the level of their efficiency level by working on the market. Observations on realized profitability lead to one reconsidering their beliefs about their productivity and in accordance with said new beliefs, a firm either expands or contracts. For mature firms in the manufacturing sector, the concept of active learning [Pakes, Erikson, 1998] is most appropriate [Geurts, van Biesebroeck, 2016]. Manufacturing is characterized by higher entry costs and scale, and higher minimum efficient scale that those found in other industries [Geurts, van Biesebroeck, 2016]. Manufacturing firms at the moment of entry are more likely to have already gained knowledge about their efficiency and an idea of optimal scale of production. The model of active learning suggests that evaluating its own technology and market environment only high-productivity firms may find it profitable to make investments that will encourage future growth.
} 
over the following year by about four percent [Foster et al., 2012]. Thus, investments in relationship-specific capital - the increase of one's customer base, building a reputation among customers and strategic partners that could provide tacit knowledge [Street, Cameron, 2007; Hessels, Parker, 2013; Mohr et al., 2014; Rice et al., 2012], improving the quality of post-production services, etc. — are highly rewarded and help one achieve an optimal scale of production in the long run, but not immediately.

Most recent research draws attention to demand-side factors as entrepreneurs usually mention insufficient demand as one of key obstacles to their firms' growth [OPORA, 2016]. We capture demand-side factors by analyzing the features of a firm's markets and evaluating GRP per capita in the firm's local markets given that SMEs sell all or a substantial share of production on local markets. We assessed investments in relationshipspecific capital that might facilitate demand based upon the availability of strategic partnerships with local and foreign firms that were established two to three years prior to the conduct of the survey.

The aforementioned determinants, both demand and supply side, are relevant for all countries, however, in transitioning economies, their impact on growth and sometimes the vector of a business's development is determined by the features of the institutional environment. The body of empirical research on SME performance in developing economies found a robust relationship between firm performance and the quality of institutions [Aidis et al., 2008; Molz et al., 2009; Blagojevic, Damijan, 2013; Sharafutdinova, Kisunko, 2014; Yukhanaev et al., 2015; Volchek et al., 2013a,b; Wang, You, 2012; Krasniki, Desai, 2016; Welter, Smallbone, 2011]. However, the mechanism behind their interactions remains poorly studied. An analysis of institutions is of paramount importance in the study of emerging economies where formal institutions are often ineffective arbiters for competitive markets and structurally unable to foster a business-friendly environment [Hoskisson et al., 2011]. Economies that did not manage to develop according to the Western model must operate under an alternative informal institutional network [Smallbone, Welter, 2010], which is prone to rent-seeking, shadow schemes and similarly, tends to incentivize sub-optimal behavior among firms [Golikova, Ermilova, 2006; Sharafutdinova, Kisunko, 2014]. As a result, a discussion of a firm's aspirations for growth, scale of production and performance in transitioning economies without recourse to a study of institutional issues is liable to be incomplete [Aidis et al., 2008; Aidis, 2015; Welter, Smallbone, 2011; Smallbone et al., 2014; Krasniki, Desai, 2016; Wang, You, 2012]. Moreover, an institution-based study has become the main theoretical framework for business research on emerging economies and researchers tend to explore the interplay of formal and informal institutions at multiple levels of analysis [Thorsten et al., 2005; Meyer, Peng, 2005, 2016; Estrin et al., 2013]. In our research, we are mostly interested how the institutional environment, assessed by the level of regional corruption, determines the perceptions of firms concerning optimal scale. This will be studied with account of the different age cohorts, i.e., a consideration of the life cycle of the studied businesses with special attention given to new firms [Acs, Armington, 2004].

The determinants of firm growth described above, such as supply- and demand-side factors, are still valid for firms operating within emerging economies. However, their effectiveness and the direction of their effect is often determined by the idiosyncrasies of the institutional environment [Marcelin, Mathur, 2015; Cuaresma et al., 2013; Volchek et al., 2013a,b; Molz et al., 2009; Dallago, 2000; Blagojevic, Damijan, 2013; Welter, Smallbone, 2011; Yukhanaev et al., 2015].

\section{Perceptions of optimal scale: European vs. Russian firms}

One of the possible approaches to select firms with sub-optimal sizes is to ask the firms' CEOs. It should be stressed that this indicator is more about the perceptions than about the "objective" difference between the desired and actual scale of their firm. Such perceptions may simply be a sign of general dissatisfaction with firm performance rather than a true assessment the inadequacy of scale per se. Nevertheless, this selfassessment allows us to pick up on firms that for some reason or another have not yet achieved or sustained a "comfortable" scale of activity. Either they are growing too slowly or are downsizing despite the initial intentions of the entrepreneurs. One must try to understand the external and internal factors affecting directors' attitudes about the unattainability of a desirable scale of production.

This approach was used in the EU-funded survey, European Firms in a Global Economy: Internal Policies for External Competitiveness (EFIGE). ${ }^{5}$ During this project, more than 14,000 manufacturing firms in seven EU countries were asked the following question: "Compared to your competitors, do you think that your firm's scale of production is adequate?" As the survey was conducted in 2010 and covered the period of the recent 2007-2009 crisis, when many firms had to downsize their business, it might be expected that firms, especially small ones, would more often complain about the insufficient scale of operations. Furthermore, there should be a great heterogeneity in their assessments across countries, industries, and size groups. However, contrary to expectations, the share of firms' owners/managers complaining about the scale of business was not very large in European countries (about 13\%) and the differences between countries, industries and size groups were not very significant ${ }^{6}$.

\footnotetext{
${ }^{5}$ Details on http://bruegel.org/efige/.

6 The relative outliers were Hungary (with a 22\% share of "complainers") and Austria (with only $8 \%$ ), which may have been due to the relatively small size of the economies and the relatively small sample sizes for those countries.
} 


\section{Figure 1. Dissatisfaction with the actual scale of operations: the share of firms by size groups} in seven EU countries and Russia

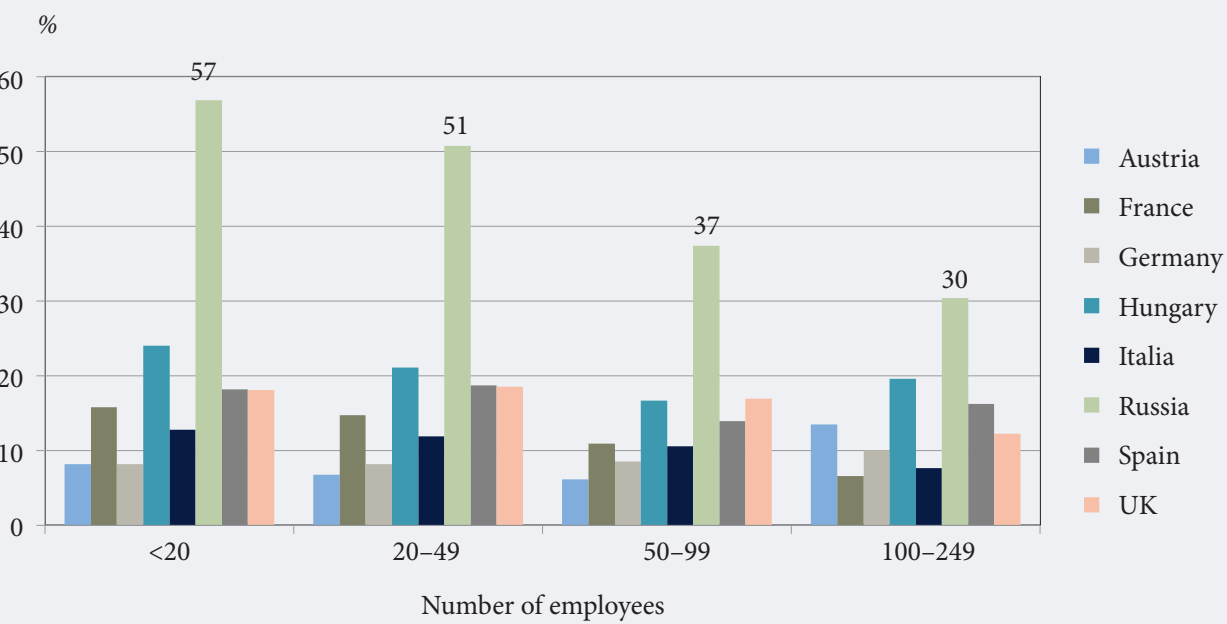

Source: compiled by the authors using EFIGE (2010) and RuFIGE (2014) survey data.

Five years later, a similar survey was conducted for Russian manufacturing firms ${ }^{7}$ with the same question included in the survey. This survey revealed a very different picture. The average share of Russian manufacturing firms dissatisfied with their scale of production was found to be $46 \%$ for the total sample and about $50 \%$ for SMEs (firms with fewer than 250 employees). In addition, there was great variety across size groups and industries: $32 \%$ of the firms with 100-250 employees complained about their scale of production, while for the group of the smallest firms (10-20 employees), the share of dissatisfied firms was much higher - 57\% (Figure 1). So, every second Russian manufacturing SME considers its scale of production insufficient for successfully competing on the market.

These results cannot be explained by differences in the actual size of firms in the Russian and EU manufacturing sectors in terms of employment. The mean number of employees at manufacturing SMEs in the 10-250 employee size group (weighted to control for sampling bias ${ }^{8}$ ) of all seven EU countries is 37.8 employees (varying from 42.7 in Germany to 32.4 in Italy) versus 42.4 employees in the Russian manufacturing SME sector. Nor can the results be explained by the age of firms (newly founded firms are expected to be smaller as they are still growing and have not yet reached their optimal scale): the share of firms under four years in the Russian and EU samples is approximately the same: about 7-9\%. According to our estimates, the huge gap between European and Russian firms is in median sales (2.584 million euros against 433,100 euros, respectively). This means that the scale of production of Russian SMEs is only $16.8 \%$ of their European counterparts.

\section{Data and Methodology}

The database we use was drawn from the RuFIGE (Russian Firms in the Global Economy) survey of 1,950 Russian manufacturing firms with at least 10 employees. The survey was conducted by GFK-Russia survey company in June-November 2014. The random structured sample was constructed in order to be representative in terms of distribution by industry and firm size. Face-to-face interviews with company directors using a semi-structured questionnaire were conducted in 60 Russian regions, though the sample was not representative by Russian regions. For this paper, we use a sub-sample of SME firms with 10249 employees (1,380 observations). The survey includes questions about the form of ownership, investments, innovation activity, other factors of production as well as assessments of the investment climate and the institutional environment. Another part of the original survey data consists of regional economic indicators from the official statistics and regional institutional indicators of INDEM. ${ }^{9}$

Using the described instruments, we evaluate the impact of different firm-specific features and regionalspecific institutional indicators on the probability of a firm being satisfied with the scale of operations while

\footnotetext{
The data used in this work was collected as a part of the research project "Russian Firms in a Global Environment" implemented within a framework of the Basic Research Program at the National Research University Higher School of Economics (HSE) in 2014-2015. For more details see: https://iims.hse.ru/rusfirms.

8 The weights were calculated in line with [Navaretti et al., 2010].

9 INDEM ("Information Science for Democracy") is a Russian NGO collecting data on various issues concerning corruption, justice, governance, political and regional issues, etc.
} 
controlling for industry and regional specifics and the individual characteristics of the firm. We assume that the answer to the question "Is the scale of your production adequate?" correlates with the latent variable of optimal ("adequate") scale. That is, if a firm complains about its scale of operations, there are some internal and/or external factors preventing it from either maintaining a reliable scale of production or from growing to an adequate size. Based on the reviewed literature, we are trying to verify three hypotheses:

H1: The failure to achieve an optimal scale of production may be due to negative supply side factors, i.e., a lack of resources, which leads to the relatively low quality of inputs and/or outputs.

The hypothesis is in line with the reviewed literature [Hermans et al., 2012] as well as with empirical evidence about the Russian manufacturing sector in general and the development of SMEs in particular: lack of access to and the high price of external finance, the deficit (and high cost) of qualified personnel and modern technologies, the relatively low levels of networking, communication and cooperation, etc.

H2: Firms have a sub-optimal scale due to unfavorable demand side factors, in particular, due to high transaction costs that create barriers impeding SMEs from entering new markets (in other regions and/or countries) and preventing firms from reaching an adequate size of operations.

The second hypothesis is based on the theory of heterogeneous firms [Melitz, 2003] and presumes that the higher the barriers of entry, the more important is companies' self-selection. In the case of Russia, such transaction costs include undeveloped market infrastructure including high transportation costs as well as the customs barriers for export operations. In other words, a firm is prevented from growing to the desired size because the market is not large enough.

H3: The firm is constrained in its growth or kept from maintaining optimal scale due to the unfavorable institutional environment in the region of operations. These constraints are more significant for relatively younger firms.

The hypothesis is based on empirical evidence concerning the significant differentiation of the institutional climate in the Russian regions [EBRD, 2013]. Those differences, first of all, include administrative pressure from the authorities, including the level of corruption. As demonstrated in the literature, an unfavorable business climate negatively impacts the process of creating SMEs, presumably by hindering firm growth.

\section{Model and Results}

In our research we used a simple probit model, where the satisfaction or dissatisfaction with the scale of business is a dependent dummy variable and different firm-specific, industry/market-specific, regionspecific factors are explanatory variables. The general formula is:

$$
\begin{aligned}
& \operatorname{Pr}\left(\text { Scale }_{i}\right)=\alpha 1\left(\text { Firm-performance indicators }_{i}\right)+\alpha 2\left(\text { Market-specific }_{i}\right)+\alpha 3(\text { Institutional indicators })+ \\
& +\alpha 4(\text { Regional_controls })+\alpha 5 \text { (Sectoral_controls })+\varepsilon
\end{aligned}
$$

The variables used it the model are described in the Table 1. The descriptive statistics for the total sample and for the two groups of SMEs (satisfied and unsatisfied with the scale of business) are reported in Table 2. We report the three models below. Model 1 includes Firm-specific indicators related, first, to the supply side limitations such as low sales margins, a lack of the qualified workers, restricted access to external finance and poor quality of equipment, which is measured by the share of equipment older than 10 years. Demand side restrictions are also taken into account. The proxy is a variable showing the scope of markets where a firm is selling its product - regional market only (base category), to other regions of Russia, or to other countries. The assessment indicators are controlled for age groups (as described above), the size of the firm (the logarithm of the number of employees) and for the type of sector (Pavitt classification). In Model 2, regional variables were added: Gross Regional Product per Capita and the Corruption Index (as a proxy for the regional quality of the institutional environment). In the last specification (Model 3), we included the cross-sectional data for age groups and the corruption index to check the hypothesis about how the impact of institutions depends upon the age of a firm. The errors are clustered by regions and we use weights calculated by using the general population structure to adjust for sample bias toward certain industries and size groups. The results for the three models are provided in Table 3.

We tested the results for robustness by including different additional factors such the position, age, and sex of the respondent, the family status of firm (whether or not the firm is owned by a family) ${ }^{10}$. All the results proved to be robust.

\section{Discussion}

We shall begin the discussion with our findings on the first hypothesis related to the supply side deficiencies. As we expected, the complaints about the insufficient scale of a business are strongly tied to low profitability.

\footnotetext{
${ }^{10}$ Besides for the check for robustness, such variables were used in the empirical research on the entrepreneurship to control for "the intentions" of firms [Kolvereid, 1992; Stenholm, Toivonen, 2009; Estrin et al., 2013].
} 


\section{Table 1. Variables of the probit model}

\begin{tabular}{|c|c|}
\hline Variable code & Description \\
\hline Scale & $\begin{array}{l}\text { Dependent dummy variable, a dummy equals } 1 \text { if a respondent says that the scale of business is adequate in } \\
\text { comparison with other competitors }\end{array}$ \\
\hline \multicolumn{2}{|r|}{ Firm-level characteristics } \\
\hline Deficit_qual_workers & $\begin{array}{l}\text { A dummy variable based on firms reporting a deficit of qualified workers as "a very serious problem": } 1 \text { - the } \\
\text { problem is very serious, } 0 \text { - it is not serious }\end{array}$ \\
\hline Margin & A dummy variable, which equals 1 if sales margin is above $2 \%, 0-$ if it is lower than $2 \%$ \\
\hline External_finance & A dummy variable, which equals 1 if a firm used banking loans in the period 2011-2013, 0 - if otherwise \\
\hline Old_equipment_share & A quantitative indicator of the share of production equipment 10 years or older \\
\hline Age_of_firm & $\begin{array}{l}\text { Categorical variable: } 1 \text { - firms established after the } 2008 \text { crisis }(2009-2013) ; 2 \text { - firms founded during the period } \\
\text { of economic growth of } 1999-2008 ; 3 \text { - firms established during the transition crisis of 1992-1998; } 4 \text { - firms } \\
\text { established during the Soviet period (before 1992) }\end{array}$ \\
\hline \multicolumn{2}{|r|}{ Markets indicators } \\
\hline Marketsize & $\begin{array}{l}\text { The categorical variable equals } 1 \text { if a firm is selling its product only in the region where it is located, } 2 \text { if a firm is } \\
\text { operating in other Russian regions as well, and } 3-\text { if a firm is exporting its goods }\end{array}$ \\
\hline Partnerships & $\begin{array}{l}\text { A dummy variable, which equals } 1 \text { if a firm reports having strategic partnerships with Russian partners } \\
\text { established at least } 3 \text { years prior to the interview and } 0 \text { if otherwise }\end{array}$ \\
\hline \multicolumn{2}{|r|}{ Regional indicators } \\
\hline$G R P \_p c$ & Logarithm of Gross Regional Product per capita in 2011 (rubles) \\
\hline Corruption_index & $\begin{array}{l}\text { The aggregated indicator of "every-day corruption" in a firm's home region. The indicator is calculated by the } \\
\text { INDEM Foundation for every Russian region [MED, FOM, 2011]. We use the latest available data (2010). It is } \\
\text { a quantitative indicator varying from } 0 \text { to } 1\end{array}$ \\
\hline \multicolumn{2}{|r|}{ Controls } \\
\hline LogEmpl & Logarithm of the number of employees in 2013 \\
\hline Sector & $\begin{array}{l}\text { Categorical variable for four sectors using the Pavitt taxonomy: } 1 \text { - Supplier-dominated; } 2 \text { - Scale-intensive; } \\
3 \text { - Specialized suppliers; } 4 \text { - Science-based (for further reference see [Pavitt, 1984]). }\end{array}$ \\
\hline
\end{tabular}

We do understand, however, that we may have a problem with reverse causality here. Insufficient profits do constrain growth, but the inadequate scale of business also may be the reason behind low profits. Another proxy for supply-side limitations is the share of old equipment. The coefficients were always negative and strongly significant. This result is more reliable in terms of the reverse causality problem. It demonstrates that firms with relatively outdated equipment may face higher costs of production and/or are incapable of providing goods of a certain quality. The shortage of a qualified workforce, another measure of the supply side deficiencies, also negatively impacts satisfaction with one's scale of business.

As demonstrated in the literature [Smallbone, Welter, 2010], active outsourcing and networking can compensate for the small size of a firm. In other words, a firm can be smaller but just as efficient if it can obtain certain supplies and services from the market. The networking capacities, which we measure by the existence of strategic partnerships, are strongly and positively correlated with the adequacy of firm scale. The existence of established partnerships increases the probability of a firm being happy with its scale of business by more than $14 \%$.

\section{Table 2. Descriptive statistics}

\begin{tabular}{|c|c|c|c|}
\hline Variable & Scale_sufficient & Scale_insufficient & Total \\
\hline Deficit_qual_workers & $18.9 \%$ & $25.1 \%$ & $20.1 \%$ \\
\hline Margin_low & $9.6 \%$ & $17.1 \%$ & $13.3 \%$ \\
\hline External_finance & $38.5 \%$ & $46.7 \%$ & $41.1 \%$ \\
\hline Old_equipment & $23.9(28.8)$ & $31.2(35.4)$ & $27.00(32.0)$ \\
\hline Marketsize1 (regional) & 54.1 & 43.8 & 49.1 \\
\hline Marketsize2 (interregional) & $43.8(36.0)$ & $39.7(37.7)$ & $41.4(36.7)$ \\
\hline Marketsize3 (exporters) & $59.4 \%$ & $68.3 \%$ & $62.5 \%$ \\
\hline Partnerships & $43.6 \%$ & $28.5 \%$ & $36.0 \%$ \\
\hline Corruption_index & $0.51(0.16)$ & $0.52(0.15)$ & $0.52(0.16)$ \\
\hline Age_of_firms1 (after 2008) & 13.04 & 15.53 & 14.15 \\
\hline Age_of_firms2 (1999-2008) & 40.25 & 42.06 & 41.06 \\
\hline Age_of_firms3 (1992-1998) & 29.73 & 25.65 & 27.92 \\
\hline Age_of_firms4 (before 1992) & 16.97 & 16.75 & 16.87 \\
\hline Number of employees & $75.9(63.2)$ & $54.7(52.3)$ & $65.4(58.9)$ \\
\hline GRP_pc (2011, '000 rubles per person) & $255.2(160.3)$ & $242.2(141.1)$ & $251.2(153.1)$ \\
\hline Observations & 716 & 574 & 1290 \\
\hline
\end{tabular}


Table 3. Firm owners' assessment of satisfaction with the current scale of production (marginal effects)

\begin{tabular}{|c|c|c|c|}
\hline \multirow{2}{*}{ Variables } & \multicolumn{3}{|c|}{ Models } \\
\hline & $(1)$ & $(2)$ & (3) \\
\hline Deficit_qual_workers & $-0.0829^{*}(0.0443)$ & $-0.0928^{\star *}(0.0447)$ & $-0.0878^{\star}(0.0458)$ \\
\hline Margin_low & $-0.176^{\star *}(0.0480)$ & $-0.190^{* * *}(0.0490)$ & $-0.196^{* * *}(0.0492)$ \\
\hline External_finance & $-0.0738(0.0459)$ & $-0.0786^{\star}(0.0457)$ & $-0.0792^{\star}(0.0449)$ \\
\hline Old_equipment_share & $-0.002^{\star \star \star}(0.000479)$ & $-0.002^{* * \star}(0.000495)$ & $-0.002^{\star * *}(0.000501)$ \\
\hline Partnerships & $0.142^{\star \star}(0.0636)$ & $0.142^{* \star}(0.0641)$ & $0.142^{\star \star}(0.0657)$ \\
\hline Marketsize2 & $-0.0277(0.0380)$ & $-0.0231(0.0379)$ & $-0.0174(0.0375)$ \\
\hline Marketsize3 & $0.0913(0.0607)$ & $0.105^{\star}(0.0591)$ & $0.111^{*}(0.0585)$ \\
\hline Age2 (1999-2008) & $0.0845(0.0532)$ & $0.0940^{*}(0.0526)$ & $-0.214(0.166)$ \\
\hline Age3 (1992-1998) & $0.122^{\star *}(0.0520)$ & $0.124^{* *}(0.0511)$ & $-0.161(0.171)$ \\
\hline Age4(before 1992) & $0.0303(0.0710)$ & $-0.00194(0.0673)$ & $-0.412^{\star \star \star}(0.138)$ \\
\hline GRP_pc & & $2.63^{* * *}(0.923)$ & $2.67^{\star * *}(0.882)$ \\
\hline Corruption_index & & $-0.162(0.138)$ & $-0.723^{\star * \star}(0.258)$ \\
\hline Age $2^{*}$ Corruption_Index & & & $0.585^{\star}(0.310)$ \\
\hline Age $3{ }^{*}$ Corruption_index & & & $0.540^{*}(0.306)$ \\
\hline Age $4^{\star}$ Corruption_index & & & $0.918^{\star \star}(0.417)$ \\
\hline logNum_Employees & $0.102^{* * *}(0.0219)$ & $0.114^{* * *}(0.0232)$ & $0.114^{* * *}(0.0229)$ \\
\hline Pavitt_gr_2 & $-0.0600(0.0441)$ & $-0.0531(0.0431)$ & $-0.0554(0.0431)$ \\
\hline Pavitt_gr_3 & $-0.0998^{\star *}(0.0477)$ & $-0.123^{\star * *}(0.0441)$ & $-0.119^{* * *}(0.0429)$ \\
\hline Pavitt_gr_4 & $-0.0263(0.0804)$ & $-0.0203(0.0837)$ & $-0.0224(0.0851)$ \\
\hline Pseudo R2 & 0.0683 & 0.0792 & 0.0828 \\
\hline Observations & 1084 & 1057 & 1057 \\
\hline
\end{tabular}

The only "unexpected" result is the negative (though not very significant) impact of the use of bank credits. In other words, firms complaining about their scale of operations use bank loans more often than those who are satisfied with their businesses' performance. Two explanations for this result are probable. On the one hand, it may mean that firms dissatisfied with their scale use external financing extensively in order to increase the size of their businesses. On the other hand, this fact very probably reflects the specific situation in the Russian economy where interest rates, in particular those for SMEs, are relatively high and firms prefer not to take out loans if they can avoid it. Alas, our data does not allow us to confirm which interpretation is more valid. Nevertheless, the first hypothesis can be considered confirmed.

The second hypothesis concerning the inefficient scale of business being linked to demand side limitations was partially confirmed. Though we found no significant differences between firms trading inside their home region and those who trade inter-regionally, exports seem to have a positive impact on the probability of a firm considering their scale sufficient for successfully competing. In addition, the gross regional product per capita, which can be used as a proxy for higher demand, also has a substantial positive coefficient. The hypothesis about demand side factors also explains the significant negative coefficient for the sector of "specialized suppliers" because the market for such products usually is more notably limited, especially in the regions.

The most interesting results relate to the third hypothesis about the impact of the institutional environment on the probability of a firm reaching an optimal scale. As we mentioned earlier, we used a regional index for corruption as a proxy for the quality of the business climate and expected to find (as in other works) the negative impact of corruption on the probability of a firm to having an adequate scale of operations. The calculations in Model 2 confirmed this assumption, its size was statistically insignificant. We expected that the correlation between the level of corruption and the degree of satisfaction with one's scale of operations may depend on the age of the firm in question. Companies operating in an unfavorable institutional environment for a long time (and who have survived) very probably managed to adjust to the environment and have found the ways and means to use the deficiencies of the business climate to their benefit. If the above logic holds true, then younger firms must suffer the most. As our results (Model 3) demonstrate, we found empirical support for this statement. While on the average corruption increases the probability of complaints about scale, the combined effect of age and corruption for the firms established in the pretransition (Soviet) period is positive and statistically significant. In other words, former Soviet enterprises that survived the transition period are much more immune to corrupt environments compared to firms established after 2009. For firms established during the crisis of the 1990s and during the stage of economic growth (1999-2008), the impact of a harmful institutional environment is negative but significantly less so compared to the group of the relatively younger firms. 


\section{Conclusion}

Our research is an attempt to better understand the processes highlighted in the literature on entrepreneurship [Wright, Stigliani, 2012] that underlie entrepreneurial activity and growth in the specific institutional context of Russia.

In the era of the planned economy, large and highly concentrated enterprises dominated the manufacturing sector. One of the great structural shifts during the transition was the downsizing of those large companies and the creation of the SME sector. However, despite the 25 years of transition, the SME segment of Russian economy (in particular, manufacturing SMEs) is still underdeveloped compared to other countries. This can hardly be explained exclusively by the specific industrial structure of the economy or by pathdependence. Nevertheless, the fact remains that among the seven EU countries, the only transitioning economy, Hungary, had the highest ratio of SME managers dissatisfied with the scale of operations, which indicates that the transition may be partly responsible. However, the stagnation in the development of SMEs in Russia demonstrates that the problems cannot be explained by an unfinished transition alone.

In a comparison of the statistics collected during the large-scale business survey for the seven EU countries and for Russia, we show that there are a distinct differences in the share of SMEs in the manufacturing sector that consider their scale of operations sufficient for competing on the market. Approximately half of the manufacturing SMEs in Russia would like to increase their operations compared with less than $15 \%$ in EU countries. However, in terms of employment, Russian SMEs are comparable to their European counterparts though they lag behind in terms of turnover. In this paper, we have attempted to investigate the reasons why Russian SMEs are so dissatisfied with the scale of their operations. Or, more precisely, what is the difference between the firms complaining about their scale of activity and those who manage to reach an adequate scale of production? We presumed that a firm's inability to grow to an optimal scale may be due to the three groups of factors. These include those on the supply side, a lack of access to the resources necessary for growth, those on the demand side, the small size of the market and an inability to overcome this limitation by entering broader markets (due to the high transaction costs), and, finally, the unfavorable business environment that prevents the growth of small and medium businesses.

Our findings partially correspond to the previous empirical literature on developing and transitional economies. Our overall results indicate that "good" firms in terms of performance and resources (such as access to qualified labor, new equipment, business networks, etc.) have more chances to reach an adequate scale. We found also that the size of the market upon which firms are selling their products also matters: access to export markets increases the probability of a firm being satisfied with their scale of business by $10 \%$. In addition, a location in more prosperous regions (regions with a higher gross regional product per capita) also has a positive impact on a manager's satisfaction with the scale of production.

Some new, interesting results of the paper are related to the impact of the institutional environment on firms' satisfaction with their production scale. Using the regional corruption index as a proxy for the quality of the institutional environment, we found that a corrupt environment has a negative impact on the perception of adequate scale. However, this effect depends upon the generation to which firms belong. It is extremely negative for the relatively young firms that are less than five years old, especially compared to the old former Soviet enterprises. Our findings demonstrate that SMEs that have managed to survive in an unfavorable environment for some time eventually adjusted to some extent to the existing business climate. It might be posited that only those firms that manage to learn how to bargain with inefficient institutions have a chance of survival (and help this system become self-sustaining). This may be one of the reasons why there are so few SMEs in the Russian manufacturing sector compared to other countries and the reason why so few of them are able to successfully compete on foreign markets. The unfavorable environment may be one of the reasons why Russian firms are so dissatisfied with their current scale: high bureaucratic barriers and transaction costs make smaller firms more vulnerable to administrative pressure. Therefore, a firm in Russia must be larger than its counterpart in a developed economy to survive and remain on the market.

The study was implemented in the framework of the Basic Research Program at the National Research University Higher School of Economics (HSE) in 2015-2017.

\section{References}

Acs Z., Audretch D. (2001) The Emergency of the Entrepreneurial Society. Paper presented at the International Award for Entrepreneurship and Small Business research, 3 May, 2001, Stockholm.

Acs Z., Armington C. (2004) Employment growth and entrepreneurial activity in cities. Regional Studies, vol. 38, no 8, pp. 911-927.

Aidis R. (2015) Is Russia an entrepreneurial society? Challenges for Russia’s Politicized Economic System (ed. Susanne Oxentierna), New York: Routledge, pp. 77-95.

Aidis R., Estrin S., Mickiewicz T. (2008) Institutions and entrepreneurship development in Russia: A comparative perspective. Journal of Business Venturing, vol. 23, no 6, pp. 656-672.

Aghion P., Howitt P. (1997) Endogenous Growth Theory, Cambridge, MA: MIT Press.

Autio E., George G., Alexy A. (2011) International Entrepreneurship and Capability Development - Qualitative Evidence and Future Research Directions. Entrepreneurship: Theory and Practice, vol. 35, no 1, pp. 11-37. 
Ahrend R. (2006) Russian industrial restructuring: Trends in productivity, competitiveness and comparative advantage. Post-Communist Economies, vol. 18, no 3, pp. 277-295.

Bartelsman E., Haltiwanger J., Scarpetta S. (2013) Cross-country differences in productivity: The role of allocation and selection. The American Economic Review, vol. 103, pp. 305-334.

Bennet V., Levinthal D. (2017) Firm lifecycles: Linking employee incentives and firm growth dynamics. Strategic Management Journal. DOI 10.1002/smj.2644.

Bhaumik S.K., Estrin S. (2007) How transition paths differ: Enterprise performance in Russia and China. Journal of Development Economics, vol. 82, no 2, pp. 374-392.

Blagojevic S., Damijan J.P. (2013) The imact of corruption and ownership on the performance of firms in Central and Eastern Europe. Post-Communist Economies, vol. 25, no 2, pp. 133-158.

Bruno R.L., Bytchkova M., Estrin S. (2008) Institutional determinants of new firm entry in Russia: A cross regional analysis (Quaderni - Working Paper DSE no 650). Available at: https://www.econstor.eu/bitstream/10419/159491/1/ wp0650.pdf, accessed 24.06.2017.

Chepurenko A. (2012) Chto takoe predprinimatel'stvo I kakaya politika v otnoshenii predprinimatel'stva nuzhna $\mathrm{v}$ Rossii (Zametki na polyakh rabot zarubezhnykh klassikov) [What is entrepreneurship and what political approach to entrepreneurship does Russia need? (Marginal Notes on Works of Modern Foreign Classics)]. Zhurnal Novoi Ekonomicheskoi Assotsiatsii [Journal of the New Economic Association], vol. 14, no 2, pp. 102-124 (in Russian).

Chepurenko A. (2015) Entrepreneurial activity under "transition". Context, Process and Gender Entrepreneurship: Frontiers in European Entrepreneurship Research (eds. R. Blackburn, U. Hytti, F. Welter), Cheltenham: Edward Elgar, pp. 6-22.

Cuaresma J.C., Oberhofer H., Andronova Vincelette G. (2013) Firm growth and productivity in Belarus: New empirical evidence from the machine building industry. Journal of Comparative Economics, vol. 42, no 3, pp. 726738.

Dallago B. (2000) The Organizational and Productive Impact of the Economic System: The Case of SMEs. Small Business Economics, vol. 15, no 4, pp. 303-319.

Djankov S. (1999) The restructuring of insider-dominated firms: A comparative analysis. Economics of Transition, vol. 7, no 20, pp. 467-479.

EBRD (2013) The Business Environment and Enterprise Performance Survey. The Russian Regions: Results, London: European Bank for Reconstruction and Development. Available at: http://www.ebrd.com/downloads/research/ factsheets/beeps.pdf, accessed 17.04.2017.

Ericson R., Pakes A. (1995) Markov-perfect industry dynamics: A framework for empirical research. Review of Economic Studies, vol. 62, no 1, pp. 53-82.

Estrin S., Bevan A., Kuznetsov B., Schaffer M., Angelucci M., Fennema J., Mangiarotti G. (2001) The Determinants of Privatised Enterprise Performance in Russia (William Davidson Institute Working Papers Series 452), Ann Arbor, MI: University of Michigan.

Estrin S., Meyer K., Bytchkova M. (2006) Entrepreneuship in transition economies. The Oxford Handbook of Entrepreneurship (eds. M. Casson, B. Yeung, A. Basu, N. Wadeson), Oxford: Oxford University Press, pp. 693-725.

Estrin S., Korosteleva J., Mickiewicz T. (2013) Which institutions encourage entrepreneurial growth aspirations? Journal of Business Venturing, vol. 28, pp. 564-580.

Filatotchev I., Buck T., Zhukov V. (2000) Downsizing in privatized firms in Russia, Ukraine, and Belarus. Academy of Management Journal, vol. 43, no 3, pp. 286-304.

Foster L., Haltiwanger J., Syverson C. (2012) The slow growth of new plants: Learning about demand? (NBER Working Paper 17853), Cambridge, MA: National Bureau of Economic Research.

Golikova V., Ermilova G. (2006) Competitiveness of Small Enterprises: Evidence from Empirical Survey in Two Russian Regions. Institute of Economic Research Discussion Paper Series B, no 34: New Generation of Russian Economic Studies, Tokyo: Hitotsubashi University, pp. 39-64.

González A., Leonardo I., Hari S. (2013) Russian volatility: Obstacle to firm survival and diversification (Policy Research Working Paper WPS 605), Washington, DC: World Bank.

Geurts K., van Biesebroek J. (2016) Firm creation and post-entry dynamics of de novo entrants. International Journal of Industrial Organization, vol. 49(C), pp. 59-104.

Hermans J., Vanderstraeten J., Dejardin M., Ramdani D., Stam E., van Witteloostuijn A. (2012) Ambitious entrepreneurship: Antecedents and consequences (Research Paper 2012-023), Antwerpen: University of Antwerpen.

Hessels J., Parker S.C (2013) Constraints, Internationalization and Growth: A Cross-Country Analysis of European SMEs. Journal of World Business, vol. 48, no 1, pp. 137-148.

Hsieh C.T., Klenow P. (2009) Misallocation and Manufacturing TFP in China and India. The Quarterly Journal of Economics, vol. 124, no 4, pp. 1403-1448.

Hoskisson R.E., Eden L., Lau C.M., Wright M. (2000) Strategy in emerging economies. Academy of Management Journal, vol. 43, no 3, pp. 249-267.

Hoskisson R., Covin J., Volberda H., Johnson R. (2011) Revitalizing entrepreneurship: The search for new research opportunities. Journal of Management Studies, vol. 48, no 6, pp. 1141-1168.

MED, FOM (2011) Sostoyanie bytovoi korruptsii v Rossiiskoi Federatsii [State of the everyday corruption in the Russian Federation], Moscow: Ministerstvo ekonomicheskogo razvitiya Rossiiskoi Federatsii [Ministry of Economic Development of the Russian Federation], Fond "Obshchestvennoye Mneniye" [Public Opinion Foundation]. Available at: http://www.indem.ru/corrupt/doklad_cor_INDEM_FOM_2010.pdf (in Russian).

Iwasaki I., Maurel M., Meunier B. (2016) Firm entry and exit during a crisis period: Evidence from Russian regions. Russian Journal of Economics, vol. 2, no 2, pp. 162-191.

Jovanovic B. (1982) Selection and Evolution of Industry. Econometrica, vol. 50, no 3, pp. 25-43.

Kolvereid L. (1992) Growth aspirations among Norwegian entrepreneurs. Journal of Business Venturing, vol. 7, no 3, pp. 209-222.

Krasniki B., Desai S. (2016) Institutional drivers of high-growth firms: Country-level evidence from 26 transition economies. Small Business Economics, vol. 47, no 4, pp. 1075-1094.

Lee N. (2014) What holds back high-growth firms? Evidence from UK SMEs. Small Business Economics, vol. 43, no 1, pp. 183-195.

Linz S.J., Krueger G. (1998) Enterprise restructuring in Russia's transition economy: Formal and informal mechanisms. Comparative Economic Studies, vol. 40, no 2, pp. 5-52.

Manev I., Manolova T. (2010) Entrepreneurship in transition economies: Review and intergration of two decades of research. Journal of Developmental Entrepreneurship, vol. 15, no 1, pp. 69-99.

Marcelin I., Mathur I. (2015) Privatization, Financial Development, Property Rights and Growth. Journal of Banking and Finance, vol. 50 (C), pp. 528-546. 
Mason C., Brown R. (2013) Creating good public policy to support high-growth firms. Small Business Economics, vol. 40, no 2, pp. 211-225.

Melitz M.J. (2003) The Impact of Trade on Intra-Industry Reallocations and Aggregate Industry Productivity. Econometrica, vol. 71, no 6, pp. 1695-1725.

Meyer K., Peng M. (2005) Probing theoretically into Central and Eastern Europe: Transactions, resources, and institutions. Journal of International Business Studies, vol. 36, no 6, pp. 600-621.

Meyer K., Peng M. (2016) Theoretical foundations of emerging economy business research. Journal of International Business Studies, vol. 47, no 1, pp. 3-22.

Mohr V., Garnsey E., Theyely G. (2014) The role of alliences in the early development of high-growth firms. Industrial and Corporate Change, vol. 23, no 1, pp. 233-259.

Molz R., Tabbaa I., Totskaya N. (2009) Institutional Realities and Constraints on Change: The Case of SME in Russia. Journal of East-West Business, vol. 15, no 2, pp. 141-156.

Navaretti G.B., Castellani D., Pieri F. (2014) Age and firm growth: Evidence from three European countries. Small Business Economics, vol. 43, no 4, pp. 823-837.

Navaretti G.B., Altomonte C., Bugamelli M., Schivardi F., Horgos D., Maggioni D. (2010) The Global Operations of European Firms (Second EFIGE Policy Report, BREUGEL, Nov' 10), Brussels: BRUEGEL. Available at: http:// bruegel.org/wp-content/uploads/imported/publications/efige_II_ws_14711.pdf, accessed 12.04.2017.

OECD (2015) Russian Federation: Key Issues and Policies. OECD Studies on SMEs and Entrepreneurship, Paris: OECD.

OPORA (2016) Antikrizisnyi monitoring OPORY ROSSII [OPORA's Anti-crisis monitoring], Moscow: OPORA. Available at: http://www.opora.ru/upload/iblock/f53/f53f9e8a614f68632850d774edef8b6f.pdf (in Russian).

Ojala A., Isomaki H. (2011) Entrepreneurship and small business in Russia: A review of empirical research. Journal of Small Business and Enterprise Development, vol. 18, no 1, pp. 97-119.

Pakes A., Ericson R. (1998) Empirical implications of alternative models of firm dynamics. Journal of Economic Theory, vol. 70, no 1, pp. 1-45.

Pavitt K. (1984) Sectoral patterns of technical change: Towards a taxonomy and a theory. Research Policy, vol. 13, pp. 343-373.

Peng M.W. (2001) How entrepreneurs create value in transition economies. Academy of Management Executive, vol. 15, no 1, pp. 95-108.

Ployhart R., Moliterno T. (2011) Emergence of human capital resource: Multilevel approach. Academy of Management Review, vol. 36, no 1, pp. 127-150.

Puffer S.M., McCarthy D.J., Boisot M. (2010) Entrepreneuship in Russia and China: The impact of formal institutional voids. Entrepreneurship Theory and Practice, vol. 34, no 3, pp. 441-467.

Rajan R., Zingales L. (1998) Financial Dependence and Growth. American Economic Review, vol. 88, no 3, pp. 559586.

Rice J., Liao T.-S., Martin N., Galvin P. (2012) The role of strategic alliances in complementing firm capabilities. Journal of Management and Organization, vol. 18, no 6, pp. 859-869.

Richter A., Schaffer M.E. (1996) The Performance of De Novo Private Firms in Russian Manufacturing (CERT Discussion Paper no 9610), Edinburgh: Center for Economic Reform and Transformation.

Rosstat (2014) Maloe i srednee predprinimatel'stvo v Rossii [Small and medium entrepreneurship in Russia], Moscow: Rosstat. Available at: http://www.gks.ru/free_doc/doc_2014/mal-pred-all.rar, accessed 17.03.2016 (in Russian).

Sharafutdinova G., Kisunko G. (2014) Governors and Governing Institutions: A Comparative Study of State-Business Relations in Russia's Regions (Policy Research Working Paper WPS 7038) Washington, D.C.: World Bank, Governance Global Practice Group.

Smallbone D., Welter F. (2010) Enterpreneurship and the Role of Government in Post-Socialist Economies: Some Institutional Challenges. Historical Social Research, vol. 35, no 2, pp. 320-333.

Smallbone D., Welter F., Ateljevic J. (2014) Entrepreneurship in emerging market economies: Contemporary issues and perspectives. International Small Business Journal, vol. 32, no 2, pp. 113-116.

Song Z., Storesletten K., Zilibotti F. (2011) Growing like China. The American Economic Review, vol. 101, no 1, pp. 196-233.

Stenholm P., Toivonen J. (2009) The attributes of firm growth - Why and why not a firm does grow. Frontiers of Entrepreneurship Research, vol. 29, no 13, article 4. Available at: http://digitalknowledge.babson.edu/cgi/ viewcontent.cgi? article $=1590 \&$ context $=$ fer, accessed 25.04.2016.

Street C.T., Cameron A.-F. (2007) External Relationships and the Small Business: A Review of Small Business Alliance and Network Research. Journal of Small Business Management, vol. 45, no 2, pp. 239-266.

Thorsten B., Demirgüç-Kunt A. S. L. I., Maksimovic V. (2005) Financial and legal constraints to growth: Does firm size matter? The Journal of Finance, vol. 60, no 1, pp. 137-177.

Tybout J. (2000) Manufacturing Firms in Developing Countries: How Well Do They Do, and Why? Journal of Economic Literature, vol. 38, no 1, pp. 11-44.

Volchek D., Henttonen K., Edelmann J. (2013a) Exploring the Role of a Country's Institutional Environment in Internationalization: Strategic Responses of SMEs in Russia. Journal of East-West Business, vol. 19, no 4, pp. $317-$ 350.

Volchek D., Jantunen A., Saarenketo S. (2013b) The institutional environment for international entrepreneurship in Russia: Reflections on growth decisions and performance in SMEs. Journal of International Entrepreneurship, vol. 11, no 4, pp. 320-350.

Wang Yu., You J. (2012) Corruption and firm growth: Evidence from China. China Economic Review, vol. 23, no 2, pp. $415-433$.

Weber P., Geneste L.A., Connell J. (2015) Small business growth: Strategic goals and owners' preparedness. Journal of Business Strategy, vol. 36, no 3, pp. 30-36.

Welter F., Smallbone D. (2011) Institutional Perspectives on Entrepreneurial Behavior in Challenging Environments. Journal of Small Business Management, vol. 49, no 1, pp. 107-125.

Wright M., Stigliani I. (2012) Entrepreneurship and growth. International Small Business Journal, vol. 31, no 1, pp. 3-22.

Yakovlev E., Zhuravskaya E. (2007) Deregulation of Business (CEPR Discussion Paper no 6610), London: Centre for Economic Policy Research.

Yukhanaev A., Fallon G., Baranchenko Y., Anisimova A. (2015) An Investigation into the formal institutional constraints that restrict entrepreneurship and SME growth in Russia. Journal of East-West Business, vol. 21, no 4, pp. 313-341. 


\title{
Innovation Configurations in Knowledge- Intensive Business Services
}

\author{
Ian Miles ${ }^{\text {a;b }}$ \\ Professor, Manchester Business School; Head of Laboratory for Economics of Innovation, Institute for Statistical \\ Studies and Economics of Knowledge (ISSEK), ian.miles@mbs.ac.uk
}

\section{Veronika Belousova ${ }^{b}$}

Associate Professor, Head of Department of Educational Programmes, and Head of Department for Methodology of Budget Planning, ISSEK, vbelousova@hse.ru

\section{Nikolay Chichkanov ${ }^{\mathrm{b}}$}

Research Assistant, Department for Methodology of Budget Planning, ISSEK, nchichkanov@hse.ru

${ }^{\text {a }}$ University of Manchester, Oxford Rd, Manchester M13 9PL, UK.

${ }^{\mathrm{b}}$ National Research University Higher School of Economics, 20 Myasnitskaya str., Moscow 101000, Russian Federation.

\begin{abstract}
$\mathrm{K}$

nowledge-intensive business services (KIBS) industries demonstrate some of the highest levels of innovation in most developed economies. However, these industries are very heterogeneous. Research on their innovative activities is needed in order to provide evidence to inform policy instruments to support such companies.

In this paper, we analyze the innovation configurations of 477 Russian KIBS companies. First, we use factor analysis to study the key features of their innovative

behavior: different innovation types and different features of demand for KIBS from innovative clients (volume, range and level of customization of services). Three factors emerge and the KIBS companies are divided into six clusters through the prism of these factors. The clusters are: non-innovators; organizational change innovators; marketing innovators; technology-oriented innovators; non-technological innovators and diversified innovators. Finally, we examine the distribution of companies across the clusters in terms of their size and the type of services.
\end{abstract}

Keywords: innovation types; service innovation; knowledge-intensive business services; professional services; SMEs.

Citation: Miles I., Belousova V., Chichkanov N. (2017) Innovation Configurations in Knowledge-Intensive Business Services? Foresight and STI Governance, vol. 11, no 3, pp. 94-102. DOI: 10.17323/2500-2597.2017.3.94.102 
$\mathrm{T}$ The service sector plays a key role in the modern economy. According to the Organisation for Economic Cooperation and Development (OECD) experts, services make a major contribution to employment growth and increased public well-being in many of the organization's member countries [OECD, 2017]. Within the service industry, knowledge-intensive business services (KIBS) demonstrate particularly high growth rates, including in developing countries [Janger et al., 2017]. In China, the added value created in KIBS industries grew more than fivefold between 2004 and 2014 [Fang et al., 2016].

KIBS rank among the most innovative sectors in the European Union's Community Innovation Survey (CIS). Gotsch et al. (2011) demonstrated, using data from CIS-2004, that European KIBS firms were more likely to be engaged in innovation than their manufacturing counterparts.

In Russia, KIBS companies also have a high share of added value in their revenues, despite the appreciable slowdown of the sector's growth after the 2008 crisis - when the average level of added value dropped from $46 \%$ in 2007 to 38\% in 2013 [Berezin, Doroshenko, 2015]. Comparing the dynamics of Russian KIBS with their European counterparts reveals that the shares of leading Russian KIBS companies engaged in technological and marketing innovations (39.6\% and $23.8 \%$, respectively) are comparable with typical firms in the UK (39.6\% and 20.8\%) or Denmark (38.7\% and 27.6\%) $)^{1}$. Meanwhile regarding organizational innovations, these Russian KIBS significantly lag behind those in European nations (the share of companies who use such innovations in Russia is $25.5 \%$, compared with $40.8 \%$ in the UK, $41.2 \%$ in Germany, and $48.6 \%$ in Switzerland).

Some ambiguity remains regarding the sector's scope, in large part because KIBS do not coincide neatly with the sectoral classifications of established statistical systems. ${ }^{2}$ The first attempt at a definition, by Miles et al. [Miles et al., 1995], identified the three main characteristics of the relevant enterprises: the active application of professional knowledge; the provision of services, which may serve as knowledge sources alone, or are based on knowledge customers need for their business operations; and a focus primarily on corporate clients (but also supporting business processes at public sector organizations). However, industries displaying the above characteristics still remain highly varied [Freel, 2010; Gotsch et al. 2011], not least in terms of innovative behavior. The main objective of this paper is to examine the innovation configurations of KIBS firms, while also contributing to empirical studies on this sector in Russia. We can see that innovation type could be influenced by both supply-side (knowledge base) and demand-side (customer requests) factors. However, though demand is often featured as a driver, there is a lack of evidence on its impact on innovation activities in KIBS. In this study, we are able to investigate both sets of issues. We shall examine the relationship between innovation type and market demand, and then relate this to the type of involved service/knowledge base.

The paper begins with a review of earlier empirical studies of KIBS companies and their innovation activities; we then present our sources of information and the methodology used to analyze the innovation configurations of Russian KIBS firms; finally, we then present the results of the analysis, and formulate conclusions.

\section{Literature review \\ Features of KIBS firms and industries}

Two kinds of knowledge-intensive business services are usually defined: the professional services (KIBS I, P-KIBS) and new technological services (KIBS II, T-KIBS) [Miles et al., 1995]. The first type of KIBS comprises companies providing accounting, legal, management consultancy, and similar professional services. A specific feature of such industries, many of which have a long history, is the active application of specialized knowledge in the administrative and organizational domains [Miles, 2012] to help their clients deal with problems encountered in these areas [Miles et al., 1995]. T-KIBS have mostly emerged more recently, prompted by the emergence of new technologies and related global challenges [Miles et al., 1995]. Industries belonging in this segment include the design and maintenance of computer systems, software design, and engineering services. The newly created knowledge is closely related to new technologies, and KIBS play a role in creating and transferring such technologies to their clients [Amara et al., 2008; Landry et al., 2012]. Some more recent studies have suggested a third category: C-KIBS [Miles, 2012] or CIBS [Masiello et al., 2014] - to highlight creativity-based KIBS, where the critical forms of knowledge are those of a cultural or symbolic nature: advertising and design are examples of this group. Not surprisingly, these different types of knowledge mean that companies belonging to different segments of the sector vary in some key respects. In terms of innovation, it is argued that the level of interaction with customers and suppliers is critically important to innovative P-KIBS companies [Freel,

\footnotetext{
${ }^{1}$ The most recent available CIS data (for 2014) for European countries (available at http://ec.europa.eu/eurostat/web/sciencetechnology-innovation/data/database), and data collected in the scope of the HSE ISSEK study "Monitoring of KnowledgeIntensive Business Services in Russia" in 2015 was used for comparison.

${ }^{2}$ In the first version of the standard NACE classification, KIBS could be roughly associated with Industry divisions 72,73 and much of 74 (but other, more operational services were also located here); in the revised second version of NACE, most KIBS fall into section M, but Information and Communication Technology KIBS are located in section J with many other information and communication activities [Schnabl, Zenker, 2013].
} 
2006]. T-KIBS, on the other hand, depend more on their own internal innovation resources. They engage in unusually high levels of R\&D for service firms, but Pinto et al. [Pinto et al., 2015] argue that it is the qualifications of their staff that forms the most important contribution. The process of new companies' (start-ups) emergence is also quite segment-specific, with new T-KIBS firms appearing to be much more dependent upon the existing structure of regional economies [Wyrwich, 2013].

\section{Factors affecting KIBS companies' innovative behavior}

Innovation activities in KIBS are usually viewed through the prism of modes of innovation, which involves identifying distinctive patterns of innovative behavior. Three major groups of factors are commonly studied: innovation types; sources of knowledge and information; and companies' expenditures on innovation. The types of innovation are most commonly used to distinguish between KIBS. The standard guide for innovation statistics, the Oslo Manual, distinguishes between product, process, marketing, and organizational innovations [OECD, Eurostat, 2005]. Product innovation involves "the introduction of a good or service that is new or significantly improved with respect to its characteristics or intended uses" [Ibid., p. 48]. Process innovation is "the implementation of a new or significantly improved production or delivery method" for products or services [Ibid., p. 49]. Product and process innovations are often put together into one group of technological innovations; combining them in this way may makes sense for KIBS (and many other services) where the border between a service and the process of its delivery and provision is often unclear [Santos-Vijande et al., 2012]. However, neither product nor process innovation necessarily has to involve new technology. For instance, a KIBS firm specializing in a service like law or engineering may introduce a completely new service - many KIBS firms have developed consultancy offerings - without the use of any new technologies).

The other two innovation types are not linked with production as such. A marketing innovation is defined as "the implementation of a new marketing method involving significant changes in product design or packaging, product placement, product promotion or pricing" [OECD, Eurostat, 2005, p. 49]. For example, this might involve the promotion of a new brand. Finally, organizational innovations involve "the implementation of a new organisational method in the firm's business practices, workplace organization or external relations" [Ibid., p. 51].

Other innovation types not specified in the Oslo Manual are also frequently considered in KIBS studies. They include, for example, new techniques for conducting client relations [Amara et al., 2009; Doloreux, Shearmur, 2010]. The business environment frequently generates such innovation types by itself. For example, Deloitte suggested extending the range of client relations innovations by including service provision and promotion techniques, and by involving customers in co-production. Such innovations are common in the social media [Keeley et al., 2013].

New ways of relating to and cooperating with other external partners, not with customers alone, are also very important to KIBS companies since they involve integrating specific professional knowledge to create new solutions [Amara et al., 2009]. Researchers suggest that the sources of knowledge and information KIBS companies use to create and apply innovations are another important group of factors contributing to the mode of innovation. Customers, suppliers, and competitors are major sources [Corrocher et al., 2009; Rodriguez et al., 2015], while partners such as franchises or professional associations are another [Rodriguez, Camacho, 2010]. A third way of acquiring specialized knowledge and information is to purchase it, in particular, from consulting firms [Asikainen, 2015]. Finally, KIBS firms may cooperate with the "science base" of universities and research centers, and of course they gather information by participating in relevant conferences and perusing research publications [Doloreux and Shearmur, 2010; Asikainen, 2015].

A third group of factors used in considering KIBS companies' modes of innovation comprises relevant expenditures. Innovation studies have tended to focus on R\&D expenditures, but R\&D is much less prevalent in the service industries than in manufacturing. T-KIBS are an exception here, and some firms are very R\&D-intensive. Traditionally these first of all include internal and external R\&D infvestments [Rodriguez, Camacho, 2010; Rodriguez et al., 2015]. However, KIBS companies frequently lack specialized R\&D departments and place much emphasis on the role of human capital [Schricke et al., 2012]. Therefore in-house and external staff training and other personnel development activities become important areas for expenditures [Corrocher et al., 2009; Asikainen, 2015; Rodriguez et al., 2015].

As in other industries, another major spending area, often the largest, can also be understood as expenditures on external sources of knowledge and information. This includes the acquisition of specialized equipment, software and other information and communication technologies as well as data procured from consulting companies [Doloreux, Shearmur, 2010; Rodriguez, Camacho, 2010]. Finally, the protection of intellectual property is an important innovation-related investment area [Asikainen, 2015]. Patents are not particularly relevant for most in the KIBS sector, though there are exceptions for some T-KIBS. However, copyright, trademarks, and other mechanisms can be used. In common with many industries, less formal methods of protection, such as secrecy and employee confidentiality are often used [Miozzo et al., 2016; Schricke et al., 2012]. 
Table 1. Descriptive statistics

\begin{tabular}{|c|c|c|c|}
\hline Indicator & $\mathbf{N}$ & $\begin{array}{c}\text { Average } \\
(0=\text { no innovation, } \\
1=\text { innovation })\end{array}$ & $\begin{array}{l}\text { Standard } \\
\text { deviation }\end{array}$ \\
\hline Application of technological innovations & 477 & 0.42 & 0.49 \\
\hline Application of marketing innovations & 477 & 0.29 & 0.45 \\
\hline Application of organizational innovations & 477 & 0.37 & 0.48 \\
\hline Application of communication innovations & 477 & 0.40 & 0.49 \\
\hline When customers' own innovation activities increase, they step up orders & 477 & 0.36 & 0.48 \\
\hline $\begin{array}{l}\text { When customers' own innovation activities increase, they extend the } \\
\text { range of services they order }\end{array}$ & 477 & 0.32 & 0.47 \\
\hline $\begin{array}{l}\text { When customers' own innovation activities increase, they order more } \\
\text { customized services }\end{array}$ & 477 & 0.18 & 0.39 \\
\hline
\end{tabular}

\section{Data and methodology}

The data used in this study of Russian KIBS derives from a survey ("Monitoring of Knowledge-Intensive Business Services in Russia" study conducted by the HSE ISSEK in 2013). A two-stage quota sampling method was used. Quotas for company location ${ }^{3}$ were first established and followed by quotas set for company size and industry. The data thus date from before the external political and, subsequently, the economic crisis that began in 2014. The sample consists of firms in ten KIBS industries (advertising, marketing, audit, information technology, HR consulting, engineering, financial brokerage, legal services, property development services, and design). Companies unable to answer questions regarding specific features of their innovative behavior were excluded from the original sample of $623 \mathrm{firms}$, leaving 477 companies in the final sample.

In terms of company size ${ }^{4}$, small and medium companies with fewer than 250 employees made up the bulk of the sample: $29 \%$ were micro-enterprises with 15 employees or fewer, while $42 \%$ employed between 16 and 49 people. In terms of revenue, ${ }^{5} 56.6 \%$ of companies generated less than 150 million rubles of sales turnover, which puts them in the Russian definition of small and medium sized enterprises ${ }^{6}$. When asked about their size relative to other firms in their sector, $46 \%$ of the surveyed companies positioned themselves as medium-sized and $36 \%$ as small.

KIBS companies' innovation configurations were analyzed using a two-stage procedure similar to that employed in earlier studies [Camacho, Rodriguez, 2008; Corrocher et al., 2009; Rodriguez, Camacho, 2010]. In the first stage, factor analysis was employed (using the principle components analysis technique with a varimax rotation); this effectively reduced the number of indicators that we examined to a smaller set of distinctive compound variables (factors). In the second stage, scores on these factors were used in a cluster analysis (based on the k-means technique), which locates companies belonging to specific clusters. The clusters are differentiated in terms of the involved factor scores.

The variables considered in this analysis reflect those discussed in the literature review, taking into account what questions actually were asked in the survey. Specifically, we studied the incidence of various innovation types across companies. Along with the types described in the Oslo Manual (technological, marketing, and organizational innovations), we also took into account communication innovations, i.e., the mechanisms companies use to interact with their customers and others. Respondents were asked about the introduction of innovations in the current year. Questions about CIS, in contrast, concern the preceding three years.

Customers are often a key source of corporate knowledge and information for KIBS firms, and cooperating with them in designing and producing services may lead to innovations [den Hertog, 2000]. Three variables concern the relationship between the clients' innovative activities and their demand for KIBS (not only in terms of the amount of services required, but also their range and degree of customization). Descriptive statistics for these variables are shown in Table 1.

\footnotetext{
3 The survey was carried out in large cities from those Federal Districts which contributed more than 10\% to GDP in 2012. The five federal districts and cities were: Central (Moscow, Voronezh), North-West (St. Petersburg), Volga (Kazan, Nizhny Novgorod, Samara), Siberia (Krasnoyarsk, Novosibirsk, Omsk, Tomsk) and Ural (Yekaterinburg, Chelyabinsk).

${ }^{4}$ In line with the criteria specified in the Federal Law № 209-FZ “On development of small and medium entrepreneurship in the Russian Federation" (as amended on 03.07.2016).

${ }^{5}$ In line with the Regulation No. 101 "On maximum revenue from each small and medium enterprises group" of 09.02.2013. However, now income from entrepreneurial activities are used to classify SMEs rather than revenue (Regulation No. 265 of 04.04.2016).

${ }^{6} 37.7 \%$ of companies did not provide data on their revenue.
} 
Table 2. Factor analysis results

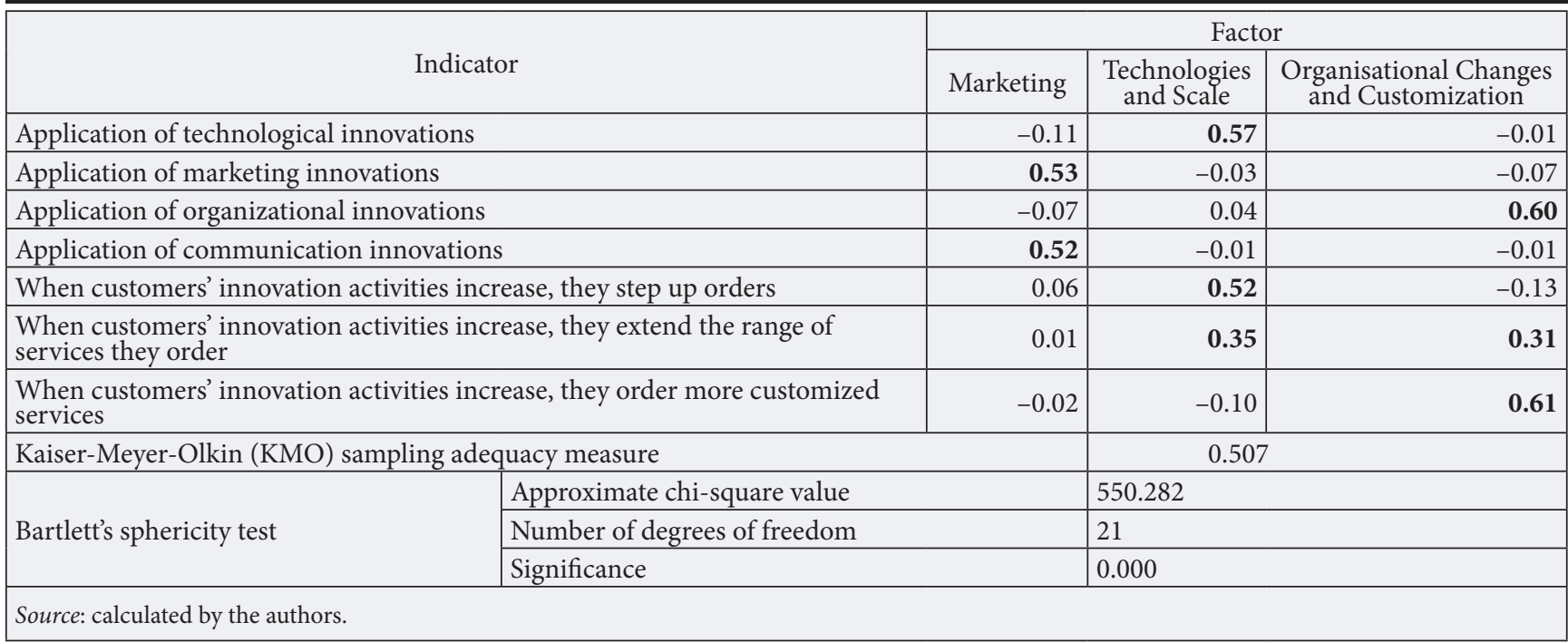

As all variables in Table 1 are binary, the averages can be interpreted as the percentage of firms reporting this sort of innovation, or giving an affirmative answer to the questions. We see from these results that each of the types of innovation was reported as undertaken by a minority of the KIBS, though this was always substantial (ranging from $29 \%$ for marketing innovations to about $40 \%$ for the other types). Innovation on the part of customers is seen as driving demand for KIBS to a lesser extent: the least significant effect was reported in terms of increasing demand for customized services. Only around a third of the firms reported increases in the range or volume of services required.

Figure 1 presents data on the shares of KIBS firms undertaking two, three, or four of the discussed types of innovation. It is clear that many companies focus only on one type of innovation, with two innovations reported only marginally more so than no innovations at all (about $20 \%$ of the companies).

We can contrast firms of different types (in terms of their size and the services they provide), in terms of innovation types, but we must first explore how these variables relate to one another. By so doing we will reduce the number of variables, and thus make the analysis more concise.

\section{Factor and Cluster Results}

Factor analysis results are presented in Table $2^{7}$. Three factors with eigenvalues greater than 1 account for more than $62.5 \%$ of the variance ${ }^{8}$.

The most striking feature of these results is that different types of innovation emerge as distinctive and independent dimensions, with one exception: communication and marketing innovations are closely related. The implication is, with this exception, that there is little tendency for one or another innovation to accompany each other in this sample of KIBS firms, despite the assertion that is often made in the

\section{Figure 1. Numbers of types of innovations implemented by KIBS (\%)}

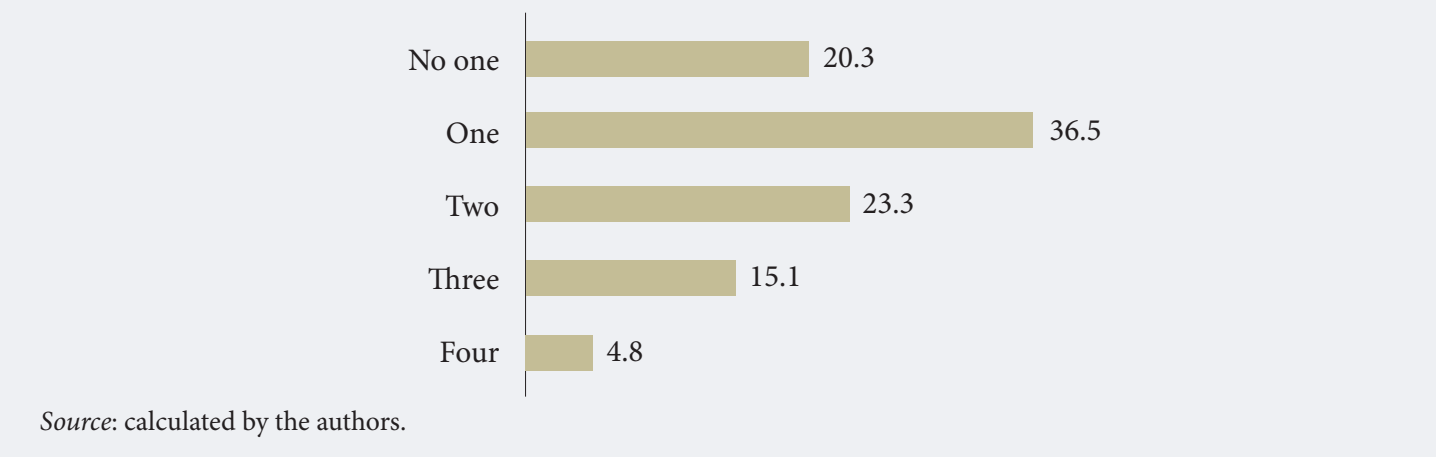

\footnotetext{
Factor analysis is, strictly, not applicable to non-parametric data, and our variables are binary. However, many researchers find the application of these methods useful for pointing out meaningful patterns in the data, as appears to be the case in the present study.

${ }^{8}$ We validate the sample adequacy with the Kaiser-Meyer-Olkin test and the strength of correlation between variables using Bartlett's test of sphericity. Both tests indicate that the factor analysis could be applied to the data with an accepted level of relevance.
} 
Table 3. Cluster analysis results

\begin{tabular}{|c|c|c|c|c|}
\hline \multirow[b]{2}{*}{ Cluster } & \multicolumn{3}{|c|}{ Factor } & \multirow{2}{*}{$\begin{array}{l}\text { Number of } \\
\text { companies }\end{array}$} \\
\hline & Marketing & $\begin{array}{l}\text { Technologies } \\
\text { and Scale }\end{array}$ & $\begin{array}{l}\text { Organizational Changes } \\
\text { and Customization }\end{array}$ & \\
\hline Non-innovative & -0.61 & -0.65 & -0.78 & 121 \\
\hline Organizationally oriented innovators & -0.81 & -0.33 & 0.89 & 103 \\
\hline Marketing-oriented innovators & 1.41 & 0.12 & -0.74 & 89 \\
\hline Technological innovators & -0.69 & 1.30 & -0.44 & 78 \\
\hline Non-technological innovators & 1.09 & -0.69 & 1.19 & 60 \\
\hline All-round innovators & 0.78 & 1.60 & 1.19 & 26 \\
\hline
\end{tabular}

literature that technological and organizational change will necessarily go hand-in-hand. If there are such relationships, the data suggests that there are lags of various sorts involved, so the innovations do not happen simultaneously.

The first factor, which we label "Marketing", involves innovation activities dealing with marketing and communication. We interpret this factor as those activities aimed at attracting new clients and retaining existing ones, promoting services, and maintaining relationships with customers (and other partners). A study of innovation patterns across a wider range of services in Poland [Szczygielsk, Grabowski, 2014] arrived at a similar conclusion as to such a distinctive marketing factor. There is no substantial association between the measures of client demand and this factor. It is plausible that KIBS firms that are experiencing growing customer demand are not encouraged to engage in new marketing efforts. The second factor, which we label "Technologies and Scale", reflects companies' focus on technological innovations. Our data does not distinguish between product and process innovations (both are regarded as technological), but the result appears consistent with those of Rodriguez and Camacho [Rodriguez, Camacho, 2010] who identify a factor that reflects companies' orientation towards product innovation. In addition, our factor relates also to customers' innovation activity: innovative clients require more and, to a lesser extent, a wider range of services from KIBS. Technologically innovative KIBS firms seem to be subject to demand from such clients, which suggests that innovative customers, having their own new products and processes, require more services to support these. Technological innovation may be used by a KIBS firm to extend its scale of operation and to support the introduction of new services. Finally, the third factor is labeled "Organizational Changes and Customization", since it brings together the application of organizational innovations on the part of the KIBS firm, with innovative customers requiring a wider range of services and, in particular, more customized services. A factor that described companies' focus on organizational innovations was also identified in the course of analyzing the Italian KIBS sector [Corrocher et al., 2009].

Factor analysis reduces the number of variables but does not reveal their distribution at the corporate level [Doloreux, Shearmur, 2013], thus creating the need for further analysis. The k-means clustering technique was applied with the so-called "elbow rule" determining the optimal number of clusters (at the level after which a distinctive break of the scree plot occurs) [Mooi, Sarstedt, 2011]. Six clusters were identified, which represent groups of companies with relatively similar innovative characteristics (Table 3 ).

The non-innovative companies cluster was the largest, about $25 \%$ of the total sample of firms that report little innovation of any type. ${ }^{9}$ Such a cluster was also identified over the course of European studies of KIBS [Asikainen, 2015] and is found in studies of innovation configurations in many sectors. ${ }^{10}$

The organizationally oriented innovators cluster comprises companies that use organizational innovations and whose customers, as they step up their own innovation activity, demand increasingly customized services. Companies in this cluster achieve low scores in terms of technological innovation, and even more so in terms of marketing or communication. Marketing-oriented innovators tend to actively apply the latter but in turn do not apply organizational innovations (and are not distinguished in terms of technological innovation).

In contrast, firms in the technological innovators cluster apply exclusively product and process innovations and do not create or use marketing ones. Some international studies put companies oriented only towards product innovations (a subset of technological innovations) into a specific cluster of their own [Camacho, Rodriguez, 2008]. The non-technological innovators cluster comprises companies specializing in marketing, communication, and organizational innovations, similar to the ones presented in [Rodriguez, Camacho, 2010].

\footnotetext{
${ }^{9}$ This figure is somewhat larger than the indicator listed in Figure 1 as not undertaking innovations, since the factor scores used in this part of the analysis also take demand into account.

${ }^{10}$ It is worth noting that the share of Russian manufacturing companies that are innovative also remains modest [Gokhberg at al., 2010].
} 
Figure 2. Distribution of KIBS firms across clusters $(\%)$

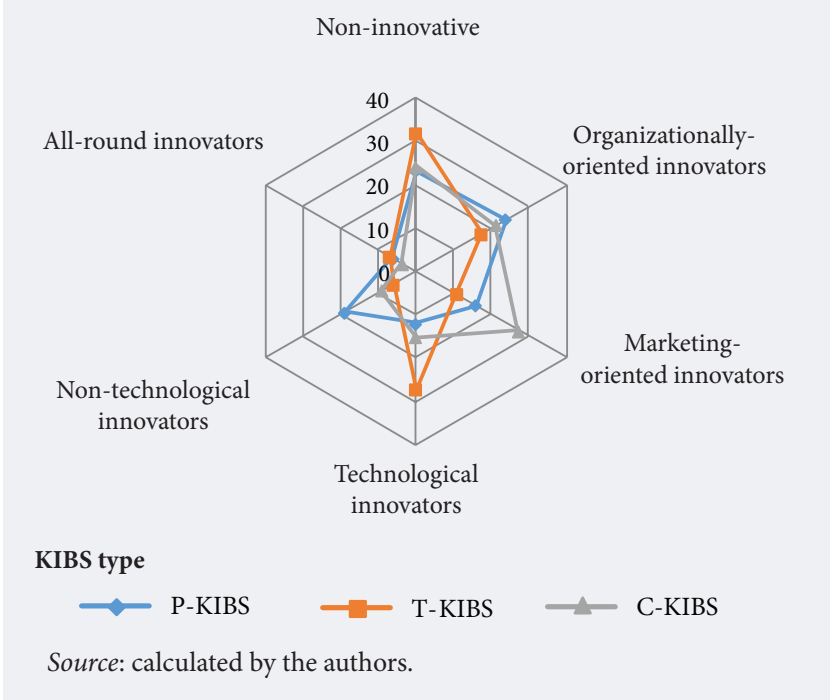

Figure 3. Company clusters' shares by company relative size $(\%)$

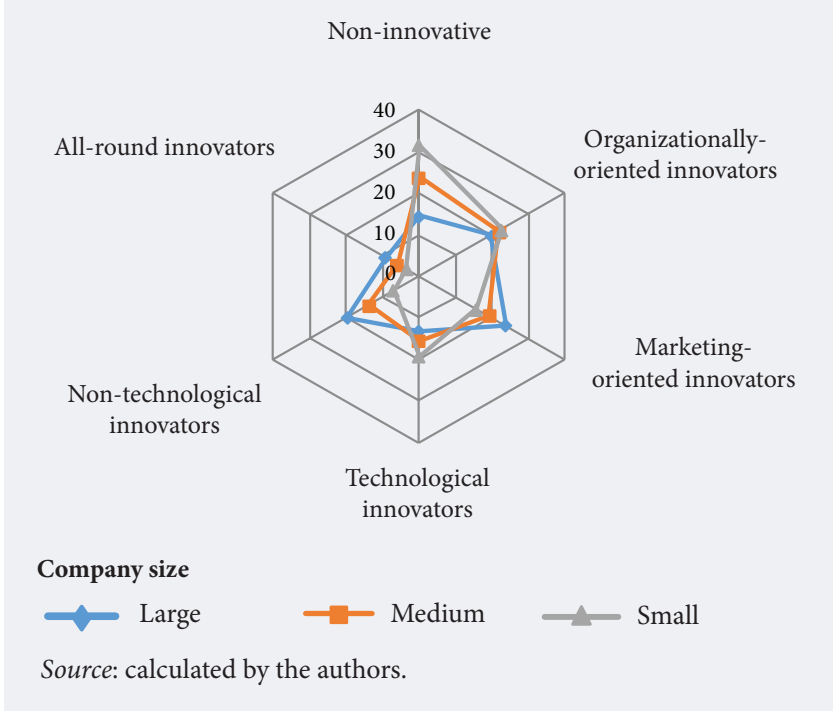

Finally, the all-round innovators cluster is the smallest one (just over $5 \%$ of the respondents). Companies in this group apply all of the above innovation types - technological, marketing, organizational, and communication ones. Indicators such as organizational change and customization (1.19) and technologies and scale (1.60) tend to have higher values in this cluster than in those specializing in the aforementioned relevant innovation types (organizationally oriented ( 0.89 for the first factor) and technological innovators ( 1.30 for the second factor), respectively). With many types of innovation being reported, we can expect that these companies display very high levels of innovation activity and quite possibly are ones that are changing their business models.

Now, membership in these clusters is quite likely to be related to the sorts of knowledge that a particular type of KIBS employs. We can examine how different broad classes of KIBS firm fall into the six clusters identified above. It could be expected that industries providing services with properties that are more material, and closer to those of goods (e.g., computer software), tend to display more technological innovations unlike those producing less tangible (and often more unique) services (e.g., consulting firms) [Doloreux, Shearmur, 2010]. Similar results were obtained by Amara et al. [Amara et al., 2016] who reported that firms operating in technology-based industries are more likely to be the developers of process innovations than their counterparts from traditional professional industries. However, the latter more frequently implements strategic innovations. Figure 2 depicts the distribution of P-KIBS, T-KIBS and C-KIBS ${ }^{11}$ across the clusters.

As we would expect, T-KIBS are particularly active as technological innovators, though a surprising share of these firms are not active innovators. This suggests that these firms are primarily engaged in rather basic technology transfer and, perhaps, in some minor customization activity for standard products to meet specific client needs. There are also very few of these firms in the "non-technological" cluster, which tends to attract the other types of KIBS (The firms undertaking two of the innovation types thus appear to be combining organizational and marketing innovations). The T-KIBS firms do fairly often employ organizational innovations without technological innovations. Presumably such firms have established services that they are coming to produce through new organizational forms, for example, to work on a larger scale. Note too that there are a number of all-round innovators who are T-KIBS.

A smaller, but still substantial, share of companies specializing in professional business services (P-KIBS) are also non-innovative. Among the innovative P-KIBS, organizationally oriented innovators are the most numerous, while relatively few report focusing on technological innovation (non-technological and marketing innovators are more common). This is not so surprising given that their knowledge base is more a matter of social and administrative systems. In the future, it may well be that new technologies, such as those related to data analytics, will make inroads into professional services ${ }^{12}$, but this has yet to happen in Russia.

Innovative providers of creative business services (C-KIBS) resemble P-KIBS in many ways, but strikingly feature a large share of firms who develop and apply marketing and communication innovations, and who combine this with organizational innovations. We can interpret this as confirming that customers

${ }^{11} \mathrm{P}$-KIBS include audit, HR consulting, financial intermediation, legal services and property development services; T-KIBS include information technologies and engineering; advertising, marketing and design are considered C-KIBS.

${ }^{12} \mathrm{Cf}$ [Susskind, Susskind, 2015]. 
play an important role in the use of such companies' innovations [Marasco et al., 2011], but further study would be required to explain their low presence in the "non-technological" cluster.

We can further examine the propensity to fall into one or another cluster by seeing how it relates to the various company sizes studied in the survey, ${ }^{13}$ which revealed several patterns (Figure 3 ).

Most notably, the firms who assessed their companies as small in relation to the rest of the market had a larger share of non-innovative companies, but a much smaller share of firms with the all-round innovator profile. It is common in innovation surveys to find that firm size is positively correlated with the propensity to undertake innovations. It is interesting to note that here the tendency appears to be for (relatively) smaller firms to more commonly to avoid undertaking multiple innovations. They actually tend to pursue technological innovations more often than larger firms. It is possible that we see here more young companies with less need to work on restructuring their marketing or organizational features.

It is the relatively large firms that are the least likely to enter the non-innovator cluster, and more likely to be all-round or non-technological innovators than medium and small firms. Otherwise, relatively large and medium-sized firms have fairly similar profiles.

\section{Conclusions}

We have analyzed the innovation activities of Russian KIBS companies. The KIBS industries are widely recognized to be important in terms of their own innovations and their support in helping foster innovation in client industries. They are, however, very heterogeneous and there is great need to deepen our understanding about the types of innovations they undertake. A detailed analysis of their innovation patterns and strategies could be useful for government efforts to promote industrial innovation. Failing to identify and explain the varied innovation profiles may undermine the efficacy of relevant policies.

The bulk of the sample in the survey reported here consists of small and medium-sized enterprises, as is typical of KIBS and many other services. The first point to make is that the majority of firms were innovative in one way or another and actually reported one or more innovations in the previous year. While a sizeable number of firms (especially the smaller firms) did not report innovation activity, several different patterns emerged concerning those who engaged in one or more types of innovation. We found that innovation clusters vary not just in terms of the type of innovation, but also in terms of the relationship between the demand for knowledge-intensive business services and customers' own innovation activity in terms of the amount, range, and degree of customization of the services they procure. A comparative analysis of companies belonging to different KIBS segments (P-, T-, and $\mathrm{C}$-KIBS) and operating on different scales (in their own estimation of size relative to other firms in their sector) allowed us to group them into the following clusters: non-innovative companies, organizationally oriented, marketing-oriented, non-technological, technological, and all-round innovators.

It was demonstrated that relative size matters. For example, as KIBS companies' assessment of their own size in relation to the market grows, the share of all-round innovators among them also increases, and that of non-innovators diminishes. The clusters are not industry-specific: in each of the clusters, including non-innovators and all-round innovators, P-KIBS, T-KIBS, and C-KIBS firms are represented. There are, however, differences in their propensity to engage in certain innovative activities. Thus, T-KIBS companies are largely concentrated in the technological innovators cluster, C-KIBS firms in the cluster specializing in marketing and communication innovations, and P-KIBS predominantly use organizational innovations.

Further research would help overcome the limitations of our study and provide a deeper understanding of KIBS companies' innovation mechanisms. Different aspects of innovation activities were beyond the purview of this study (expenditures on different functions, the use of different sources of information, the involvement of clients in co-production, and so on) and should be examined. Different types of innovation can be examined in terms, for example, of the degree of novelty (to the firm/sector/world; whether it is radical or incremental, etc.). The scope for differentiating between product (new service) and process innovation should be explored. Barriers to innovation, and drivers of activity, can also be considered, and may be of particular interest to policymakers. We have speculated about the reasons for the distinct relationships that emerge between different types of client demand and different types of innovation on the part of the KIBS firms. More investigation is required to establish the causal processes behind these correlations. While further study is certainly necessary, this essay has, hopefully, contributed to the exploration of distinctive patterns of innovation in this important, but rather neglected, part of the economy.

The article was prepared within the framework of the Basic Research Program at the National Research University Higher School of Economics (HSE) and supported within the framework of a subsidy by the Russian Academic Excellence Project '5-100'. The authors gratefully acknowledge the valuable comments and suggestions by Sergey Shvydun (HSE).

\footnotetext{
${ }^{13}$ We relied on the respondents' estimates of their company size in relation to the market. This approach was chosen due to the great heterogeneity in KIBS. For example, in 2013, the recruitment and personnel management services market was estimated at 18-35 billion rubles, the audit and managerial consulting services market at 81 billion rubles, the legal services market at 160-200 billion rubles, and the advertising market at 419 billion rubles [Berezin, 2016].
} 


\section{References}

Amara N., Landry R., Doloreux D. (2009) Patterns of innovation in knowledge-intensive business services. The Service Industries Journal, vol. 29, no 4, pp. 407-430.

Amara N., Landry R., Traore N. (2008) Managing the protection on innovations in knowledge-intensive business services. Research Policy, vol. 37, no 9, pp. 1530-1547.

Amara N., D'Este P., Landry R., Doloreux D. (2016) Impacts of obstacles on innovation patterns in KIBS firms. Journal of Business Research, vol. 69, no. 10, pp. 4065-4073.

Asikainen A.-L. (2015) Innovation modes and strategies in knowledge intensive business services. Service Business, vol. 9, no 1, pp. 77-95.

Berezin I. (2016) Ekspertnye otsenki ob"ema i dinamiki rynkov intellektual'nykh uslug v Rossii 2005-2015 [Expert assessment of the amount and dynamics of intellectual services markets in Russia 2005-2015]. Marketing v Rossii 2016. Spravochnik Gil'dii Marketologov [Marketing in Russia 2016. Marketers Guild Guide] (ed. I. Berezin), Moscow: Marketers Guild, pp. 33-69 (in Russian).

Berezin I., Doroshenko M. (2015) Kolichestvennye i kachestvennye izmeneniya na rynke intellektual'nykh uslug v Rossii 2005-2013 [Quantitative and qualitative changes on the market on intellectual services in Russia in 2005-2013]. Marketing v Rossii 2015 [Marketing in Russia 2015] (ed. I.S. Berezin). Moscow: Marketers Guild, pp. 85-128.

Camacho J.A., Rodriguez M. (2008) Patterns of innovation in the service sector: Some insights from the Spanish innovation survey. Economics of Innovation and New Technology, vol. 17, no 5, pp. 459-471.

Corrocher N., Cusmano L., Morrison A. (2009) Modes of innovation in knowledge-intensive business services evidence from Lombardy. Journal of Evolutionary Economics, vol. 19, no 2, pp. 173-196.

den Hertog P. (2000) Knowledge-intensive business services as co-producers of innovation. International Journal of Innovation Management, vol. 4, no 4, pp. 491-528.

Doloreux D., Shearmur R. (2010) Exploring and comparing innovation patterns across different knowledge intensive business services. Economics of Innovation and New Technology, vol. 19, no 7, pp. 605-625.

Doloreux D., Shearmur R. (2013) Innovation strategies: Are knowledge-intensive business services just another source of information? Industry and innovation, vol. 20, no 8, pp. 719-738.

Fang H., Zhao T., Zhang Y.Q. (2016) Research on the Interaction of China's Knowledge-Intensive Business Services and Manufacturing Upgrading. Paper presented at the 2016 Joint International Conference on Economics and Management Engineering (ICEME 2016) and International Conference on Economics and Business Management (EBM 2016). Available at: http://goo.gl/6oGc3r, accessed 14.05.2017.

Freel M. (2006) Characterising innovations in knowledge-intensive business services. Advances in Entrepreneurship, Firm Emergence and Growth (eds. J. Katz, A.C. Corbett), vol. 9, pp. 147-174.

Freel M. (2010) Knowledge-Intensive Business Services users and uses: Exploring the propensity to innovation-related cooperation with Knowledge-Intensive Business Services. Knowledge-intensive business services: geography and innovation (eds. D. Doloreux, M. Freel, R. Shearmur), Burlington, VT: Ashgate, pp. 75-98.

Gokhberg L., Kuznetsova T., Roud V. (2010) Analiz innovatsionnykh rezhimov v rossiiskoi ekonomike: metodologicheskie podkhody i pervye rezul'taty [Analysis of Innovation Modes in the Russian Economy: Methodological Approaches and First Results]. Foresight-Russia, vol. 4, no 3, pp. 18-30 (in Russian)

Gotsch M., Hipp C., Gallego J., Rubalcaba L. (2011) Sectoral Innovation Watch. Knowledge Intensive Services Sector (Europe Innova Final Report, December 2011), Brussels: European Commission. Available at: http://www.praxis.ee/wp-content/ uploads/2014/03/sector-report-knowledge en.pdf, accessed 27.06.2017.

Janger J., Schubert T., Andries P., Rammer C., Hoskens M. (2017) The EU 2020 innovation indicator: A step forward in measuring innovation outputs and outcomes? Research Policy, vol. 46, no 1, pp. 30-42.

Keeley L., Walters H., Pikkel R., Quinn B. (2013) Ten types of innovation: The discipline of building breakthroughs, New York: John Wiley \& Sons.

Landry R., Amara N., Doloreux D. (2012) Knowledge-exchange strategies between KIBS firms and their clients. The Service Industries Journal, vol. 32, no 2, pp. 291-320.

Marasco A., Masiello B., Izzo F. (2011) Customer interaction and innovation in Creative-Intensive Business Services: A framework for exploring co-innovation in advertising agency-client relationships. Paper presented at the Reser 2011 Conference "Productivity of Services Next Gen-Beyond Output/Input", 07-10 September 2011. Available at: http://reser.net/materiali/priloge/slo/marasco_ et_al.pdf, accessed 24.03.2017.

Masiello, B., Marasco, A., Izzo, F., and Amato, U. (2014) Exploring Clients' Role in the Innovation of Advertising Services: A European Survey 21st IPDM Conference - "Innovation through Engineering, Business and Design", Limerick, Ireland, June 15-17, 2014. Available from: https://www.researchgate.net/publication/276936668 EXPLORING_CLIENTS\%27 ROLE_IN THE INNOVATION_OF_ADVERTISING_SERVICES_A_EUROPEAN_SURVEY (accessed Aug 26.08.2017).

Miles I. (2012) KIBS and Knowledge Dynamics in Client-Supplier Interaction. Exploring Knowledge-Intensive Business Services: Knowledge Management Strategies (ed. E. di Maria), London; New York: Palgrave Macmillan, pp. 13-34.

Miles I., Kastrinos N., Bilderbeek R., den Hertog P., Flanagan K., Huntink W., Bouman M. (1995) Knowledge-intensive business services: Users, carriers and sources of innovation (European Innovation Monitoring System (EIMS) Report). Brussels: European Commission.

Miozzo M., Desyllas P., Lee H., Miles I. (2016) Innovation collaboration and appropriability by knowledge-intensive business services firms. Research Policy, vol. 45, no 7, pp. 1337-1351.

Mooi E., Sarstedt M. (2011) A Concise Guide to Market Research. The Process, Data, and Methods Using IBM SPSS Statistics, Heidelberg; New York; Dordrecht; London: Springer.

OECD (2017) STAN: OECD Structural Analysis Statistics 2016, Paris: OECD. Available at: http://dx.doi.org/10.1787/stan-2016-en, accessed 15.06.2017.

OECD, Eurostat (2005) Oslo Manual: Guidelines for Collecting and Interpreting Innovation Data (3rd ed.), Paris: OECD, Eurostat.

Pinto H., Fernandez-Esquinas M., Uyarra E. (2015) Universities and knowledge-intensive business services (KIBS) as sources of knowledge for innovative firms in peripheral regions. Regional Studies, vol. 49, no 11, pp. 1873-1891.

Rodriguez M., Camacho J.A. (2010) Are knowledge-intensive business services so "hard" innovators? Some insights using Spanish microdata. Journal of Innovation Economics \& Management, vol. 1, no 5, pp. 41-65.

Rodriguez M., Doloreux D., Shearmur R. (2015) Innovation strategies, innovator types and openness: A study of KIBS firms in Spain. Service Business, vol. 3, pp. 1-21. DOI 10.1007/s11628-015-0286-x. Available at: https://www.springerprofessional.de/ innovation-strategies-innovator-types-and-openness-a-study-of-ki/10902094, accessed 08.02.2017.

Santos-Vijande M.L., López-Sánchez J.Á., González-Mieres C. (2012) Organizational learning, innovation, and performance in KIBS. Journal of Management \& Organization, vol. 18, no 6, pp. 870-904.

Schnabl E., Zenker A. (2013). Statistical Classification of Knowledge-Intensive Business Services (KIBS) with NACE Rev. 2 Karlsruhe: Fraunhofer Institute for Systems and Innovation Research ISI, evoREG Research Note 25.

Schricke E., Zenker A. and Stahlecker T. (2012) Knowledge-intensive (business) services in Europe, Brussels: European Commission.

Susskind R., Susskind D. (2015) The Future of the Professions: How Technology Will Transform the Work of Human Experts. Oxford: Oxford University Press.

Szczygielski K., Grabowski W. (2014) Innovation strategies and productivity in the Polish services sector. Post-Communist Economies, vol. 26, no 1, pp. 17-38.

Wyrwich M. (2013) The Role of Regional Conditions for Newly Emerging KIBS Industries in the Face of Radical Institutional Change. European Planning Studies, vol. 21, no 11, pp. 1760-1778. 


\title{
Eco-Innovation and Firm Efficiency: Empirical Evidence from Slovenia
}

\author{
Jana Hojnik ${ }^{\text {a }}$ \\ Assistant Professor, Faculty of Management, jana.hojnik@fm-kp.si \\ Mitja Ruzzier ${ }^{a}$ \\ Professor, Faculty of Management, mitja.ruzzier@fm-kp.si \\ Tatiana Manolova ${ }^{b}$ \\ Associate Professor, tmanolova@bentley.edu \\ ${ }^{a}$ University of Primorska, Cankarjeva 5, 6000 Koper, Slovenia. \\ b Bentley University, 175 Forest St., Waltham, MA 02452, USA.
}

\begin{abstract}
$\mathrm{E}$ co-innovation plays an increasingly important role for the competitiveness of companies. It opens up new market opportunities due to the growing demand for eco-friendly products and can increase business efficiency. Using a dynamic capabilities lens, this article analyzes the relationships between various types of eco-innovation (product, process and organizational) and firm efficiency in the context of less innovative and more innovative companies. We use data from an online survey of Slovenian companies that have implemented eco-innovations as part of their operations. Statistical tests include an analysis of variance and a linear regression analysis.

We find that organizational eco-innovation positively affects firm efficiency at all companies independent of their innovation potential, while process eco-innovation is positively associated with firm efficiency only among more innovative companies. In addition, at less innovative

companies, firm age positively affects firm efficiency, suggesting that older and less innovative companies may enjoy learning curve benefits derived from experience. However, firm size has a positive effect on firm efficiency at more innovative companies, suggesting that more innovative companies may benefit from economies of scale. In general, more innovative companies are more likely to engage in eco-innovation and more likely to derive cost benefits (efficiency) from different types of eco-innovation.

The main limitations of our analysis are the subjective data on the level of firms' innovation and efficiency, the cross-sectional study design, and the single-country setting. Further in-depth longitudinal studies could better model the direction of causality between the implementation of eco-innovation and business efficiency, obtain objective data on business innovation, and ensure a more detailed and nuanced exploration of dynamic firm capabilities.
\end{abstract}

Keywords: eco-innovation; circular economy; firm efficiency; product eco-innovation; process eco-innovation; organizational eco-innovation; sustainability; more innovative companies; less innovative companies; Slovenia.
Citation: Hojnik J., Ruzzier M., Manolova T. (2017) EcoInnovation and Firm Efficiency: Empirical Evidence from Slovenia. Foresight and STI Governance, vol. 11, no 3, pp. 103-111. DOI: 10.17323/2500-2597.2017.3.103.111 
$\mathrm{T}$ o pursue and achieve environmental sustainability, companies around the world increasingly engage in eco-innovation. Eco-innovation is defined as the "introduction of any new or significantly improved product (good or service), process, organizational change or marketing solution that reduces the use of natural resources (including materials, energy, water and land) and decreases the release of harmful substances across the lifecycle" [European Commission, 2012, p. 8]. Eco-innovations facilitate the transition from a traditional or "linear" economy to an environmentally sustainable, "circular" economy. The circular economy is grounded in the three " $R$ " principles-Reduce, Reuse and Recycle [Bourguignon, 2016; Ness, 2008; Su et al., 2013]. It promotes the adoption of closed-loop and cleaner production processes and increases the efficiency of resource use in order to achieve a better balance between and harmony among the three pillars of sustainability: economy, environment and society [Ghisellini et al., 2016]. Eco-innovations cannot be implemented successfully without environmental awareness and environmental responsibility on the part of both producers and consumers. Ample prior research demonstrates that both companies' environmental consciousness and customers' purchasing choices are needed in order to facilitate the transition to a more circular economy [Agan et al., 2013; Hojnik, Ruzzier, 2016b; Horbach et al., 2012; Li, 2014] $]^{1}$.

Although both consumers and producers are important stakeholders in the adoption of eco-innovation, there is tension in the process of creating and capturing environmental, social, and economic value. This is because the creation of customer value through eco-innovation does not guarantee the capture of economic value by the producer. Many consumers clearly derive tangible and intangible benefits from eco-innovations. Increasingly consumers are looking for environmentally friendly alternatives and are willing to pay higher prices for such products [Chen, 2013]. Thus, producers are expected to provide proper design, production, sales and recycling in order to meet consumers' demands for "green" products [Sarkar, 2013]. Consumers not only push companies to act in an environmentally responsible manner but also expect to reap private environmental benefits from eco-products such as cost and energy savings; improved product quality and durability; better repair, upgrade and disposal opportunities; and reduced health risks [Kammerer, 2009].

The effect of eco-innovation on producers' performance is far less clear. On the one hand, companies engaged in eco-innovation can derive cost savings by reducing raw material usage and energy dependency, which increases efficiency and improves competitiveness [EASAC, 2015]. The opportunity to realize cost savings (e.g., energy or material savings) is indeed one of the main reasons for investing in eco-innovations [Belin et al., 2011; Govindan et al., 2014; Horbach, 2008; Montabon et al., 2007). On the other hand, firm efficiency depends upon the type of eco-innovation, as only the most advanced eco-innovations will have the potential to generate cost savings and add to firm efficiency [Kesidou, Demirel, 2012]. In light of these tensions, we ask: (1) What specific types of companies are more likely to invest in eco-innovation? (2) What is the effect of different types of eco-innovation (i.e., product, process, and organizational) on firm efficiency?

To develop our theoretical argument, we build upon the dynamic capabilities perspective [Eisenhardt, Martin, 2000; Teece et al., 1997), which is an extension of the resource-based view [Piening, Salge, 2015; Wernerfelt, 1984]. We follow Teece et al's definition of dynamic capabilities as a firm's "ability to integrate, build, and reconfigure internal and external competences to address rapidly changing environments." [Teece et al., 1997, p. 516]. Our main premise is that more innovative companies are also more likely to engage in eco-innovation, as they already have developed capabilities for innovation. Furthermore, we expect that eco-innovation is more likely to lead to improved efficiency among more innovative companies. Our main contribution is an exploration of the effects of different types of eco-innovation (product, process and organizational) upon firm efficiency. In addition, we take a fine-grained approach and explore these effects in two sub-samples - more and less innovative companies - in order to provide more detailed insights into eco-innovation's effects on firm efficiency. Empirically, we contribute by documenting eco-innovation practices and their effect on firm efficiency in the context of Slovenia, a country that has successfully made the transition to an innovation-driven economy [WEF, 2016].

Slovenia provides a very appropriate study subject because it is both entrepreneur-friendly and environmentally-conscious. According to the latest GEM (Global Entrepreneurship Monitor) report, the level of perceived entrepreneurial opportunities in the country shows an upward trend. Slovenia also ranks high ( $22^{\text {nd }}$ out of 60 surveyed countries) with respect to the societal values concerning entrepreneurship, i.e., entrepreneurs are accorded high social status [GEM, 2016]. Slovenia ranks $15^{\text {th }}$ out of 139 countries in environmental performance, $12^{\text {th }}$ out of 138 in the number of ISO14001 environmental certificates issued, and $28^{\text {th }}$ out of 141 in the Global Innovation Index rankings [Dutta et al., 2016]. Thus, innovation, including eco-innovation, is becoming an indispensable part of Slovenian companies' strategies to survive and achieve a competitive advantage [Adalikwu, 2011].

Our paper proceeds as follows. In the next section, we set up the theoretical background and develop our research hypotheses. Then, we describe the study's methodology and sample characteristics and variables. The subsequent section reports upon the results, while the final section discusses this paper's implications for theory and practice.

\footnotetext{
See also the extensive literature review by [Hojnik, Ruzzier, 2016a].
} 


\section{Theoretical background and research hypotheses}

We grounded our argument in the dynamic capabilities perspective. Firm-level capabilities are conceptualized as the ability of a firm to perform an activity with predictable efficiency over time [Nelson, Winter, 1982]. Examples of firm-level capabilities include innovation, marketing, logistics, and customer service. Because capabilities are "invisible assets", and because some of the learning is difficult to articulate and transfer to other organizations [Teece, 1981], capabilities are firm-specific and are likely to provide a firm with a source of competitive advantage [Barney, 1991].

The capability view of a firm has been extended to the context of dynamic environments, with the idea that said firm's capabilities must be dynamic: companies must constantly adapt, reconfigure and renew their resources and capabilities in order to address environmental change and achieve congruence with the changing business environment [Teece et al., 1997]. Therefore, dynamic capabilities have been defined as the company's potential to systematically solve problems, sense opportunities and threats, make timely decisions, and implement strategic decisions and changes efficiently to ensure that the company is following the right path [Li, Liu, 2014, p. 2793]. Dynamic capabilities are thus related to organizational change that promotes innovation and, as a result, improves the company's evolutionary fitness [Makkonen et al., 2014]. The dynamic capabilities perspective garnered much attention because a resource-based strategy grounded on the simple accumulation of valuable assets/resources, protected by an aggressive intellectual property stance, proved inadequate to support a significant competitive advantage [Teece et al., 1997]. To be globally competitive, companies need to demonstrate responsiveness and rapid, flexible product innovation, coupled with the management capability to effectively coordinate and redeploy market positions and expansion paths [Teece et al., 1997].

Applying the dynamic capability perspective to the context of eco-innovation, we can expect that these companies that have already developed a firm-level innovation capability to find it easier to engage in ecoinnovation. This is because these companies already have innovation experience, well-established routines, and task-management processes in place. In addition, firms that have innovation capabilities are likely to have developed the skills to articulate, codify, share, and internalize innovation-related knowledge, which can be successfully transferred and used for the launch of eco-innovations. Formally, we hypothesize:

Hypothesis 1: More innovative companies will demonstrate higher levels of eco-innovation compared to less innovative companies.

Cost savings are among the main reasons for companies to invest in eco-innovation [Belin et al., 2011; Horbach, 2008]. Eco-innovation and better environmental performance can lead to the reduction of several expenditures, especially in the following areas: cost of materials, energy and services; cost of capital; cost of labor; risk management and relations with external stakeholders [Ambec, Lanoie, 2008]. Based on a study of SMEs, Klewitz [Klewitz, 2012] found that companies can benefit from cost savings (increased energy efficiency) when dealing with sustainability-related issues. Large financial gains can thus be derived from energy and material saving, waste reduction, and addressing lifecycle costs [Shrivastava, 1995]. Environmental management practices associated with cost savings include recycling (more efficient use of materials tends to reduce the cost structure), proactive waste reduction, and remanufacture (both focus on lowering cost structure) [Montabon et al., 2007]. Companies have acknowledged that reuse leads to lower costs (i.e., instead of purchasing new materials, they reuse materials and thus are able to lower costs) [Govindan et al., 2014]. However, not all eco-innovations pay off. Cost savings associated with firm efficiency, which can be attained through the successful implementation of eco-innovation, depend upon the type of eco-innovation. This means that cost savings are most closely associated with the most advanced ecoinnovations, which encompass the elimination/reduction or reuse of material waste, while less advanced eco-innovations have a lower potential for creating cost savings and contributing to firm efficiency [Kesidou, Demirel, 2012]. Although empirical results are mixed, the majority of research points out the significance of cost savings for process eco-innovations [Triguero et al., 2013]. In addition, environmental technologies have the potential to decrease operating costs by exploiting ecological efficiencies [Shrivastava, 1995]. Overall, companies that focus on green product, process and managerial innovations are likely to increase their savings, efficiency, and productivity [Chiou et al., 2011]. Formally, we hypothesize:

Hypothesis 2: Eco-innovation will positively impact firm efficiency.

\section{Methodology \\ Data collection and sample}

The main objective of this study is to explore the relationship between different types of eco-innovation (product, process and organizational eco-innovations) and firm efficiency. Data on specific types of ecoinnovation at the firm level are usually not available from published sources. To overcome this difficulty, we used a survey (an e-mail questionnaire distributed to environmental managers and directors of Slovenian companies that use eco-innovations within their entrepreneurial activity), which we sent out in November 2014. The survey was e-mailed along with a cover letter explaining the general purpose of the study, and anonymity was guaranteed in order to increase the response rate. A comprehensive literature review was undertaken prior to designing the survey instrument to ensure the reliability and validity of the measures. 
In addition, prior to data collection, the survey was pre-tested for content validity. First, eight experienced researchers were asked to critique the questionnaire for ambiguity, clarity and appropriateness of the used terminology. Second, we asked five environmental managers to discuss the questionnaire, comment on term appropriateness and identify any vagueness. Based on their feedback, the questionnaire was adjusted. Over a three-month period (November 2014 through February 2015) and after three reminders, we collected 223 completed questionnaires out of the 6,564 companies to which we sent the questionnaire, resulting in a response rate of $3.40 \%$. A low response rate was expected, since the questionnaire was only available online and only companies that engage in eco-innovation activities were asked to respond (in order to avoid excluding any companies that are active in eco-innovation, the questionnaire was sent to the entire population of companies).

As we discuss in more detail below, the sample was next divided into two sub-samples: more innovative companies $(\mathrm{N}=125$ companies $)$ and less innovative companies $(\mathrm{N}=98$ companies $)$. Table 1 reports the characteristics of the two sub-samples.

The two sub-samples differ in size distribution. ${ }^{2}$ The subsample of less innovative companies includes more micro companies (32 companies) and fewer large companies (14 companies), while in the subsample of the more innovative companies the situation is reversed (there are 33 large companies and only 20 micro companies). The majority of the companies in both sub-samples are 20 or more years old. With respect to industry distribution, more innovative companies are predominantly in manufacturing, while less innovative companies operate mainly in service-related industries. All companies in the analyzed sample deploy some sort of eco-innovation, however, the more innovative companies are more likely to have garnered environmental certificates (EMAS or ISO14001).

\section{Variables}

Both the dependent and independent variables are measured using multi-item scales. Prior to running the regression calculations, we ascertained the validity and reliability of the measurement model using factor and reliability analysis. We factor-analyzed each of our independent variables, i.e., eco-innovation type (e.g., product, process, or organizational eco-innovation) and our dependent variable, firm efficiency (the extraction method was Maximum Likelihood, and the rotation was Direct Oblimin).

Product eco-innovation was measured using a six-item, seven-point Likert-type scale, adapted from [Chen et al., 2006; Chen, 2008; Chiou et al., 2011] and ranging from 1 ("strongly disagree") to 7 ("strongly agree"), with 4 as the neutral anchor. We first conducted an exploratory factor analysis, which showed that all six items loaded on a common factor - product eco-innovation. The value of the Kaiser-Meyer-Olkin (KMO) measure for sampling adequacy was 0.846 , which can be interpreted as excellent, because it is above 0.80 and suggests that there are high enough correlations between variables for suitable use of factor analysis. In addition, Bartlett's test of sphericity showed a statistically significant value (chi-square $=712.159$;

Table 1. Sample characteristics

\begin{tabular}{|c|c|c|c|c|c|}
\hline & \multirow{3}{*}{ Characteristics } & \multicolumn{4}{|c|}{ Firm's Innovativeness Level } \\
\hline & & \multicolumn{2}{|c|}{ Low (98 companies) } & \multicolumn{2}{|c|}{ High (125 companies) } \\
\hline & & $\begin{array}{l}\text { Number of } \\
\text { companies }\end{array}$ & Percentage & $\begin{array}{l}\text { Number of } \\
\text { companies }\end{array}$ & Percentage \\
\hline \multirow{4}{*}{ Firm size } & Micro company & 32 & 32.7 & 20 & 16 \\
\hline & Small company & 30 & 30.6 & 38 & 30.4 \\
\hline & Medium company & 22 & 22.4 & 34 & 27.2 \\
\hline & Large company & 14 & 14.3 & 33 & 26.4 \\
\hline \multirow{4}{*}{ Firm age } & 3 years or fewer & 1 & 1 & 3 & 2.4 \\
\hline & 4-9 years & 9 & 9.2 & 6 & 4.8 \\
\hline & $10-19$ years & 21 & 21.4 & 18 & 14.4 \\
\hline & 20 years and more & 67 & 68.4 & 96 & 76.8 \\
\hline \multirow{2}{*}{ Type of industry } & Service industry & 79 & 80.6 & 53 & 42.4 \\
\hline & Manufacturing industry & 19 & 19.4 & 72 & 57.6 \\
\hline \multirow{3}{*}{$\begin{array}{l}\text { Type of commerce } \\
\text { transactions }\end{array}$} & Business-to-business (B2B) & 58 & 59.2 & 55 & 44 \\
\hline & Business-to-customer (B2C) & 40 & 40.8 & 69 & 55.2 \\
\hline & Both (B2B and B2C) & - & - & 1 & 0.8 \\
\hline \multicolumn{2}{|c|}{ Internationalization (operating on foreign markets) } & 52 & 53.1 & 99 & 79.2 \\
\hline \multicolumn{2}{|c|}{ Have EMAS environmental certificate } & 1 & 1 & 3 & 2.4 \\
\hline \multicolumn{2}{|c|}{ Have ISO 14001 environmental certificate } & 28 & 28.6 & 58 & 46.4 \\
\hline
\end{tabular}

${ }^{2}$ We used the European firm size classification criteria, as follows: micro companies (fewer than 10 employees); small companies (10-49 employees); medium-sized companies (50-249 employees); and large companies (250 employees and above). See http:// ec.europa.eu/eurostat/statistics-explained/index.php/Glossary:Enterprise_size. 
$\mathrm{df}=15 ; \mathrm{p}=0.000$ ), meaning that the correlation matrix has significant correlations. The communality index showed good communalities for almost all items (above the threshold of 0.2 ), and the explained variance is estimated to be $55.245 \%$.

Five items measured process eco-innovation [Chen et al., 2006; Chen, 2008; Chiou et al., 2011]. The exploratory factor analysis also extracted a single factor, which explained $68.441 \%$ of total variance. The Kaiser-Meyer-Olkin measure for sampling adequacy $(\mathrm{KMO}=0.861)$ and Bartlett's test of sphericity (chisquare $=807.261 ; \mathrm{df}=10 ; \mathrm{p}=0.000)$ showed good results.

Six items were used to measure organizational eco-innovation [Cheng, Shiu, 2012]. The exploratory factor analysis extracted a single factor which explained $78.368 \%$ of the total variance. The Kaiser-Meyer-Olkin measure for sampling adequacy $(\mathrm{KMO}=0.901)$ and Bartlett's test of sphericity $($ chi-square $=1454.634 ; \mathrm{df}=$ $15 ; \mathrm{p}=0.000)$ also showed good results.

Following Sharma and Vredenburg [Sharma, Vredenburg, 1998], we measured efficiency (our dependent variable) with a six-item, seven-point Likert-type scale. An exploratory factor analysis was conducted, and regression factor scores were saved and used in further analysis, as for all eco-innovation types. The extraction method used was Maximum Likelihood, and the rotation was Direct Oblimin. The exploratory factor analysis for firm efficiency also extracted only one factor, explaining $71.637 \%$ of the total variance. The Kaiser-Meyer-Olkin measure for sampling adequacy $(\mathrm{KMO}=0.860)$ and Bartlett's test of sphericity (chi-square $=1275.002 ; \mathrm{df}=15 ; \mathrm{p}=0.000$ ) showed good results.

The results from the factor analysis are reported in Tables 2 and 3.

Since we are interested in whether more innovative companies are also more likely to develop eco-innovation, we introduced a grouping variable, "company innovativeness". We identified whether a company is more or less innovative based on the following three statements: 1) Company has launched a new product or service at the global level; 2) Company has launched a new product or service in the company's offering, even though similar products or services already exist on the market; and 3) Company has expanded the present offering with new types. Companies were asked to estimate to what extent the above statements held true for them (using a 7-point Likert-type scale, ranging from $1=$ not true at all to $7=$ completely true). We classified companies as more or less innovative by a median split of the sample (the three items were summed up and divided by three). In our regression estimations, we also controlled for firm size, firm age and type of industry.

\section{Table 2. Description of factor items and their loadings}

\begin{tabular}{|c|c|}
\hline Items & Factor item loadings \\
\hline \multicolumn{2}{|l|}{ Product eco-innovation } \\
\hline The company is using environmentally friendly materials & 0.888 \\
\hline The company is improving and designing environmentally friendly packaging for existing and new products & 0.866 \\
\hline The company is recovering the company's end-of-life products and recycling & 0.811 \\
\hline $\begin{array}{l}\text { The company chooses product materials that consume the least possible amount of energy and resources for } \\
\text { conducting product development or design }\end{array}$ & 0.659 \\
\hline $\begin{array}{l}\text { The company uses the smallest possible amount of materials to create the product for conducting product } \\
\text { development or design }\end{array}$ & 0.634 \\
\hline $\begin{array}{l}\text { The company deliberately evaluates whether the product is easy to recycle, reuse and decompose when } \\
\text { conducting product development or design }\end{array}$ & 0.532 \\
\hline \multicolumn{2}{|l|}{ Process eco-innovation } \\
\hline Low energy consumption of materials such as water, electricity, gas and petrol during production/use/disposal & 0.924 \\
\hline Recycle, reuse and remanufacture of materials & 0.909 \\
\hline Use of cleaner technology to generate savings and prevent pollution & 0.808 \\
\hline The manufacturing process of the company effectively reduces the emission of hazardous substances or waste & 0.758 \\
\hline The manufacturing process of the company reduces the use of raw materials & 0.716 \\
\hline \multicolumn{2}{|l|}{ Organizational eco-innovation } \\
\hline Our firm management often uses novel systems to manage eco-innovation & 0.930 \\
\hline Our firm management often collects information on eco-innovation trends & 0.929 \\
\hline Our firm management often actively engages in eco-innovation activities & 0.891 \\
\hline Our firm management often communicates about eco-innovation information with our employees & 0.888 \\
\hline Our firm management often invests substantially in R\&D on eco-innovation & 0.866 \\
\hline $\begin{array}{l}\text { Our firm management often communicates about experiences among various departments involved in eco- } \\
\text { innovation }\end{array}$ & 0.801 \\
\hline \multicolumn{2}{|l|}{ Firm efficiency } \\
\hline Reduction in material costs & 0.919 \\
\hline Reduction in process/production costs & 0.908 \\
\hline Increased process/production efficiency & 0.839 \\
\hline Increased productivity & 0.816 \\
\hline Increased knowledge about effective ways to manage operations & 0.812 \\
\hline Improved product quality & 0.774 \\
\hline
\end{tabular}


Table 3. General characteristics of factors

\begin{tabular}{|l|c|c|c|}
\hline \multicolumn{1}{|c|}{ Factors } & Number of factors extracted & Eigen- value & Cronbach's alpha \\
\hline Product eco-innovation & 1 & 3.735 & 0.866 \\
\hline Process eco-innovation & 1 & 3.739 & 0.912 \\
\hline Organizational eco-innovation & 1 & 4.919 & 0.956 \\
\hline Firm efficiency & 1 & 4.583 & 0.938 \\
\hline Source: compiled by the authors. & & \\
\hline
\end{tabular}

Before proceeding with the regression analysis, we checked for multicollinearity. We examined the Variance Inflation Factor (VIF), which is a widely used measure of the degree of multicollinearity of the $i$-th independent variable with the other independent variables in a regression model [O'Brien, 2007]. Various rules of thumb for values of VIF have appeared in the literature (rule of 4, rule of 10, etc.); however, when the VIF exceeds these values, these rules often are interpreted as casting doubt on the results of the regression analysis [O'Brien, 2007]. In our case, all VIF values were below the recommended threshold of 4, alleviating multicollinearity concerns (the highest VIF value was 2.539, and the lowest VIF value was 1.056).

Table 4 reports the means, standard deviations, and correlations for all variables entered into the regression analysis.

\section{Results}

We tested Hypothesis 1 by running an analysis of variance ( $t$ test). We found significant differences between less and more innovative companies across all three types of eco-innovation (product, process and organizational eco-innovation). The results are reported in Table 5. Thus, Hypothesis 1, which stated that more innovative companies would demonstrate higher levels of eco-innovation compared to less innovative companies, was fully supported.

In order to test the relationship between the different types of eco-innovation and firm efficiency, we continued with a linear regression analysis. In addition to testing the main relationship between ecoinnovation and firm efficiency, we also controlled for the effects of various factors that may affect firm efficiency (firm size, firm age and type of industry in which the firm operates). Linear regression analysis was conducted separately for each sub-sample, that is, for the less innovative companies (Table 6) and the more innovative companies (Table 7).

For the sub-sample of less innovative companies (Table 6), the tested model is statistically significant $(\mathrm{sig}=0.000 ; \mathrm{F}=6.803)$. Organizational eco-innovation is significantly and positively associated with firm efficiency while the other two types of eco-innovation (i.e., product and process eco-innovation) do not exert a statistically significant effect on firm efficiency. Among the control variables (firm age, firm size and type of industry), only firm age has a significant effect on firm efficiency while neither firm size nor type of industry affect firm efficiency at less innovative companies.

In the sub-sample of more innovative companies (Table 7), the model is also statistically significant (sig = $0.000 ; \mathrm{F}=12.000$ ). Results indicate a positive and significant effect of both process and organizational eco-innovation on firm efficiency. However, we do not find any significant relationship between product

\section{Table 4. Correlations, means and standard deviations of all variables}

\begin{tabular}{|c|c|c|c|c|c|c|c|}
\hline & $\begin{array}{c}\text { Product eco- } \\
\text { innovation }\end{array}$ & $\begin{array}{l}\text { Process eco- } \\
\text { innovation }\end{array}$ & $\begin{array}{l}\text { Organizational } \\
\text { eco-innovation }\end{array}$ & $\begin{array}{c}\text { Firm } \\
\text { efficiency }\end{array}$ & Firm age & Firm size & $\begin{array}{l}\text { Type of } \\
\text { industry }\end{array}$ \\
\hline Product eco-innovation & 1 & & & & & & \\
\hline Process eco-innovation & $0.737^{\star *}$ & 1 & & & & & \\
\hline Organizational eco-innovation & $0.622^{\star *}$ & $0.644^{\star *}$ & 1 & & & & \\
\hline Firm efficiency & $0.410^{\star *}$ & $0.473^{\star *}$ & $0.532^{* *}$ & 1 & & & \\
\hline Firm age & 0.128 & $0.160^{*}$ & -0.017 & $0.138^{*}$ & 1 & & \\
\hline Firm size & 0.040 & 0.091 & -0.011 & $0.201^{\star *}$ & $0.346^{* *}$ & 1 & \\
\hline Type of industry & $0.176^{* *}$ & $0.176^{* *}$ & 0.071 & $0.153^{*}$ & $0.160^{*}$ & $0.240^{\star *}$ & 1 \\
\hline Mean value & 4.61 & 5.46 & 4.34 & 3.94 & 2.63 & 1.44 & 0.41 \\
\hline Standard deviation & 1.51 & 1.38 & 1.59 & 1.53 & 0.692 & 1.067 & 0.493 \\
\hline $\begin{array}{l}\text { Notes: } \\
{ }^{*} \text { Correlation is significant at the } 0 . \\
\text { Control variable Firm age was code } \\
\text { Control variable Firm size was code } \\
\text { Control variable Type of industry w } \\
\text { Source: compiled by the authors. }\end{array}$ & $\begin{array}{l}\text { level (2-tailed); } \\
\text { as follows: } 0=3 \\
\text { as follows: } 0=\mathrm{m} \\
\text { coded as follow }\end{array}$ & $\begin{array}{l}\text { correlation is sig } \\
\text { r fewer years, } 1 \\
\text { cro company, } 1 \\
0 \text { = service-rela }\end{array}$ & $\begin{array}{l}\text { nificant at the } 0.05 \\
=4-9 \text { years, } 2=10-1 \\
=\text { small company, } 2= \\
\text { ted industry, } 1=\text { ma }\end{array}$ & $\begin{array}{l}\text { vel ( } 2 \text {-tailed). } \\
\text { years, } 3=20 \\
\text { medium-size } \\
\text { ufacturing in }\end{array}$ & $\begin{array}{l}\text { more years. } \\
\text { company, } 3= \\
\text { stry. }\end{array}$ & e company. & \\
\hline
\end{tabular}




\section{Table 5. The results of the $t$ test for the two sub-samples based on company innovativeness} (sub-groups of less innovative companies and more innovative companies)

\begin{tabular}{|c|c|c|c|c|c|}
\hline \multirow{3}{*}{ Variables } & \multicolumn{4}{|c|}{ Firm's Innovativeness Level } & \multirow{3}{*}{$t$-test } \\
\hline & \multicolumn{2}{|c|}{ Low } & \multicolumn{2}{|c|}{ High } & \\
\hline & Mean & SD & Mean & SD & \\
\hline Product eco-innovation & 4.21 & 1.57 & 4.92 & 1.39 & $-3.582^{\star *}$ \\
\hline Process eco-innovation & 5.09 & 1.45 & 5.75 & 1.25 & $-3.633^{* *}$ \\
\hline Organizational eco-innovation & 3.83 & 1.54 & 4.74 & 1.52 & $-4.407^{\star *}$ \\
\hline
\end{tabular}

eco-innovation and firm efficiency; this indicates that, similar to less innovative companies, product ecoinnovation also does not contribute to firm efficiency at more innovative companies. When controlling for the effect of various factors such as firm size, firm age and type of industry, we find that only firm size has a positive effect on firm efficiency, while firm age and type of industry do not have a significant effect.

Collectively, the results from the two regression estimations provide partial support for Hypothesis 2, as in both sub-samples some types of eco-innovation are positively associated with firm efficiency. Furthermore, the association between eco-innovation and firm efficiency is more robust in the sub-sample of more innovative companies, in that both organizational and process eco-innovations positively affect firm efficiency, whereas in the sub-sample of less innovative companies only organizational eco-innovation demonstrates a significantly positive effect.

\section{Discussion and conclusions}

Based on the empirical evidence provided above, we can conclude that more innovative companies demonstrate higher levels of eco-innovation compared to less innovative companies. This supports the dynamic capability explanation [Teece et al., 1997] which posits that more innovative companies will demonstrate higher levels of eco-innovation compared to less innovative companies because they have already developed the requisite processes for engaging in, completing, sharing, and storing the outputs from the innovative process. In addition, more innovative companies tend to be more likely to implement more complex eco-innovation types (such as process eco-innovations) and also appear to be more capable of reaping benefits from the implementation of eco-innovations. Our results indicate that at more innovative companies, two types of eco-innovation - process and organizational eco-innovation - lead to better firm efficiency, while at less innovative companies, only organizational eco-innovation contributes to firm efficiency. It is also worth noting that organizational innovation is the least complex form of eco-innovation, as it requires fewer resources (human and financial) and knowledge.

Our finding that process eco-innovation positively affects firm efficiency at more innovative companies is in line with the findings of [Triguero et al., 2013]. Furthermore, we found empirical evidence that organizational eco-innovation positively affects firm efficiency at both more and less innovative companies, which corresponds to the findings of [Chiou et al., 2011]. However, we did not find any empirical evidence to support the notion that product eco-innovation contributes to firm efficiency, for which prior research [Chiou et al., 2011] found a positive link.

In addition, when controlling for the effects of firm size, firm age and type of industry, we found that, at less innovative companies, firm age has a positive effect on firm efficiency, while at more innovative companies, it is firm size that affects firm efficiency. It appears that among less innovative companies, older companies are more efficient than younger ones. The reason for this may be that older companies have already gained

\section{Table 6. OLS Regression Estimates of the Effects on Firm Efficiency (Less Innovative} Companies)

\begin{tabular}{|c|c|c|c|c|c|}
\hline \multirow{2}{*}{ Model } & \multicolumn{2}{|c|}{$\begin{array}{c}\text { Unstandardized } \\
\text { Coefficients }\end{array}$} & \multirow{2}{*}{$\begin{array}{c}\begin{array}{c}\text { Standardized } \\
\text { Coefficients }\end{array} \\
\text { Beta }\end{array}$} & \multirow[t]{2}{*}{$t$-test } & \multirow[t]{2}{*}{ Sig. } \\
\hline & B & Std. Error & & & \\
\hline (Constant) & -0.997 & 0.323 & & -3.086 & 0.003 \\
\hline Product eco-innovation & 0.168 & 0.121 & 0.175 & 1.386 & 0.169 \\
\hline Process eco-innovation & -0.005 & 0.126 & -0.006 & -0.041 & 0.967 \\
\hline Organizational eco-innovation & 0.402 & 0.117 & 0.406 & 3.432 & $0.001^{*}$ \\
\hline Firm age & 0.312 & 0.132 & 0.231 & 2.373 & $0.020^{*}$ \\
\hline Firm size & 0.107 & 0.085 & 0.118 & 1.254 & 0.213 \\
\hline Type of industry & 0.025 & 0.229 & 0.010 & 0.108 & 0.914 \\
\hline
\end{tabular}

Notes: Dependent variable: firm efficiency, ${ }^{*} \mathrm{p}<0.05$

Source: compiled by the authors. 


\begin{tabular}{|c|c|c|c|c|c|}
\hline \multirow{2}{*}{ Model } & \multicolumn{2}{|c|}{$\begin{array}{c}\text { Unstandardized } \\
\text { Coefficients }\end{array}$} & \multirow{2}{*}{$\begin{array}{c}\begin{array}{c}\text { Standardized } \\
\text { Coefficients }\end{array} \\
\text { Beta }\end{array}$} & \multirow{2}{*}{$t$-test } & \multirow{2}{*}{ Sig. } \\
\hline & B & Std. Error & & & \\
\hline (Constant) & 0.022 & 0.295 & & 0.074 & 0.941 \\
\hline Product eco-innovation & -0.172 & 0.126 & -0.154 & -1.369 & 0.174 \\
\hline Process eco-innovation & 0.357 & 0.130 & 0.316 & 2.753 & $0.007^{\star}$ \\
\hline Organizational eco-innovation & 0.460 & 0.106 & 0.449 & 4.335 & $0.000^{*}$ \\
\hline Firm age & -0.114 & 0.112 & -0.081 & -1.015 & 0.312 \\
\hline Firm size & 0.174 & 0.074 & 0.191 & 2.359 & $0.020^{*}$ \\
\hline Type of industry & 0.074 & 0.145 & 0.038 & 0.506 & 0.614 \\
\hline
\end{tabular}

trust, market position, and a reputation on the market in addition to knowledge of how to become more efficient in their operations. Among more innovative companies, however, firm size has a positive effect on firm efficiency; that is, the larger the company, the greater the firm efficiency. In sum, less innovative companies may have learning curve economies, whereas more innovative companies may enjoy economies of scale.

Our study is not without limitations, which need to be taken into consideration when interpreting its results. First, the cross-sectional research design does not permit us to ascertain the direction of causality. Thus, our findings should be considered exploratory and be further confirmed through a longitudinal study design so as to better model the direction of causality. Second, we only have data from a single country. Still, we believe our results are generalizable to economies similar to Slovenia with regard to the level of economic development and economic structure. Third, we have subjective data on the level of innovation and efficiency. A fruitful direction for future research would be to corroborate our findings using objective data on firm innovation (including eco-innovation) and firm performance. In addition, future research should also consider and directly measure dynamic capabilities, which could work as an antecedent of the relationship between eco-innovation and firm efficiency. As such, we could precisely determine which factors contribute to the eco-innovation effect on firm efficiency. Moreover, the model could be tested by employing structural equation modeling on a larger sample in order to explore the differences between more and less innovative companies.

Limitations notwithstanding, our exploratory study has implications for both management theory and managerial practice. To start with, our study strongly suggests that more innovative companies are also more likely to implement eco-innovations. An important managerial implication from our findings is that companies should invest more in innovation and be more open to eco-innovation, for two reasons. First, eco-innovation opens up new market opportunities (through the deployment of different types of innovations) and second, eco-innovation has the potential to improve firm efficiency and, consequently, to increase a company's competitiveness. Further, we find that, at more innovative companies, both process and organizational eco-innovations lead to better firm efficiency, while at less innovative companies, only organizational eco-innovation contributes to firm efficiency. Based on these findings, we suggest that managers should invest more in innovation generally, because a more innovative company is more likely to deploy other types of innovation, such as eco-innovations in this case. This, in turn, will lead to greater firm efficiency, since eco-innovations (process and organizational eco-innovation) positively contribute to firm efficiency. Finally, with regard to management theory, future research should be oriented towards a finer-grained exploration of dynamic capabilities, which seem to represent a strong foundation for more innovative companies. Our findings imply that, when exploring the effects of eco-innovation on business performance or, in our case, on firm efficiency, we should also consider the innovativeness of the company and distinguish between more innovative and less innovative companies. More innovative companies are likely to invest more aggressively in eco-innovation and probably deploy more advanced types of ecoinnovations, which in turn has a positive effect on firm efficiency.

\section{References}

Adalikwu C. (2011) Impact of international and home-based research and development (R\&D) on innovation performance. International Journal of Human Sciences, vol. 8, no 2, pp. 474-498.

Agan Y., Acar M.F., Borodin A. (2013) Drivers of environmental processes and their impact on performance: A study of Turkish SMEs. Journal of Cleaner Production, vol. 51, pp. 23-33. DOI: 10.1016/j.jclepro.2012.12.043.

Ambec S., Lanoie P. (2008) Does It Pay to Be Green? A Systematic Overview. The Academy of Management Perspectives, vol. 22, no 4, pp. 45-62.

Barney J. (1991) Firm Resources and Sustained Competitive Advantage. Journal of Management, vol. 17, no 1, pp. 99120. DOI: $10.1177 / 014920639101700108$.

Belin J., Horbach J., Oltra V. (2011) Determinants and Specificities of Eco-innovations - An Econometric Analysis for the French and German Industry Based on the Community Innovation Survey (GREThA Discussion Paper 2011-17), Bordeaux: Université Montesquieu Bordeaux IV. Available at: http://ideas.repec.org/p/grt/wpegrt/2011-17.html, accessed 26.06.2013. 
Bourguignon D. (2016) Closing the loop: New circular economy package, Brussels: European Parliament.

Chen Y.-S. (2008) The Driver of Green Innovation and Green Image - Green Core Competence. Journal of Business Ethics, vol. 81, no 3, pp. 531-543.

Chen Y.-S. (2013) Towards green trust: The influences of green perceived quality, green perceived risk, and green satisfaction. Management Decision, vol. 51, no 1, pp. 63-82. DOI: 10.1108/00251741311291319.

Chen Y.-S., Lai S.-B., Wen C.-T. (2006) The Influence of Green Innovation Performance on Corporate Advantage in Taiwan. Journal of Business Ethics, vol. 67, no 4, pp. 331-339.

Cheng C.C., Shiu E.C. (2012) Validation of a proposed instrument for measuring eco-innovation: An implementation perspective. Technovation, vol. 32, no 6, pp. 329-344. DOI: 10.1016/j.technovation.2012.02.001.

Chiou T.-Y., Chan H.K., Lettice F., Chung S.H. (2011) The influence of greening the suppliers and green innovation on environmental performance and competitive advantage in Taiwan. Transportation Research Part E: Logistics and Transportation Review, vol. 47, no 6, pp. 822-836. DOI: 10.1016/j.tre.2011.05.016.

Dutta S., Lanvin B., Wunsch-Vincent S. (eds.) (2016) The Global Innovation Index 2016. Winning with Global Innovation, Cornell University, INSEAD, World Intellectual Property Organisation. Available at: http://www.wipo.int/edocs/ pubdocs/en/wipo_pub_gii_2016.pdf, accessed 16.05.2017.

EASAC (2015) Circular economy: A commentary from the perspectives of the natural and social sciences, Brussels: European Academies' Science Advisory Council.

Eisenhardt K.M., Martin J.A. (2000) Dynamic Capabilities: What Are They? Strategic Management Journal, vol. 21, no $10-11$, pp. $1105-1121$.

European Commission (2012) Eco-Innovation Observatory. Methodological Report, Brussels: European Commission. Available at: http://www.eco-innovation.eu/images/stories/Reports/eio_methodological_report_2012.pdf, accessed 26.06.2014.

Ghisellini P., Cialani C., Ulgiati S. (2016) A review on circular economy: The expected transition to a balanced interplay of environmental and economic systems. Journal of Cleaner Production, vol. 114, pp. 11-32. DOI: 10.1016/j. jclepro.2015.09.007.

Govindan K., Diabat A. Madan Shankar K. (2014) Analyzing the drivers of green manufacturing with fuzzy approach. Journal of Cleaner Production, vol. 96, no 1, pp. 182-193. DOI: 10.1016/j.jclepro.2014.02.054.

Hojnik J., Ruzzier M. (2016a) What drives eco-innovation? A review of an emerging literature. Environmental Innovation and Societal Transitions, vol. 19, pp. 31-41. DOI: http://dx.doi.org/10.1016/j.eist.2015.09.006.

Hojnik J., Ruzzier M. (2016) The driving forces of process eco-innovation and its impact on performance: Insights from Slovenia. Journal of Cleaner Production, vol. 133, pp. 812-825. DOI: 10.1016/j.jclepro.2016.06.002.

Horbach J. (2008) Determinants of environmental innovation - New evidence from German panel data sources. Research Policy, vol. 37, no 1, pp. 163-173. DOI: 10.1016/j.respol.2007.08.006.

Horbach J., Rammer C., Rennings K. (2012) Determinants of eco-innovations by type of environmental impact The role of regulatory push/pull, technology push and market pull. Ecological Economics, vol. 78, pp. 112-122. DOI: 10.1016/j.ecolecon.2012.04.005.

Kammerer D. (2009) The effects of customer benefit and regulation on environmental product innovation. Ecological Economics, vol. 68, no 8-9, pp. 2285-2295. DOI: 10.1016/j.ecolecon.2009.02.016.

Kesidou E., Demirel P. (2012) On the drivers of eco-innovations: Empirical evidence from the UK. Research Policy, vol. 41, no 5, pp. 862-870. DOI: 10.1016/j.respol.2012.01.005.

Klewitz J. (2012) Intermediaries driving eco-innovation in SMEs: A qualitative investigation. European Journal of Innovation Management, vol. 15, no 4, pp. 442-467. DOI: 10.1108/14601061211272376.

Li D., Liu J. (2014) Dynamic capabilities, environmental dynamism, and competitive advantage: Evidence from China. Journal of Business Research, vol. 67, no 1, pp. 2793-2799. DOI: 10.1016/j.jbusres.2012.08.007.

Li Y. (2014) Environmental innovation practices and performance: Moderating effect of resource commitment. Journal of Cleaner Production, vol. 66, pp. 450-458. DOI: 10.1016/j.jclepro.2013.11.044.

Makkonen H., Pohjola M., Olkkonen R., Koponen A. (2014) Dynamic capabilities and firm performance in a financial crisis. Journal of Business Research, vol. 67, no 1, pp. 2707-2719. DOI: 10.1016/j.jbusres.2013.03.020.

Montabon F., Sroufe R., Narasimhan R. (2007) An examination of corporate reporting, environmental management practices and firm performance. Journal of Operations Management, vol. 25, no 5, pp. 998-1014. DOI: 10.1016/j. jom.2006.10.003.

Nelson R.R., Winter S.G. (1982) An Evolutionary Theory of Economic Change, Cambridge, MA: Harvard University Press.

Ness D. (2008) Sustainable urban infrastructure in China: Towards a factor 10 improvement in resource productivity through integrated infrastructure system. International Journal of Sustainable Development and World Ecology, vol. 15, no 4, pp. 288-301.

O’Brien R.M. (2007) A caution regarding rules of thumb for variance inflation factors. Quality and Quantity, vol. 41, no 5, pp. 673-690. DOI: 10.1007/s11135-006-9018-6.

Piening E.P., Salge T.O. (2015) Understanding the Antecedents, Contingencies, and Performance Implications of Process Innovation: A Dynamic Capabilities Perspective. Journal of Product Innovation Management, vol. 32, no 1, pp. 80-97. DOI: $10.1111 /$ jpim.12225.

Sarkar A.N. (2013) Promotion of eco-innovation to leverage sustainable development of eco-industry and green growth. International Journal of Ecology and Development, vol. 25, no 2, pp. 71-104. Available at: http://www.ecsdev.org/ojs/ index.php/ejsd/article/view/48, accessed 12.06.2017.

Sharma S., Vredenburg H. (1998) Proactive corporate environmental strategy and the development of competitively valuable organizational capabilities. Strategic Management Journal, vol. 19, pp. 729-753.

Shrivastava P. (1995) Environmental technologies and competitive advantage. Strategic Management Journal, vol. 16, no S1, pp. 183-200. Available at: http://onlinelibrary.wiley.com/doi/10.1002/smj.4250160923/abstract, accessed 23.02.2014.

Su B., Heshmati A., Geng Y., Yu X. (2013) A review of the circular economy in China: Moving from rethoric to implementation. Journal of Cleaner Production, vol. 42, pp. 215-277.

Teece D.J. (1981) The market for know-how and the efficient international transfer of technology. Annals of the Academy of Political and Social Science, vol. 458, pp. 81-96.

Teece D.J., Pisano G., Shuen A. (1997) Dynamic capabilities and strategic management. Strategic Management Journal, vol. 18, no 7, pp. 509-533. DOI: 10.1142/9789812834478_0002.

Triguero A., Moreno-Mondéjar L., Davia M.A. (2013) Drivers of different types of eco-innovation in European SMEs. Ecological Economics, vol. 92, pp. 25-33. DOI: 10.1016/j.ecolecon.2013.04.009.

Wernerfelt B. (1984) A resource-based view of the firm. Strategic Management Journal, vol. 5, no 2, pp. 171-180.

World Economic Forum (2016) Stages of development and the weighted index. Available at: http://reports.weforum. org/global-competitiveness-report-2014-2015/methodology, accessed 17.01.2017. 

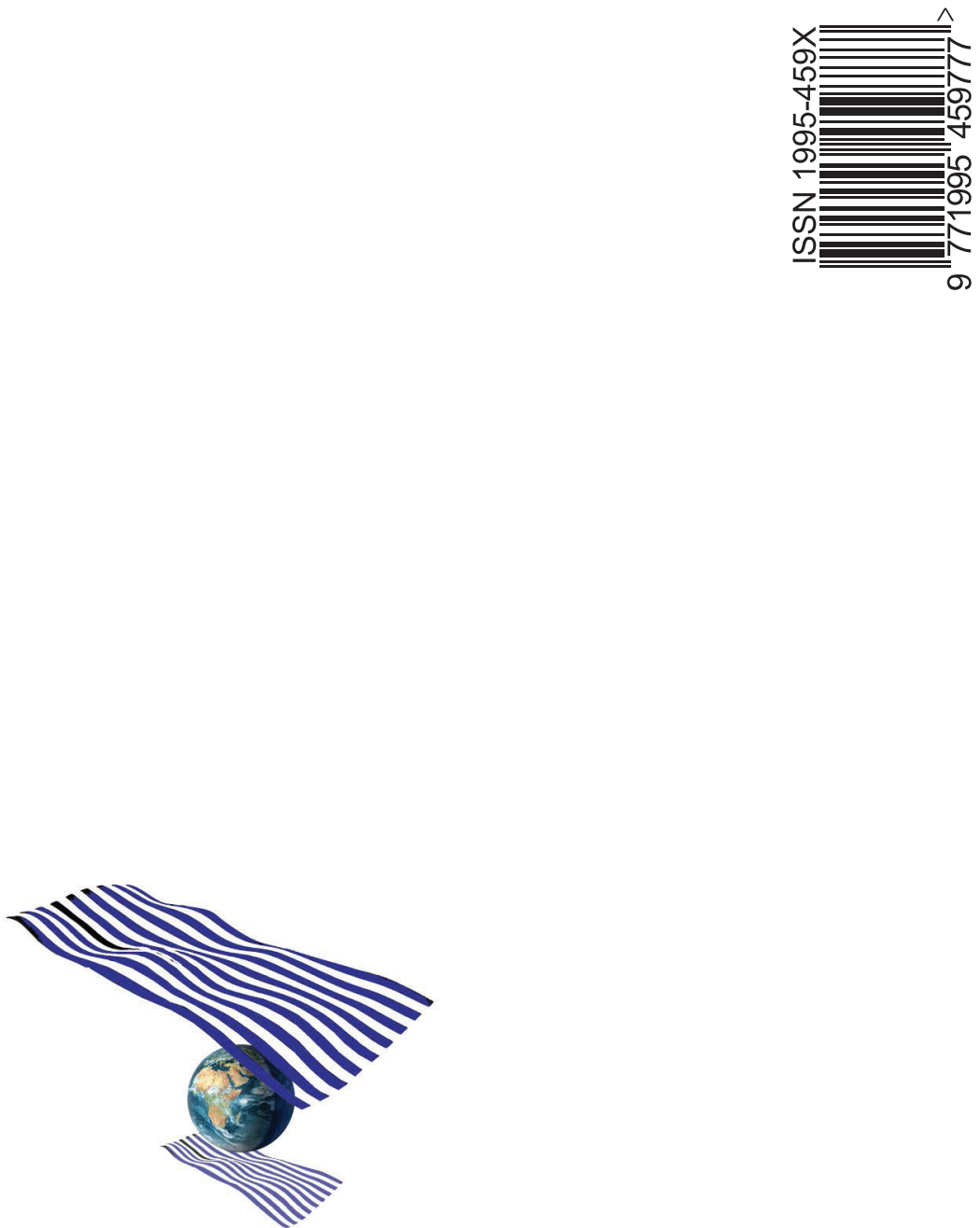